\title{
A High Efficiency PSOFC/ATS-Gas Turbine Power System
}

\section{Final Report}

\author{
Contract Start Date: 29 May 1998 \\ Contract End Date: 28 February 2001
}
W. L. Lundberg
Principal Authors:
G. A. Israelson
R. A. Holmes
J. E. King
M. D. Moeckel (Caterpillar Inc.)
S. E. Veyo, Project Manager

February, 2001

\section{Contract No. DE-AC26-98FT40455}

by

Siemens Westinghouse Power Corporation Stationary Fuel Cells 1310 Beulah Road Pittsburgh, PA 15235-5098 and under subcontract Caterpillar Inc. Technical Center, Bldg. F 14009 Old Galena Road Mossville, IL 61552

for

\author{
U. S. Department of Energy \\ National Energy Technology Laboratory \\ P.O. Box 10940, MS 921-143 \\ Pittsburgh, PA 15236-0944
}

This report was written with support of the U.S. Department of Energy under Contract No. DE-AC26-98FT40455. The Government reserves for itself, and others acting on its behalf, a royalty-free, nonexclusive, irrevocable, worldwide license for Government purposes to publish, distribute, translate, duplicate, exhibit and perform this copyrighted report. 
"This report was prepared as an account of work sponsored by an agency of the United States Government. Neither the United States Government nor any agency thereof, nor any of their employees, makes any warranty, express or implied, or assumes any legal liability or responsibility, for the accuracy, completeness, or usefulness of any information, apparatus, product, or process disclosed, or represents that its use would not infringe privately owned rights. Reference herein to any specific commercial product, process, or service by trade name, trademark, manufacturer, or otherwise does not necessarily constitute or imply its endorsement, recommendation, or favoring by the United States Government or any agency thereof. The views and opinions of authors expressed herein do not necessarily state or reflect those of the United States Government of any agency thereof." 


\begin{abstract}
A study is described in which the conceptual design of a hybrid power system integrating a pressurized Siemens Westinghouse solid oxide fuel cell generator and the Mercury $^{\mathrm{TM}} 50$ gas turbine was developed. The Mercury ${ }^{\mathrm{TM}} 50$ was designed by Solar Turbines as part of the U.S. Department of Energy Advanced Turbine Systems program. The focus of the study was to develop the hybrid power system concept that principally would exhibit an attractively-low cost of electricity (COE). The inherently-high efficiency of the hybrid cycle contributes directly to achieving this objective, and by employing the efficient, power-intensive Mercury ${ }^{\top M} 50$, with its relatively-low installed cost, the higher-cost SOFC generator can be optimally sized such that the minimum-COE objective is achieved. The system cycle is described, major system components are specified, the system installed cost and COE are estimated, and the physical arrangement of the major system components is discussed. Estimates of system power output, efficiency, and emissions at the system design point are also presented. In addition, two bottoming cycle options are described, and estimates of their effects on overall-system performance, cost, and COE are provided.
\end{abstract}




\section{TABLE OF CONTENTS}

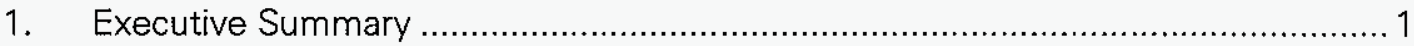

1.1 Power System Design Description …………………………………………….. 1

1.2 Power System Performance Estimates ........................................................... 4

1.3 System Cost and Economics ...................................................................... 4

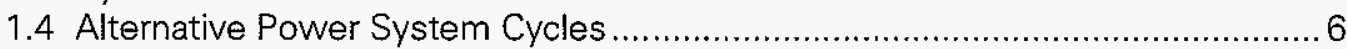

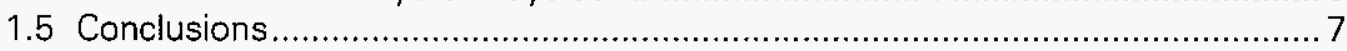

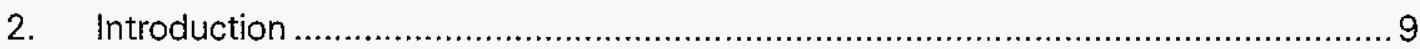

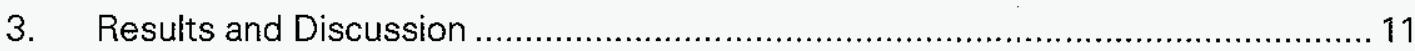

3.1 Power Plant Conceptual Design ...................................................................... 11

3.1.1 Design Requirements and Objectives ................................................. 11

3.1.2 Cycle and Power System Description.................................................... 14

3.1.3 Power System Performance Analysis................................................... 18

3.1.4 Power Plant and Site Arrangement ………………………………....... 24

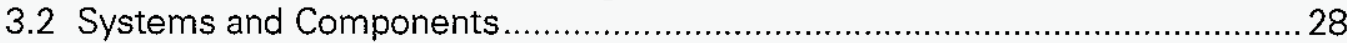

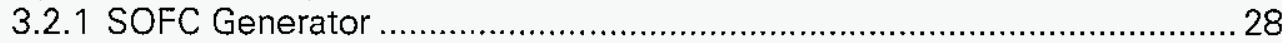

3.2.2 Gas Turbine System - Caterpillar Solar Turbines Mercury ${ }^{\top M} 50 \ldots \ldots \ldots \ldots . .52$

3.2.3 SOFC Power Conditioning System ................................................... 78

3.2.4 Instrumentation and Controls System ..................................................96

3.2.5 Electrical Distribution System (EDS) ..................................................... 97

3.2.6 Fuel Processing System ................................................................... 99

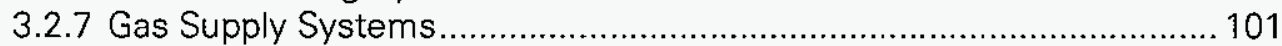

3.2.8 Balance of Plant (BOP) Equipment .................................................. 103

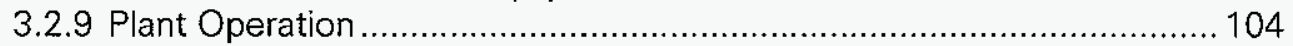

3.3 Power System Installed Cost and Cost of Electricity Estimates ......................110

3.4 Conceptual Design Trade-Off Studies .......................................................... 114

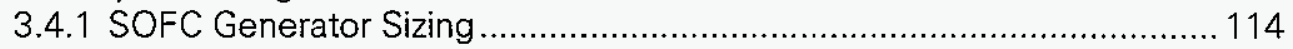

3.4.2 Steam Turbine Bottoming Cycle Option ................................................ 117

3.4.3 Advanced Ammonia-Water Power Cycle for the PSOFC/GT Hybrid

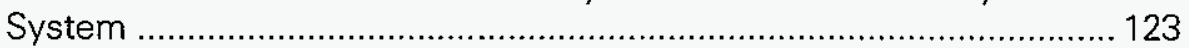

3.4.4 Effect of Power System Type on Emissions ........................................ 135

3.4.5 Power System Arrangement Studies .................................................. 137

3.4.6 Desulfurization System Cost Study ………...................................... 144

3.4.7 Cover Gas System Cost Study ...................................................... 145

3.4.8 Hydrogen Gas Generation Cost Study ............................................. 148

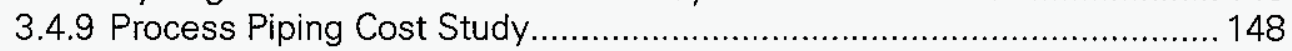

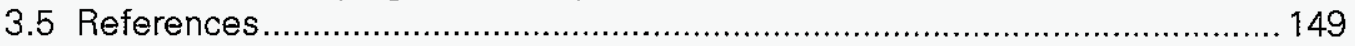

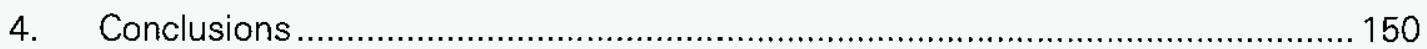

Appendix A: The Effect of Staging on Efficiency of Isothermal SOFC Stacks 


\section{LIST OF FIGURES}

Figure 1-1 — Simplified PSOFC/ATS-GT hybrid power system cycle. ............................. 2

Figure 1-2 - 20 MWe PSOFC/ATS-GT power system site arrangement. ......................... 3

Figure 1-3 _ Effect of fuel cost on COE estimates. .................................................... 6

Figure 2-1 - Simplied atmospheric pressure SOFC power system cycle ...................... 9

Figure 2-2 - Simplified PSOFC/GT hybrid power system cycle .................................. 10

Figure 3-1 — Simplified PSOFC/ATS-GT hybrid power system cycle. ........................... 15

Figure 3-2 - 20 MWe PSOFC/ATS-GT power system site arrangement. ..................... 17

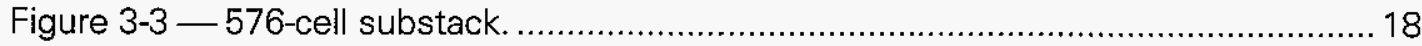

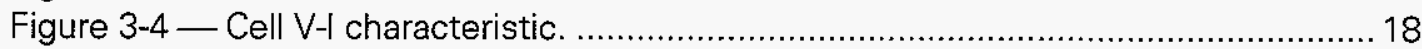

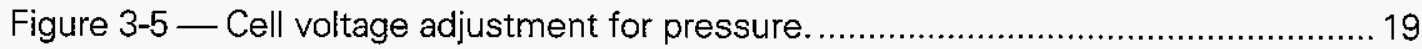

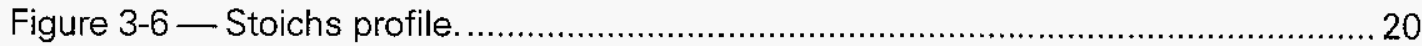

Figure 3-7 — Power block statepoint diagram. ......................................................... 22

Figure 3-8 - 20 MW PSOFC/ATS-GT power system arrangement ..............................2 25

Figure 3-9 - 20 MWe PSOFC/ATS-GT power system site arrangement - plan view. . 26

Figure 3-10 - PSOFC/ATS-GT hybrid simplified process diagram. .............................. 29

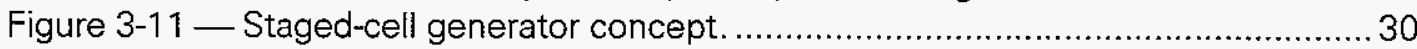

Figure 3-12 - Temperature profiles in staged-cell generator. ..................................... 33

Figure 3-13 - Cell voltage and average temperature in a staged-cell generator. .............34 34

Figure 3-14 — Fuel mole fraction distribution in a staged-cell generator. ........................ 35

Figure 3-15 — Fuel concentration at the exit of each group of cells. ............................ 37

Figure 3-16 - Nickel fuel electrode oxidation limit - cross flow stack at FU $=92 \% \ldots . .37$

Figure 3-17 — Schematic fuel cell array..................................................................... 39

Figure $3-18$ - Ten substacks isometric view. ....................................................... 40

Figure 3-19 — Exploded view of 576-cell SOFC substack. .................................... 42

Figure 3-20 — Substack fuel distribution system...................................................... 43

Figure 3-21 — Pressure vessel isometric views. .................................................... 47

Figure 3-22 — PSOFC generator module isometric view. ....................................... 48

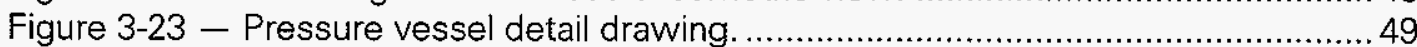

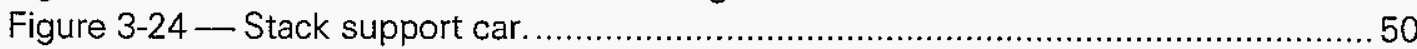

Figure 3-25 — Isometric view of module with internal components.............................51

Figure 3-26 - Mercury ${ }^{\mathrm{TM}} 50$ recuperated gas turbine, pictorial view.......................... 53

Figure $3-27$ - Mercury ${ }^{\mathrm{TM}} 50$ recuperated gas turbine, plan and elevation views...............53

Figure 3-28 - Mercury ${ }^{\mathrm{TM}} 50$ turnkey system test at solar turbines, San Diego, CA .......54

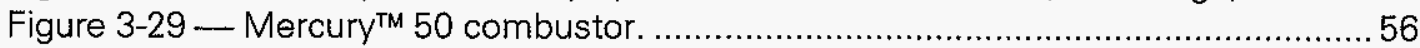

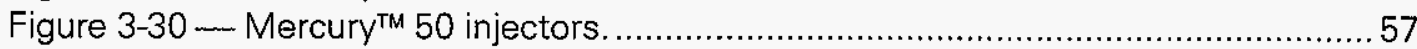

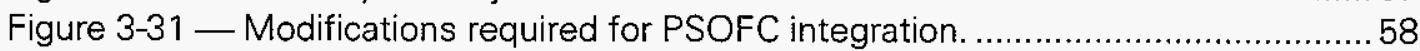

Figure 3-32 - Comparison of simple and recuperated cycles...................................63

Figure 3-33 - Construction of the primary surface recuperator (PSR) .......................64

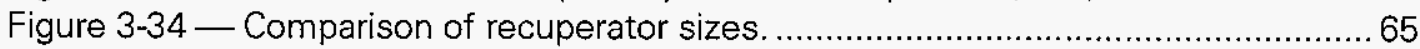

Figure 3-35 — Advanced component efficiency compressor.......................................6 66

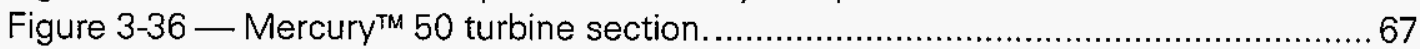

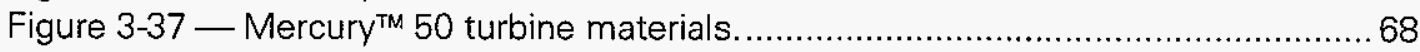

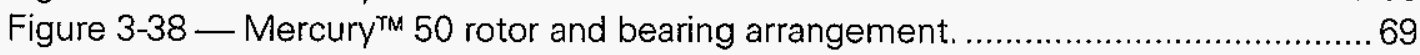

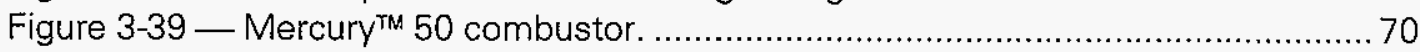

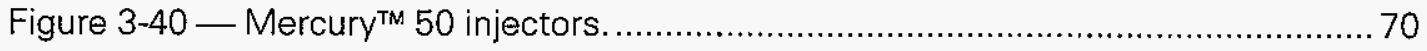


Figure $3-41$ - Parasitic losses in a gas turbine package ............................................. 74

Figure 3-42 - Mercury ${ }^{\mathrm{TM}} 50$ core gas turbine and recuperator flow path....................... 75

Figure 3-43 - Modular arrangement of Mercury ${ }^{\mathrm{TM}} 50$ advanced turbine system........... 76

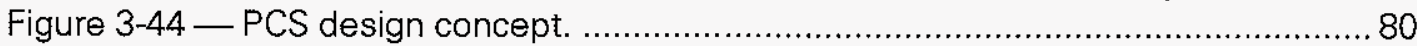

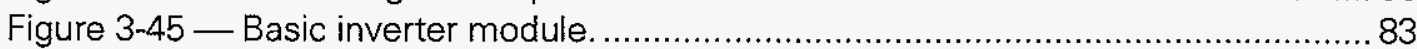

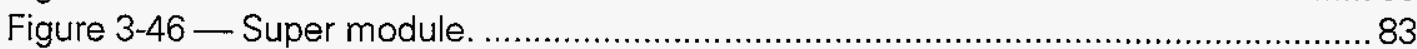

Figure 3-47 — One-line diagram for power conditioning system associated with four PSOFC modules.

Figure 3-48 - One-line diagram for power conditioning system associated with eight

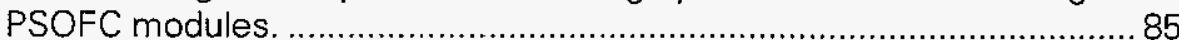

Figure $3-49$ - Power conditioning concept for four PSOFC modules. .......................... 89

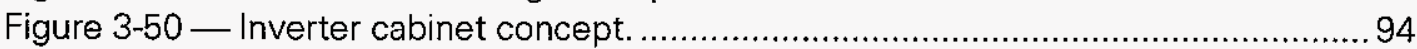

Figure 3-51 — PCS cabinet concept for four PSOFC generator modules. ...................... 95

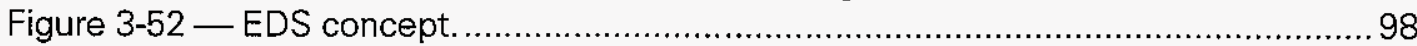

Figure 3-53 — Effect of fuel cost on COE estimates............................................. 110

Figure 3-54 — Simplified PSOFC/ATS-GT hybrid power system cycle. …................... 115

Figure 3-55 - Effect of PSOFC generator sizing on system performance and COE ... 117

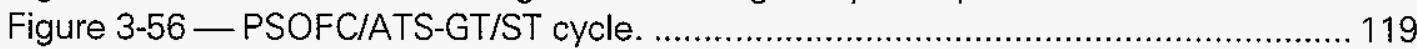

Figure 3-57 - COE estimates for the PSOFC/ATS-GT/ST power system. ..................... 121

Figure 3-58 — Flow schematic of the ammonia-water power cycle............................ 126

Figure 3-59 - COE estimates for the PSOFC/ATS-GT/ammonia-water power

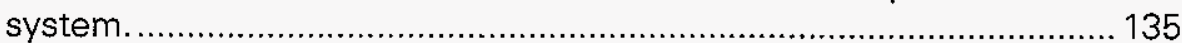

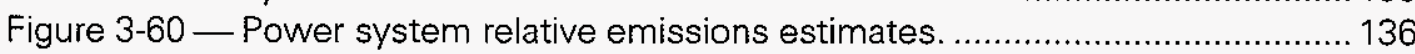

Figure 3-61 — Alternative 1 system arrangement — isometric view.......................... 137

Figure 3-62 — Alternative 1 system arrangement — plan view................................ 138

Figure 3-63 — Alternative 2 system arrangement — isometric view.......................... 139

Figure 3-64 — Alternative 2 system arrangement — plan view.............................. 140

Figure 3-65 — Alternative 3 system arrangement — isometric view......................... 141

Figure 3-66 — Alternative 3 system arrangement — plan view................................ 142 


\section{LIST OF TABLES}

Table 1.1 - PSOFC/ATS-GT System Installed Cost Summary ........................................ 5

Table 1.2 - Economic Analysis Summary of Results .................................................... 5

Table 3.1 — Power Block Design-Point Performance Estimates ................................... 21

Table 3.2 — Power System Design-Point Performance Estimates ............................... 21

Table 3.3 — Power Block Statepoint Parameter Estimates .......................................... 23

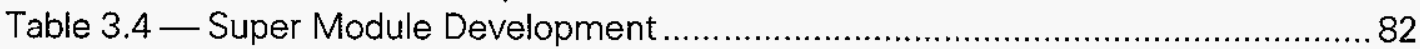

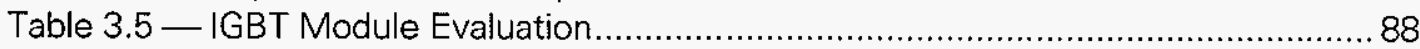

Table 3.6 — Plant Emergency Situations ............................................................... 109

Table 3.7 — Power System Installed-Cost Estimate *.............................................. 111

Table 3.8 - Power System Cost of Electricity Estimate ........................................... 112

Table 3.9 - Conventional-Technology Power System Cost of Electricity Estimate...... 113

Table 3.10 — Steam Turbine System Design-Point Parameter Values ......................... 119

Table 3.11 — PSOFC/ATS-GT/ST Power System Design-Point Performance Estimates

Table 3.12 - Power System Installed-Cost Estimate (PSOFC/ATS-GT/ST Power System)

Table 3.13 - Power System Cost of Electricity Estimate (PSOFC/ATS-GT/ST Power System).

Table 3.14 — Energy Flows in the Ammonia-Water Power Cycle ............................... 128

Table 3.15 — State Points for the Ammonia-Water Power Cycle ................................ 129

Table 3.16 _. Installed Cost for the Ammonia-Water Power Cycle............................... 130

Table 3.17 - PSOFC/ATS-GT/Ammonia-Water Power System Design-Point Performance Estimates.

Table 3.18 - Power System Installed-Cost Estimate (PSOFC/ATS-GT/Ammonia-Water Power System).

Table 3.19 - Power System Cost-of-Electricity Estimate (PSOFC/ATS-GT/AmmoniaWater Power System) .................................................................. 134

Table 3.20 — Nitrogen Generator/Compressor Characteristics .................................. 147

Table 3.21 - Costs for Options Investigated for Supply of Nitrogen System .............. 148

Table 3.22 — Hydrogen Generator Characteristics ....................................................... 148

Table 3.23 — High Temperature Piping ${ }^{(1)}$ Costs..................................................... 149 


\section{EXECUTIVE SUMMARY}

\subsection{Power System Design Description}

The objective of this project was the development of a 20 MWe-class, highly-efficient (net $A C / L H V>60 \%$ ), hybrid cycle (fuel cell plus gas turbine) power system concept that would take advantage of gas turbine technology developed under the U.S. Department of Energy Advanced Turbine Systems (ATS) program and achieve an attractively-low cost of electricity (COE) relative to the COE for conventional-technology gas turbine combined cycle power systems. The power system devised is based on a hybrid cycle that integrates a pressurized Siemens Westinghouse tubular solid oxide fuel cell (PSOFC) generator with a fired Solar Turbines Mercury ${ }^{\text {TM }} 50$ gas turbine. Due to its application of advanced turbine technology, and to recuperation, the Mercury ${ }^{\top M} 50$ achieves a Brayton cycle efficiency of $41 \%$ to $42 \%$ (GT AC/LHV). The nominal GT AC power output is $4.5 \mathrm{MWe}\left[15^{\circ} \mathrm{C}\left(59^{\circ} \mathrm{F}\right)\right.$ ambient-air temperature]. The premise of the study was that applying the efficient, power-intensive Mercury ${ }^{\top M} 50$, fired to its design turbine inlet temperature $(\mathrm{TIT})$, in the hybrid cycle power system would minimize the required number of relatively high cost SOFC stacks needed to achieve a total system power output of roughly $20 \mathrm{MWe}$, resulting thereby in a system that would operate with a very low COE.

Operating at atmospheric pressure, the efficiency horizon for an SOFC generator is $45 \%$ to $50 \%$ (net AC/LHV), while a Mercury ${ }^{\mathrm{TM}} 50$-class gas turbine, operating at its design point, will convert to electric power over $40 \%$ of the heat supplied to the gas turbine cycle. When a PSOFC generator and the gas turbine are integrated in a power system, a system efficiency near $60 \%$ can be achieved. This is due to the processing to power of SOFC exhaust heat by the gas turbine, the attendant reduction in the rate at which fuel is needed by the gas turbine combustor, and to the enhanced operation of the SOFC generator at elevated pressure.

The low-COE PSOFC/ATS-GT system concept developed by Siemens Westinghouse is based on the cycle depicted in Figure 1-1. The gas turbine/generator and recuperator are components in the Mercury ${ }^{\mathrm{TM}} 50$ package, and the SOFC generator consists of an array of fuel cell stacks housed in horizontal cylindrical pressure vessels. The PSOFC generator produces DC power that is converted by the power conditioning system (PCS) to $A C$ form suitable for export to the utility AC grid. The PCS is instrumental in the 
achievement of high hybrid cycle efficiencies, and continuing work is needed to develop affordable power conditioning systems with DC-to-AC efficiencies in excess of $95 \%$.

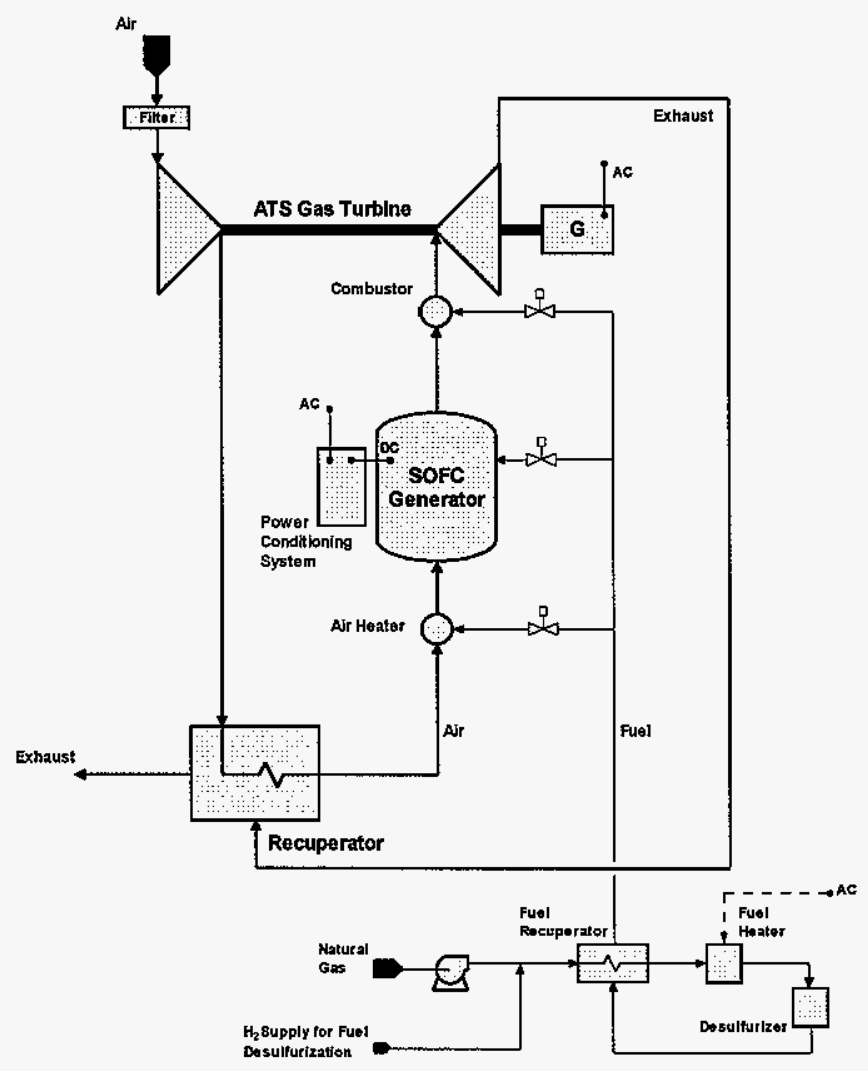

Figure 1-1 - Simplified PSOFC/ATS-GT hybrid power system cycle.

Figure 1-1 provides detail on the fuel desulfurization system. The power system fuel, pipeline natural gas, can contain sulfur-bearing compounds, occurring naturally, or added for leak-detection purposes, that must be reduced in concentration to preclude a sulfur reaction with fuel cell nickel components. In the power system concept, a lowmaintenance fuel desulfurizer is employed in which sulfur is reacted to hydrogen sulfide in a cobalt-molybdenum catalyst bed, and the resulting $\mathrm{H}_{2} \mathrm{~S}$ is adsorbed by heated zinc oxide.

An isometric view of a $20 \mathrm{MWe-class} \mathrm{PSOFC/ATS-GT} \mathrm{power} \mathrm{system} \mathrm{is} \mathrm{presented} \mathrm{in}$ Figure 1-2. It is composed of two power blocks, each consisting of a single Mercury $^{\mathrm{TM}} 50$ gas turbine and an SOFC generator composed of four SOFC modules that are 
In the PSOFC generator design, the flows of air and reformed-fuel on the cathode and anode of each fuel cell occur cocurrently and parallel to the cell axis. This is the conventional configuration that has been used by Siemens Westinghouse in all demonstration SOFC generators designed and operated to date. It was selected for application in the PSOFC/ATS-GT system concept after an extensive analytical evaluation of the stagedcell SOFC generator concept. The staged-cell design, which retained the conventional air delivery design on the cell cathode side, but employs crossflow on the fuel (anode) side, was originally believed to offer the possibility of operating the SOFC generator at high fuel utilizations, thereby contributing to the achievement of higher generator and system efficiencies. Based upon analysis, the potential benefits of staging proved elusive for two major reasons. First, since the first cell stage is fed relatively cold fuel, the first few cell stages operate at substantially less than optimum temperature for yttriastabilized zirconia electrolyte cells. Second, the last cell stage can not be operated at fuel utilization greater than that for the cocurrent stack because the approximately parabolic axial temperature distribution and concomitant non-uniform current density distribution place the cell hot spot at hazard for anode oxidation at roughly the same average fuel utilization achievable in a non-staged cell stack.

\subsection{Power System Performance Estimates}

The power system is intended for baseloaded design-point operation. At that point, the system, consisting of the two power blocks, produces 24.7 MWe net AC power with an efficiency of $59.9 \%$ (net AC/LHV). Approximately $16 \mathrm{MWe}$ are derived from the SOFC generator modules, and the remainder from the two gas turbines. Thus, the ratio of SOFC-derived power to ATS GT power is approximately 2:1. The estimated rates of $\mathrm{CO}_{2}$ and NOx emission at the system design point are $340 \mathrm{~kg} / \mathrm{MWh}$ and $0.04 \mathrm{~kg} / \mathrm{MWh}(5$ ppmv), respectively; the exhaust flow rate and temperature are $34 \mathrm{~kg} / \mathrm{s}$ and $360^{\circ} \mathrm{C}$.

\subsection{System Cost and Economics}

The system installed-cost estimate is $\$ 1170 / \mathrm{kWe}$. It includes costs related to site preparation, equipment procurement, shipping, and installation, as well as allowances for $\mathrm{G} \& \mathrm{~A}$, sales and marketing, and profit. Mature technologies and products were as- 
sumed. The distribution of the power system installed cost is indicated in Table 1.1, where values are referenced to the total power system capacity.

Table 1.1 - PSOFC/ATS-GT System Installed Cost Summary

\begin{tabular}{|c|c|}
\hline & Cost, $\$ / \mathbf{k W e}$ \\
\hline SOFC Generator Equipment & 334 \\
\hline SOFC Power Conditioning Equipment & 147 \\
\hline Gas Turbine Generator Equipment & 200 \\
\hline Balance of Plant Equipment & 178 \\
\hline Subtotal & 859 \\
\hline Site Preparation & 17 \\
\hline Project Management and Engineering & 37 \\
\hline Overhead and Profit Allowance & 241 \\
\hline Subtotal & 295 \\
\hline Total Plant Cost & 1154 \\
\hline Spare Parts, Startup, and Land Allowance & 17 \\
\hline Total Capital Requirement & 1171 \\
\hline
\end{tabular}

COE estimates have been developed for the PSOFC/ATS-GT system, operating at its design point, and also for a competing technology, which was assumed to be $20 \mathrm{MWe}-$ class gas turbine combined cycle power system. Table 1.2 summarizes input used in the COE analysis, and also the results.

Table 1.2 - Economic Analysis Summary of Results

\begin{tabular}{|c|c|c|}
\hline & $\begin{array}{l}\text { PSOFC/ATS-GT } \\
\text { Power System }\end{array}$ & $\begin{array}{c}\text { Conventional-Technology Power } \\
\text { System } \\
\text { (Gas Turbine/Steam Turbine } \\
\text { Combined Cycle)* }\end{array}$ \\
\hline No. of round-the-clock operators & 1 & 1 \\
\hline No. systems in operation & 5 & 5 \\
\hline Labor cost components & $\begin{array}{l}\text { System operation \& house- } \\
\text { keeping maintenance }\end{array}$ & $\begin{array}{l}\text { System operation \& housekeeping } \\
\text { maintenance }\end{array}$ \\
\hline SOFC replacement & $\$ 0.0014 /$ system kWh & \\
\hline $\begin{array}{l}\text { Gas turbine/steam turbine system } \\
\text { maintenance }\end{array}$ & $\$ 0.004 / \mathrm{GT}$ kWh & $\$ 0.007 /$ system kWh \\
\hline Power system capacity factor & 0.92 & 0.92 \\
\hline Capital charge rate & $15 \%$ & $15 \%$ \\
\hline Fuel cost & \$3/MMBtu & $\$ 3 / \mathrm{MMBtu}$ \\
\hline Power system capital cost & $\$ 28.9 \mathrm{M}(\$ 1170 / \mathrm{kWe})$ & $\$ 14.9 \mathrm{M}(\$ 830 / \mathrm{kWe})$ \\
\hline Power Output & $24.7 \mathrm{MWe}$ & $17.9 \mathrm{MWe}$ \\
\hline $\begin{array}{l}\text { Emissions estimates } \\
\mathrm{CO}_{2} \\
\mathrm{NOx} \\
\text { Sox }\end{array}$ & $\begin{array}{l}340 \mathrm{~kg} / \mathrm{MWh} \\
0.04 \mathrm{~kg} / \mathrm{MWh}(5 \mathrm{ppmv}) \\
0\end{array}$ & $\begin{array}{l}420 \mathrm{~kg} / \mathrm{MWh} \\
0.380 \mathrm{~kg} / \mathrm{MWh} \text { ( } 25 \mathrm{ppmv}) \\
2.5 \mathrm{~g} / \mathrm{MWh} \text { ( } 4 \text { ppmv sulfur in fuel) }\end{array}$ \\
\hline $\begin{array}{l}\text { Power system efficiency (net } \\
\text { AC/LHV), \% }\end{array}$ & 59.9 & 47.9 \\
\hline Cost of electricity, mills/kWh & 44.8 & 47.6 \\
\hline
\end{tabular}

* Information Source: Gas Turbine World 1997 Handbook, turnkey power generation projects, p. 24. 
The projected COE for the PSOFC/ATS-GT power system is approximately $6 \%$ less than the conventional-technology COE at the baseline $\$ 3$ fuel cost. However, as Figure 1-3 indicates, the COE advantage of the advanced power system is expected to increase with increasing fuel cost. For example, at $\$ 6$ its estimated COE is nearly $11 \%$ less than the projected conventional-technology value.

As a task in this study, a conceptual design was developed for the SOFC power conditioning system. The estimated efficiency (DC-to-grid $\mathrm{AC}$ ) and mature-technology cost of the resulting PCS design were 95\% and \$220/DC kWe, and these values are inherent in the overall performance and cost projections presented above. The PCS efficiency is instrumental in determining the overall power system efficiency. For example, a onepoint increase in PCS efficiency would increase the PSOFC/ATS-GT system efficiency by approximately $6 / 10$ of one percentage point. Additional study is needed to determine if a PCS efficiency above $95 \%$ could be achieved cost-effectively.

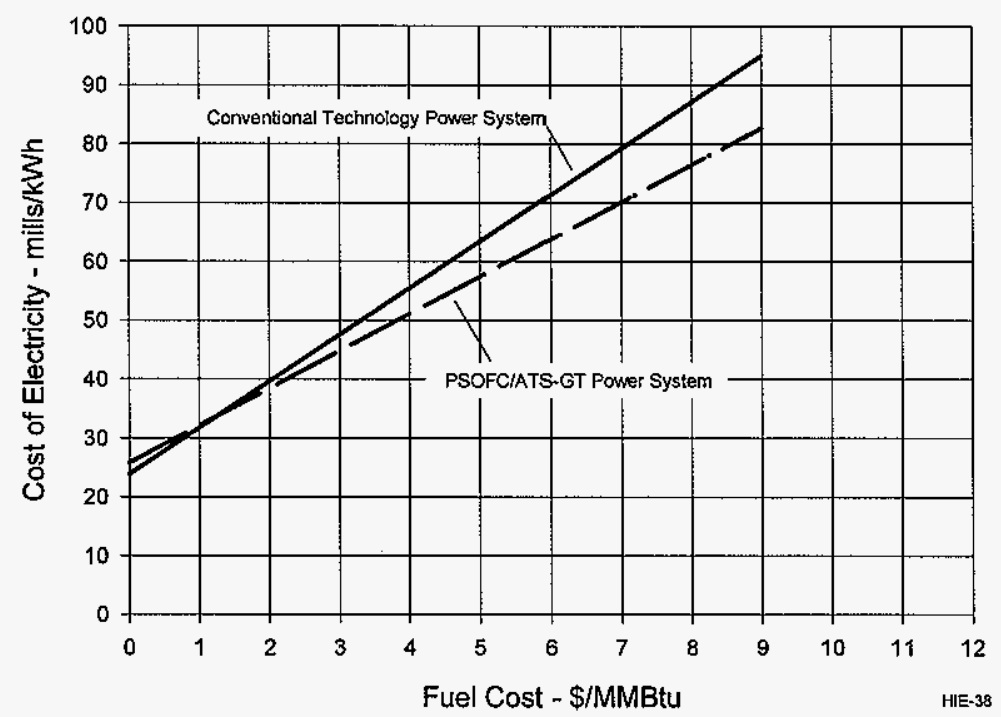

Figure 1-3 - Effect of fuel cost on COE estimates.

\subsection{Alternative Power System Cycles}

Two options were evaluated for using heat recovered from the combined exhaust of two $10 \mathrm{MWe}$-class PSOFC/ATS-GT power blocks to generate additional electric power. In one, a once-through heat recovery steam generator and steam turbine cycle were ap- 
plied. An additional 1.5 MWe were produced, increasing the total power output and efficiency to $26.2 \mathrm{MWe}$ and $63.6 \%$. In the second option, the bottoming cycle was based on an ammonia-water power system concept developed by the Energy Concepts Company of Annapolis, Maryland. In this case the system power boost was $1.9 \mathrm{MWe}$, which increased system power output and efficiency to $26.5 \mathrm{MWe}$ and $64.4 \%$. However, an economic analysis of each option indicates there may be little COE advantage relative to the baseline PSOFCIATS-GT power system because the positive COE effects produced by the increased power output and efficiency are countered by the increased power system installed and O\&M costs. Note, however, that the COE evaluations did not consider emission taxes, and adding bottoming cycles to the baseline PSOFCIATS-GT power systems would likely gain economic attractiveness where such taxes were levied.

\subsection{Conclusions}

- A low-cost, highly-efficient (60\%) 20 MWe-class PSOFC/ATS-GT hybrid power system concept has been devised that employs the 4.5 MWe Solar Turbines Mercury ${ }^{\mathrm{TM}}$ 50 gas turbine that was developed under the DOE ATS program. The projected hybrid cycle power system COE is $44.8 \mathrm{mills} / \mathrm{kWh}$, which is $6 \%$ less than the estimated COE for a conventional $20 \mathrm{MW}$-class gas turbine combined cycle power system. These estimates apply to a fuel cost of $\$ 3 / \mathrm{MMBtu}$. Due to its higher operating efficiency, the PSOFC/ATS-GT power system would have increased COE advantage at higher fuel costs.

- The PSOFC/ATS-GT power system efficiency estimate is $59.9 \%$ (net AC/LHV), twelve points higher than that achieved by the conventional-technology gas turbine combined cycle power system. This estimate is based upon mature-product cell V-I characteristics that are expected to be available in the 2005 to 2010 time period, and upon current Mercury ${ }^{\top \mathrm{M}} 50$ performance.

- An SOFC PCS concept was developed that has an estimated DC-to-grid AC conversion efficiency of $95 \%$ and an installed cost of approximately $\$ 220 / \mathrm{DC} \mathrm{kWe}$.

- By equipping the PSOFC/ATS-GT power system with a bottoming cycle (steam turbine or ammonia-water), the overall system power output and efficiency will increase. However, due to the accompanying increases in system installed and O\&M costs, the gains in power output and efficiency do not necessarily translate to significant $\mathrm{COE}$ reductions. It is likely that the economic attractiveness of adding a bottoming cycle to the baseline PSOFC/ATS-GT power system would increase if taxes on power system emissions were levied.

- The staged-cell SOFC stack design does not offer the large SOFC efficiency gain (over the standard cocurrent axial flow stack design) that was projected originally. Cell cooling in the fuel-entry cell rows reduces the average cell voltage while there is little increase in average fuel utilization at the last cell row at meaningful current densities because of the hazard of anode oxidation. 


\section{Recommendations:}

- Development of the PSOFC/ATS-GT power system concept should continue to refine the conceptual design and performance estimates, establish the method of operating (startup, power operation, shutdown) the PSOFC/ATS-GT power system, identify and resolve SOFC and Mercury ${ }^{\top M} 50$ integration issues, and develop a plan to demonstrate the power system concept.

- The PCS efficiency has a significant effect on the overall power system efficiency. For example, a gain in PCS efficiency of one percent translates to a system efficiency gain that approaches $6 / 10$ of one percentage point. Additional conceptual work should be done to determine if PCS efficiency gains above the $95 \%$ value developed and applied in this study could be achieved cost-effectively.

- SOFC development should be pursued to improve fuel cell power density and efficiency. As with the SOFC PCS, improvements in cell efficiency would be effective in increasing the efficiency of SOFC/GT power systems. 


\section{INTRODUCTION}

A simplified cycle diagram for a simple-cycle, atmospheric-pressure SOFC power system is provided in Figure 2-1. Fuel cell process air is supplied by the air blower, and the air is preheated as needed for SOFC thermal management using heat recovered at the recuperator from the SOFC exhaust gas. The SOFC generator operating pressure is near atmospheric, typically being in the 30 to $50 \mathrm{mbarg}$ range. SOFC power systems based upon this cycle are capable of design-point electric generating efficiencies in the $45 \%$ to $50 \%$ (net AC/LHV) range. The $100 \mathrm{kWe}$ SOFC combined heat and power (CHP) demonstration power system operating in the Netherlands is based on this cycle. This system, designed and fabricated by Siemens Westinghouse and EDB/ELSAM, a team of Dutch and Danish generating and distribution companies, and sponsored by EDB/ELSAM, is installed at a utility site near Arnhem. To date, the unit has logged over 15,000 operating hours, it is generating approximately $110 \mathrm{kWe}$ net $A C$ power at $46 \%$ efficiency (net AC/LHV) for the utility grid, and it also produces hot water for the local district heating system. The demonstrated system energy efficiency is nearly $75 \%$.

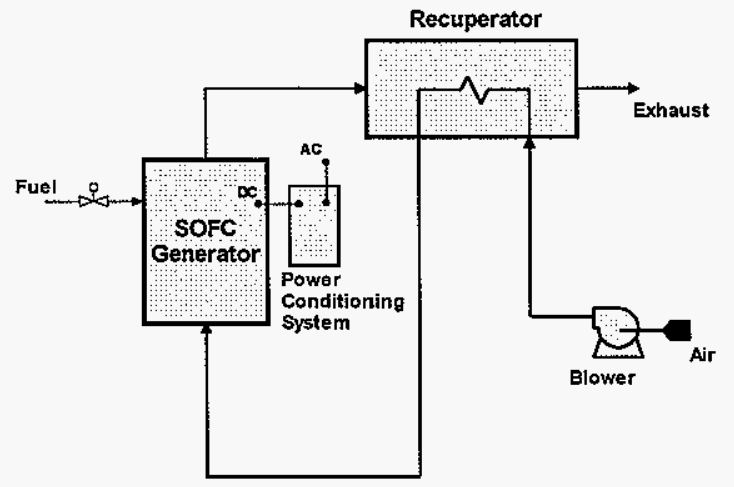

Figure 2-1 - Simplied atmospheric pressure SOFC power system cycle.

Power system efficiency can be increased by integrating the SOFC generator with a gas turbine in the cycle depicted in Figure 2-2. The SOFC generator in this cycle is pressurized (PSOFC), operating on air coming directly from the compressor discharge, via the turbine exhaust recuperator. The system based upon this cycle achieves high efficiencies due to the utilization by the gas turbine generator of thermal energy in the pressurized SOFC exhaust stream, which is accompanied by a corresponding reduction in the rate at which fuel is required by the gas turbine combustor. The SOFC generator will 
typically operate with an air inlet temperature of $550^{\circ} \mathrm{C}\left(1100^{\circ} \mathrm{F}\right)^{*}$ and an exhaust temperature of $870^{\circ} \mathrm{C}\left(1600^{\circ} \mathrm{F}\right)$, while the ATS gas turbine fires at $1160^{\circ} \mathrm{C}\left(2125^{\circ} \mathrm{F}\right)$. Thus, with this engine implemented, fuel firing at the combustor will be reduced by approximately $50 \%[(870-550) /(1160-550) * 100]$. It is noted that power system performance is also enhanced by SOFC generator operation at elevated pressure. For a given cell operating current, cell voltage, and hence cell power output and efficiency, increase with pressure.

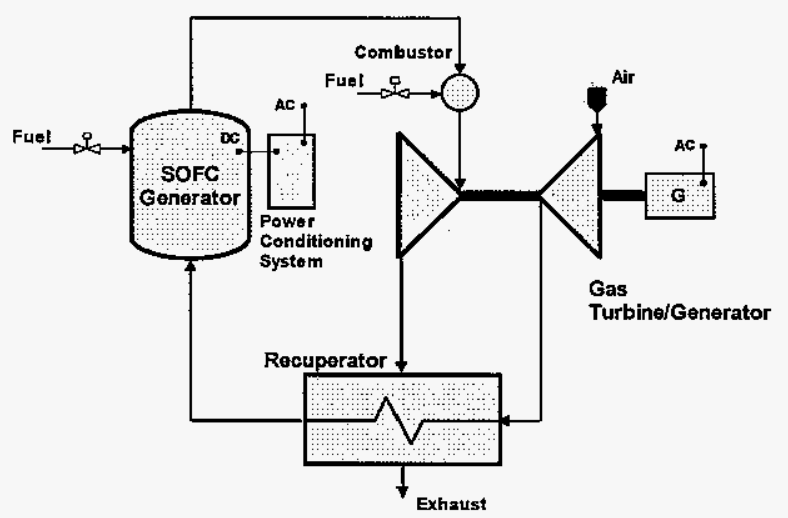

Figure 2-2 - Simplified PSOFC/GT hybrid power system cycle.

The purpose of the present project, undertaken by Siemens Westinghouse Power Corporation, in conjunction with Caterpillar, Inc, was to develop a conceptual design for a power system that applies the PSOFC/GT cycle and utilizes Solar Turbines ATS technology to achieve a low cost of electricity relative to the COE for systems based on current conventional power generation technologies. A secondary objective was to achieve a system with high power generation efficiency. The power system capacity was to be approximately $20 \mathrm{MWe}$. The gas turbine basis for the study was the Solar Turbines Mercury ${ }^{\mathrm{TM}} 50$ engine. The Mercury ${ }^{\mathrm{TM}} 50$ is a recuperated, single-shaft gas turbine that was developed by Solar Turbines under the U.S. Department of Energy ATS program. Operating on natural gas fuel, the engine generates $4.5 \mathrm{MWe}$ with an efficiency of approximately $41 \%$ (net AC/LHV). The turbine compressor intakes air at $16.6 \mathrm{~kg} / \mathrm{s} / 36.5$ $\mathrm{Ib} / \mathrm{s}$,$) and operates with a pressure ratio of 9.3: 1$ and turbine combustor temperature of $1160^{\circ} \mathrm{C}\left(2125^{\circ} \mathrm{F}\right\rangle$.

\footnotetext{
* Air temperature as delivered by the recuperator. Additional air heating occurs within the generator before cell entry.
} 


\section{RESULTS AND DISCUSSION}

\subsection{Power Plant Conceptual Design}

\subsubsection{Design Requirements and Objectives}

\subsubsection{Introduction}

This section establishes requirements and specifications that were used in developing the conceptual design for a low cost, high-efficiency fossil-fueled power plant. The plant concept was to be based on a hybrid concept that integrates Siemens Westinghouse SOFC and Solar Turbines Mercury ${ }^{\mathrm{TM}} 50$ ATS gas turbine technologies.

\subsubsection{Design Basis}

Power Plant Application

Commercial distributed-power generation

Output Power Specification

$60 \mathrm{~Hz} \mathrm{AC}$, at utility-grid voltage

Utility AC Grid Connection

Dispatch Mode

The power plant will be connected to the utility grid, and all net plant power will be exported to the grid.

Power Plant Heat Recovery

\section{Base load}

Heat will be recovered for plant power generation support; no heat will recovered for site thermal application.

Power Plant Startup

Installation

The utility $A C$ grid will be available for plant startup operations.

Outdoors.

Conceptual Design Scope

Power plant equipment between the site fuel supply point and the $A C$ grid interface will be included in the design. The equipment considered will be essential for plant startup, operation, control, shutdown, and maintenance. 
3.1.1.3 Performance Requirements

Power Plant Design-Point Capacity

Design-Point Efficiency

Power Plant Normal-Operation

Turndown Requirement

Power Plant Overpower Requirement

Output Power Conditions

Acoustic Noise Control
$20 \mathrm{MW}$ net $\mathrm{AC},+/-2 \mathrm{MW}$

High [approximately $60 \%$ (net AC/LHV)], consistent with achieving a minimum COE.

None

None

$60 \mathrm{~Hz}$

Utility-grid quality

Consistent with typical gas turbine practice.

3.1.1.4 Fuel and Oxidant Specifications at the Power Plant Design Point

Power Plant Fuel

Fuel composition

Methane

Nitrogen

Carbon dioxide

Sulfur bearing compounds Sulfur concentration

Fuel supply pressure

Fuel supply temperature

Oxidant

Air composition

Oxygen

Nitrogen

Carbon dioxide

Water

Ambient air temperature

Ambient air pressure
Natural gas

(mol percentages)

96

2

2

Mercaptans

$4 \mathrm{ppmv}$

1.034 barg (15 psig)

$15 \mathrm{C}(59 \mathrm{~F})$

Air (ISO conditions)

(mol percentages)

20.7

78.0

0.3

$1.0(60 \%$ relative humidity)

$15 \mathrm{C}(59 \mathrm{~F})$

1.014 barg (14.7 psia)

3.1.1.5 Ambient Air Ranges

Pressure

Temperature

Relative Humidity
Sea level to $1500 \mathrm{~m}(5000 \mathrm{ft}\rangle$

$-29 \mathrm{C}$ to $49 \mathrm{C}(-20 \mathrm{~F}$ to $120 \mathrm{~F})$

o to $100 \%$ 


\subsubsection{Power Plant Physical Design Objectives}

Major Subsystem Fabrication

Transportation Options

Site Installation Operations

Plant Design Lifetime

\subsubsection{Power Plant Operation}

Normal Power Operation Mode

Power Plant Startup

Annual Operating Time

Annual Planned Shutdown
Maximum practicable skid mounting at the factory.

Truck, sea, air, rail

Minimum component/skid assembly at installation site.

Interconnect factory-assembled skids at the site.

Interface the power plant with the site.

Conventional power plant equipment - 25 years.

Automatic, unattended, remotely monitored

Attended

Fifty weeks

Two weeks

\subsubsection{System/Site Interface Requirements}

Appropriate interface points will be available at the installation site for:

- Fuel supply

- Obtaining utility AC power during plant startup operations.

- Connecting the plant power output with the utility grid.

\subsubsection{Economic Evaluation Parameters}

Power System Cost Estimation Basis

Cost Basis
Costs will be based on the projected needs of mature SOFC/gas turbine technologies and commercial power plant operation, not first-of-a-kind.

Mid-1998 US dollars 
3.1.1.10 Economic Evaluation Parameters (continued)

$\begin{array}{ll}\text { Fuel Cost } & \$ 3.00 / \mathrm{MMBtu}(\mathrm{HHV}\rangle \\ \text { Capital Charge Rate } & 15 \% \\ \text { Availability } & 92 \% \\ \text { COE Evaluation Method } & \text { Constant dollars } \\ \text { Power Plant Optimization Basis } & \begin{array}{l}\text { Minimum COE. The target design-point } \\ \text { COE is } 10 \text { to } 20 \% \text { below the COE of to- } \\ \text { day's conventional plants. }\end{array} \\ \text { Transportation Cost Basis } & 800 \text { km }(500 \text { miles }) \text { - factory to installation } \\ & \text { site. } \\ \text { Conventional Power Plant COE Basis } & \text { Gas turbine combined cycle }\end{array}$

\subsubsection{Cycle and Power System Description}

A simplified power system cycle diagram for the PSOFC/ATS-GT power system is presented in Figure 3-1. As indicated above, the direct integration of a pressurized SOFC generator and a gas turbine results in the generation of electric power at high efficiency due to the extended processing to power by the gas turbine of an additional fraction of the system fuel energy that is not converted to power by the fuel cell, to the attendant reduction in the flow of fuel to the gas turbine combustor, and to the operation of the fuel cell generator at elevated pressure. Due to its high Brayton cycle efficiency lapproximately $41 \%$ ), which is achieved via the high turbine operating temperature and recuperation, the Mercury ${ }^{\mathrm{TM}} 50$ provides an excellent basis for the hybrid power system. 


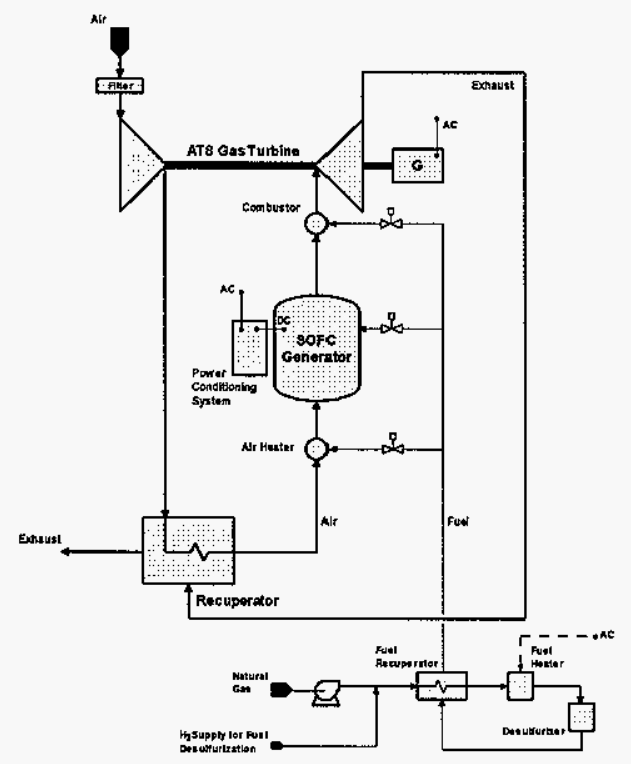

Figure 3-1 — Simplified PSOFC/ATS-GT hybrid power system cycle.

The system fuel is pipeline natural gas, assumed in this study to consist of $96 \mathrm{vol} \%$ methane, $2 \%$ nitrogen, and $2 \%$ carbon dioxide. The gas also contains sulfur-bearing compounds, occurring naturally, or added to enable leak detection. The sulfur concentration in the raw fuel, per the design requirements, is $4 \mathrm{ppmV}$, and it must be reduced to the $0.1 \mathrm{ppmV}$ level prior to SOFC generator entry to preclude sulfur reaction (reversible) with SOFC nickel components. After the fuel has been hydrogenated, the desulfurizer in this power system concept processes the sulfur to hydrogen sulfide in a cobaltmolybdenum catalyst bed, and the $\mathrm{H}_{2} \mathrm{~S}$ is adsorbed on a bed of hot zinc oxide, which operates optimally at $350^{\circ} \mathrm{C}$ to $400^{\circ} \mathrm{C}\left(660^{\circ} \mathrm{F}\right.$ to $\left.750^{\circ} \mathrm{F}\right)$. This temperature level is achieved recuperatively and by electric heat addition. The power required for fuel heating is small, and the system is simple and requires low maintenance. Alternatively, the heat for this process could be derived from the turbine exhaust, at the expense of complicating the turbine exhaust design. Hydrogen for the fuel desulfurization process is generated on site. 
The SOFC generator produces DC power, which is prepared for export to the utility AC grid by the power conditioning system. AC power is also produced for export by the gas turbine.

The Mercury ${ }^{\mathrm{TM}} 50$ compressor is composed of ten axial stages. Power to drive the compressor, and the $\mathrm{AC}$ generator, is derived from a two-stage axial turbine. The compressor air intake rate is $16.6 \mathrm{~kg} / \mathrm{s}(36.5 \mathrm{lb} / \mathrm{s})$, and the design compressor pressure ratio is 9.3:1. As Figure 3-1 indicates, the rotating gas turbine components are installed on a single shaft. This issue was not investigated in detail during this project, but it is anticipated that in the developed power system, the electric load on the gas turbine generator will be modulation-capable to permit the maintenance of set point shaft speed. This feature will assure a steady flow of air to the SOFC generator, an important function of the gas turbine, and a necessity to provide for SOFC thermal management.

A pictorial view of the power system is presented in Figure 3-2. The power system is arranged in two power system blocks. Each block employs a single Mercury ${ }^{\mathrm{TM}} 50$ gas turbine that is integrated with an SOFC generator, and each generator consists of several SOFC modules that are arranged in flow parallel between process air and exhaust manifolds. The number of SOFC generator modules (four) to be associated with each gas turbine has been determined to yield a minimum COE value. Each module is a horizontal cylindrical pressure vessel, flanged at the middle, that houses a cell stack assembly. The basic stack building block is the 576-cell substack pictured in Figure 3-3. The individual cells are tubular, with active lengths of $1500 \mathrm{~mm}$ and diameters of $22 \mathrm{~mm}$. They are arranged in the substack in the vertical orientation, with closed ends at the bottom. Shown at the top of the substack are air distribution plena through which process air is admitted to the cell air injection tube inlets, and on the side of the substack, shown are the depleted-fuel recirculation plenum, the ejector that drives the depleted-fuel recirculation, the fuel prereformer, and the ducting for distributing the fresh-fuel/recirculatedfuel mixture to the underside of the substack. Within the substack, methane reformation occurs in the in-stack reformers located between the cell bundles, and the reformed fuel mixture is then distributed to the individual cells. At the cells, the fuel mixture and air flow cocurrently from the cell closed ends, and a fraction of the $\mathrm{CO}$ and $\mathrm{H}_{2}$, typically $85 \%$ to $90 \%$, is processed electrochemically. Twenty 576 -cell substacks compose the cell stack assembly in a single generator module. 
Note the two power blocks are independent. Provided the balance-of-plant equipment is available, one block could be operated while the other block is down for maintenance.

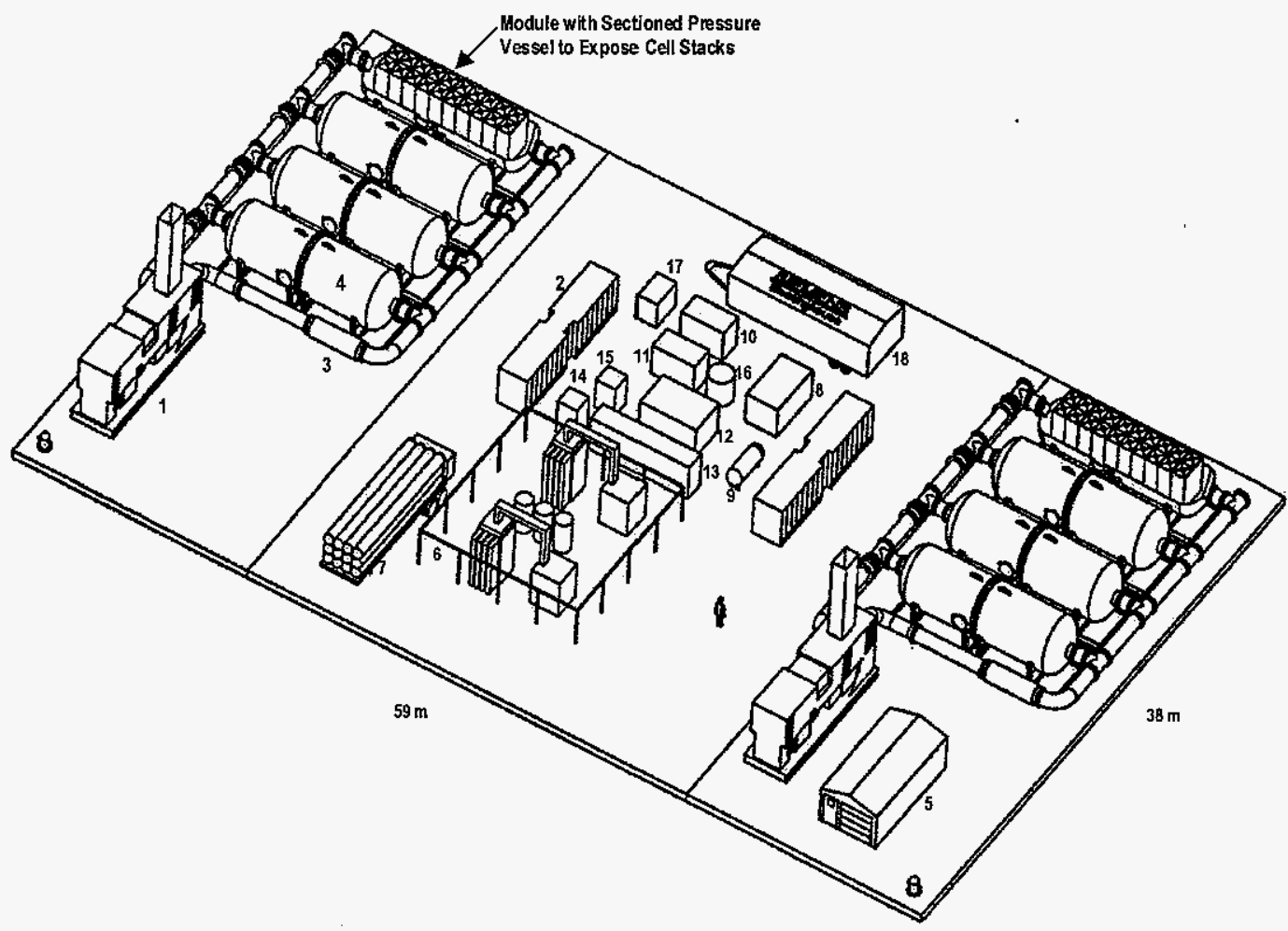

Key: $\quad$ 1. Mercury ${ }^{\mathrm{TM}} 50$ Gas Turbine

2. Power Conditioning System

3. Air Heater

4. PSOFC Generator Module

5. Storage

6. 20 MW Substation

7. $\mathrm{N}_{2}$ Tube Trailer

8. $\mathrm{N}_{2}$ Generator/Compressor

9. Propane Tank

10. Auxiliary Air Compressor

11. Natural Gas Compressor

12. Desulfurizer

13. Electrical Cabinets

14. UPS Shed

15. $\mathrm{H}_{2}$ Generator/Compressor and Gas Mixer

16. Water Storage Tank

17. Startup Boiler

18. Control Room

Figure 3-2 - 20 MWe PSOFC/ATS-GT power system site arrangement. 


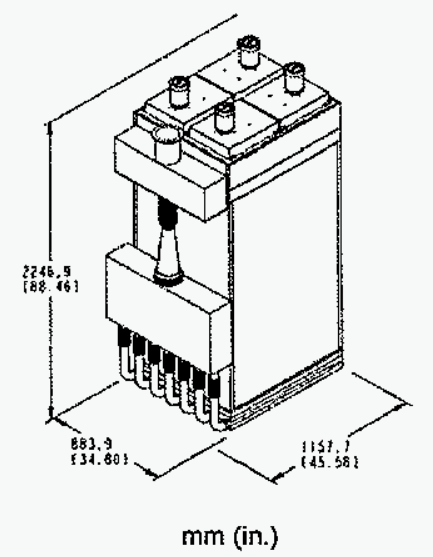

Figure 3-3-576-cell substack.

\subsubsection{Power System Performance Analysis}

\subsubsection{Analysis Basis}

Basic input for the analysis such as fuel composition, fuel supply conditions, and ambient-air conditions were taken from the design requirements, Section 3.1. Additional information on key input is provided in the following:

- Cell V-I characteristic - the V-l characteristic is graphed in Figure 3-4. It is a projected characteristic for the mature SOFC product that will be available in 2005 to 2010. The V-I characteristic applies to operation at 1 atm (abs), $85 \%$ fuel utilization, and to a peak cell temperature of $1020^{\circ} \mathrm{C}\left(1870^{\circ} \mathrm{F}\right)$.

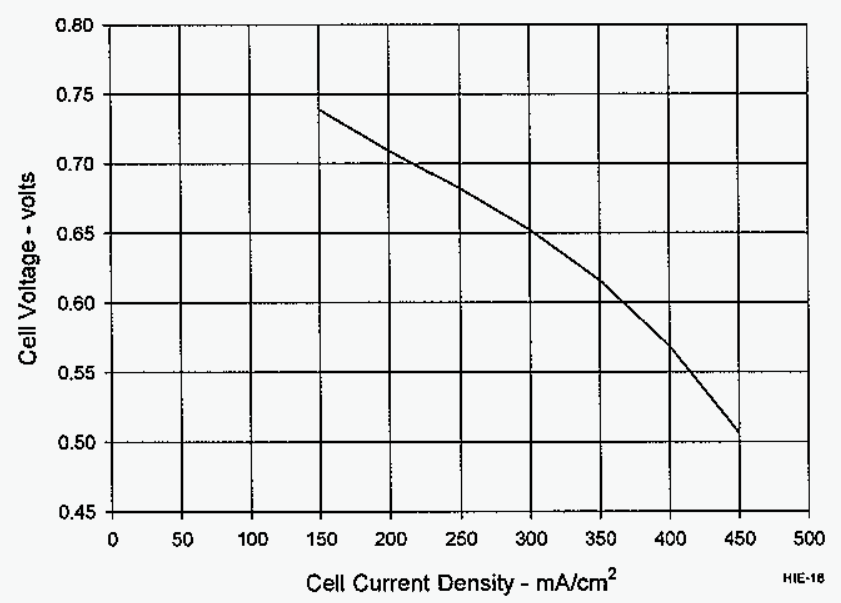

Figure 3-4 - Cell V-I characteristic. 
- Cell voltage correction for SOFC generator operation at elevated pressure - A cell voltage adjustment for operation at pressures above $1 \mathrm{~atm}$ (abs) is presented in Figure $3-5$. Given an operating pressure, the corresponding voltage adjustment is added to the base cell voltage from Figure 3-4. Data for Figure 3-5 were obtained from cell testing (Test No. 503) performed at Ontario Hydro Technologies $(\mathrm{OHT}$ ) in Toronto, Ontario, Canada by OHT personnel. The test article was designed and supplied by Siemens Westinghouse. The tests covered the pressure range from $1 \mathrm{~atm}$ (abs) to $15 \mathrm{~atm}$ (abs). Over the cell current density range of interest in this conceptual design study, the adjustment for pressure is essentially independent of current density.

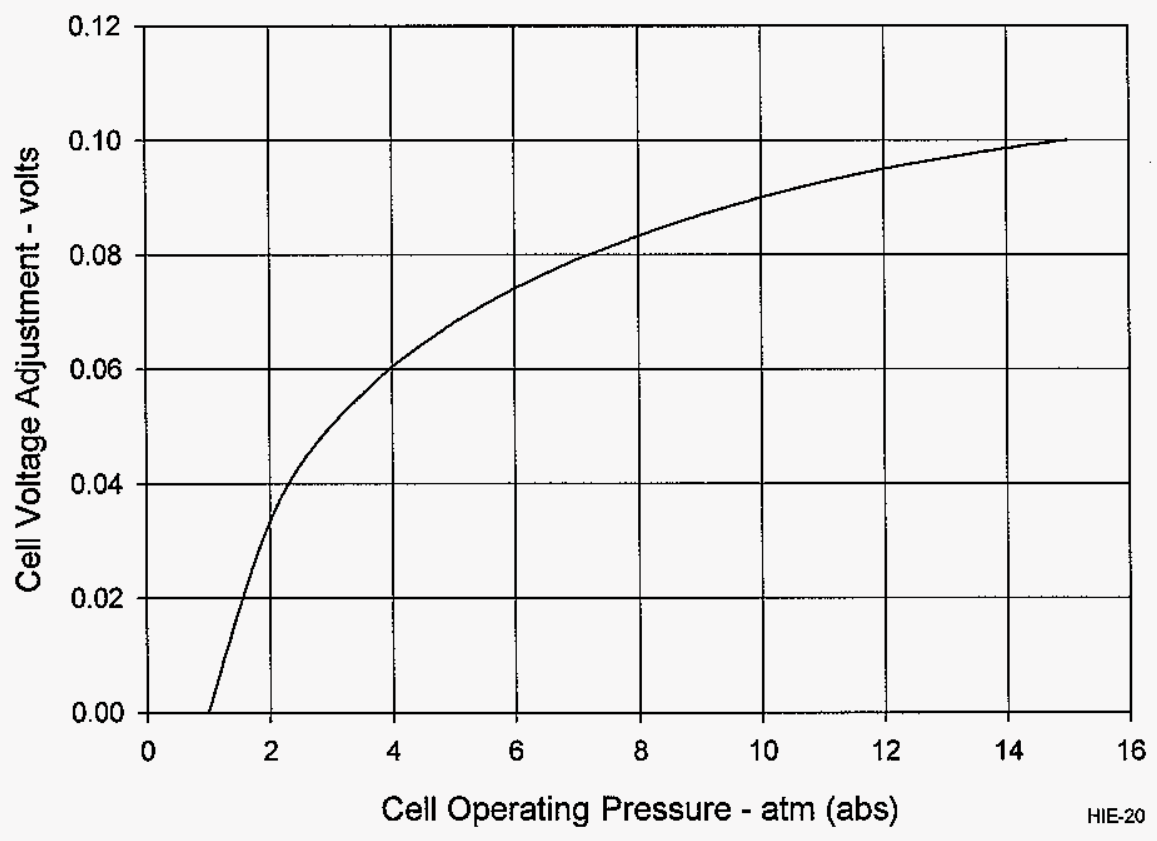

Figure 3-5 - Cell voltage adjustment for pressure.

- Stoichs profile - air flow to the SOFC generator is determined by the stoichs profile that is graphed in Figure 3-6. Its application results in cell operation with a peak cell temperature of $1020^{\circ} \mathrm{C}\left(1870^{\circ} \mathrm{F}\right)$ and a generator combustion zone exhaust temperature of approximately $870^{\circ} \mathrm{C}\left(1600^{\circ} \mathrm{F}\right)$. One stoich provides the normal-air flow needed to supply oxygen for the cell electrochemical process. A generator air flow based upon multiple stoichs provides the required amount of oxygen for that process, and it flattens the cell axial temperature distribution, thereby raising the cell average temperature and operating voltage. 


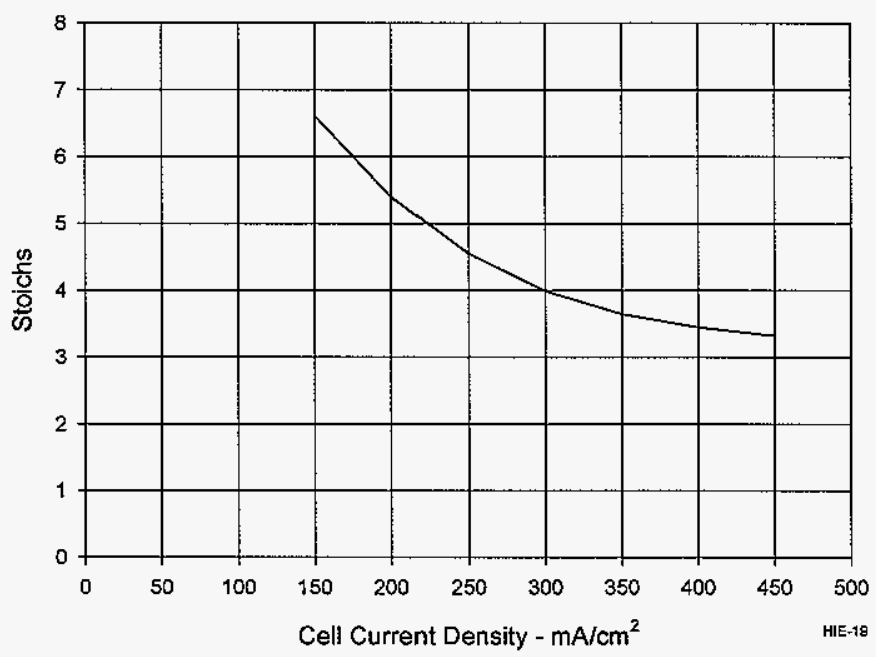

Figure 3-6 - Stoichs profile.

- Electrochemical fuel utilization - generator fuel consumption was set at $85 \%$, meaning $85 \%$ of the fuel admitted to the SOFC generator was consumed electrochemically on the cell active surface and by the ionic and molecular leakage of oxygen from the cathode side of the cell to the anode. Approximately $84 \%$ of the generator fuel is consumed electrochemically.

- SOFC power conditioning system efficiency - 95\% (DC-to-grid AC), based on project PCS conceptual design.

- Gas turbine generator efficiency $-96 \%$.

- Gas turbine compressor isentropic efficiency $-87.5 \%$.

- Turbine isentropic efficiency $-87.6 \%$.

- Turbine mechanical efficiency $-97 \%$.

- Turbine gear box efficiency $-98 \%$.

- Auxiliary power losses - $20 \mathrm{kWe}$ [l\&C, cabinet ventilation] for one $10 \mathrm{MWe}$-class power block.

\subsubsection{Power System Performance Estimates}

Power system design-point performance estimates are summarized in Table 3.1. They apply to a single PSOFC/ATS-GT power block, consisting of one Mercury ${ }^{\mathrm{TM}} 50$ gas turbine and an SOFC generator composed of four generator modules. Two such power blocks would be arranged and operated in parallel in a $20 \mathrm{MWe}$-class power system. Performance estimates for this total system are presented in Table 3.2. 
Table 3.1 - Power Block Design-Point Performance Estimates

\begin{tabular}{|l|c|}
\hline Compressor air intake rate & $16.6 \mathrm{~kg} / \mathrm{s}(36.6 \mathrm{lb} / \mathrm{s})$ \\
\hline Compressor pressure ratio & $9.5: 1$ \\
\hline Gas turbine combustor temperature & $1160 \mathrm{C}(2125 \mathrm{~F})$ \\
\hline SOFC gross AC power & $7.9 \mathrm{MWe}$ \\
\hline Gas turbine gross AC power & $4.8 \mathrm{MWe}$ \\
\hline Power block net AC power & $12.3 \mathrm{MWe}$ \\
\hline Fuel flow rate to SOFC generator & $0.31 \mathrm{~kg} / \mathrm{s}(0.68 \mathrm{lb} / \mathrm{s})$ \\
\hline Fuel flow rate to gas turbine combustor & $0.14 \mathrm{~kg} / \mathrm{s}(0.31 \mathrm{lb} / \mathrm{s})$ \\
\hline Efficiency (net AC/LHV) & $59.9 \%$ \\
\hline Carbon dioxide emission & $340 \mathrm{~kg} / \mathrm{MWh}(750 \mathrm{lb} / \mathrm{MWh})$ \\
\hline $\begin{array}{l}\text { Nitrogen oxide emission (based on } 5 \mathrm{ppmv} \text { addi- } \\
\text { tion at the gas turbine combustor. }\end{array}$ & $0.04 \mathrm{~kg} / \mathrm{MWh}(0.09 \mathrm{lb} / \mathrm{MWh})$ \\
\hline Sulfur oxide emission & 0 \\
\hline Exhaust flow rate & $16.9 \mathrm{~kg} / \mathrm{s}(37.2 \mathrm{lb} / \mathrm{s})$ \\
\hline
\end{tabular}

\section{Table 3.2 - Power System Design-Point Performance Estimates} (Power System Definition: Two Power Blocks)

\begin{tabular}{|l|c|}
\hline Air intake rate & $33.2 \mathrm{~kg} / \mathrm{s}(73.2 \mathrm{lb} / \mathrm{s})$ \\
\hline Fuel flow rate & $0.90 \mathrm{~kg} / \mathrm{s}(2.0 \mathrm{lb} / \mathrm{s})$ \\
\hline Net AC power & $24.7 \mathrm{MWe}$ \\
\hline Efficiency (net AC/LHV) & $59.9 \%$ \\
\hline Exhaust flow rate & $33.9 \mathrm{~kg} / \mathrm{s}(75.0 \mathrm{lb} / \mathrm{s})$ \\
\hline
\end{tabular}

Corresponding to the operating point represented in Table 3.1, and for the points identified in Figure 3-7, estimates of cycle statepoint parameters are provided in Table 3.3. 


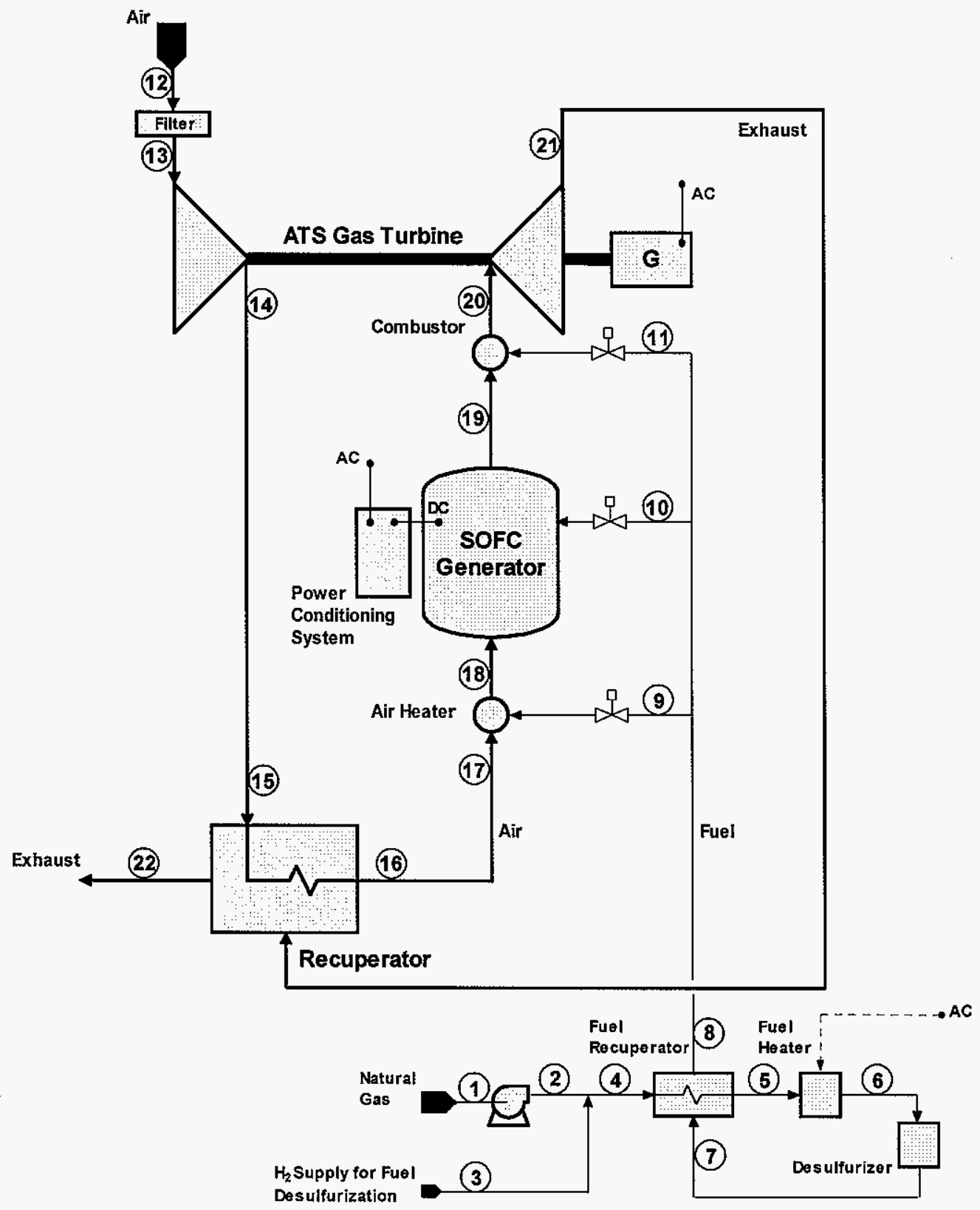

Figure 3-7 - Power block statepoint diagram. 
Table 3.3 - Power Block Statepoint Parameter Estimates

\begin{tabular}{|c|c|c|c|c|c|}
\hline $\begin{array}{c}\text { Statepoint } \\
\text { ID }\end{array}$ & $\begin{array}{c}\text { Mass Flow, } \\
\mathbf{k g} / \mathbf{h}\end{array}$ & $\begin{array}{c}\text { Temperature, } \\
\mathbf{C}\end{array}$ & $\begin{array}{c}\text { Pressure, } \\
\text { bara }\end{array}$ & $\begin{array}{c}\text { Molecular } \\
\text { Weight }\end{array}$ & $\begin{array}{c}\text { Enthalpy } \\
\text { Flux, } \mathbf{M W}\end{array}$ \\
\hline 1 & 1,620 & 15 & 2.05 & 16.8 & -0.010 \\
\hline 2 & 1,620 & 212 & 12.65 & 16.8 & 0.214 \\
\hline 3 & 2 & 15 & 12.65 & 2.0 & \\
\hline 4 & 1,622 & 212 & & 16.7 & 0.214 \\
\hline 5 & 1,622 & 375 & & 16.7 & 0.439 \\
\hline 6 & 1,622 & 399 & & 16.7 & 0.476 \\
\hline 7 & 1,622 & 399 & & 16.7 & 0.476 \\
\hline 8 & 1,622 & 237 & & 16.7 & 0.246 \\
\hline 9 & 0 & & & & 0 \\
\hline 10 & 1,114 & 93 & & 16.7 & 0.050 \\
\hline 11 & 508 & 93 & & 16.7 & 0.023 \\
\hline 12 & 59,656 & 15 & 1.01 & 28.6 & -0.166 \\
\hline 13 & 59,656 & 15 & 1.01 & 28.6 & -0.166 \\
\hline 14 & 59,656 & 304 & 9.61 & 28.6 & 4.795 \\
\hline 15 & 57,687 & 304 & & 28.6 & 4.637 \\
\hline 16 & 57,687 & 631 & 9.26 & 28.6 & 10.395 \\
\hline 17 & 57,687 & 629 & & 28.6 & 10.360 \\
\hline 18 & 57,687 & 629 & & 28.6 & 10.360 \\
\hline 19 & 58,801 & 877 & & 28.4 & 15.851 \\
\hline 20 & 60,950 & 1160 & 8.89 & 28.2 & 22.467 \\
\hline 21 & 60,950 & 656 & 1.06 & 28.2 & 12.090 \\
\hline 22 & 60,950 & 360 & 1.01 & 28.2 & 6.215 \\
\hline
\end{tabular}

\subsubsection{Elevated SOFC Generator Operating Pressure}

As indicated earlier, the SOFC generator design utilizes the conventional generator configuration, and in addition, the design assumes the uniform distribution of air flow between cells, and the uniform distribution of reformed-fuel flow on the cell anode side. In the conventional generator configuration, fuel flows upwards along the cell exterior surfaces (anodes) in the system of communicating parallel flow channels that is defined by the anodes. That this configuration is suitable for atmospheric-pressure generators has been confirmed via current and past field unit demonstrations, and a pressurized bundle at three atmospheres pressure has also exhibited good, stable performance. However, it is not known with certainty that this parallel flow channel configuration is suitable for higher pressure SOFC generators. Flow channel pressure drop is determined by friction and buoyancy components. At low pressures, the friction component, varying inversely with gas density, and hence with pressure, is dominant, and the buoyancy effects of 
modest channel-to-channel temperature or composition variations are of little consequence. However, at elevated operating pressures, the buoyancy effect, being proportional to density differences, has more influence, while the friction pressure drop component, with its inverse pressure relationship, is diminished. At higher pressure $(P>3$ atm) transverse channel-to-channel parameter variations could affect parallel-channel flow stability, and this is of special concern considering the density of the oxidation product stream that exits the channels at the top will be larger than the density of the reformed fuel stream that enters at the bottom. It is therefore clear that cell-stack thermal and hydraulic interactions need to be well understood, particularly relative to stack operation at elevated pressure levels. A very reasonable first step in developing this understanding would be to undertake a detailed analytical evaluation of the anode-side flow field and of the effect of operating pressure on that field.

\subsubsection{Power Plant and Site Arrangement}

Power system pictorial and plan views are presented in Figure 3-8 and Figure 3-9.

The arrangement includes a trailer mounted control/meeting room with sanitary facilities and four-space parking area, a storage shed, a $20 \mathrm{MW}$ substation/switchyard, two fire hydrants, intake air filter house and the BOP equipment block. The BOP equipment block is shown between the control trailer and switchyard. The BOP equipment block is comprised of several equipment, component and electrical skids. Each skid is mounted to a dedicated concrete pad or foundation. The various skids are in weatherproof enclosures:

- Natural gas desulfurizer

- Pressurized nitrogen storage cylinders

- Nitrogen generator and compressor

- Hydrogen generator, compressor and gas mixing equipment 


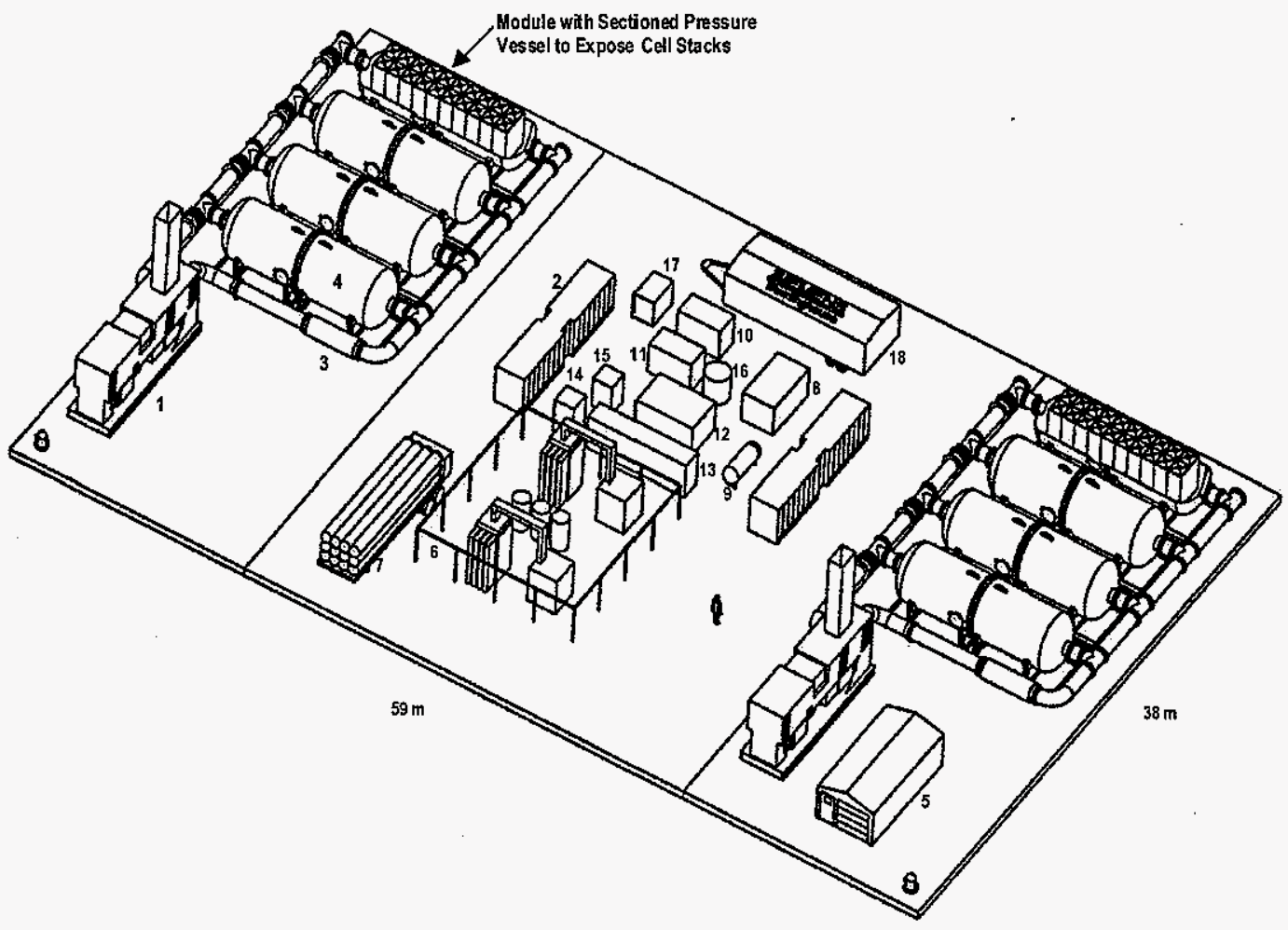

Key: 1. Mercury ${ }^{\mathrm{m}} 50$ Gas Turbine

2. Power Conditioning System

3. Air Heater

4. PSOFC Generator Module

5. Storage

6. 20 MW Substation

7. $\mathrm{N}_{2}$ Tube Trailer

8. $\mathrm{N}_{2}$ Generator/Compressor

9. Propane Tank
10. Auxiliary Air Compressor

11. Natural Gas Compressor

12. Desulfurizer

13. Electrical Cabinets

14. UPS Shed

15. $\mathrm{H}_{2}$ Generator/Compressor and Gas Mixer

16. Water Storage Tank

17. Startup Boiler

18. Control Room

Figure 3-8 -20 MW PSOFC/ATS-GT power system arrangement. 


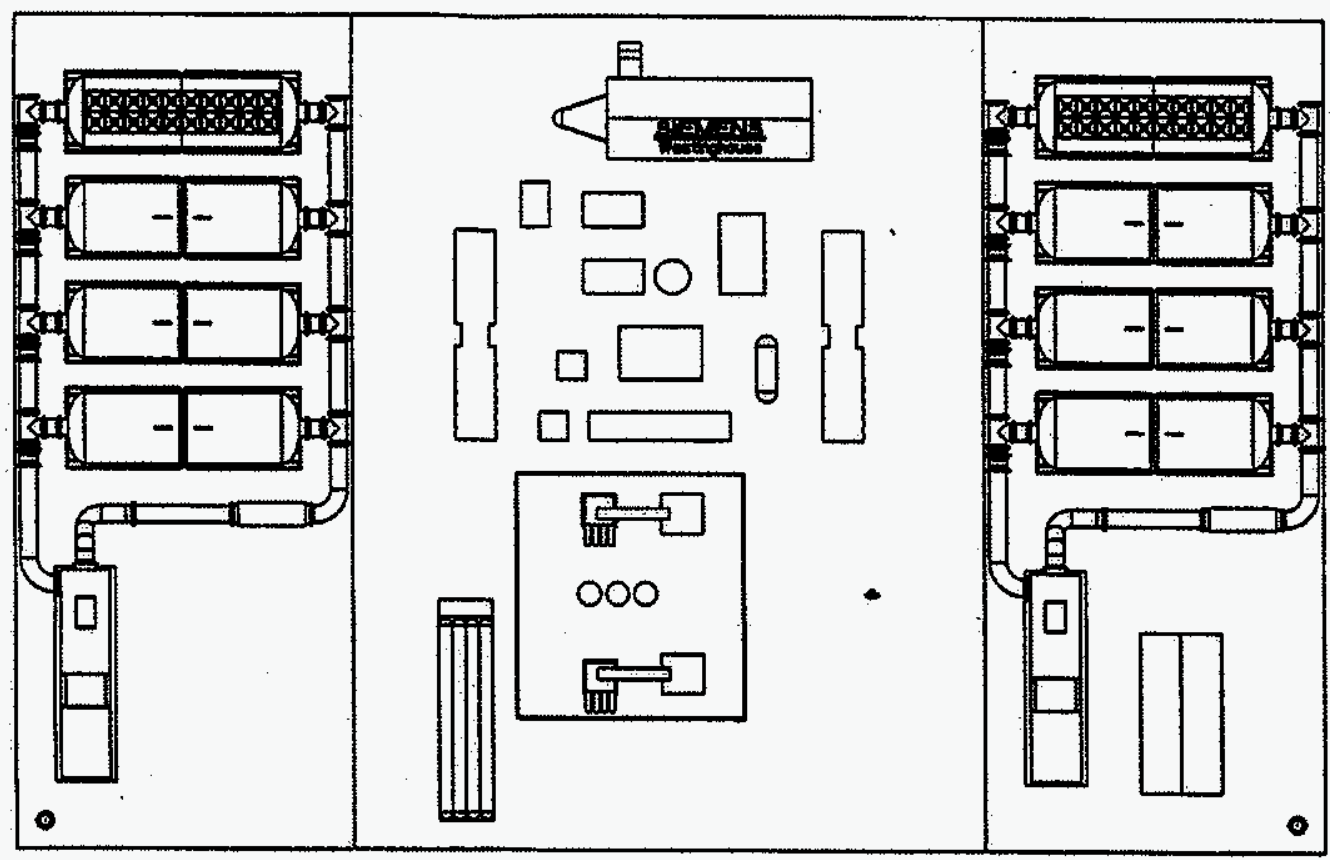

Figure 3-9 - 20 MWe PSOFC/ATS-GT power system site arrangement plan view. 
Not shown are the security fence and its gates around the perimeter or any storm water drainage features. These features will generally be site specific. Structural support steel, ladders, platforms, overhead high voltage power lines and their poles from the SOFC vessels and GT skid are also not shown.

For this study it is presumed that direct access to the site is via paved roadway capable of bearing the loads from the heaviest items [GT skid weight is $43,100 \mathrm{~kg}(95,000 \mathrm{lb})$, and the SOFC vessel half weight with internals is $25,400 \mathrm{~kg}(56,000 \mathrm{lb})]$. The site must also have direct connections to natural gas, city water, sanitary sewer, telephone and electric power.

To minimize field construction, each SOFC vessel half with SOFC stacks installed is factory fabricated on a transportable trailer/skid. This foundation trailer is field mated with the trailer bearing the other half of the SOFC vessel. After proper alignment of the vessel/trailer halves, the trailers are blocked and the wheels removed. In the event that a vessel half is to be returned to the factory for maintenance or repair, the wheels can be reinstalled on the foundation trailer, the blocks removed and the trailer towed away.

Access to the switchyard is available on two sides and the BOP equipment block also has fork truck clearance between skids. The process piping is factory-fabricated internally-insulated flanged sections. Where possible, external jacketed thermal insulation is applied at the factory to minimize field construction. These sections are relatively large and heavy, varying from about $1000 \mathrm{~kg}$ per meter (670 pounds per linear foot) to about $1500 \mathrm{~kg}$ per meter (1000 pounds per foot). They are assembled on site by landing them on their pipe supports and bolting together the gasketed, flanged joints. Thermal expansion joints are provided between significant runs of piping as needed. The plant arrangement drawings do not show the detail of the flanged joints in the process piping or the pipe supports.

The arrangement uses SOFC pressure vessels with process air entry and exhaust exit at opposite ends. The pneumatic balancing for equal distribution of air to the cells is straightforward. The significant consequence of the vessel with nozzles on both ends is the need to use a relatively large quantity of large diameter, internally and externally insulated piping. This plant occupies the smallest amount of ground of the arrangements studied (see Section 3.4.5). The plot plan measures $59 \mathrm{~m}$ (194ft) by $38 \mathrm{~m}$ (125 ft), 0.56 acres in area. 
The SOFC generator modules are accessible from each end, and there is space for a vehicle access road at each end. Access for inspection, repair or maintenance is good. Routing of high voltage electric power lines from the SOFC vessels to the switchyard is efficient. The DC power generated in each vessel is routed through thermally and electrically insulated feedthroughs to a nearby package containing a $D C$ to $A C$ inverter with step-up transformer. The inverter/transformer package is mounted in a weather proof cabinet at the site. The inverter/transformer package terminates with three standard high voltage insulators. The three phase $13.8 \mathrm{kV}$ high voltage lines rise from the inverter/transformer package and connect to their respective phase feeder lines. These feeder lines run overhead to the switchyard.

\subsection{Systems and Components}

A simplified process diagram that identifies systems and components is presented in Figure 3.10. In this process diagram one of two PSOFC/ATS-GT power blocks is shown, and within the power block, only one vessel of four is shown.

\subsubsection{SOFC Generator}

\subsubsection{Staged-Cell Generator Concept Evaluation}

Two separate analyses were made to evaluate the staged fuel cross-flow stack concept. The original analysis used the coupled thermal/electrochemical model and applied specifically to the tubular SOFC geometry. This analysis and its results are summarized below. The isothermal model was created to independently verify that the benefits of staging were much smaller than had been anticipated. The isothermal model is general and is not limited to a particular cell or stack geometry. The isothermal model is presented in Appendix A. The results of the two analyses are combined in the summary at the end of this section. The analytical models consider an SOFC bundle row consisting of four bundles, each bundle consists of a three-cell-in-parallel by eight-cells-in-series array. The bundle row is flanked by in-stack reformers. 


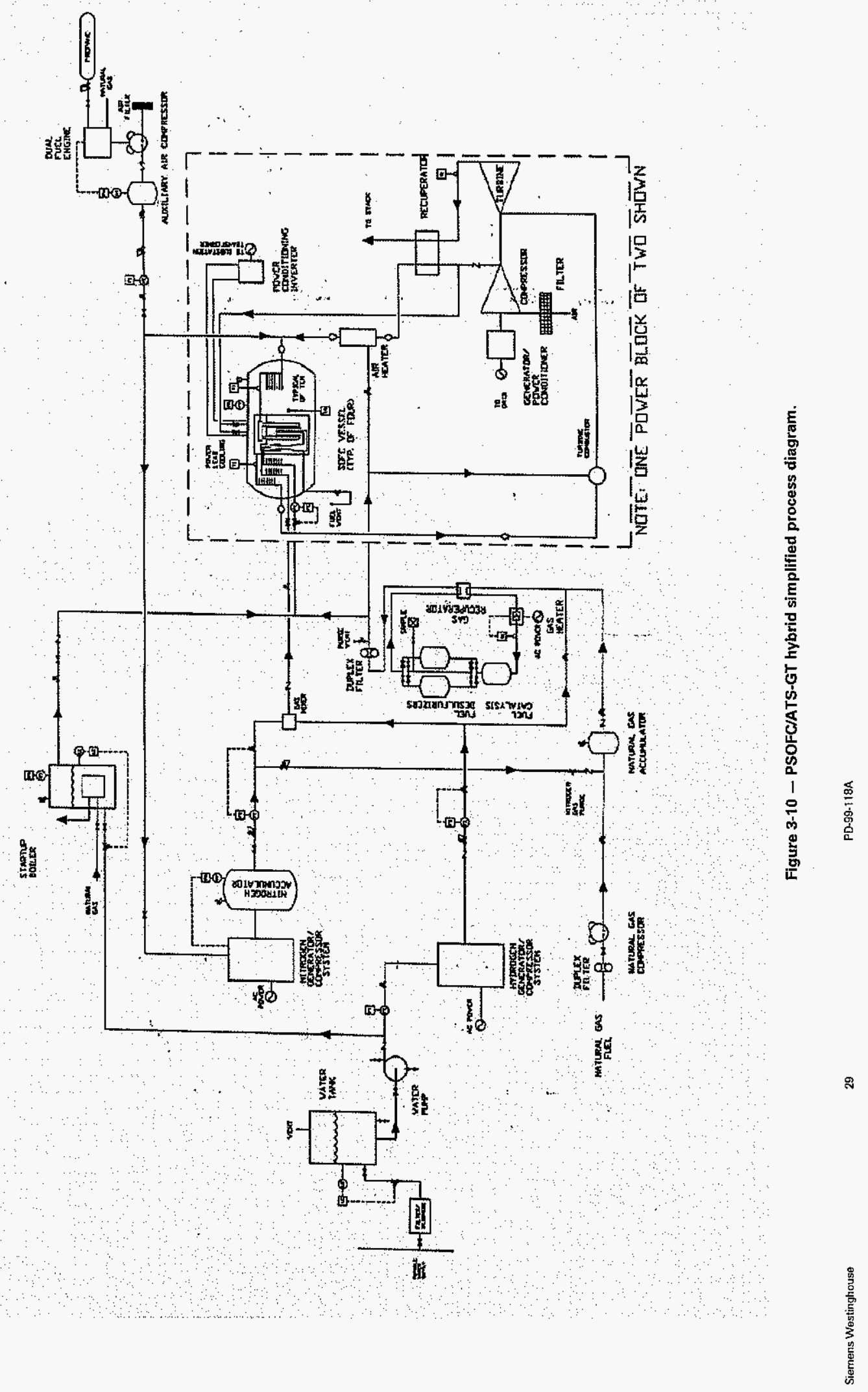




\subsection{Coupled Analysis of the Staged Fuel Cross-flow Stack}

This section gives an overview of the coupled cell/stack analysis model used to evaluate the staged fuel cross-flow stack. The model was based on cross-flow of fuel through four bundles in series. Thus, fuel passes sequentially across a total of 32 cells. The cross flow stack analysis model was developed for a stack that would replace a conventional stack that has axial fuel flow. The staged-cell stack has recirculated fuel and is coupled to the in-stack reformer board (SRB) assembly positioned between each pair of bundle rows. Thus the cell configuration of the stack remains essentially unchanged, with the exception that fuel flows in at one side, through the stack, and exits on the other side. From there the fuel passes back through the recirculation zone to the inlet side of the stack where it is mixed with fuel feed and pre-reformed. The exhaust portion of the spent fuel exits to the combustion zone as it passes through the recirculation zone. A side view of the fuel flow through the stack and SRBs is shown in Figure 3-11.

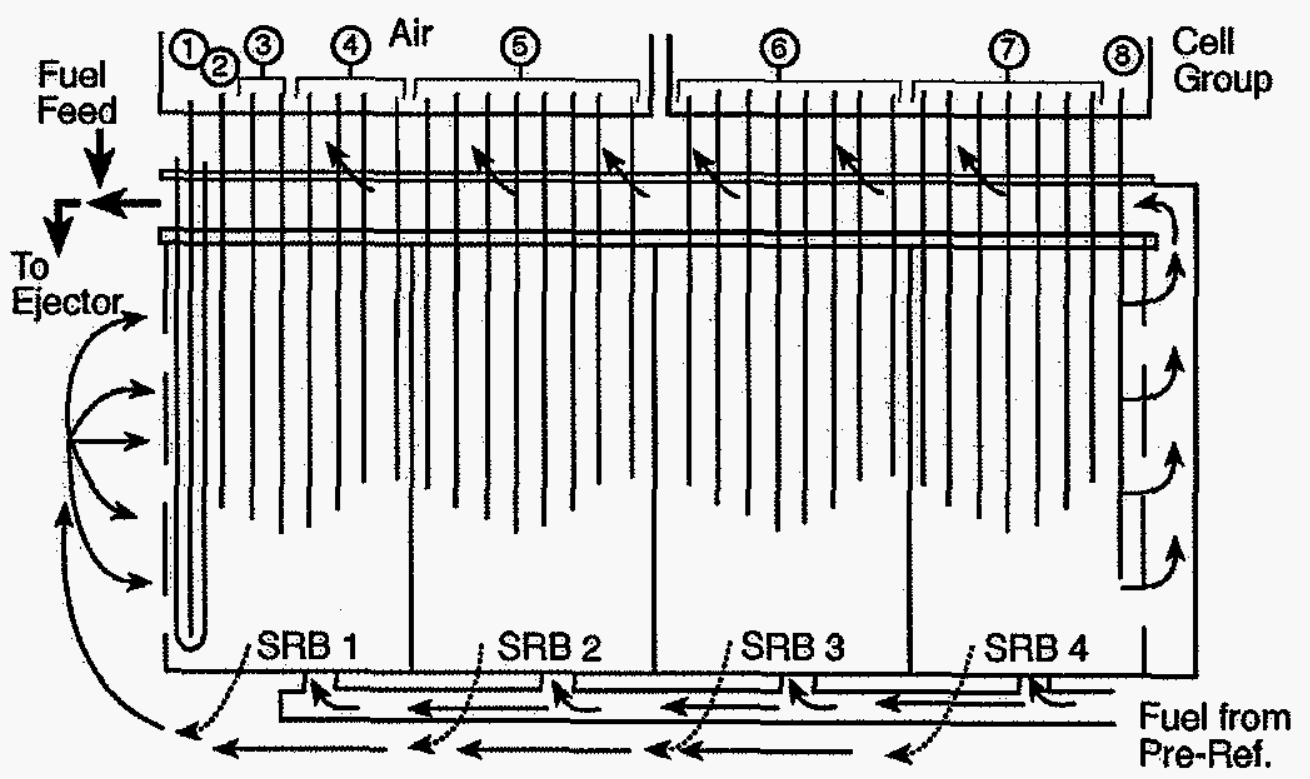

Figure 3-11 - Staged-cell generator concept. 
The model is a fully coupled heat transfer, mass transfer, and electrochemical analysis. Local temperatures are used to evaluate all local properties including thermal conductivity, mass diffusion coefficients, electrical resistivity, and gas transport properties. Local temperatures and concentrations are used to calculate the Nernst potential, cell resistance, polarization losses, and the local current density. Fuel and oxidant streams are depleted based on local current density. Local heat generation includes the excess heat of reaction, Joule and polarization losses, and heating due to $\mathrm{O}_{2}$ ionic leakage through the cell. Heat transfer coefficients are also based on properties evaluated at local temperatures. Radiation heat transfer is calculated based on the fourth power law. For all models that include an SRB, the temperature and the heat flux from the cell are matched with the temperature and the heat flux to the SRB. The reformation model of the SRB satisfies heat transfer, mass diffusion, reaction rate and chemical equilibrium conditions.

The development of the analysis model for the cross flow stack is based on a similar model that has been used for the conventional stack. To include a number of stages, the number of axial segments per stage between the closed end of the cell and the fuel recirculation zone was reduced to 20 . Further, it was decided to divide the 32 cell stages into groups of cells. The cells in each group would be represented by the conditions at the center cell of the group. The group arrangement selected is shown in Figure 3-11. To provide detail at the inlet fuel side of the stack, the first two groups include only one cell each. The third group includes 2 cells, the fourth group includes 4 cells, and the fifth and the sixth groups include 8 cells each. The seventh and eighth groups include seven cells and one cell, respectively. Note that the bundle and SRB boundaries coincide with group boundaries. This was required to simplify the coupling of the SRBs and the cells.

The initial results from the staged configuration were disappointing. The problems can be described as follows.

1. The first cell row (at the fuel inlet) was too cold and final cell rows were too hot. This is a consequence of the large flow of relatively cold fuel that impacts directly onto the first stage or the first cell row. The latter cell rows become hotter as the fuel temperature increases and cell losses increase as fuel is depleted.

2. The overall temperature uniformity was poor. This is a result of the combination of the superposition of the row-to-row temperature distribution on the axial temperature distribution. The overall non-uniformity is the sum of the two. 
3. The fuel concentration becomes non-uniform in the latter cell rows. The fuel is consumed at a higher rate at the hotter portions of the cell due to the lower local cell resistance. After passing a number of cell rows, the fuel becomes depleted in the central region of the cells. To preclude anode oxidation, the average fuel utilization at bundle row exit must be comparable to that for an axial-flow cell stack - a higher fuel utilization is not feasible.

4. The average cell voltage was lower than for an axial flow stack due to the lower overall average temperature.

Several modifications were made to the model stack to address the issues of temperature uniformity.

1. The inserts normally used to enhance heat transfer within the combustion zone region were removed from the air feed tubes in the last three cell bundles (24 cell rows). Removal of the inserts results in reduced pressure drop which acts to increase the cooling flow of air to the last 24 cell rows relative to the cooling flow to the first 8 cell rows. Removal of inserts also reduces the pre-heating of cooling air to the last 24 cell rows, thereby lowering their temperature relative to the inlet cell rows.

2. The fuel flow to the SRB adjacent to the first cell bundle was restricted by an orifice. This reduces the cooling of the first 8 cell rows at the inlet side of the stack. It also increases cooling of the last cell rows by shifting the reformation heat load toward the exit side of the stack.

\subsection{Results of Coupled Analysis of Staged-Cell Stack}

Results for the staged-cell stack with the modifications listed above are shown in Figure 3-12, Figure 3-13, and Figure 3-14. The cell current was $253 \mathrm{~A} /$ cell corresponding to a current density of $304 \mathrm{~mA} / \mathrm{cm}^{2}$. Air inlet temperature was selected to give a maximum local cell temperature of $1020^{\circ} \mathrm{C}(1870 \mathrm{~F})$. The temperature distributions of the cells at the center of each of the 8 cell groups are shown in Figure 3-12. Figure 3-13 displays the average cell temperature and the terminal voltage as a function of the cell row position. The fuel concentration profiles at the exit of the 8 cell groups are shown in Figure 3-14. 
TCELL, Cell temperature distribution for each Group.

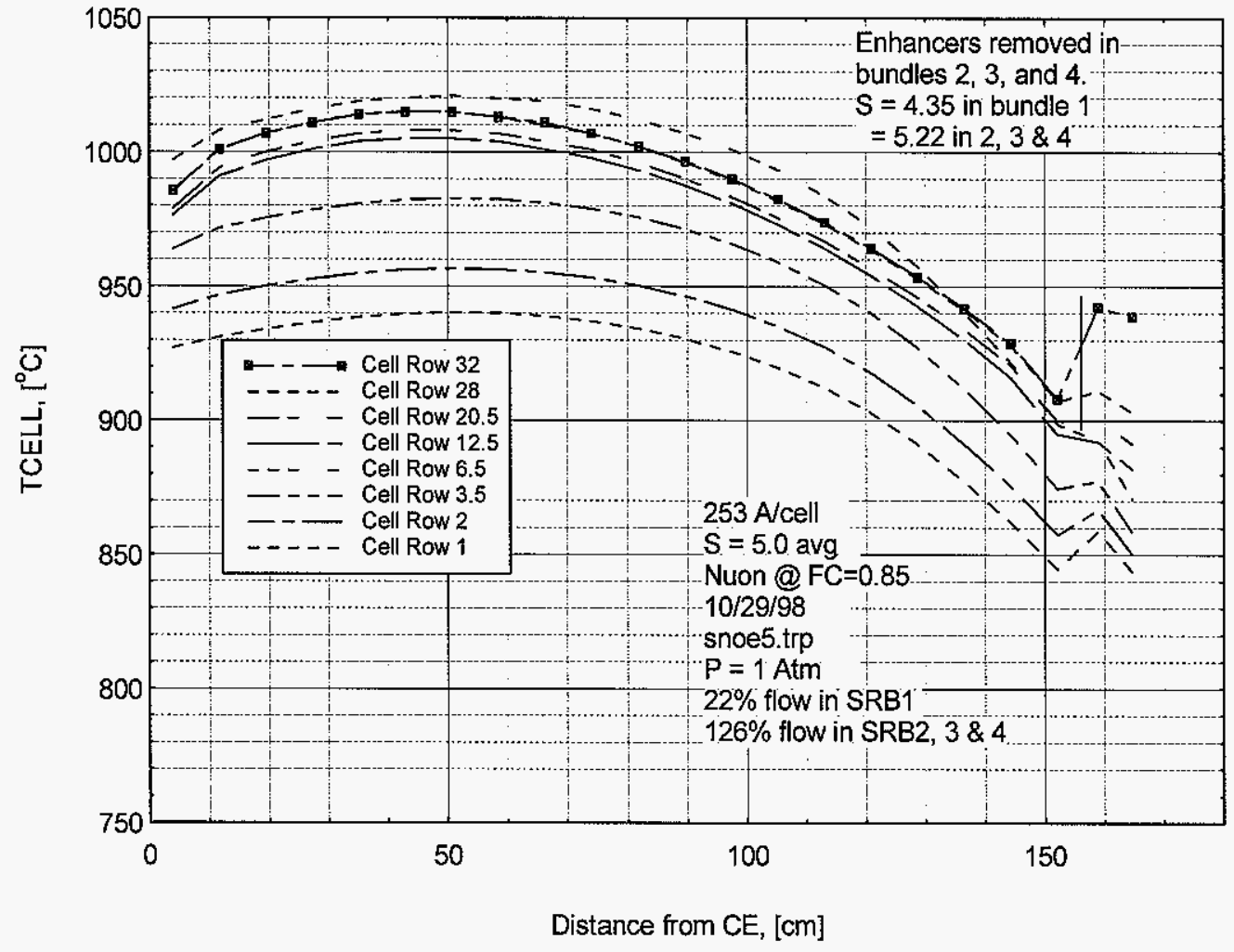

Figure 3-12 - Temperature profiles in staged-cell generator. 
Cell Voltage \& Avg T vs Cell Row Position

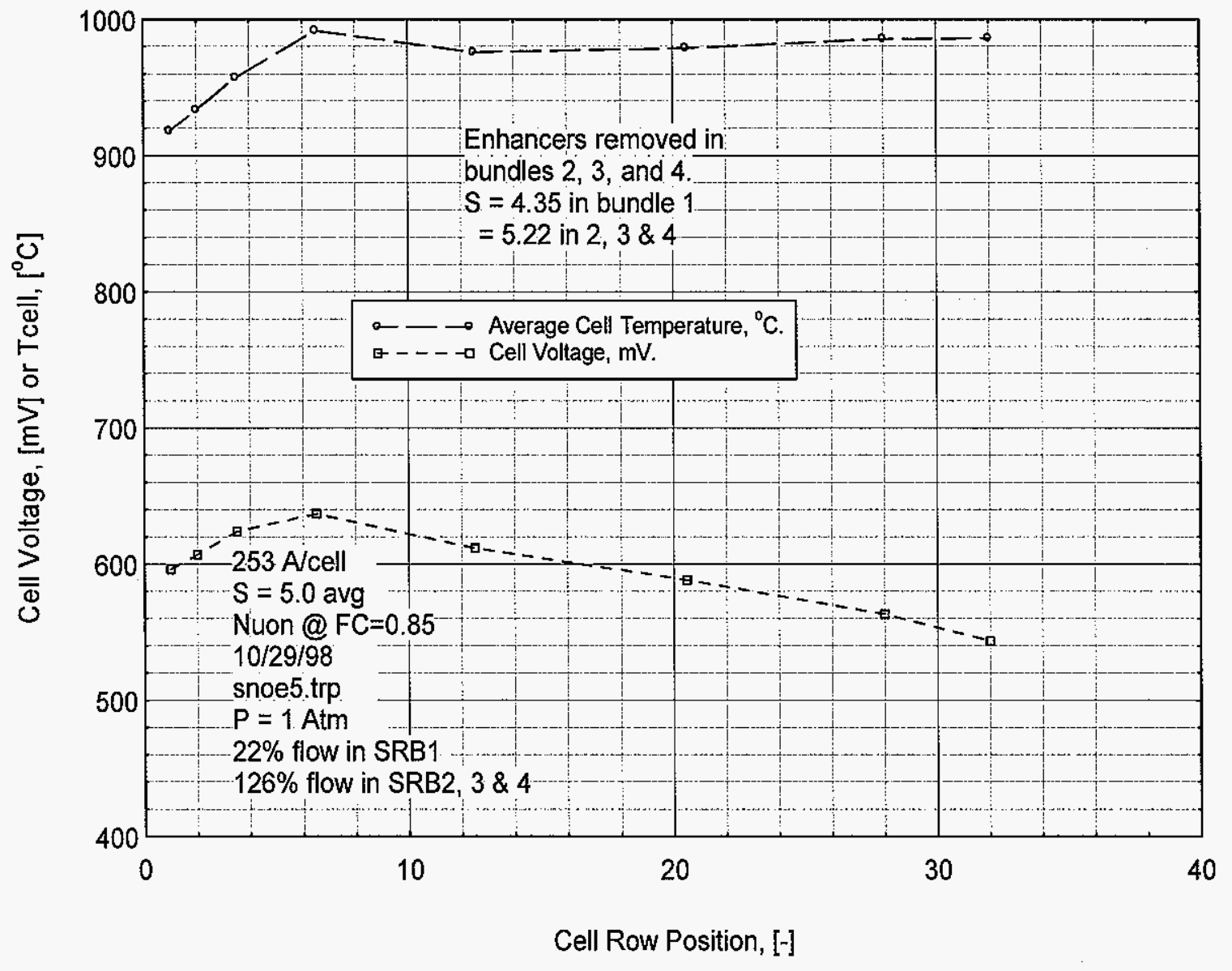

Figure 3-13 - Cell voltage and average temperature in a staged-cell generator. 
YFX, Fuel Mole fraction distr., exit each Group.

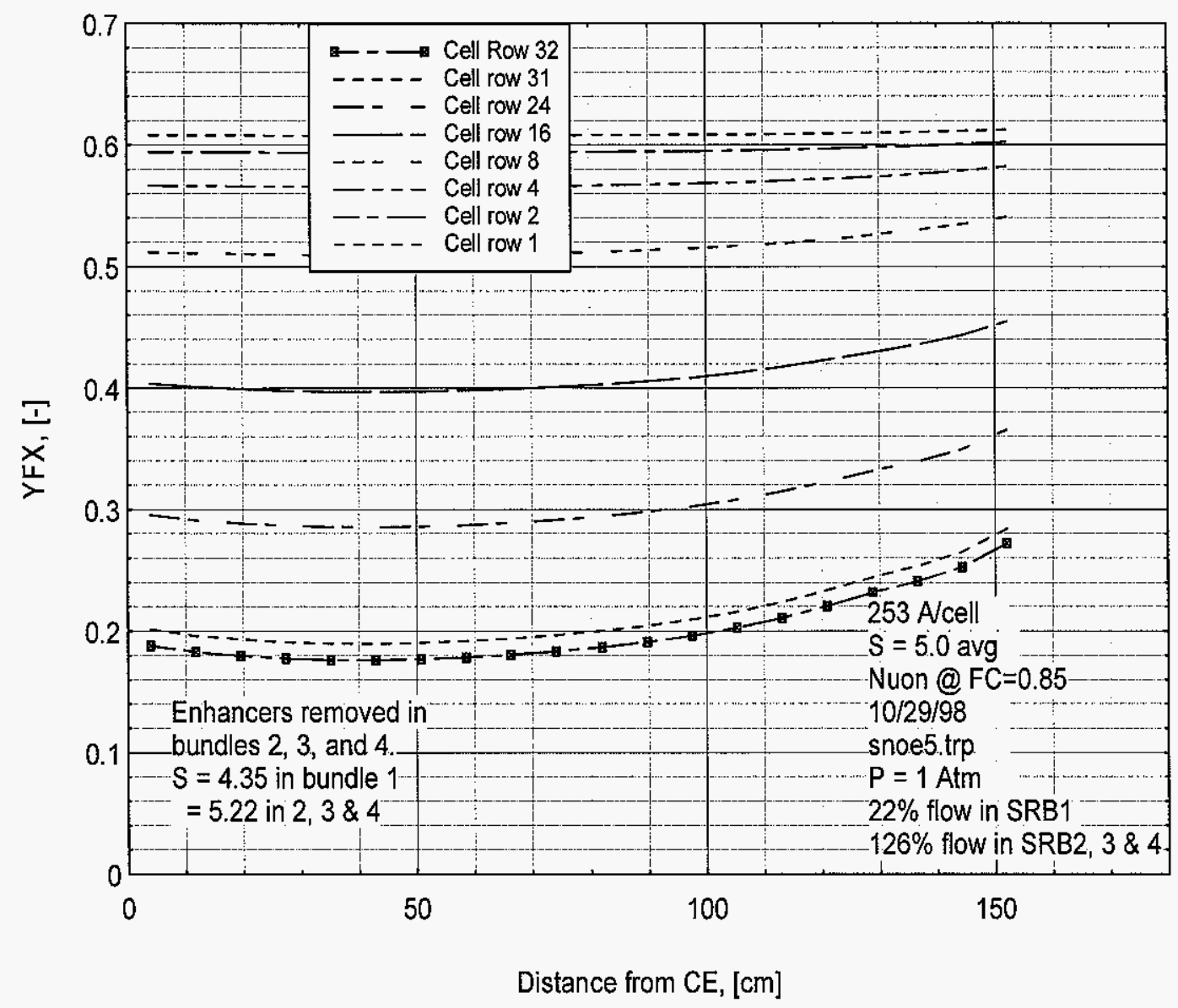

Figure 3-14 - Fuel mole fraction distribution in a staged-cell generator. 
The stack model modifications made significant improvements in the stack temperature uniformity, but the predicted performance of the cross-flow stack was still lower than for a conventional stack with the same maximum temperature limit. This result was obtained although several idealistic assumptions were made for the analysis which enhance performance relative to what would actually be expected. These assumptions included

1. The lateral heat losses at fuel inlet and exit were neglected. Including them would further reduce the temperature of the first cell rows.

2. It was assumed that the fuel mass flow rate was uniform per unit axial length of the cell and bypass of fuel at the inactive ends of the cells was neglected. Actual fuel flow through the central portions of the cells would be reduced due to the effect of higher temperature by the combined effects of low density and high viscosity. This is the same elevation where the current density - hence, fuel consumption, is higher than the average rate.

3. The influence of dimensional tolerances on fuel flow distributions was ignored. The actual fuel flow distribution would be sensitive to the lateral spacing between cells and to the cell-to-SRB gap.

Even with these assumptions, the fuel utilization in the staged cell design is limited due to the non-uniform consumption of fuel as it passes each cell. The fuel concentration at the exits of each stage at $92 \%$ fuel utilization is shown in Figure 3-15. In Figure 3-16, the partial pressure of $\mathrm{O}_{2}$ at the fuel electrode is compared to the equilibrium partial pressure of $\mathrm{O}_{2}$ for the $\mathrm{Ni} / \mathrm{NiO} / \mathrm{O}_{2}$ reaction. The comparison is made for the exit stage cell. Oxidation of the fuel electrode is likely whenever the $\mathrm{O}_{2}$ pressure is within two orders of magnitude of the equilibrium pressure. It is seen that this limit is exceeded for much of the cell length (data points are equally spaced). 


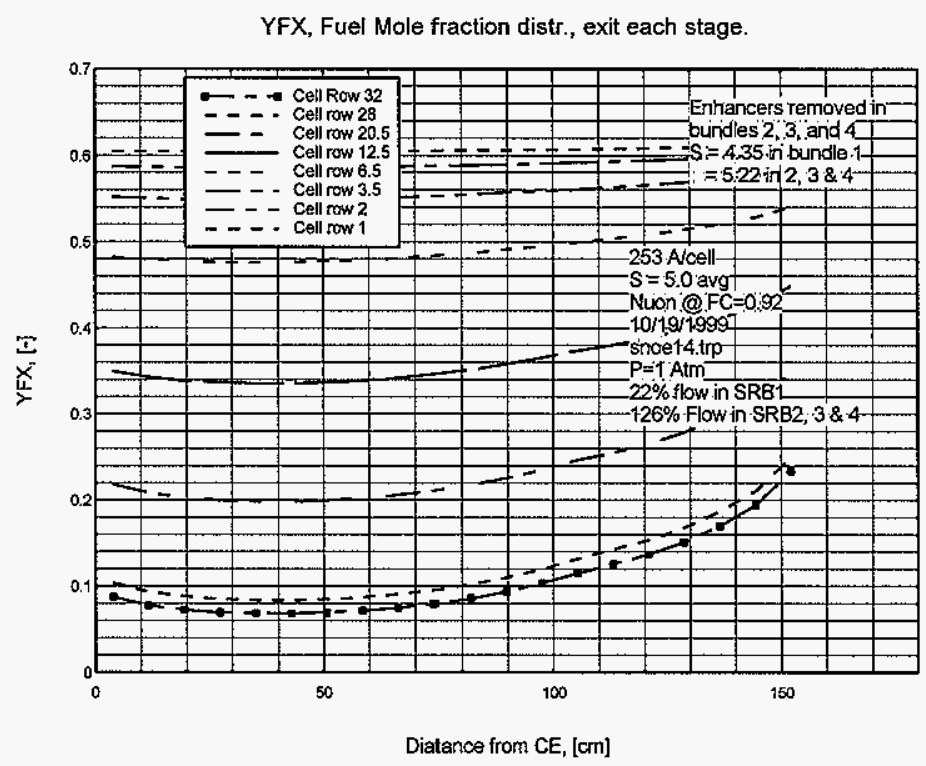

Figure 3-15 - Fuel concentration at the exit of each group of cells.

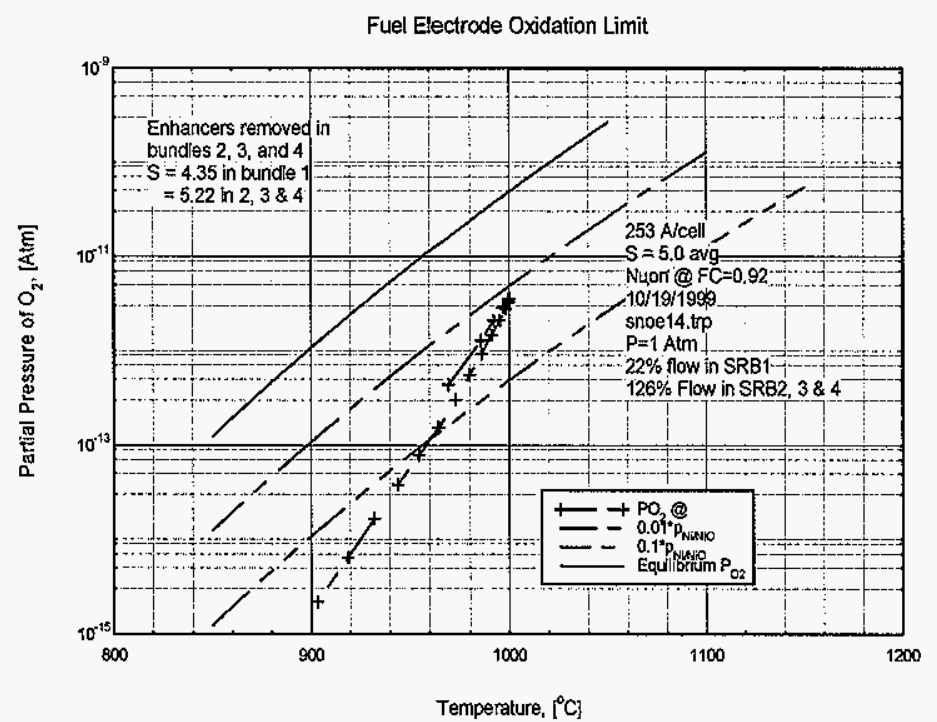

Figure 3-16 - Nickel fuel electrode oxidation limit - cross flow stack at FU $=92 \%$. 


\subsection{Summary of Staged-Cell Generator Concept Evaluation}

The conclusion from the isothermal model analysis in the Appendix is that there is only a small improvement in stack efficiency available due to cell staging at current densities near the point of maximum power. At the maximum power point, the improvement in power output due to staging is less than $0.6 \%$ for $85 \%$ fuel utilization, and less than $1.2 \%$ for $95 \%$ fuel utilization.

In the coupled model analysis the small benefits of staging were eroded by the effects of fuel cross flow on the overall stack temperature distribution. The inlet fuel for 32 cells impinges on each of the cells in sequence. This high flow of relatively cold fuel removes several times more heat from the first cell row than is generated. Radiation from the neighboring rows provides a large amount of heat but it is insufficient to achieve satisfactory temperatures in the first rows. A way to improve the effects of cold fuel would be to heat the fuel exiting from the SRBs. We were unable to find a reasonable way to effect heat exchange between the inlet fuel and a hotter exhaust stream without incurring significant pressure drops and complicating the stack design.

The previously assumed benefit of higher fuel utilization with a staged-cell concept was not available due to uneven consumption of fuel in the direction perpendicular to the fuel flow. Fuel was locally depleted to the point of fuel electrode oxidation before the fuel utilization reached $95 \%$ even with the optimistic fuel flow distribution assumptions used in the model. Due to this effect and to the cool-cell effect in the fuel-entry rows, it was concluded that the SOFC generator module design should retain the conventional cocurrent fuel flow and air flow configuration.

\subsubsection{SOFC Generator Design Description}

Much of the SOFC generator design philosophy and implementation is influenced by technology derived from two sources: the conventional $100 \mathrm{kWe}$ SOFC generator operating at atmospheric pressure and the pressurized SOFC generator in the $220 \mathrm{kWe}$ hybrid cycle power system which is designed to operate at 3 atmospheres.

The generator submodule design philosophy is an extrapolation of the current $200 \mathrm{kWe}$ SOFC generator configuration with the exception that the stacks are housed in a hori- 
zontal pressure vessel. Each stack assembly is installed on a common removable support structure lined with high performance thermal insulation.

This configuration greatly simplifies assembly of internal components by utilizing common parts and a modular, reusable insulation system.

The PSOFC generator design employs the air electrode supported (AES) fuel cell derived from the porous support tube (PST) cell. To date, PST test cells have achieved over 65,000 hours of operation. The AES fuel cell operating and durability history of over 32,000 hours reflects an improved design with significant advancements in material composition and processing.

Figure 3-17 shows a simplified array of closed tubular cells composed of concentric electrodes separated by a layer of solid electrolyte. Fuel for the electrochemical reaction flows upward between the tube exteriors, while process air flows upwards in the annular space between the air feed tube and the cell inner surface. Unreacted or spent fuel is burned above the bundles of tubes to preheat the incoming air. Nickel felt contacts provide flexible electrical connections between cells.

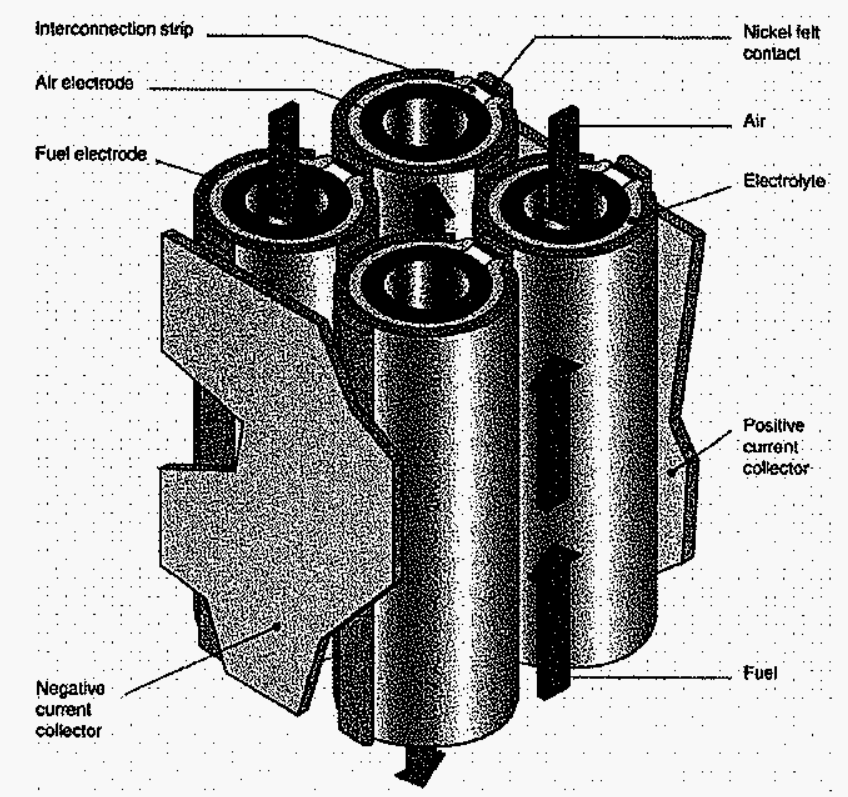

Figure 3-17 - Schematic fuel cell array. 
Each substack contains 576, $22 \mathrm{~mm}$ OD, $1500 \mathrm{~mm}$ active length tubular fuel cells, each capable of generating over 200 watts, arranged in 6 bundle rows. The cells are arranged in three parallel paths for improved reliability.

The submodule configuration is depicted in Figure 3-18. As shown, it includes ten fuel cell substacks, each fueled at the base by a fuel prereformer with integral fuel distribution manifolds and recirculation plenum, air manifold, DC power leads and stack internal insulation.

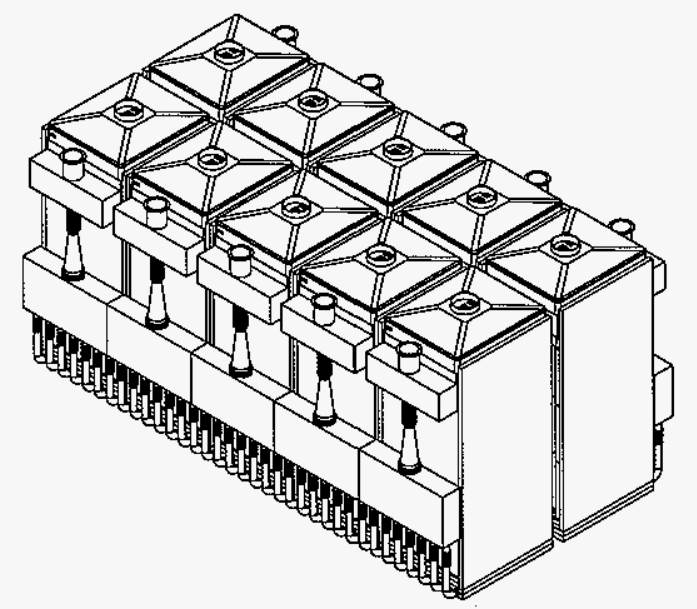

Figure 3-18 - Ten substacks isometric view.

Each substack is fed from a fuel supply system including a recirculation loop, ejectors, a prereformer and a fuel manifold with riser tubes. The recirculation plenum is used to mix the depleted fuel extracted from the stack with the fresh incoming fuel injected through an ejector nozzle. The mixture is then directed to a prereformer chamber where higher hydrocarbons are reformed to prevent carbon deposition in the stack reformers where full reformation of methane occurs. From the prereformer exit, the fuel mixture is distributed to each stack through a series of 7 bottom manifolds.

Process air is introduced into the submodule through one inlet nozzle connected to a centrally located air duct branching to individual smaller ducts feeding a large air plenum located on top of each stack. Each air plenum supplies air to 576 adjacent cells through ceramic air feed tubes. Air flows from the air plenum into the air feed tubes, which convey the oxidant to the lower, closed-end of each fuel cell. 
Exhaust from the substack is collected from side manifolds and ducted through larger side ducts terminating in a common transition fitting connected to the pressure vessel exhaust nozzle.

Fuel Cell Substack. The tubular SOFC cell features a porous air electrode made of doped lanthanum manganite ceramic material. A gas-tight electrolyte layer of yttriastabilized zirconia covers the air electrode, with the exception of an axial strip along the entire active length of the cell. This strip of bare air electrode material is covered by a thin, dense layer of doped lanthanum chromite. This layer, known as the cell interconnection, serves as the electric contact area to an adjacent cell or to a power contact. A top layer, the fuel electrode, is a nickel-zirconia cermet and covers the electrolyte surface except in the vicinity of the interconnection.

To construct an electric SOFC generator, individual cells are bundled into an array of electrically connected fuel cells, forming a monolithic structure that constitutes the basic generator stack.

The proposed fuel cell substack consists of a number of bundle arrays of $3 \times 8$ cells with an active (interconnection) length of $150 \mathrm{~cm}(59 \mathrm{in}$.$) . The cells are electrically intercon-$ nected in three parallel paths, each with 192 cells connected in series.

The three series-connected paths are intermittently connected by parallel shunts to improve reliability and gross electrical performance of the cell substack. An exploded view of the substack, as shown in Figure 3-19, is composed of 6 groups of cells, referred to as bundle rows, separated by electrically insulating in-stack reformers. Each bundle row includes 96 cells (three parallel paths of 32 series-connected cells).

These bundle rows are series-connected in a serpentine configuration and terminate at power take-offs that transfer current to the two opposite power leads. The metallic power leads may be air-cooled to withstand the high temperature environment surrounding the cell substack.

Each fuel cell substack is assembled externally on a common support structure prior to final installation into the pressure vessel. 


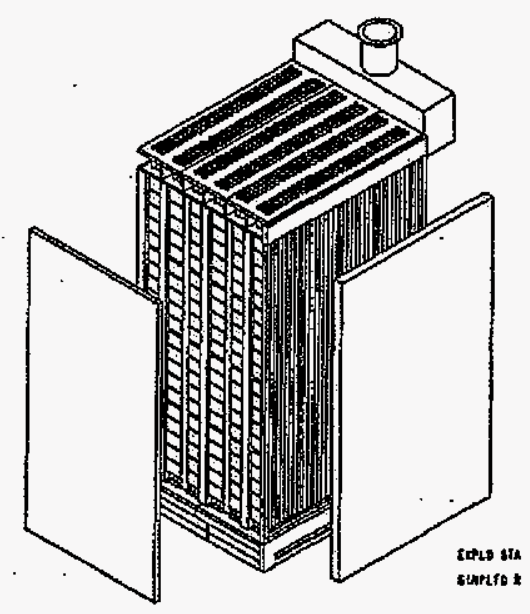

Figure 3-19 - Exploded view of 576-cell SOFC substack.

Stack Liner. Each cell substack is enclosed with a liner assembly composed by vertical panels made of Haynes 214 alloy foil, $0.25 \mathrm{~mm}$ (0.010 in.) thick, and each panel is joined full length by resistance or fusion welding process to form four individual subassemblies which are welded at the four corner seams.

The liner assembly incorporates a bottom metallic sealing with the lifting tray and the fuel manifold penetration sealing typical of the $220 \mathrm{kWe}$ PSOFC design. This type of design minimizes fuel leakage and it provides an effective barrier between the cell substack and the outer insulation made of low purity material.

Each panel includes a layer of "puff" board tiles bonded to the surface facing the substack. "Puff" boards are manufactured from layers of Saffil blanket material saturated with an organic binder and compressed to a $3.2 \mathrm{~mm}(0.125 \mathrm{in}$.) thickness to obtain the required density. During generator start up, the organic binder burns off and the Saffil layer is free to expand and fill the volume between the cell stack outer wall and the liner, thus preventing fuel bypass which may occur as a result of foil warpage under high temperature conditions. Each panel includes a series of "puff" board tiles, $305 \mathrm{~mm}$ (12 in.) wide, $406 \mathrm{~mm}$ (16 in.) high and $3.2 \mathrm{~mm}<0.125 \mathrm{in}$.) thick, glued to the stack with an organic adhesive.

Each liner panel includes two edge flexural flanges that are formed to a special shape designed to absorb thermal differential expansion of the panel in the direction normal to 
the flange length. The contour of the flexural flange is designed so that it achieves maximum displacement, minimum stress when the panels are welded side by side to form a complete subassembly; these multiple ribs produce a substantial stiffness and load capacity improvement in the direction of the ribs. The ribbed or corrugated sheet basically exhibits one way flexural behavior, since the perpendicular direction retains the properties typical of a flat plate.

Fuel Distribution System. The Fuel Distribution System includes fuel nozzle housing, a recirculation plenum system, ejector, prereformer and an array of tubular manifolds connected to vertical risers penetrating the SRB's assemblies. An isometric view of the Fuel Distribution System is shown in Figure 3-20.

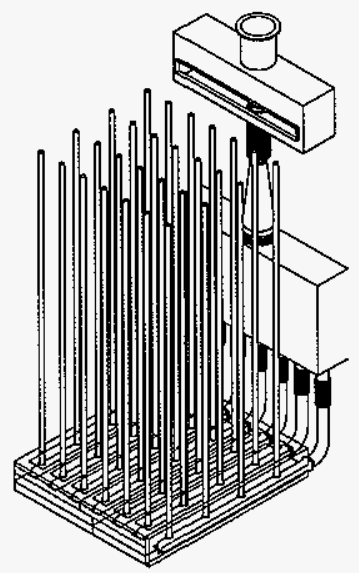

Figure 3-20 - Substack fuel distribution system.

Fresh fuel is injected through an ejector nozzle that entrains depleted gas extracted from the upper zone of the fuel cell substack. This fuel mixture is directed to a pre-reforming section where partial reformation occurs within a catalytic bed.

The fuel stream then exits the pre-reformer and is manifolded through a piping network connected to horizontal manifolds installed at the base of the substack. These manifolds are coupled at the periphery of the stack by a quick connect flange assembly.

Each manifold includes a number of vertical risers that direct the fuel to the top of the instack reformer internal cavity. The preponderance of fuel reformation occurs in this area and a hydrogen-rich stream is fed at the base of the stack to the exterior of the tubular fuel cells. Complete reformation is finally achieved at the closed end of the fuel cell. 
In-Stack Reformers. The in-stack reformer concept was developed to improve the SOFC system efficiency by reducing the airflow pumping requirements necessary to maintain cell axial temperature distributions within an acceptable range. Additionally, lower airflows reduce the required effectiveness (surface area) of the internal and external recuperators.

The SRB concept provides a large surface area for catalytic activity and heat transfer required for hydrocarbon reformation. It removes thermal energy uniformly along the entire cell length thereby resulting in sufficiently flat axial temperature distribution which helps to maintain acceptable axial temperature gradients within the substack. Moreover it has a much lower pressure drop than a conventional packed bed type external reformer.

The in-stack reformers each consist of a catalytically active inner assembly surrounded by a nickel foil liner, an outer board assembly and an embedded riser tube. Heat is radiated from the adjacent cell bundle region through the porous alumina outer board to supply the energy required for the endothermic reformation reaction.

As explained in the previous section, the in-stack reformers accomplish 85 to $100 \%$ of the reformation depending on the generator operating point.

The following is a summary of functional requirements of the in-stack fuel reformation system:

- control the cell axial temperature distribution to minimize voltage loss and maintain an acceptable axial temperature gradient.

- minimize the impact of prereformer catalyst replacement on system availability.

- provide adequate structural support for the upper air plenum and air feed tubes.

- assure electrical isolation to avoid insulation breakdown and short circuits within the stack at the maximum voltage potential in open circuit.

- maintain reformer pressure drop consistent with the capability of the recirculation ejector.

- maintain adequate fuel flow distribution uniformity within the cell stack.

- minimize stack plus reformer size and weight.

- minimize reformation cost. 
Air Supply System. Process air is introduced at the top of the generator submodule into an array of air plenums. Air flows from the air plenums into the air feed tubes, which are coaxial with the fuel cells and convey the air to the bottom of the cell. The air subsequently flows upward through an annulus between the feed tube and the cell inner surface.

Spent air exiting from the open end of the cells enters the combustion zone and reacts with spent fuel to completely consume the remaining fuel. Because the air feed tubes cross the combustion zone in a manner similar to a gas-to-air heat exchanger, incoming air is heated by the exhaust gas exiting the cell stack. The exhaust is directed to an upper dome prior to being manifolded to an external common exhaust duct.

High-pressure exhaust gas is collected from all submodules and is conveyed to the gas turbine through insulated piping. The turbine drives the compressor for compressing air that is delivered to the fuel cells.

Internal Thermal Insulation Package. To minimize heat losses from the SOFC stacks and at the same time maintain the pressure vessel wall temperature within reasonable limits, it is necessary to embed all the internals in thermal insulation without impairing the capability to easily service and replace internal components including the generator stack.

Typically, stack insulation within the stack liner is constituted by high purity alumina which exhibits excellent chemical stability at high temperature in both reducing and oxidizing atmosphere.

All elements of the stack insulation structure are typically vacuum formed by utilizing alumina fibers and binders in specific ratios to yield the desired thermal and mechanical properties. These elements include fuel manifold support boards, fuel distribution boards, in-stack reformer outer boards, stack end boards, lower/upper-positioning boards, recirculation and combustor boards.

The insulation package external to the stack liner consists of a number of highly efficient thermal insulation blocks and panels interlocked to form an effective thermal barrier system between the cell stack operating at $1000^{\circ} \mathrm{C}\left(1800^{\circ} \mathrm{F}\right)$ and the pressure vessel at ambient air. This insulation material is fitted between each substack and around all main manifolds and piping spool pieces. 
The insulation blocks and panels are constructed with silica material that has a microporous structure and is reflective to thermal radiation.

An additional layer of low density fiber material is installed between the ceramic cell stack and the composite blocks to form a compliant layer capable of accommodating cyclic thermal differential expansion while offering effective bypass gas sealing and adequate lateral load support.

PSOFC Module Description. The pressurized SOFC generator module includes twenty substacks (576 cells) electrically connected in series/parallel to the module terminals. Advantages of this type of construction include ease of assembly, flexibility in power output requirements, better serviceability and substack replacement capability.

The substacks are installed within a pair of horizontal pressure vessels containing a supporting structure designed to provide easy access to the internals and easy assembling and replacement of the submodules without interference with the installed internal components.

Pressure Vessel. The pressure vessel, as shown in Figure 3-21, is a horizontal cylindrical shell and is supported by two saddles anchored to the shipping container structural frame.

Pressure bearing components are required to meet construction codes such as the American Society of Mechanical Engineers (ASME) B31.1 piping code or the ASME Boiler and Pressure Vessel (BPV) Code. The allowable stresses for materials currently approved for construction under the rules of Sect. VIII, Div.1 of the ASME BPV Code are provided in various Code Cases or in Sect. II, Part D. 

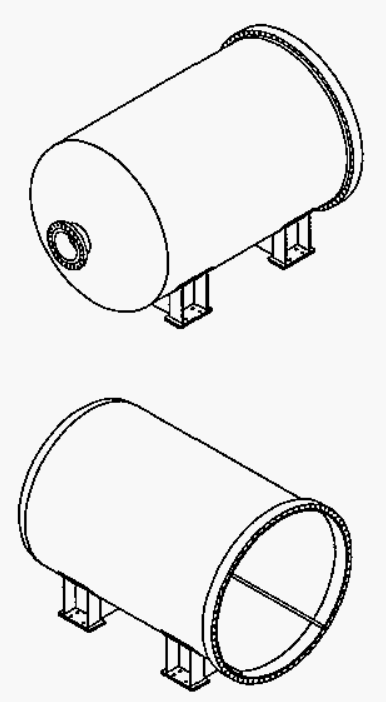

Figure 3-21 - Pressure vessel isometric views.

The design of the components is in compliance with the ASME BPV Code, Section VIII, Division 1. The cylindrical shell material is SA-516, Grade 70 carbon steel which provides a minimum tensile strength $480 \mathrm{MPa}(70,000 \mathrm{psi})$. The cylindrical shell thickness is determined by the tangential stress due to the design pressure. Since the maximum longitudinal stress $(P R / 2 t)$ is only half of the maximum tangential stress, one-half the shell thickness is available for the longitudinal bending stress due to weight at the midspan or in the plane of the saddles, assuming the vessel to behave as its own carrying beam.

As shown in Figure 3-21, two saddles including four legs and stiffener plates support the pressure vessel. The saddles are welded to the outer shell of the vessel with a 120degree contact angle, and they could be anchored to a concrete slab in the field. The saddle reactions are highly concentrated and induce localized stresses in the shell, which are within the allowable stress conditions specified by the ASME Code.

The ASME flanged and dished head is cold formed from the same material as the pressure vessel. Each head will include one large central air inlet or exhaust outlet nozzle and smaller penetrations for the electrical DC power leads or for internal instrumentation cables.

The shell flange as shown in Figure 3-21, has an outer diameter of approximately $3.5 \mathrm{~m}$ (137 in.) and a length through the hub of $280 \mathrm{~mm}$ (11 in.) and is forged from SA-105 carbon steel material. Seventy-two $38 \mathrm{~mm}$ (1.5 in.) diameter radial holes are drilled through 
the flange for the bolts. The overall weight of each flange is approximately $2450 \mathrm{~kg}$ (5400 lb).

Bolting material for pressure connections must conform to the specifications listed in the ASME Code. Specifically, for this design, SA-193 Grade B7 (1 Cr-1/5 Mo) ferritic steel bolts have been selected. To minimize galling when the bolts are tightened, fasteners are made up with a thread lubricant such as Molykote paste. The proposed bolting configuration includes 72 bolts with a $35 \mathrm{~mm}$ (1.4 in.) bolt diameter in a bolt circle of $3.4 \mathrm{~m}$ (134 in.).

Two of these pressure vessels bolted together at their flanges, as shown in Figure 3-22, form the vessel for a single PSOFC generator module.

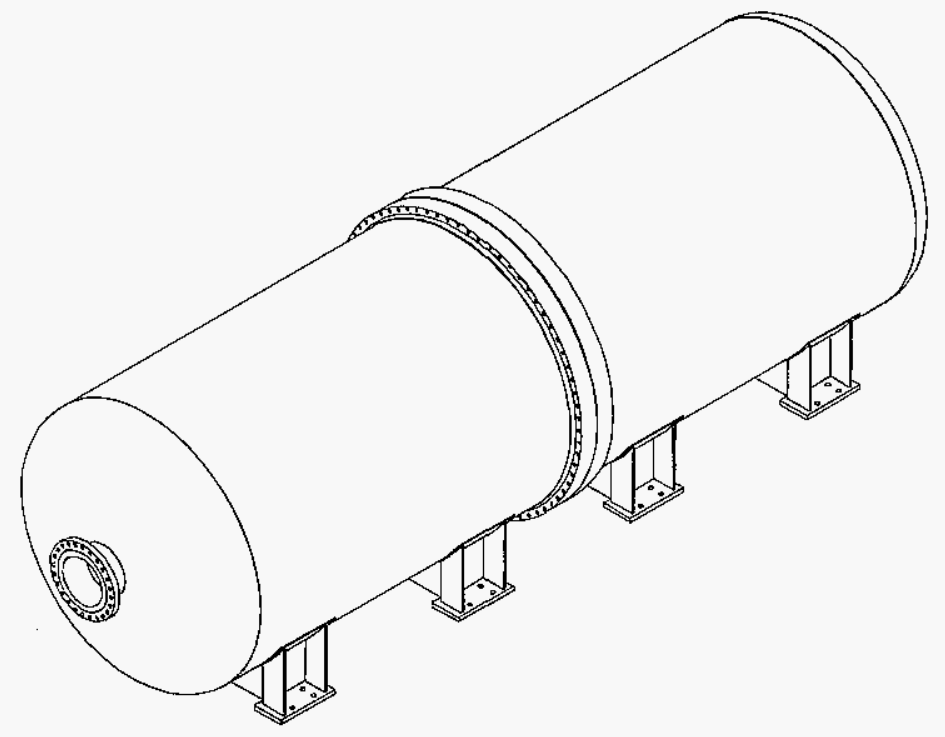

Figure 3-22 - PSOFC generator module isometric view.

A detail drawing of the pressure vessel and associated Bill of Materials is shown in Figure 3-23. 


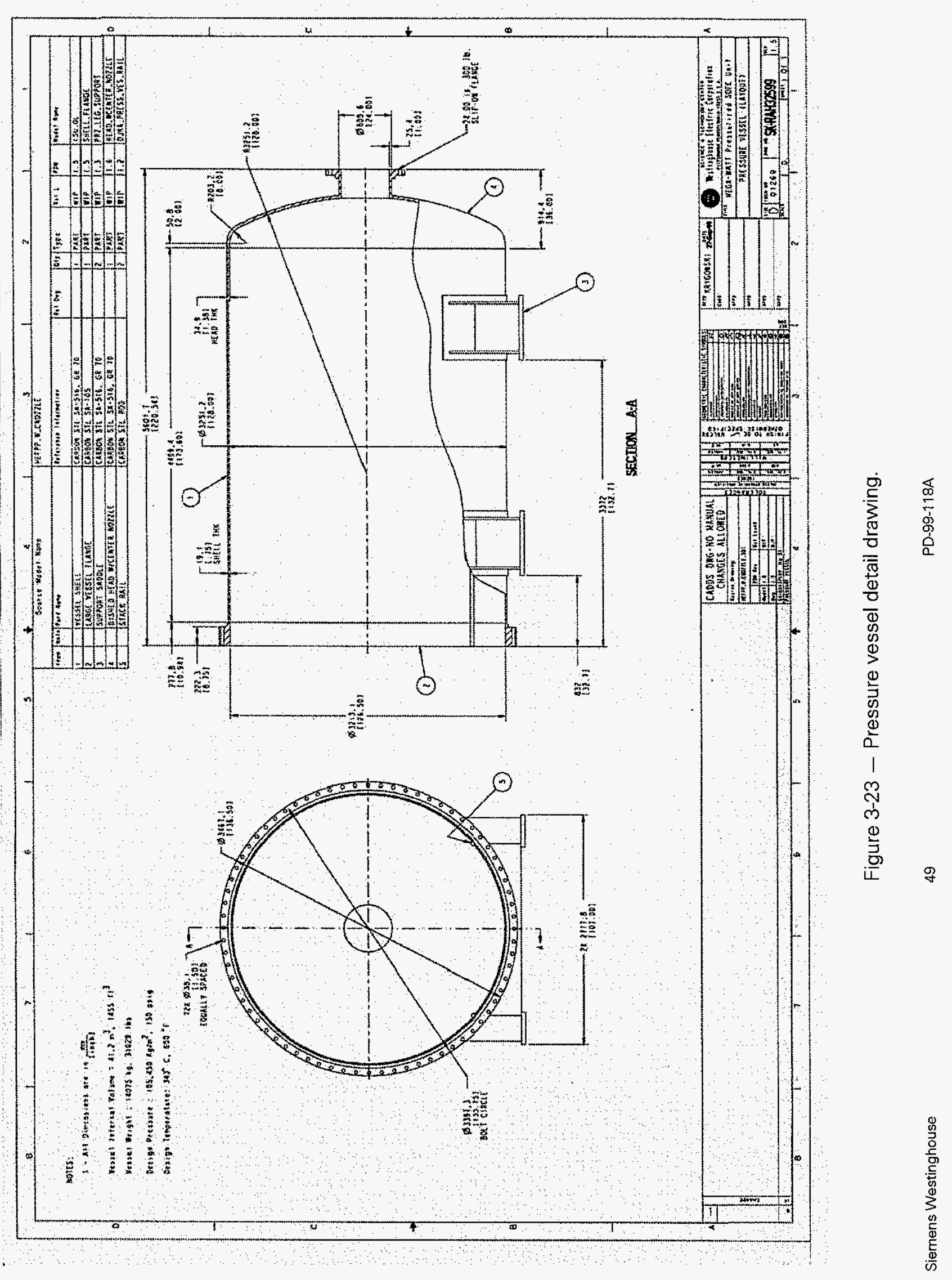


Internal Sub-module Supporting Structure. As shown in Figure 3-24, the pressure vessel incorporates internally a supporting structure that is embedded in high temperature insulation material. This supporting structure is composed by two tubular steel side members separated by a series of equally spaced high density ceramic boards over which a steel deck is finally installed.

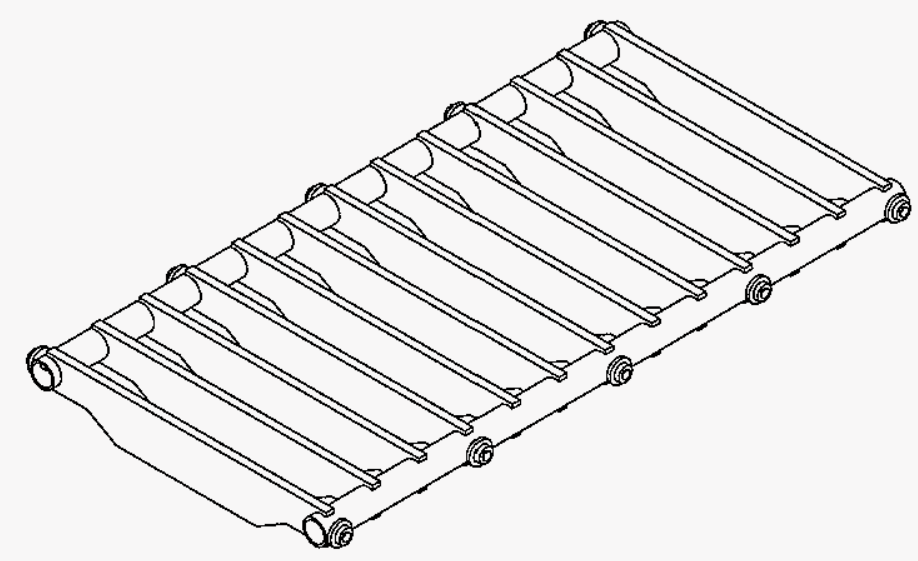

Figure 3-24 - Stack support car.

The tubular members include a series of high temperature roller assemblies including a wheel, axle box; die steel caged roller bearing and high load rating axle. These wheel assemblies are typically used in furnace and kiln cars for a variety of heat treatment processes.

This rolling structure provides a convenient open deck for stack assembly, support for piping, ducting and electrical instrumentation without interfering with the assembly/disassembly of the stacks. Once the internals are fully assembled on the support structure, the entire assembly is rolled into the pressure vessel over two rails welded to the shell wall. Once in position, the wheels are locked and secured.

This method of supporting and transporting the stack submodules is particularly advantageous for in-situ stack replacements or quick field installation in the event that the pressure vessels are procured locally or are already installed at the power plant.

A complete assembly of the module internals, including the SOFC stacks, ducting and supporting structure is shown in Figure 3-25. 


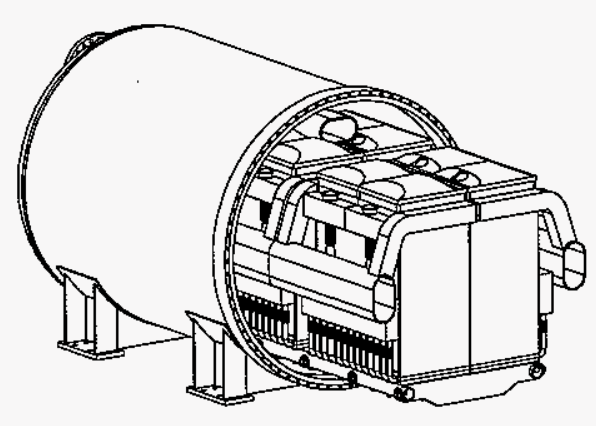

Figure 3-25 - Isometric view of module with internal components.

Internal Air/Exhaust Ducting. When the substacks are inserted and positioned within the pressure vessel, they are connected to a common central air feed manifold by utilizing individual spool pieces connected to the inlet nozzle of each substack. The central manifold uniformly distributes the incoming pressurized process air to the individual substacks. The air manifold is positioned longitudinally within the pressure vessel, is supported by the ceramic frames and is embedded in the same insulation material surrounding the supporting structure. The final connection of the air manifold is made in correspondence to the side flanged cover nozzle through an expansion joint/adapter.

The exhaust gas flow from each substack is directed to an exhaust collecting plenum overhanging each substack and is subsequently manifolded into a central duct exiting through the exhaust outlet nozzle.

The air ducting operates at a maximum temperature of $760^{\circ} \mathrm{C}\left(1400^{\circ} \mathrm{F}\right)$ and the exhaust ducting temperature does not exceed $870^{\circ} \mathrm{C}\left(1600^{\circ} \mathrm{F}\right)$. Because the internal differential pressure between process air and exhaust is less than 60 mbar $(0.9$ psi $\}$ as a result of only frictional losses and generator pressure drop, ducting rather than piping is utilized internally. Externally, all piping is fabricated to withstand a 10 barg (150 psig) design pressure.

Fuel Inlet Piping. The fuel inlet piping will operate at a pressure of 3.5 to 5 bar ( 50 to $70 \mathrm{psi}$ ) differential inside the pressure vessel and up to 12 to $14 \mathrm{bar}$ (180 to $200 \mathrm{psi}$ ) externally. The final pressure will be determined on the basis of the selected generator operating range, fuel composition and gas turbine selection. 
Electrical Interconnections. Internal electrical interconnections between stacks are accomplished through utilization of a main DC bus bar and flexible cable connectors clamped to each stack power lead.

High reliability electrical feed-throughs are utilized on the pressure boundary of the module in order to guarantee sound electrical connection between the internal stacks and the external power conditioning system.

Generator Instrumentation. The SOFC generator module is equipped with a variety of instrumentation providing for automatic control with manual capability for plant operation, monitoring and diagnostics.

The generator stack instrumentation consists primarily of DC voltage taps and cell stack thermocouples. Within the cell stack, there are a number of voltage taps monitoring the progressive buildup of accumulated cell voltages with the first tap near ground potential and the last at the maximum DC voltage. The stack external terminal voltage is also monitored as well as the main generator module terminals.

Several thermocouples are embedded within each cell stack at different elevations to monitor and control the temperature of the generator stack.

A number of pressure taps may be included into each stack fuel supply system to monitor differential pressures around the fuel ejector systems and to provide gas sampling as required.

\subsubsection{Gas Turbine System - Caterpillar Solar Turbines Mercury ${ }^{\mathrm{TM}} 50$}

\subsubsection{Integration of Mercury ${ }^{\mathrm{TM}} 50$ to PSOFC/ATS-GT System}

\section{INTRODUCTION}

Selection and integration of a well matched gas turbine engine to the pressurized solid oxide fuel cell subsystem is a key factor in determining the lowest COE integrated system. The Caterpillar Solar Turbines Mercury ${ }^{\mathrm{TM}} 50$ recuperated gas turbine engine was chosen as the gas turbine to integrate in this lowest cost of electricity PSOFC/ATS-GT concept system. See Figure 3-26, Figure 3-27, and Figure 3-28. 


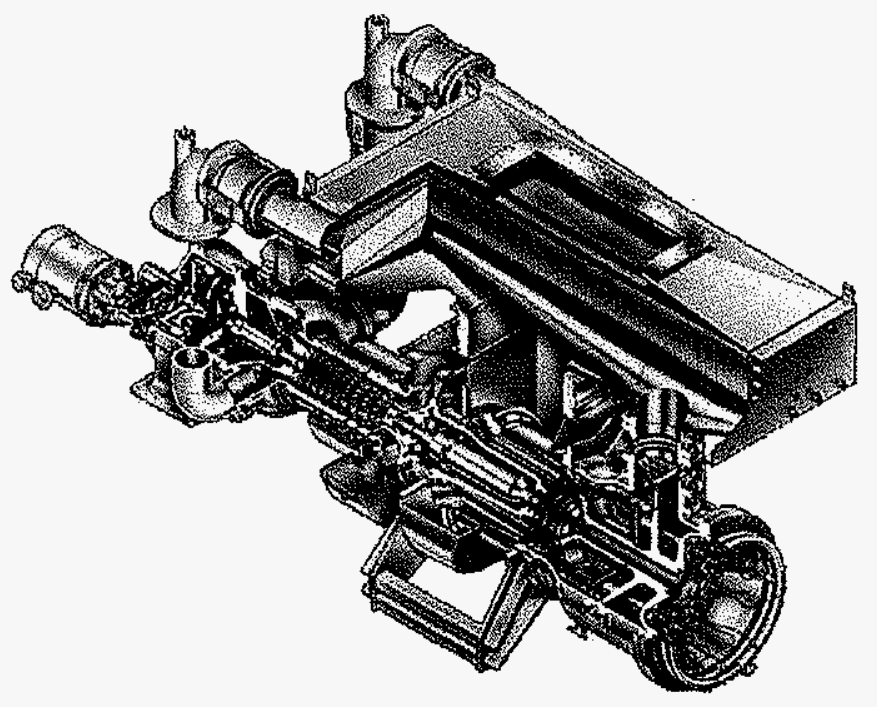

Figure 3-26 - Mercury ${ }^{\mathrm{TM}} 50$ recuperated gas turbine, pictorial view.
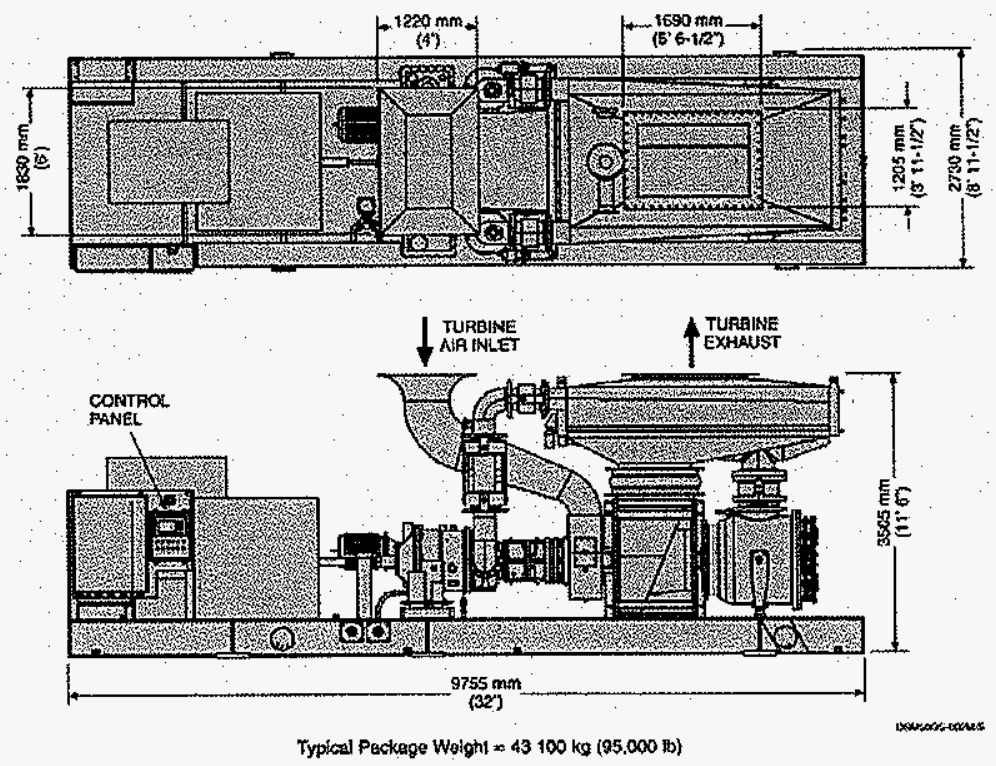

Figure 3-27 - Mercury $^{\mathrm{TM}} 50$ recuperated gas turbine, plan and elevation views. 


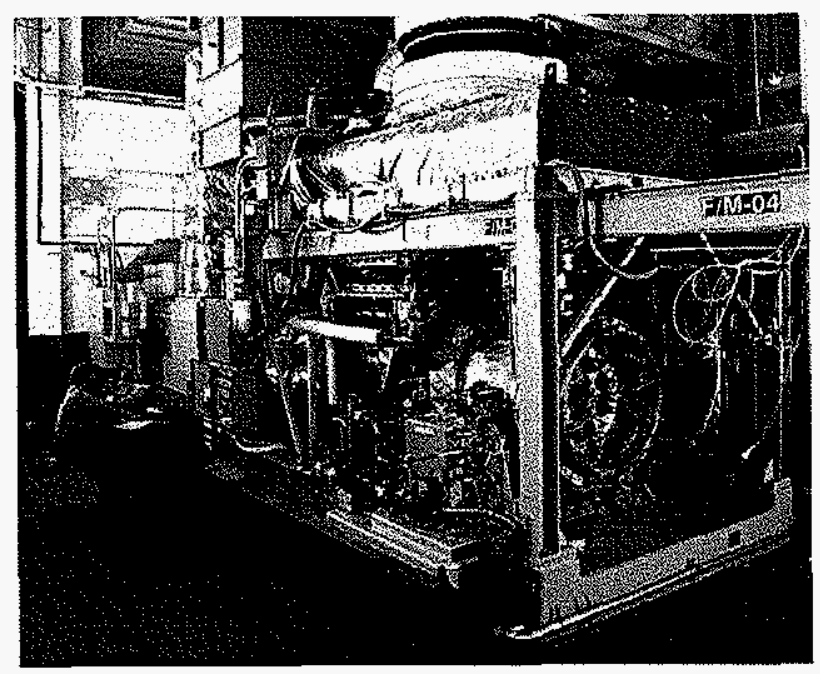

Figure 3-28 - Mercury ${ }^{\mathrm{TM}} 50$ turnkey system test at solar turbines, San Diego, California.

The Mercury ${ }^{\mathrm{TM}} 50$ gas turbine was chosen due to its high thermal efficiency, power rating, modular design, reliability, and low cost of maintenance. The design point specifications and pertinent fuel cell integration points of the Mercury ${ }^{\mathrm{TM}} 50$ as a stand alone gas turbine engine at 80 and $59^{\circ} \mathrm{F}$ ambient, sea level conditions are as follows:

\begin{tabular}{|l|c|c|}
\hline \multicolumn{1}{|c|}{ Parameter } & & \\
\hline Ambient Air Temperature, ${ }^{\circ} \mathrm{C}\left({ }^{\circ} \mathrm{F}\right)$ & $27(80)$ & $15(59)$ \\
\hline Turbine Electric Power, MWe & 4.21 & 4.57 \\
\hline Overall Efficiency- Generator Busbar, \% & 40.0 & 41.5 \\
\hline Natural Gas Fuel Flow, $\mathrm{kg} / \mathrm{h}(\mathrm{lb} / \mathrm{h})$ & $791(1742)$ & $828(1823)$ \\
\hline Overall Airflow, $\mathrm{kg} / \mathrm{s}(\mathrm{lb} / \mathrm{s})$ & $16.0(35.3)$ & $16.6(36.5)$ \\
\hline Compressor Pressure Ratio & 9.25 & 9.33 \\
\hline Recuperator Airflow, $\mathrm{kg} / \mathrm{s}(\mathrm{lb} / \mathrm{s})$ & $15.5(34.2)$ & $16.0(35.3)$ \\
\hline Recuperator Air Outlet Temperature, ${ }^{\circ} \mathrm{C}\left({ }^{\circ} \mathrm{F}\right)$ & $631(1168)$ & $621(1149)$ \\
\hline Recuperator Air Outlet Pressure, bara $(\mathrm{psia})$ & $8.8(127.5)$ & $9.1(131.8)$ \\
\hline
\end{tabular}


The performance quoted is based on the following component parameters:

\begin{tabular}{|l|c|}
\hline \multicolumn{1}{|c|}{ Parameter } & \\
\hline Generator Efficiency & $97.0 \%$ \\
\hline Gearbox Efficiency & $98.7 \%$ \\
\hline Fuel LHV & $20,610 \mathrm{Btu} / \mathrm{b}$ \\
\hline Inlet Air Relative Humidity & $60 \%$ \\
\hline Compressor Inlet Delta P & 0 \\
\hline Exhaust Delta P & $3.8 \%$ \\
\hline Compressor Pressure Ratio & 9.33 \\
\hline Combustor Outlet Temp & $1208^{\circ} \mathrm{C}\left(2206^{\circ} \mathrm{F}\right)$ \\
\hline Combustor TRIT & $1163^{\circ} \mathrm{C}\left(2125^{\circ} \mathrm{F}\right)$ \\
\hline Compressor Flow & $16.7 \mathrm{~kg} / \mathrm{s}(36.5 \mathrm{lb} / \mathrm{s})$ \\
\hline Recuperator Gas Flow & $16.8 \mathrm{~kg} / \mathrm{s}(36.9 \mathrm{lb} / \mathrm{s})$ \\
\hline Fuel Added & $0.23 \mathrm{~kg} / \mathrm{s}(0.5 \mathrm{lb} / \mathrm{s})$ \\
\hline Air Lost & $0.09 \mathrm{~kg} / \mathrm{s}(0.2 \mathrm{lb} / \mathrm{s})$ \\
\hline Combustor DP/P & $3.0 \%$ \\
\hline Compressor Adiabatic Eff & $87.5 \%$ \\
\hline Expander Adiabatic Eff & $87.6 \%$ \\
\hline Recuperator Effectiveness & $92 \%$ \\
\hline Recuperator Air Out Temp & $621^{\circ} \mathrm{C}\left(1149^{\circ} \mathrm{F}\right)$ \\
\hline
\end{tabular}

The list price of the Mercury ${ }^{\mathrm{TM}} 50$ gas turbine engine in 1999 US dollars is $\$ 1,950,000$ for the base engine and $\$ 2,450,000$ for a complete turnkey system. The total maintenance cost of the Mercury ${ }^{\mathrm{TM}} 50$ system is $\$ 0.00377 / \mathrm{kW}-\mathrm{hr}$. The price of the Mercury ${ }^{\mathrm{TM}} 50 \mathrm{in}$ cludes $\$ 250,000$ required to integrate the engine to the pressurized, solid oxide fuel cells and modification to the combustor subsystem, especially modifications required in high temperature materials and insulation required of the higher $870^{\circ} \mathrm{C}\left(1600^{\circ} \mathrm{F}\right) \mathrm{com}$ bustor air inlet temperature.

Modifications to Mercury ${ }^{\mathrm{TM}}$ 50. The combined Mercury ${ }^{\mathrm{TM}} 50$ / PSOFC system was optimized by Siemens Westinghouse with input from Caterpillar Research regarding the Mercury ${ }^{\mathrm{TM}} 50$ performance. The combined PSOFC/ATS-GT system optimized for the lowest cost of electricity resulted in the Mercury ${ }^{\mathrm{TM}} 50$ turbine operating very near its $59^{\circ} \mathrm{F} / \mathrm{sea}$ level design point. The lowest COE point resulted in the Mercury ${ }^{\mathrm{TM}} 50$ running at a pressure ratio of $9.5: 1$ versus a design point of 9.3:1 which resulted in a power output of 4.8 MWe versus a design point of 4.6 MWe. A minor adjustment to the compressor variable geometry opening stators 5.7 degrees was required to rematch the Mercury $^{\mathrm{TM}} 50$ to the integrated PSOFC/ATS-GT optimum point. Combustor outlet TRIT 
was maintained at $1163^{\circ} \mathrm{C}\left(2125^{\circ} \mathrm{F}\right)$ with overall thermal efficiency of the engine dropping only 0.5 point.

The combustor will be receiving airflow from the PSOFC generator modules, containing approximately $16 \%$ oxygen, at $870^{\circ} \mathrm{C}\left(1600^{\circ} \mathrm{F}\right)$ versus an engine design point airflow temperature from the recuperator of $621^{\circ} \mathrm{C}\left(1149^{\circ} \mathrm{F}\right)$. The eight injectors of the combustion system shown in Figure 3-29 and Figure 3-30 will need to be resized to maintain the proper optimum combustion characteristics; however, the combustor is required to raise the engine flow $318^{\circ} \mathrm{C}\left(605^{\circ} \mathrm{F}\right)$ versus a normal temperature rise of $586^{\circ} \mathrm{C}\left(1056^{\circ} \mathrm{F}\right)$ for the base Mercury ${ }^{\top M} 50$ engine design point on a $15^{\circ} \mathrm{C}\left(59^{\circ} \mathrm{F}\right)$ day. Modifications to the combustor main case would need to take place to be able to withstand the $870^{\circ} \mathrm{C}$ $\left(1600^{\circ} \mathrm{F}\right)$ PSOFC exhaust. Incorporating internal insulation, similar to that used in the PSOFC exhaust piping, would be the prime path; however, redesign of the combustor case using high temperature materials should be investigated in any future design.

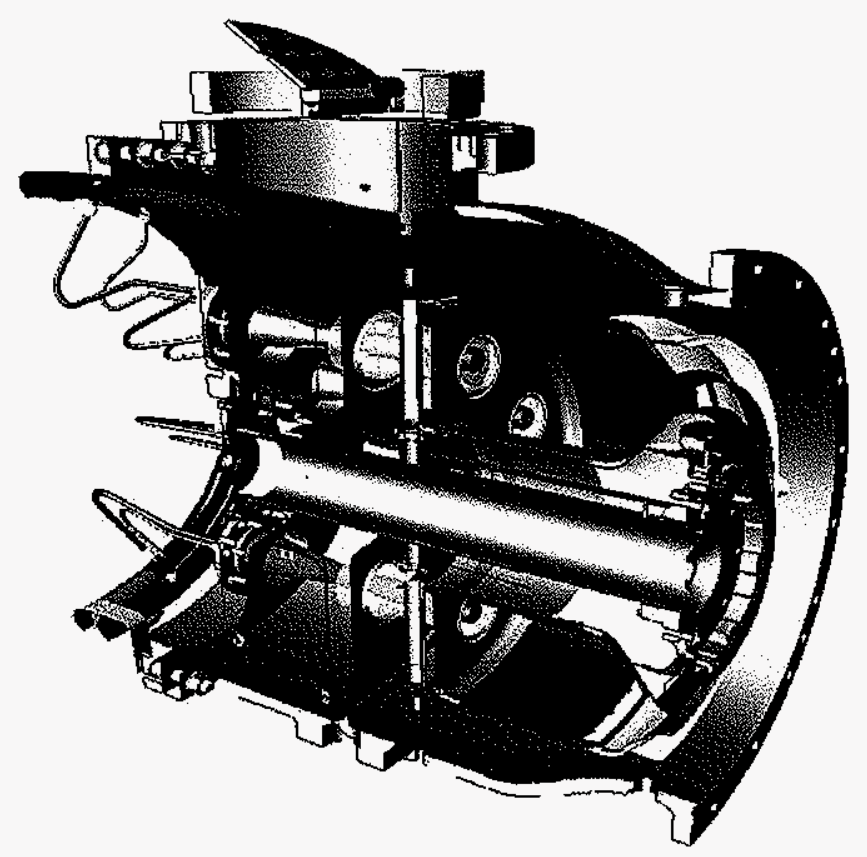

Figure 3-29 - Mercury ${ }^{\mathrm{TM}} 50$ combustor. 


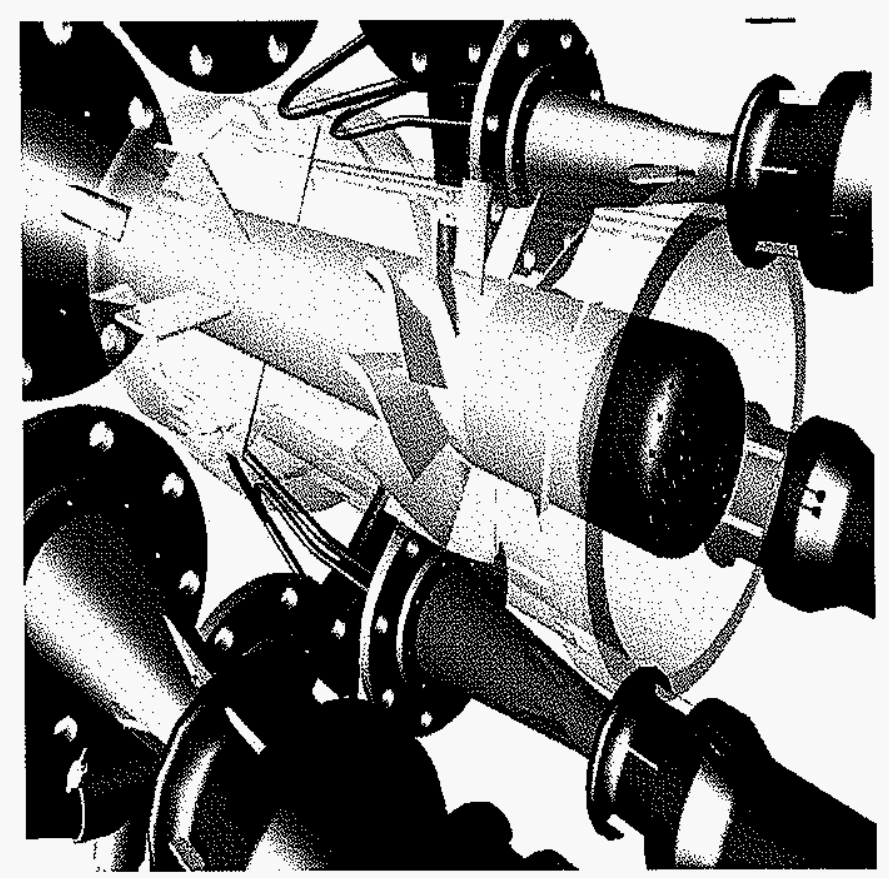

Figure 3-30 - Mercury ${ }^{\mathrm{TM}} 50$ injectors.

Physically, with the combustion section at one end of the engine, the modular and innovative design of the Mercury ${ }^{\mathrm{TM}} 50$ facilitates the easy integration of the engine with the PSOFC system. As shown in Figure 3-26, the Mercury ${ }^{\mathrm{TM}} 50$ normally has a single connection between the recuperator air outlet and the combustor at the 12 o'clock position. The recuperator air outlet will be extended axially outward for connection with the air heater inlet and the turbine combustor section will be rotated 90 degrees for easy connection with the PSOFC exhaust as depicted in Figure 3-31. As conceived, these combustor modifications are expected to increase the price of the Mercury ${ }^{\mathrm{rM}} 50$ engine by US $\$ 250,000$. 


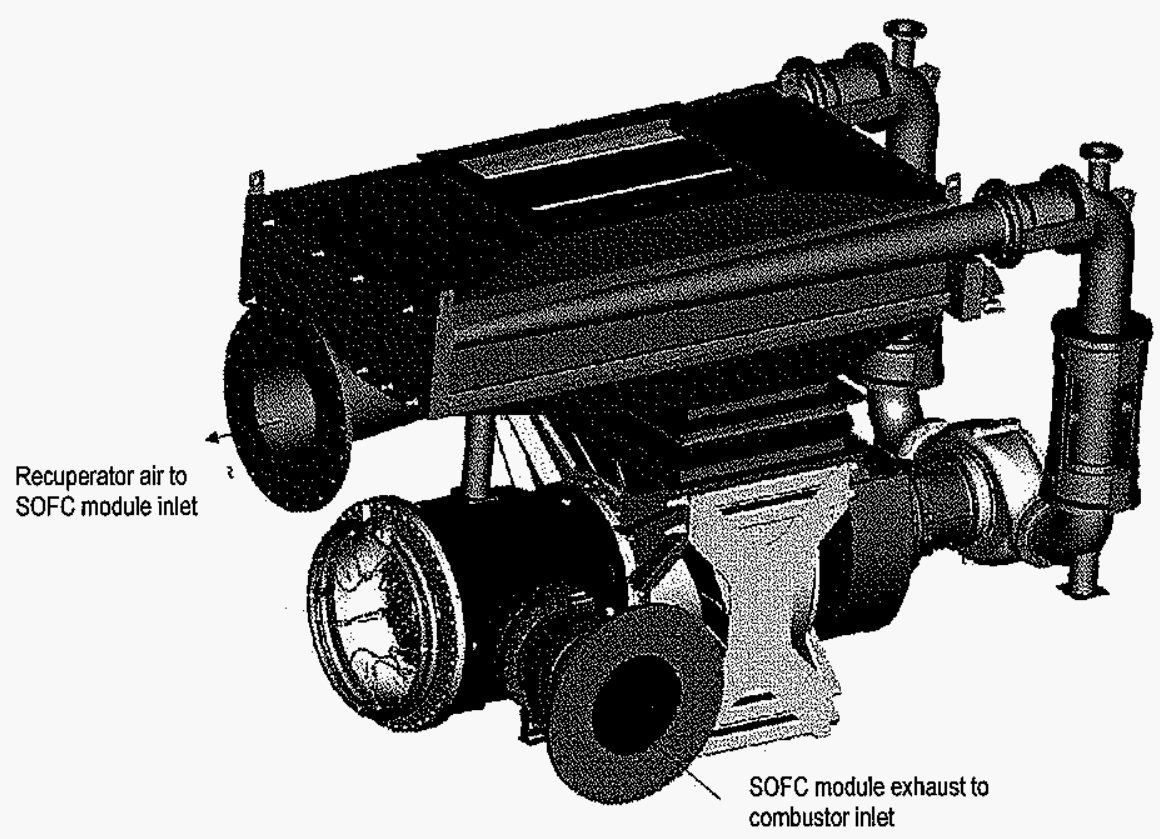

Figure 3-31 - Modifications required for PSOFC integration.

\subsubsection{Mercury ${ }^{\top \mathrm{M}} 50$ Recuperated Turbine Engine Background}

In recognition of the fact that gas turbines are playing an increasingly important role in power generation, the U.S. Department of Energy (DOE) is supporting the development of advanced, land-based gas turbine systems that meet stringent emissions requirements while significantly increasing fuel efficiency. Notable exceptions notwithstanding, government support has been largely absent from industrial turbine development activities to date. The consequences of this absence have essentially been twofold: 1$)$ product development activities that are almost exclusively market-driven; and 2) limited incremental improvements to the underlying technology. The financial underwriting that comes from government support of development activities frees companies to pursue step improvements in the underlying technology with-out unduly risking profitability in the process.

The ATS concept was jointly created by the DOE and the industrial turbine industry to develop highly efficient, environmentally superior gas turbine systems for both utility and industrial power generation applications. By co-developing a set of symbiotic goals between the government and industry at the onset of the program, the ATS program has secured strong support from both the public and private sectors. As a result, the pro- 
gram has come to represent one of the most successful government/industry partnerships in recent years, one in which both the public and private sectors will realize significant returns on their collective investment. This section of the report defines the ATS program and product goals, and explains Solar's involvement as well as the salient details of the Mercury ${ }^{\mathrm{TM}} 50$ gas turbine and package design.

\section{PROGRAM GOALS}

The stated objectives of the industrial ATS program are a joint representation of the societal goals of government combined with the economic goals of the commercial marketplace (U.S. DOE, 1994), involving efficiency, environment, fuel flexibility, cost of power, and reliability and maintainability. These goals are based on quantitative improvements relative to the markets and systems available in 1991.

Efficiency. A 15 percentage point improvement in the efficiency of the gas turbine system compared to the best technology in its class that is available in the market (1991). The efficiency is based on the lower heating value (LHV) of natural gas.

Environment. Environmental superiority under full and part-load operating conditions without the use of post-combustion controls. Oxides of nitrogen (NOX), carbon monoxide $(\mathrm{CO})$ and unburned hydrocarbon (UHC) emissions will be lowered to achieve acceptance in severe non-attainment areas.

Fuel Flexibility. Natural gas fired ATS systems are to be adaptable to future firing with biomass and coal-derived fuels.

Cost of Power. Busbar energy costs at $10 \%$ less than current state-of-the-art turbine systems (1991) meeting the same environmental requirements.

Reliability and Maintainability. Equivalent to current state-of-the-art turbine systems (1991).

The DOE's offices of Fossil Energy, Energy Efficiency and Renewable Energy are jointly responsible for the ATS program. Management of the program is coordinated with the Environmental Protection Agency, the Electric Power Research Institute, the Gas Research Institute, gas turbine manufacturers, the DOE and others. The ATS program was developed in response to the Energy Policy Act of 1992 and outlines an eight year, fourphase timetable. Supporting research, development and evaluation of key enabling 
technologies is being carried out via a university consortium, consisting of more than 40 colleges and universities across the United States, coordinated and administered by the South Carolina Energy Research and Development Center at Clemson University under the ATS umbrella.

Since the industrial and utility markets are distinctly different in terms of users and marketplace requirements, the ATS program has been segregated into two separate elements to independently address these needs. Industrial gas turbine systems are differentiated from their larger utility counterparts on the basis of mass flow: industrial turbines are classified as those with a mass flow greater than $10 \mathrm{~kg} / \mathrm{s}(22 \mathrm{lb} / \mathrm{s})$, but not to exceed $55 \mathrm{~kg} / \mathrm{s}(120 \mathrm{lb} / \mathrm{s})$. Though funded separately, the Ceramic Stationary Gas Turbine (CSGT) program, for which Solar is the sole contractor, is also considered a part of the overall ATS program.

\section{SOLAR'S ROLE IN ATS}

On September 14, 1995, Solar Turbines was awarded a six-year contract to develop two sizes of ATS products. Solar's efforts can be viewed as three distinct parts based upon a logical partitioning of the development tasks. Phase 3A covers the design of the ATS and the component level testing necessary to validate the higher risk elements of the design prior to proceeding to the next phase of the program. Phase $3 \mathrm{~B}$ addresses the integrated subsystem testing to further demonstrate suitability of the design(s) at the system level, as well as the assembly and test of the demonstrator packages themselves. Finally, Phase 4 will encompass the field installation and test of the ATS in existing production facilities as a demonstration of the commercial viability of the final design.

Solar's approach to product improvements and introduction has traditionally followed marketplace demand. The purchasers of Solar's products, over $80 \%$ of whom are repeat customers, claim that the commercial success and viability of next-generation products, such as ATS, in the industrial marketplace will depend upon several factors:

- High reliability and durability

- Customer perception of low risk

- Broad power range with excellent turndown

- World-class product support

- Low first cost 
- Low life-cycle cost

- Ability to permit the installation in the face of stringent regulatory environments.

\section{PRODUCT GOALS}

In developing the Mercury 50 gas turbine concept, Solar considered these marketplace requirements in conjunction with the DOE/industry ATS program objectives. The most significant demand peak was noted at approximately $5 \mathrm{MWe}$ in output, driven primarily by the industrial power generation and emerging distributed generation market segments for whom efficiency and first cost are key requirements. For applications such as this, a single-shaft configuration appeared to be the best approach.

In response, Solar developed the Mercury ${ }^{\top \mathrm{M}} 50$ gas turbine, which was announced to the public in 1998 at the ASME Turbomachinery Exhibition in Orlando, Florida. It is an optimized recuperated gas turbine, nominally sized at $4.2 \mathrm{MWe}$ on a $27^{\circ} \mathrm{C}\left(80^{\circ} \mathrm{F}\right)$ day $(4.9$ MWe at ISO conditions). This environmentally superior system incorporates a highly flexible combustion system that can be configured for either ultra lean-premixed or catalytic combustion, with an ultimate goal of 5 ppmv NOx on natural gas without the use of add-on, post-combustion pollution control devices. The Mercury ${ }^{\top \mathrm{M}} 50$ gas turbine is a single-shaft machine designed around an optimized recuperated cycle that is targeted to meet the rapidly expanding demand for highly efficient, environmentally superior turbinebased power systems in the industrial power generation markets. 


\section{MERCURY'M 50 GAS TURBINE DESIGN}

Increases in firing temperatures and compression ratios, combined with the use of advanced cooling, sealing and materials technologies have been the traditional approaches to improving turbine performance. While such technology improvements can offer significant benefits, industrial gas turbine users have traditionally avoided new technologies out of concern for the potential impacts on overall reliability. Instead, they prefer a sensible balance between the demonstrated benefits of key technologies and the high reliability requirements demanded by their processes.

This led Solar to evaluate the use of compound cycles based upon demonstrated technologies as the approach most likely to yield a step improvement in efficiency without unduly risking reliability in the process. Initially, a wide variety of candidate cycles was assembled for consideration. The benefits and drawbacks of each concept were qualitatively assessed against key customer buying criteria, including performance, cost, risk, growth capability, reliability and customer acceptance. From this process, two cycles were carried forward as potential solutions: intercooled and recuperated (ICR) and recuperated.

Recuperation of the classic Brayton cycle gas turbine is a well-known method of improving cycle efficiency that involves the addition of a heat exchanger to recover some portion of the exhaust heat that would otherwise be lost to the cycle. The differential between the exhaust gas temperature and the compressor discharge temperature determines the extent of the efficiency improvement that can be realized. Intercooling the Brayton cycle involves the addition of an interstage heat exchanger, to reject a portion of the heat generated during the compression process, which significantly reduces the work input required by the compressor. The combination of intercooling and recuperation into an ICR cycle produces an increase in both specific power and thermal efficiency. This enables the recovery of a greater portion of the thermal energy in the exhaust gas at the expense of an increase in the complexity of the machine. Figure 3-32 graphically contrasts the flow paths associated with simple cycle and recuperated cycles. 

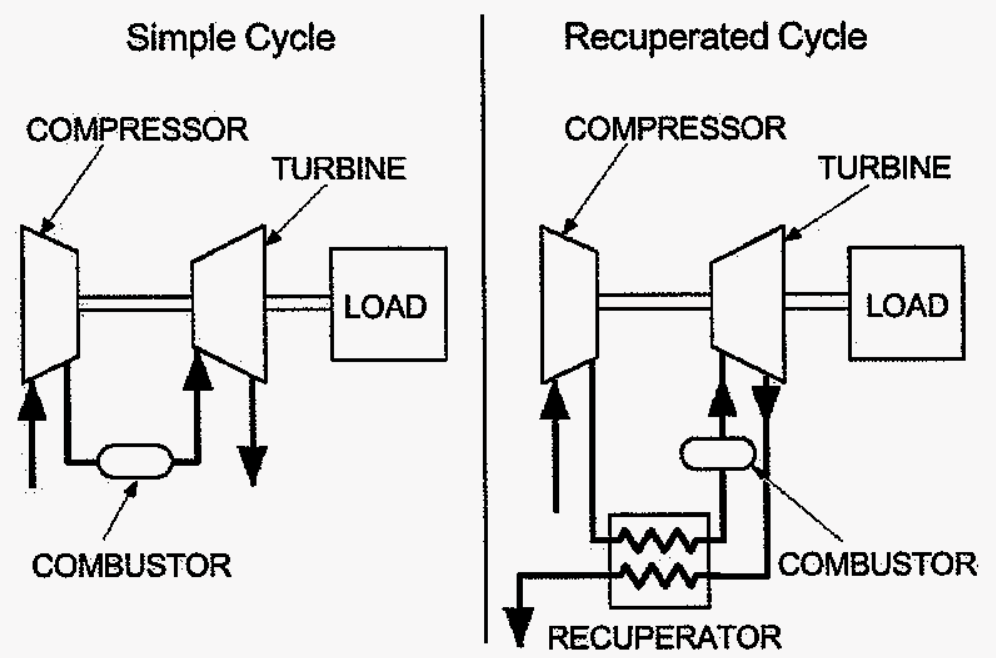

Figure 3-32 - Comparison of simple and recuperated cycles.

A more detailed process known as quality functional deployment (OFD) was then used as a formal means of evaluating the technical characteristics of both competing cycles versus the perceived customer requirements. In the final analysis, the recuperated cycle was selected as the most favorable due to the less complicated cycle and lower firing temperature, which improve system availability, emissions and the user's perception of risk. In the future, other efficiency-enhancing cycle modifications, such as intercooling, will become more attractive in the marketplace as the benefits, reliability and costs of the more complex systems are incrementally proven relative to the cost of fuel.

Solar's technical approach to ATS emphasizes the use of system-level design solutions that take advantage of a wide variety of demonstrated technological advances, each providing sufficient margin to assure the superior durability and availability required by industrial gas turbine users. Combinations of innovative primary and backup design solutions have been carefully blended to offer maximum cycle efficiency and emissions reductions with minimal risk, as adequate design margin is maintained within each selected technology.

Primary Surface Recuperator. Recuperated cycles have been applied to gas turbines in the past with varied degrees of success. In general, bulky tube-shell or plate-fin heat exchangers were added to existing turbines via somewhat elaborate and often cumbersome piping and support arrangements, with little or no attempt made to optimize the cycle. The result was a lukewarm performance improvement accompanied by poor 
thermal transient response, thermal cracking and other mechanical performance problems within the recuperator that often failed to meet customer expectations. Yet, when a prime mover, such as Solar's Mercury ${ }^{\mathrm{TM}} 50$ gas turbine, is designed to incorporate the recuperator from the start, significant gains can be realized without causing the mechanical performance issues that have occurred in the past.

At the heart of the Mercury ${ }^{\mathrm{TM}} 50$ gas turbine lies Solar's proven primary surface recuperator (PSR). As outlined in Figure 3-33, the construction is rugged and the modular nature of the design gives it superior flexibility to handle thermal stresses. Air cells are constructed from $0.1-\mathrm{mm}(0.004-\mathrm{in}$.) thick sheets of Type 347SS folded into a corrugated pattern. This folded shape maximizes the primary surface area that is in direct contact with exhaust gas on one side and compressor discharge air on the other. Pairs of these sheets are welded together around the perimeter to form air cells.

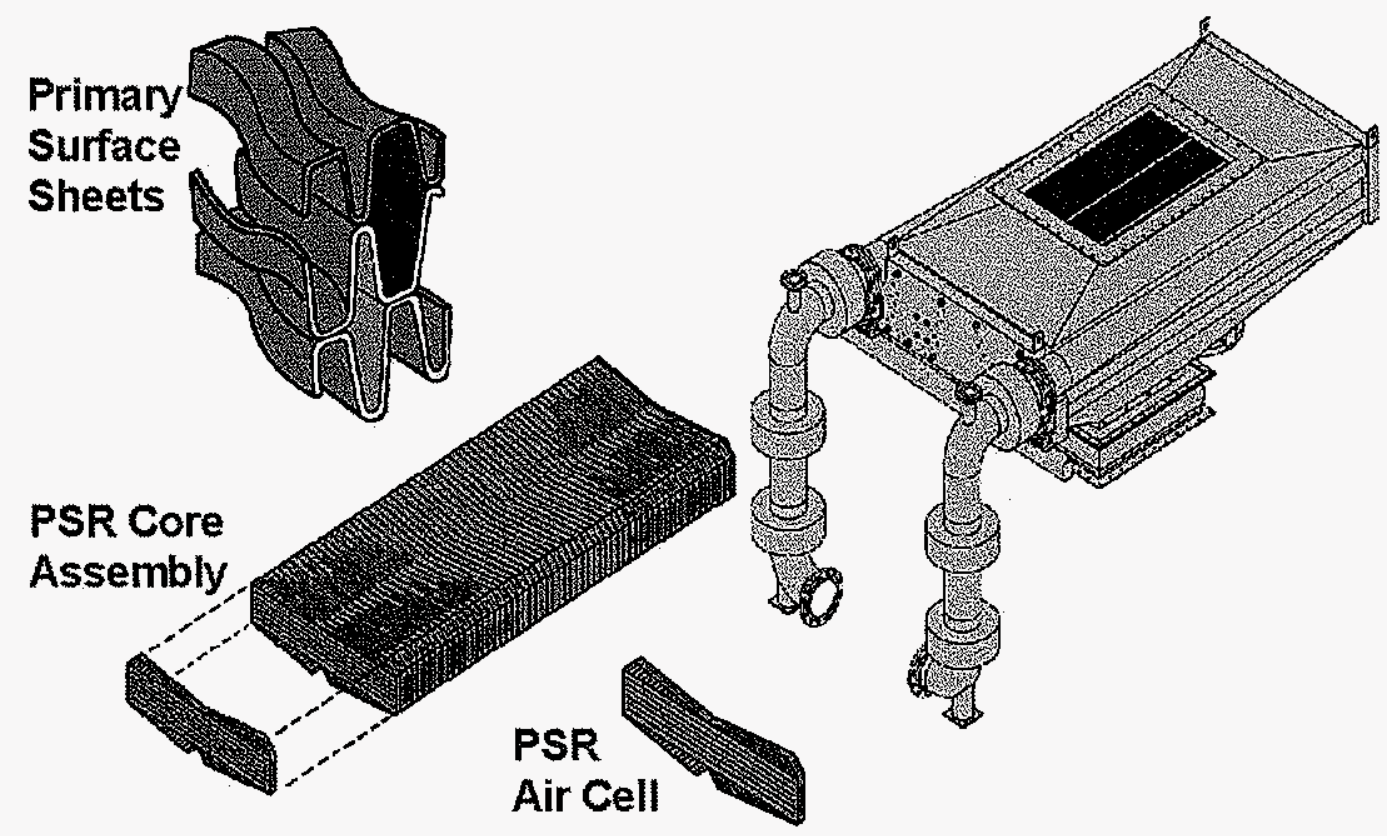

Figure 3-33 - Construction of the primary surface recuperator (PSR).

There are no internal welds or joints within the air cells, which are the basic building block of the PSR. Groups of these cells are sandwiched together via an arrangement of clamping bars and are welded to intake and discharge headers to form the recuperator assembly. Developed by engineers at Caterpillar Inc. in the early 1970 s for vehicular ap- 
plications, the PSR has undergone numerous refinements and has been successfully applied to a variety of gas turbines over the years. To date, Solar's PSRs have accumulated in excess of 2.3 million operating hours with few of the incipient problems typical of alternative recuperator technologies.

In contrast, the nature of the PSR presents several major advantages over plate-fin and tube-shell heat exchangers. The PSR is inherently resistant to low cycle fatigue failure. Clamping the cells rather than rigidly welding them to one another allows the assembly to flex freely to relieve stresses, rather than concentrating stresses at the weld locations. Similarly, high cycle fatigue has not been a problem for the PSR due to the clamped design: the stacking of cells presents multiple friction interfaces for energy absorption. This characteristic also provides excellent exhaust sound suppression, eliminating the need for an additional silencing device and its associated pressure drop.

As illustrated in Figure 3-34, PSRs are significantly smaller and lighter than competing technologies, have superior performance, improved reliability and can easily accommodate the thermal transients associated with start-ups, shutdowns and full-load transients during turbine operation. The PSR provides the high effectiveness (>90\%), moderate pressure drop and long life demanded by industrial turbine applications.

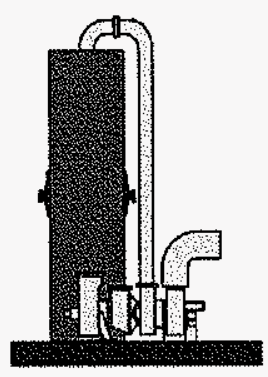

SHELL \& TUBE

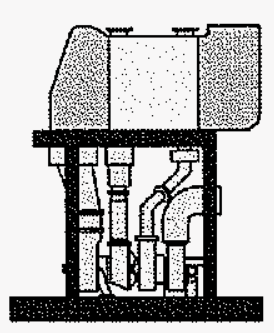

PLATE FIN

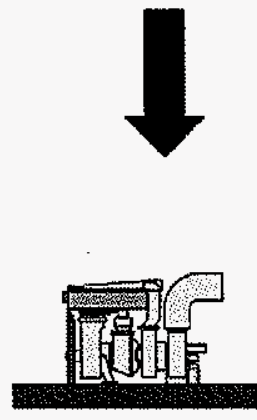

PRIMARY SURFACE

Figure 3-34 - Comparison of recuperator sizes.

Advanced Component Efficiency (ACE) Compressor. The Mercury ${ }^{\mathrm{TM}} 50$ gas turbine core design incorporates Solar's latest generation of compressors, the ACE compressor. Working in concert with Dr. John Adamczyk from NASA's Lewis Research Center in Dayton, Ohio, this line of highly efficient, rugged compressors has brought the latest aerodynamic design codes and modeling techniques to the design of industrial turbine 
compressors. These techniques were first applied during the redesign of the Mars $^{\mathrm{TM}}$ 100 compressor in 1993.

The ACE compressor design is characterized by the use of three-dimensional wide chord airfoils that are lightly loaded, resulting in a $40 \%$ reduction in the number of airfoils for a given pressure rise. These design characteristics result in a lower cost compressor that offers efficiencies equivalent to today's best aeroderivatives across a wider range of operating conditions. Validation of this design was completed in July 1997 at the U.S. Air Force's Compressor Research Facility at Wright-Patterson Air Force Base in Dayton, Ohio. During the course of this testing, compressor performance was fully mapped and compared versus the design goals, as well as that of Solar's current compressors. The results validated the ACE design codes and yielded an overall efficiency improvement that is more than two points better than the compressors in use on Solar's current line of gas turbines.

The single-shaft Mercury ${ }^{\top \mathrm{M}} 50$ gas turbine design uses a 10-stage ACE compressor (Figure 3-35) for a 9.1:1 pressure ratio. A variable inlet guide vane (IGV) is followed by two stages of variable guide vanes (VGV) that are interconnected and controlled as a unit for optimum compressor control across the operating load range.

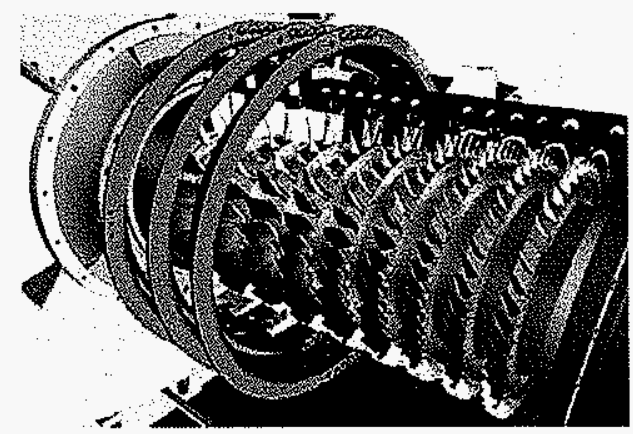

Figure 3-35 - Advanced component efficiency compressor.

Turbine Design. The design of the Mercury ${ }^{\top M} 50$ turbine section (Figure 3-36) incorporates several advanced features. A two-stage design was chosen for its inherent cost advantages and is characterized by a turbine rotor inlet temperature (TRIT) of $1163^{\circ} \mathrm{C}$ $\left(2125^{\circ} \mathrm{F}\right)$ and a highly loaded, fully cooled first-stage turbine. The second stage incorporates cooled vanes and uncooled, shrouded blades. Although a three-stage design 
would appear to offer superior efficiency, the additional air required to cool the added stage effectively negates any performance advantage.

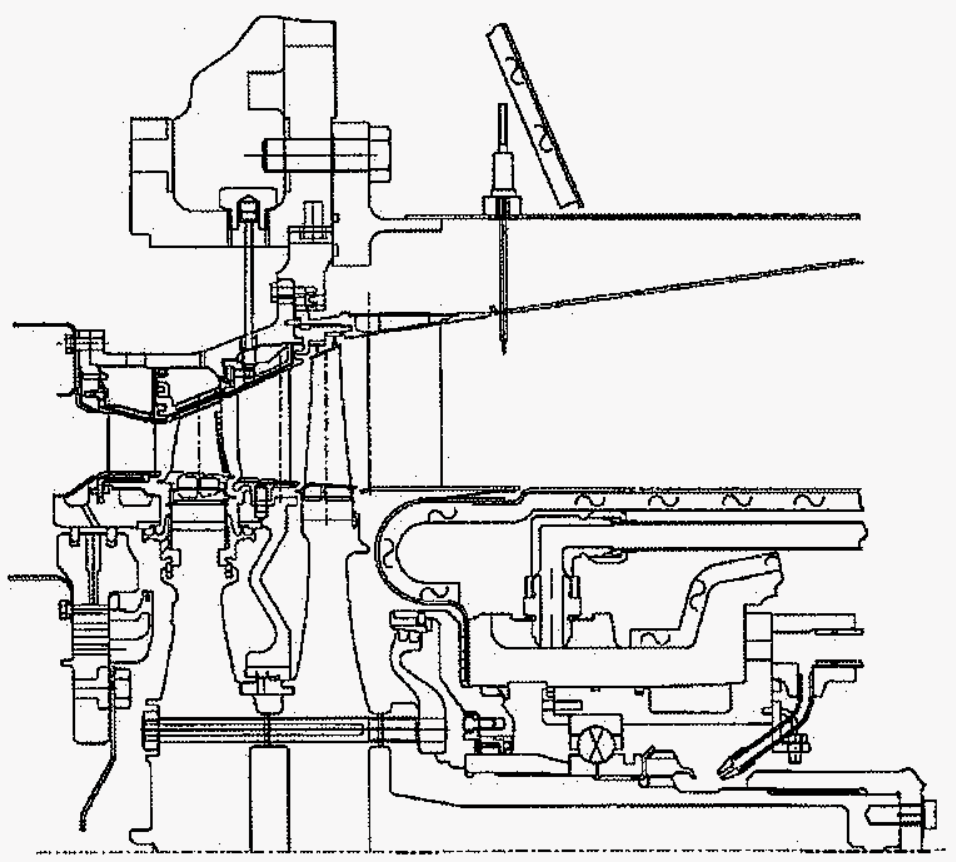

Figure 3-36 - Mercury ${ }^{\text {TM }} 50$ turbine section.

Turbine Cooling. Besides its impact on cycle efficiency, minimizing the use of cooling air has become increasingly important. For example, ultra lean-premixed combustion diverts a larger proportion of compressor discharge air to reduce primary zone temperatures, which makes the remaining cooling air a scarce commodity. Cooling the Mercury ${ }^{\mathrm{TM}} 50$ turbine is an even greater challenge due to the fact that $593^{\circ} \mathrm{C}\left(1100^{\circ} \mathrm{F}\right)$ air from the recuperator is the primary source of cooling. Meeting operating life requirements in this environment has driven advances in both turbine materials and cooling methods. Two advanced technologies have been applied: 1) the refined versions of the film and impingement cooling techniques used on Solar's Taurus ${ }^{\mathrm{TM}} 70$ gas turbine, and 2) a unique leading edge cooling scheme referred to as "vortex cooling."

Vortex cooling development has been under way for several years at Solar and involves the use of swirled cooling flow to the leading edge cooling circuit. The resulting vortices serve to direct the more dense, cooling air to the heat transfer surface and increase turbulence, both of which greatly improve leading edge cooling for a given amount of cool- 
ing air. Vortex cooling offers significant growth potential in terms of cooling effectiveness without incurring the performance penalties associated with showerhead cooling, which would otherwise be required in this high temperature application. This technique and the corresponding results were recently validated on a set of Mars first-stage turbine blades. This basic design, along with further refinements developed during the course of the Mars gas turbine test series, has been incorporated in the Mercury ${ }^{\mathrm{TM}} 50$ first-stage turbine blades.

Materials. The materials used in the manufacture of the turbine section are a key element in the durability of the Mercury ${ }^{\top M} 50$ gas turbine and represent a mix of current materials and next-generation alloys that are relatively new to industrial turbines (Figure 3-37).

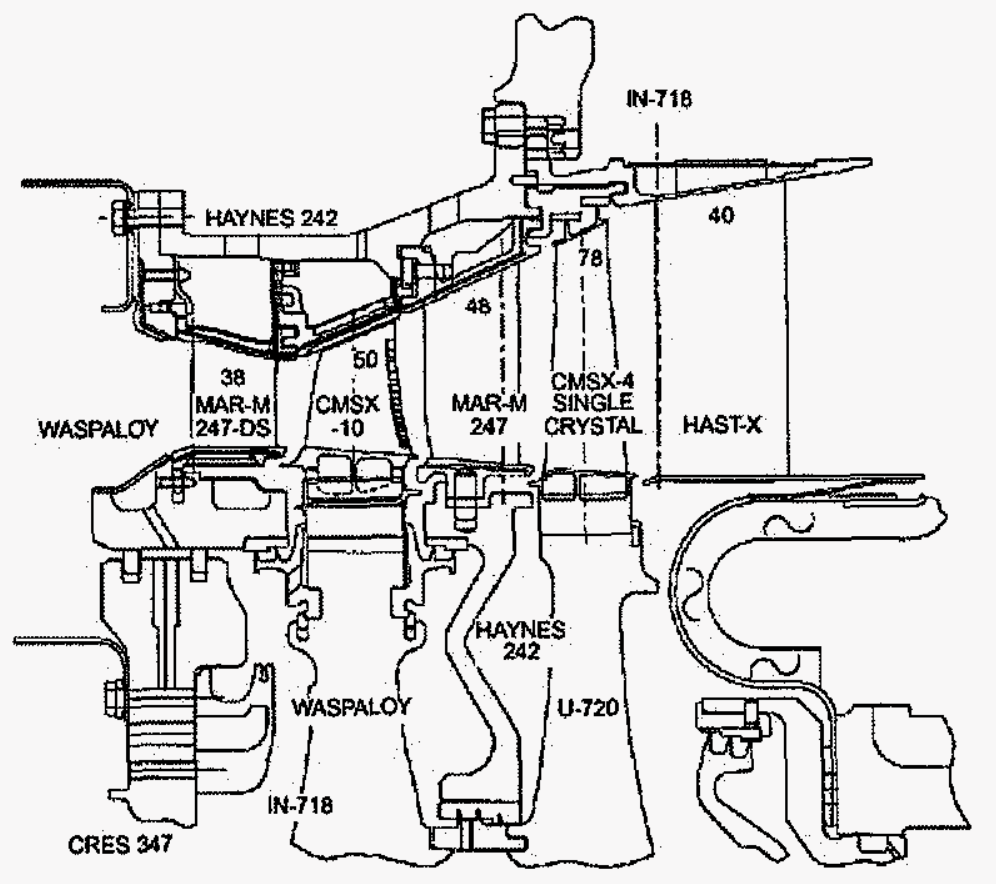

Figure 3-37 - Mercury ${ }^{\mathrm{TM}} 50$ turbine materials.

The film-cooled first-stage nozzles are constructed from directionally solidified MAR-M247, while the uncooled second-stage vanes are constructed from an equiaxed version of the same material. In the case of the unshrouded first-stage blades, a thirdgeneration single-crystal alloy, CMSX-10, has been selected for use. These blades will be mounted to a Waspaloy disk, using a version of Solar's traditional fir-tree design for 
blade retention, modified to allow for improved disk-post cooling. The second-stage blades are of a shrouded design and are manufactured from a second-generation singlecrystal alloy, CMSX-4.

The shrouded design was chosen due to its superior performance in terms of reduced tip leakage and the improved aerodynamics that derive from the increased aspect ratio of the blades. The uncooled second-stage blades have driven a unique set of requirements for the second-stage disk, for which traditional materials have insufficient mechanical properties. A powdered metal forging of Udimet 720 has been selected for use. The fine grain structure of the rim makes it suitable for the higher rim operating temperatures of the Mercury ${ }^{\mathrm{TM}} 50$ gas turbine while still maintaining sufficient low cycle fatigue strength at the hub.

Rotor Design. A three bearing, single-shaft rotor design has been selected for benefits in dynamic performance and stability during transient operating conditions, such as hot restarts and emergency shutdowns from full load. The bearing arrangement (Figure 3-38) incorporates viscous damped rolling element bearings, in lieu of hydrodynamic bearings, in order to reduce the sizes and, therefore, the cost of the oil sump, pumps, coolers and associated piping. The system employs two roller bearings in the compressor section and a hydraulic damping system designed by Solar for the Mercury ${ }^{\mathrm{TM}} 50$ gas turbine application. The damping system is fed from the bearing oil supply and mitigates dynamic transients during operation. The thrust bearing, a viscous damped ball bearing, is located downstream of the second-stage turbine rotor. The turbine rotors are overhung to minimize the distance between bearings and to allow the thrust bearing to be located in a cooler environment.

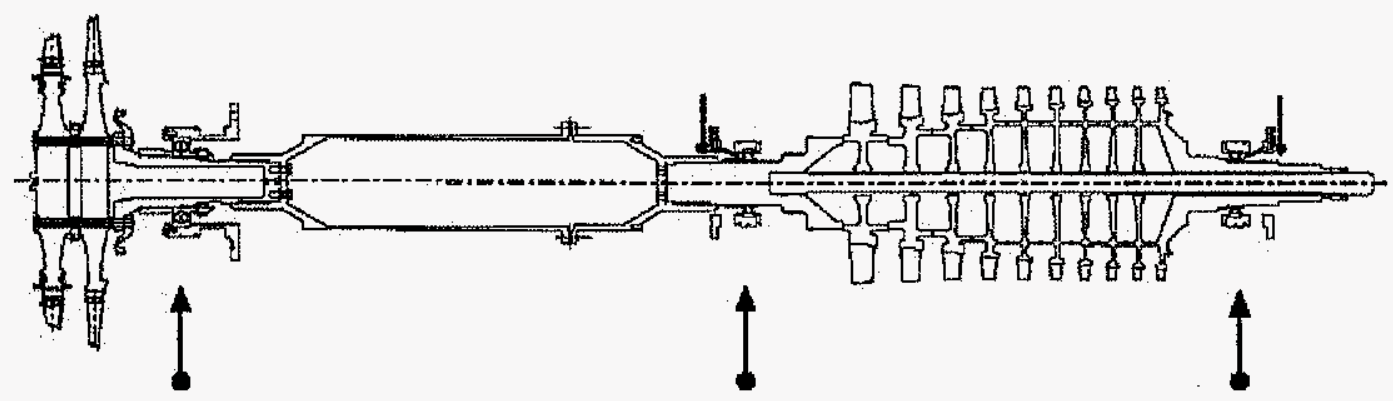

Figure 3-38 - Mercury ${ }^{\mathrm{TM}} 50$ rotor and bearing arrangement. 
Combustor. There are almost as many approaches to dry emissions control as there are manufacturers, though two technologies have attracted the bulk of the attention: lean-premixed combustion and catalytic, or flameless combustion. The mechanical configurations associated with each are distinctly different and lend themselves to different design approaches within the gas turbine. As will be described later, the design of the Mercury ${ }^{\mathrm{TM}} 50$ combustor will readily accommodate either technology so that it can be tailored to the needs of the particular installation.

Ultra Lean-Premixed Combustion. The ultra lean-premixed design (Figure 3-39 and Figure $3-40$ ) of the Mercury ${ }^{\mathrm{TM}} 50$ gas turbine is a continuation of Solar's successful SoLoNOX ${ }^{\mathrm{TM}}$ technology. The design incorporates eight ultra lean-premixed injectors, a backside cooled annular combustor liner and closed-loop $\mathrm{CO}$ feedback control to achieve single-digit NOx emissions across the operating range.

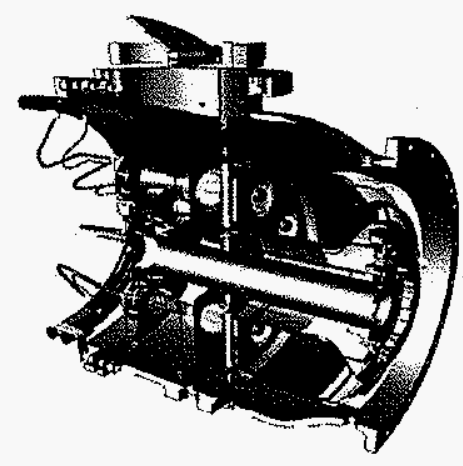

Figure 3-39 - Mercury ${ }^{\mathrm{TM}} 50$ combustor.

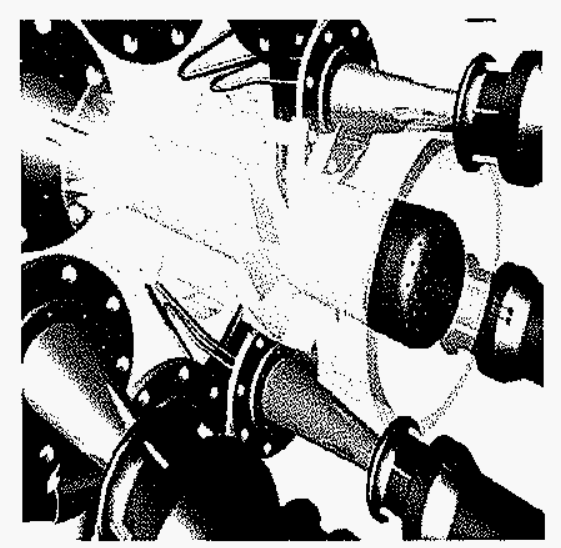

Figure 3-40 - Mercury 50 injectors. 
Refinement of the lean-premixed concept developed for the SoLoNOx product line to support single-digit NOx emissions requires the use of additional dilution air through the injector body to reduce primary zone temperatures to $1454^{\circ} \mathrm{C}\left(2650^{\circ} \mathrm{F}\right)$. The use of variable geometry effectively modulates airflow through the injectors as a function of load to maintain consistent primary zone temperatures; however, the pressure drop across the combustor increases significantly at lower loads as excess dilution air is bypassed around the injector. Bleeding air from the combustor case at lower power settings can mitigate this, but at the expense of part-load efficiency. The compensating nature of the variable geometry design is such that the pressure drop across the combustor remains relatively constant, allowing lean operation across a wide load range without the need for compressor bleed at intermediate loads. The injectors are designed to operate in concert with the air diverter valve to bypass excess dilution air to maintain a reasonably constant fuel/air ratio and stable primary zone temperatures necessary for sustained low emissions operation.

Conservation of cooling air and the effects of combustor liner cooling on the formation of $\mathrm{CO}$ during the combustion process have brought about a change in the way the Mercury $^{\mathrm{TM}} 50$ combustor liner is cooled. As primary zone temperatures are reduced to support single-digit NOx combustion, $\mathrm{CO}$ levels tend to rise, particularly in the vicinity of the relatively cool liner walls, where the $\mathrm{CO}$-to- $\mathrm{CO}_{2}$ reaction is quenched. Minimizing $\mathrm{CO}$ and NOx drives a balance between higher temperatures for reduced $\mathrm{CO}$ and lower temperatures for reduced NOx. The alternative liner cooling scheme, referred to as augmented backside cooling $(A B C)$, maintains higher wall temperatures as compared to louver or effusion cooling techniques to further retard the formation of $\mathrm{CO}$ during the combustion process. This, in turn, allows the reduced primary zone temperatures necessary for single-digit $\mathrm{NO} \times$ without sacrificing an increase in $\mathrm{CO}$ emissions.

The combustor liner is protected by a ceramic thermal barrier coating (TBC) that is plasma sprayed on the metallic substrate. The addition of dimples and/or trip strips to the back side of the liner serves to break up the boundary layer and promote improved heat transfer. Liners manufactured from continuous fiber-reinforced ceramic composites (CFCC), a design being developed for the CSGT program, are also being considered for use in the Mercury ${ }^{\mathrm{TM}} 50$ gas turbine application as this technology matures. Improvements in mixing capability and minimization of combustor oscillations are key de- 
sign advances that have been incorporated into the Mercury ${ }^{T M} 50$ dual fuel injectors. The use of airfoil main air swirlers with integral gas injection at the upstream edges improves premixing to promote lean combustion while preventing flashback. In the liquid mode, the use of air atomization during lightoff and air cooling of the tip have been added as refinements to the basic design. The incorporation of closed-loop emissions controls will enable the Mercury ${ }^{\top M} 50$ gas turbine to maintain single-digit emissions across a wide range of loads and operating conditions. A CO sensor has been added to the turbine exhaust and is used to drive a proportional control loop that continually adjusts compressor inlet guide vanes, the air diverter valve and the fuel control to accurately control the level of $\mathrm{CO}$ and, hence, NOx formation during operation.

Catalytic Combustion System. The design of the catalytic combustion system follows more than four years of development work during which Solar refined and rig tested the basic design of the catalyst beds to prove their suitability for use in a gas turbine application. In a test rig, air and fuel are thoroughly mixed and allowed to partially react in the catalyst bed, where temperatures are kept sufficiently low to avoid damage to the substrate and supporting structure. Burnout is completed downstream of the catalyst bed, where temperatures remain sufficiently low to avoid the formation of NOX.

Initiation of the catalytic reaction normally requires the use of a preburner, which is essentially a small version of a SoLoNOx injector upstream of the catalyst bed. The preburner is used to raise the temperature of the fuel/air mixture to 510 to $538^{\circ} \mathrm{C} 1950$ to $1000^{\circ} \mathrm{F}$ ), in order to initiate the catalytic reduction of the fuel and air, and is the major source of what little NOx is produced by catalytic combustion systems. One of the many advantages offered by the recuperated cycle of the Mercury ${ }^{\mathrm{TM}} 50$ gas turbine is that it has eliminated the need for preburners and their associated NOx emissions. The combination of variable compressor and combustor geometry act together to allow control of mass flow through the machine as a function of load. Recovery of exhaust heat via the recuperator then allows combustor inlet air to be maintained at approximately $593^{\circ} \mathrm{C}\left(1100^{\circ} \mathrm{F}\right)$ at virtually all operating conditions.

The catalytic combustion system of the Mercury ${ }^{\top \mathrm{M}} 50$ gas turbine uses five catalyst cans, approximately $228.6 \mathrm{~mm}$ ( $9 \mathrm{in}$.) in diameter, and the same compensating geometry as the ultra lean-premixed system to maintain a consistent fuel/air ratio across the 50-to$100 \%$ operating range. A cooled can-to-annular transition piece is used to channel the combustor discharge to the first-stage turbine nozzles. Provisions have been made to 
accommodate rapid changeout of the catalyst beds as required with a minimum of downtime.

\section{PACKAGE DESIGN}

The traditional method of improving gas turbine performance has generally been limited to design changes within the gas turbine itself. These typically have been incremental changes to existing technologies that allow marginal improvements to firing temperatures, pressure ratios or cooling efficiencies. Unfortunately, this approach has failed to capitalize on improvements that can be realized in other areas of the gas turbine system. Specifically, the layout of the turbine in concert with the package has a significant impact on the cost, efficiency, reliability and maintainability of the gas turbine system.

In the case of a typical package, ancillary systems consume nearly $8 \%$ of the useful power of the machine and provide an excellent opportunity for improvement (Figure 3-41). As a consequence, Solar's approach to the design of its ATS engine has been heavily focused at the system level. Examples of this have been the use of variable frequency ac drive motors for lube oil pumps and cooling fans, where the power output can be tailored to meet the actual load requirements. Extensive use of advanced analytical design tools, such as computational fluid dynamics (CFD) combined with advanced aero codes and the use of vortex generators in the exhaust casing to improve pressure recovery, have contributed toward significant reductions in exhaust and inlet losses.

Advanced design and modeling techniques have also been applied to the gearbox design. The use of double helical gearing in the epicyclic gearbox, an approach typically reserved for much larger applications, has eliminated the need for thrust bearings and improved component efficiency in the process. Finally, in concert with generator suppliers, Solar is applying technologies typically reserved for use in much larger generators to achieve similar improvements in component efficiencies. The use of profiled conductors for the stator windings and thin-layer laminates made from advanced materials are two key contributors to this achievement. 


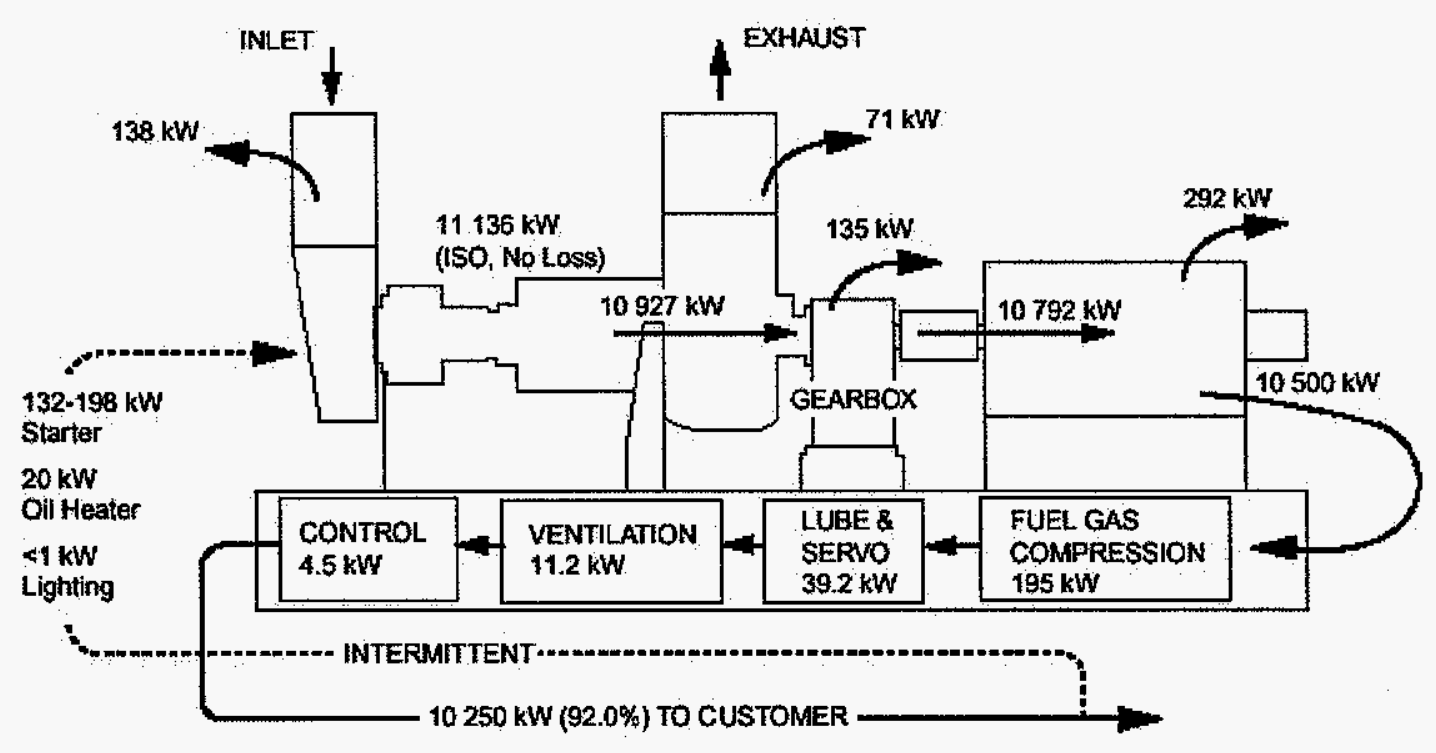

Figure 3-41 - Parasitic losses in a gas turbine package.

General Layout. One of the most significant Mercury ${ }^{\Upsilon M} 50$ gas turbine innovations is the layout of the core prime mover, around which the package has been synergistically designed. The results offer significant advantages in terms of cost, performance and maintainability.

Combustor Flexibility. The need to accommodate multiple combustion systems has been a major factor in the design of the Mercury ${ }^{\mathrm{TM}} 50$ gas turbine. Locating the combustion system between the turbine and compressor, as dictated by past convention, limits the ability to make changes without significantly impacting other subsystems. The centerline design fixes the length of the combustor, and the compressor and turbine cases define the mating interfaces. This has led to the adoption of a unique layout that will accommodate either the ultra lean-premixed or catalytic combustion systems and represents a new innovation in the design of industrial gas turbines. The combustor case and diverter valve assembly are common to both systems, while the end cover, liners, injectors and manifolding are unique to each combustion system.

Simplified Flow Path. The complex flow path of the recuperated cycle also provided design challenges that were effectively addressed in the layout. The recuperator is supplied with air from the compressor discharge plenum on one end, while heated air is collected at the other end and supplied to the combustor. Turbine exhaust is collected at 
the bottom center of the recuperator and discharged from the top. On a conventional turbine, this flow path requires a somewhat complex series of piping, elbows, flanges, bellows and pipe hangers. By altering the arrangement of the components, as shown in Figure 3-42, a graceful flow path can be accommodated that naturally follows the flow of the recuperator. Compressor discharge is at the end of the machine in the same plane as the inlet header to the recuperator. The inlet to the combustor is located at the end of the machine in the same plane as the recuperator discharge header. Finally, the turbine exhausts at the center of the gas turbine and discharges up through the recuperator.

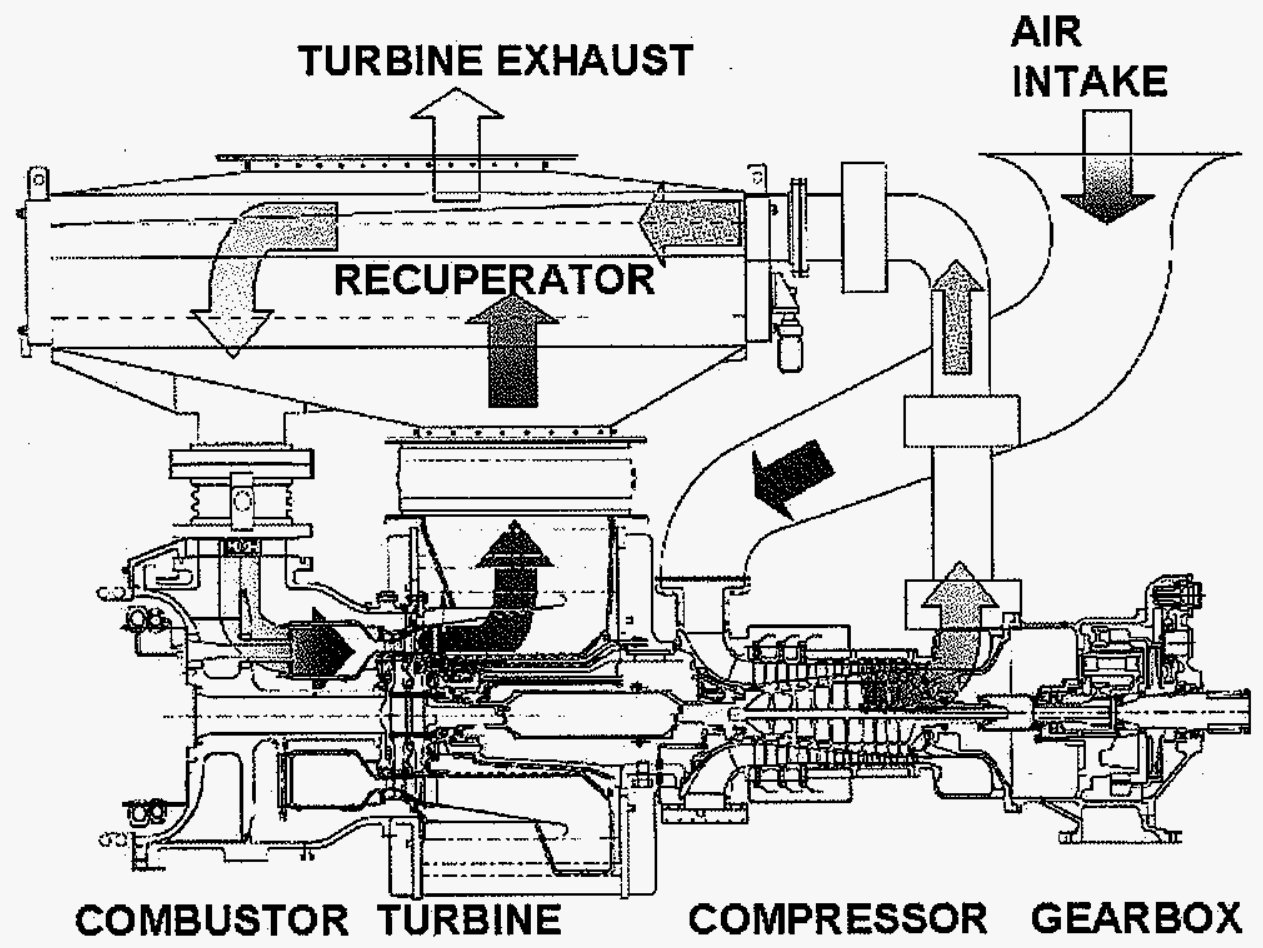

Figure 3-42 - Mercury ${ }^{\mathrm{TM}} 50$ core gas turbine and recuperator flow path.

A uniquely designed component referred to as the center frame is used to interconnect the turbine and compressor sections in lieu of the hot strut designs typically used by gas turbines. Since the load carrying members of the center frame are located in a cool environment external to the turbine flow path, axial movement of the turbine case due to thermal growth is minimized, permitting tight tip clearances. 
Electric Power Generator. Net shaft power is delivered at the turbine cold-end through a helical-gear gearbox to an air-cooled $A C$ generator. For $60 \mathrm{~Hz}$ output, which was the basis for this project, the 14,200 rpm turbine shaft speed is reduced by the gearing to $1,800 \mathrm{rpm}$, the generator design speed. Mercury $50 \mathrm{AC}$ generators are available that can deliver design output voltages in the $3,300 \mathrm{~V}-13,800 \mathrm{~V}$ range, the high value being assumed in this study. The study also assumed that Mercury 50 power output would be delivered directly to the utility AC grid; no consideration was given to an overall power management system that would integrate and deliver to the grid the combined power outputs of the PSOFC generator modules and the Mercury 50 gas turbine.

Modular Assembly and Maintenance. Another factor in the design of the package was the desire for modularity in which each of the major subsystems, including combustor, turbine, compressor, recuperator, gearbox and generator can be changed independently in the field in a single work shift. The ability to replace modules, instead of an entire turbine, can also limit the amount of onsite troubleshooting required because the modules can be quickly replaced and repaired off line. The modular nature of the design, as depicted in Figure 3-43, is central to the Mercury ${ }^{\top M} 50$ gas turbine $98.5 \%$ availability goal targeted at the beginning of the program.

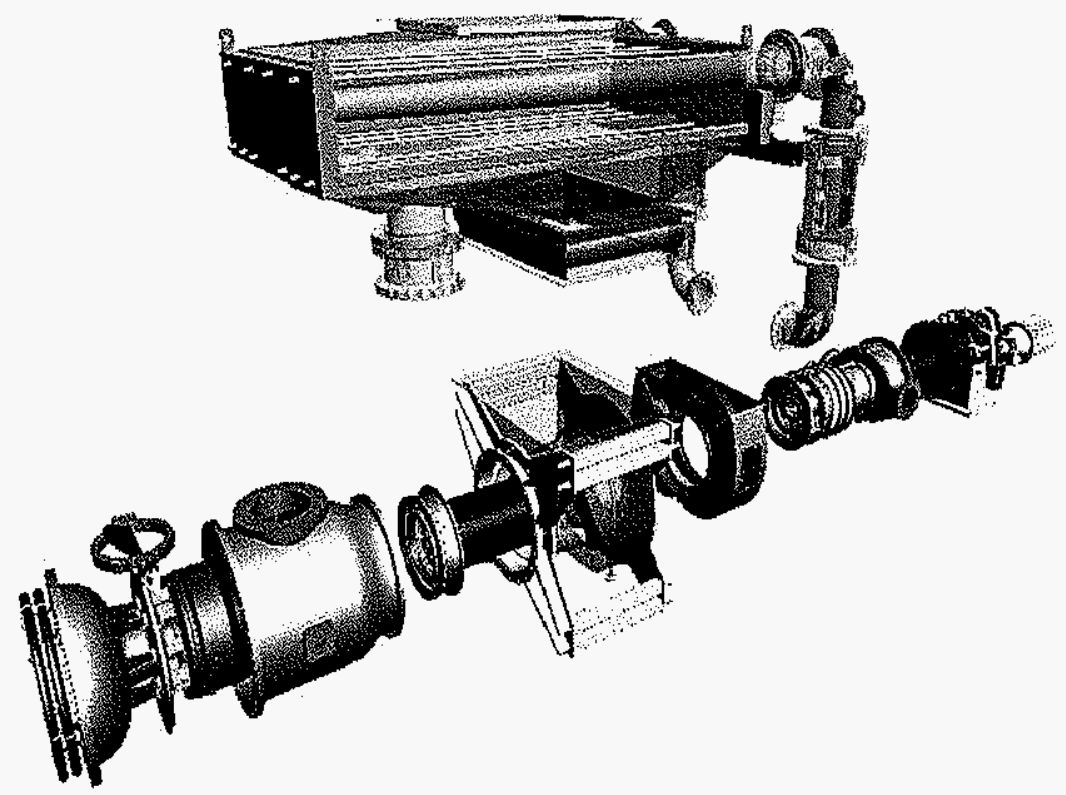

Figure 3-43 - Modular arrangement of Mercury ${ }^{\mathrm{TM}} 50$ advanced turbine system. 
Changeout of modules and major components is accommodated as follows:

- Liner/njector Changeout. Injectors and ignitors can be unbolted and withdrawn from the end cover for individual servicing as required. In addition, the combustor end cover can be unbolted, removed and withdrawn from the case to provide direct access to the combustor liners, injectors, ignitors and manifolding. These components can be serviced individually or replaced as an entire assembly as required.

- First-Stage Turbine Nozzle. The entire combustor assembly can be unbolted and withdrawn to provide clear access to the first stage turbine nozzles for replacement without disturbing the remainder of the turbine.

- Turbine Assembly and Thrust Bearing. The turbine shaft coupling is unbolted from the compressor via an access port in the center frame. Then, following removal of the combustor assembly as previously described, the turbine assembly is unbolted from the center frame and withdrawn and replaced as a unit.

- Compressor Assembly. The turbine shaft coupling is disconnected as previously described and the compressor is unbolted from the center frame. The compressor can then be withdrawn and replaced as a unit.

- Gearbox and Generator. Unbolting the couplings for these units allows them to be individually removed from the package and replaced without disturbing the other components.

Multiple Rating Capability. Further operating flexibility has been added through the use of multiple ratings that allow power output and time between overhaul (TBO) to be traded off and tailored to the specific application. Turbine rotor inlet temperature (TRIT) is inversely varied as a function of annual operating hours, thus allowing one size of turbine to serve in a variety of applications for continuous, intermediate and peaking duties. This multiple rating approach also allows the customer to maintain a reasonably consistent TBO schedule on a calendar basis from one application to another.

\section{SUMMARY}

The demand for low cost, reliable power has increased dramatically in recent years. With this increased demand, the industry has seen a push toward power generation equipment in smaller sizes in a wide variety of applications. This size range has long been dominated by reciprocating engines, where their low first cost and high efficiency, compared to small industrial turbines, have given them an advantage in applications. where footprint, emissions and maintenance are not key issues. Emerging societal trends, however, are pushing toward progressively lower emissions, fuel flexibility and unobtrusive installations in non-industrial locations. 
Large domestic reserves of clean-burning natural gas have made this the fuel of choice in many applications. Also, the need to cleanly burn a wide variety of "fuels of opportunity," such as digester gas, landfill gases, and refinery by-products, has placed everincreasing importance on the design of combustion systems. Together, these marketplace trends are tipping the scales in favor of industrial turbines for many applications. This has led Solar to design the Mercury ${ }^{\top \mathrm{M}} 50$ gas turbine from the centerline out to synergistically incorporate efficiency, environmental performance, fuel flexibility, cost of power, reliability and maintainability.

Matching a power generation product that effectively meets the varied goals of a diverse customer base with the emergence of markets such as distributed generation has created excellent growth opportunities for manufacturers of industrial power generation equipment.

The Mercury ${ }^{\top M} 50$ gas turbine has been designed to offer superior performance and operating flexibility at a price that is competitive with alternative power generating technologies. Scaled to different sizes as is currently envisioned, the Mercury ${ }^{\text {TM }} 50$ gas turbine family is capable of satisfying the needs of a wide array of users in a number of different applications. It represents a balanced approach to the trade-off between the benefits of new technology, low cost and high reliability that are targeted directly at the needs of the industrial power generation market.

\subsubsection{SOFC Power Conditioning System}

The power conditioning system design concept and the material presented in this report section were developed by Mesta Electronics, Inc., North Huntingdon, PA.

\subsubsection{Introduction}

This section describes the design approach, design justification and preliminary packaging for a DC/AC Power Conditioning System (PCS) to be used in conjunction with the PSOFC generator modules. The PCS must be capable of converting the available DC power from the modules to $A C$ power, which must then be phase locked and voltage equalized to the power grid. 
To accommodate varied distribution voltages and power requirements, the approach consists of a $(p X s)$ modularized-matrix of inverters. The power conversion equipment will consist of several smaller, high frequency, pulse width modulated (PWM) controlled inverters where the $p$ elements represent the parallel connections and the s elements represent the series connections. The number of parallel elements is dependent upon the power requirements of the system and the current limitations of the switching devices. The number of series elements is dependent upon the open circuit voltage rating of the PSOFC and the collector-emitter direct voltage limitation of the switching device.

The modular-matrix power converter design will be complimented by a highly sophisticated microprocessor based control center design. Utilizing the latest state of the art, high-speed microprocessor with DSP (digital signal processor) complement, the control will integrate the proper $A / D$ interfaces and multiplex the inverter controls. The control center will be programmed to receive information about voltage, current and other pertinent data from each module in the matrix, make the necessary calculations and/or decisions and output the appropriate command to each inverter in the matrix.

The control center will be responsible for the active equalization of all inverter voltages and currents. To ensure proper sharing based on this information, the control will synchronize and phase lock the output to the distribution line frequency and, through a PWM gating waveform, produce a high quality sinusoidal voltage output.

\subsubsection{Design Concept}

General. As illustrated in Figure 3-44, the power conditioning system servicing a single PSOFC generator module consists of several parallel columns of full bridge inverters. Each column, termed herein a Super Module, has one or more Basic Inverter Modules in series, and each inverter drives the primary winding of a transformer with a high frequency PWM waveform. The corresponding secondary of each winding is connected in series and/or parallel to an adjoining module to obtain the desired power level and voltage output. Each inverter/ transformer circuit is a separate DC-to-AC power conditioner. The actual number of $\mathrm{DC}$-to-AC power conditioners will be determined as the voltage and power requirements dictate. 


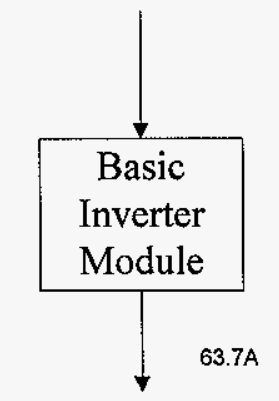

$$
\begin{aligned}
& \mathrm{VDC}=1400 \mathrm{~V} / 3=467 \mathrm{~V} \\
& \text { Pinverter }=128 \mathrm{~kW} \\
& \text { Vrms (primary) }=318 \mathrm{~V} \\
& \text { Iprimary }=232 \mathrm{~A} \\
& \text { Vsec }=1992 \mathrm{~V} / 3=664 \mathrm{~V} \\
& \text { Isecondary }=63.7 \mathrm{~A}
\end{aligned}
$$
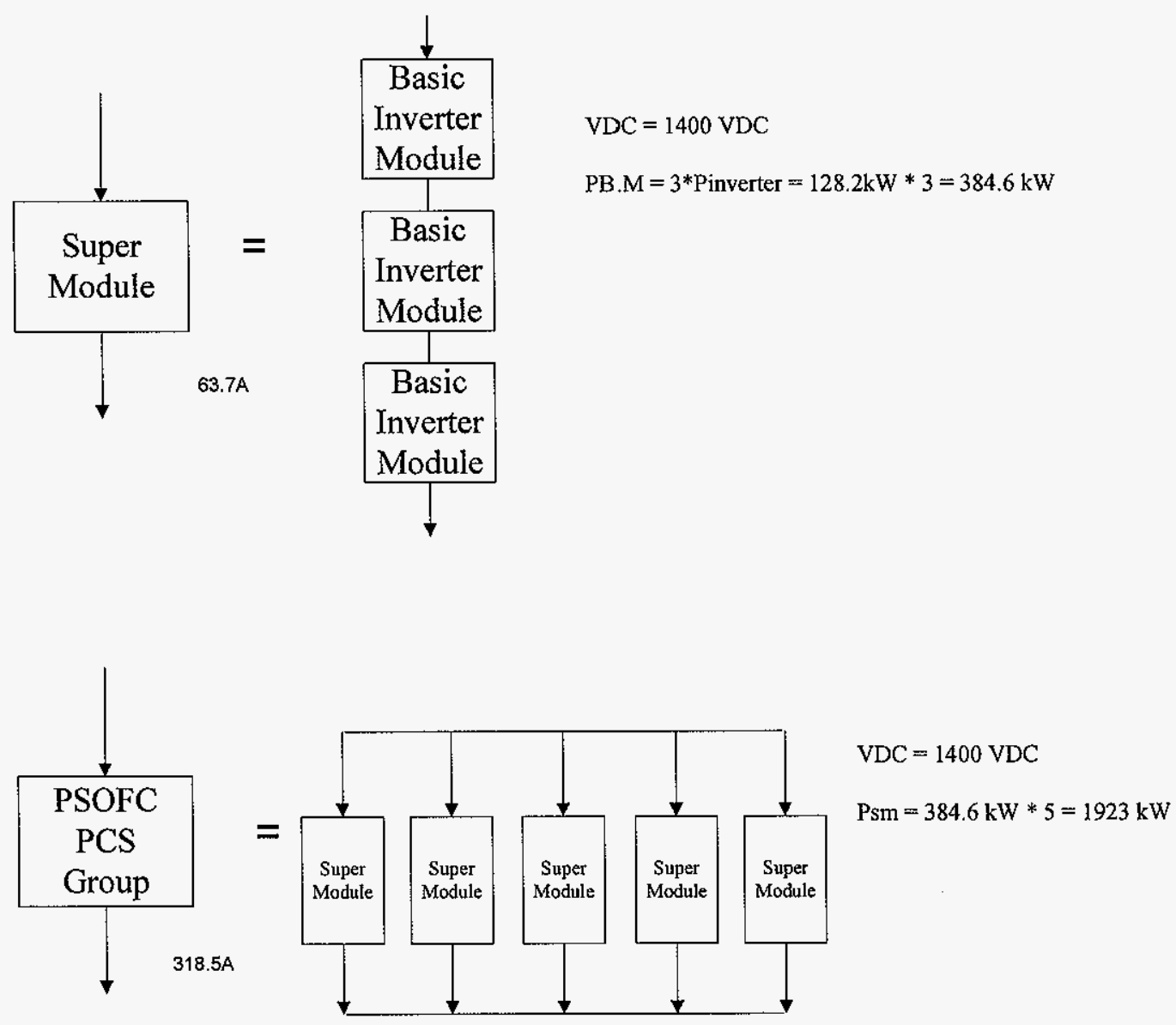

Figure 3-44 - PCS design concept. 
This matrix type arrangement of many DC-to-AC power conditioners enables very large power conditioning systems to be constructed from relatively simple smaller conditioners. The modular approach and microprocessor control will permit the construction of a power conditioning and control system for just about any selected input or output voltage. Modular design also provides an inherent system redundancy resulting in increased reliability. Losing a single DC-to-AC power conditioning unit will not result in a complete shutdown of the system but instead will result in slightly reduced performance. Furthermore, using relatively small DC-to-AC power conditioners will permit the use of higher switching frequencies, thus resulting in smaller sized magnetics and filtering networks, which in turn will result in lower system size, weight and cost.

Design Considerations. The two main considerations in determining the proper design approach are the PSOFC ratings and the commercial availability of the switching devices used in the inverter sections. During the design and device selection process, the first order concerns are the open circuit voltage rating and the available full load current. While commercially available isolated gate bi-polar transistors (IGBTs) have voltage ratings up to $3300 \mathrm{~V}$, the devices chosen for this analysis are restricted to $1200 \mathrm{~V}$. Presently, IGBTs rated for higher than 1200 Volts exhibit much greater switching losses which inhibits their use at higher switching frequencies and their thermal management becomes more difficult.

The open circuit voltage rating is determined from the V-I characteristic curve for the PSOFC. The end points of the curve define the maximum voltage rating and the maximum DC current available. The maximum RMS ripple current generated by the PCS is to be $2 \%$ of the DC current setpoint, for setpoints 370 ADC and above. From the curve, a single PSOFC generator module has the following ratings.

\section{PSOFC Module Terminal Ratings}

Output Power
Open Circuit Voltage
Nominal Operating Voltage
Full Load Current
Total Number of PSOFC Modules
Module Ripple Current

Siemens Westinghouse
$2100 \mathrm{~kW}$ 2000 VDC $( \pm 1000$ VDC) 1400 VDC Terminal -terminal 1480 ADC 4 (per 10 MWe-class power system) 8 (per $20 \mathrm{MWe}$-class power system) $\leq 0.5 \%$ full-scale for currents $>25 \%$ of module rating 
Lower power PSOFC designs are also considered which have a slightly lower open circuit voltage of 800 VDC. This lower open circuit voltage is used to define the optimum choice of a single inverter. To accommodate the 2000 VDC O.C. voltage of the $2100 \mathrm{~kW}$ PSOFC Module, three inverters would be arranged in a series string. This would give the inverter a series string with $3600 \mathrm{~V}$ withstand capability. Since all the external circuit parameters are not yet defined, this voltage rating would give the inverter string a comfortable safety margin. Table 3.4 summarizes the design approach.

Table 3.4 - Super Module Development

\begin{tabular}{|r|c|c|c|l|l|}
\hline \multicolumn{1}{|c|}{ Definition } & $\begin{array}{c}\text { Open Circuit } \\
\text { Voltage }\end{array}$ & $\begin{array}{c}\text { \# Inverters } \\
\text { in Series }\end{array}$ & $\begin{array}{c}\text { Individual } \\
\text { Inverter kW }\end{array}$ & $\begin{array}{l}\text { Total Available } \\
\mathrm{kW}\end{array}$ & Devices \\
\hline Inverter & $800 \mathrm{VDC}$ & 1 & $128.2 \mathrm{~kW}$ & $128.2 \mathrm{~kW}$ & $400 \mathrm{~A} / 1200 \mathrm{~V}$ \\
\hline Super Module & $2000 \mathrm{VDC}$ & 3 & $128.2 \mathrm{~kW}$ & $384.6 \mathrm{~kW}$ & $400 \mathrm{~A} / 1200 \mathrm{~V}$ \\
\hline
\end{tabular}

Basic Inverter Module Construction. The most basic component of the power conversion system is the Basic Inverter Module. The Module, configured as indicated in Figure $3-45$, consists of the DC link section, full wave power inverters comprised of three inverter poles, the output transformers and control section. The rating for the Basic Module will be $128.2 \mathrm{~kW}$ at $480 \mathrm{VAC}$ or $600 \mathrm{VAC}$ at the output terminals through the step-up transformer.

The DC link section will be the interface section between the energy converter and the PSOFC source. It will consist of the input DC breaker, branch circuit dc fuses, precharge network and ancillary control circuitry, and it will be the point of coupling to the PSOFC module.

The Basic Inverter Module will be configured as a full wave bridge, which will convert the DC bus voltage to a PWM controlled, $3 \varnothing$, output voltage. The PSOFC will be buffered from the DC bus by electrolytic capacitors, which will provide transient load ridethrough capability to the inverter. 


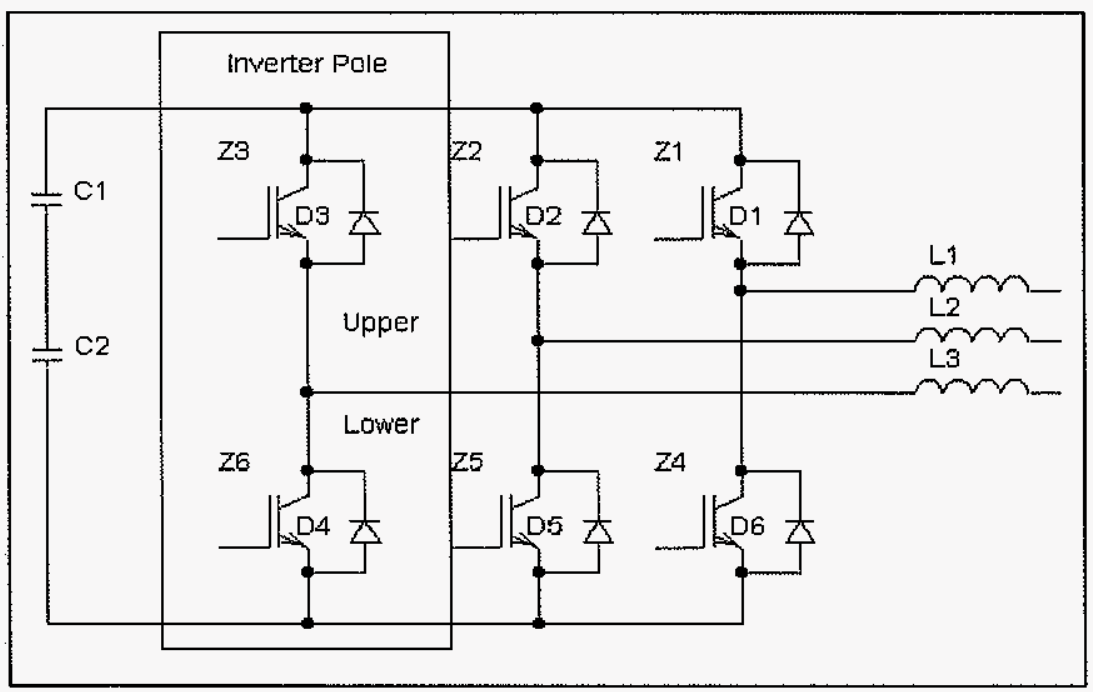

Figure 3-45 - Basic inverter module.

The PCS will be designed utilizing the Basic Inverter Module as a fundamental building block that can be configured to meet any voltage and power requirements. When three Basic Inverter Modules are connected in a series bridge arrangement, the higher input voltage requirements are satisfied. This grouping is referred to as a Super Module, Figure 3-46.

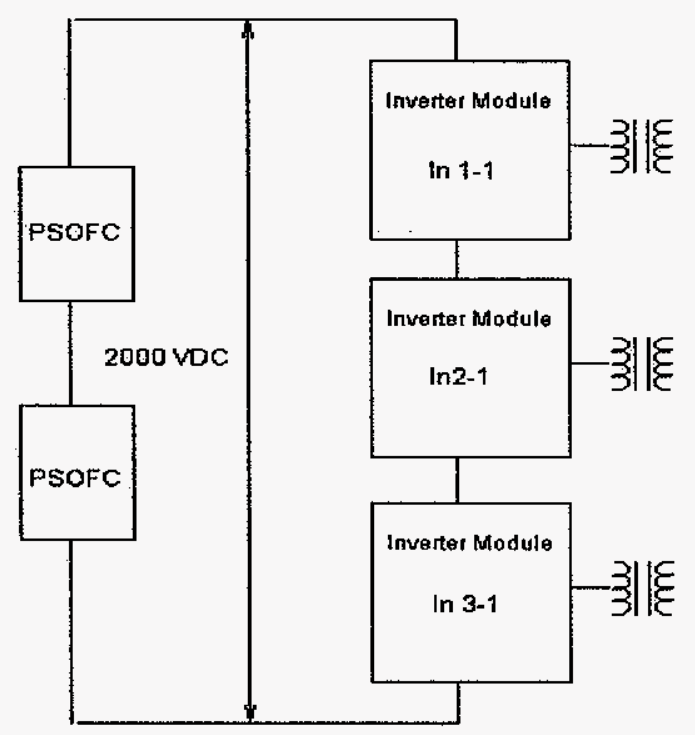

Figure 3-46 - Super module. 
The Super Module is connected to a PSOFC module with an open circuit voltage rating of 2000 VDC at a maximum current of 1480 ADC. Each inverter in the Basic Inverter Module drives the primary winding of a step up, isolation transformer by way of a PWM waveform. The corresponding secondary of each winding is cascaded in series or parallel to obtain the desired output voltage. Each inverter in the Super Module is a current source/voltage source inverter ensuring proper load sharing between inverter sections in the total matrix. In turn, the Super Modules are connected in series/ parallel cascades to match the load voltage and power requirements as shown in Figure 3-47.

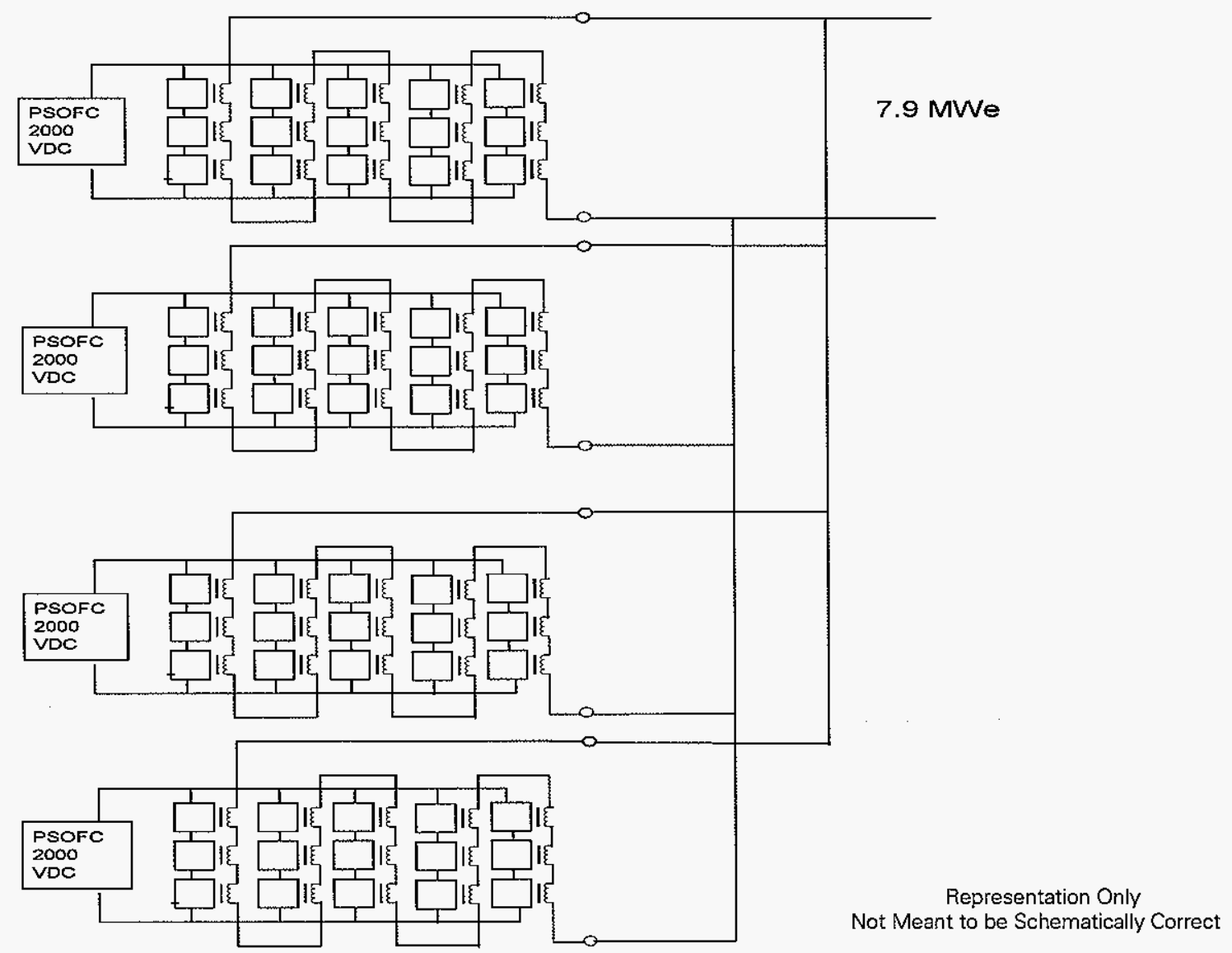

Single Phase One Line Diagram

Figure 3-47 - One-line diagram for power conditioning system associated with four PSOFC modules. 
Power Conditioning System for 7.9 MW AC. As shown in Figure 3-47, to facilitate a medium or high-voltage line voltage, multiple Super Modules are cascaded by connecting the secondary windings of the inverter transformers in a series connection. The three-phase connection is arranged such that the delivered line to line voltage can be as high as $13.8 \mathrm{kV}$. The deliverable power to the grid from four PSOFC modules is characterized as follows:

$\begin{array}{ll}\text { Output Power } & 7.9 \mathrm{MW} \\ \text { Line to Line Voltage }\left(V_{\mathrm{L}-L}\right) & 13800 \mathrm{VAC} \\ \text { Line Current }\left(\mathrm{I}_{\mathrm{L}}\right) & \text { 321AAC }\end{array}$

Power Conditioning System for 15.8 MW. To consolidate power from eight PSOFC generator modules, and deliver that power to the AC grid, two systems of the type described above are paralleled as indicated in Figure 3-48. There is no change system voltage level, but the power delivered increases by a factor of two due to the increased current capability.

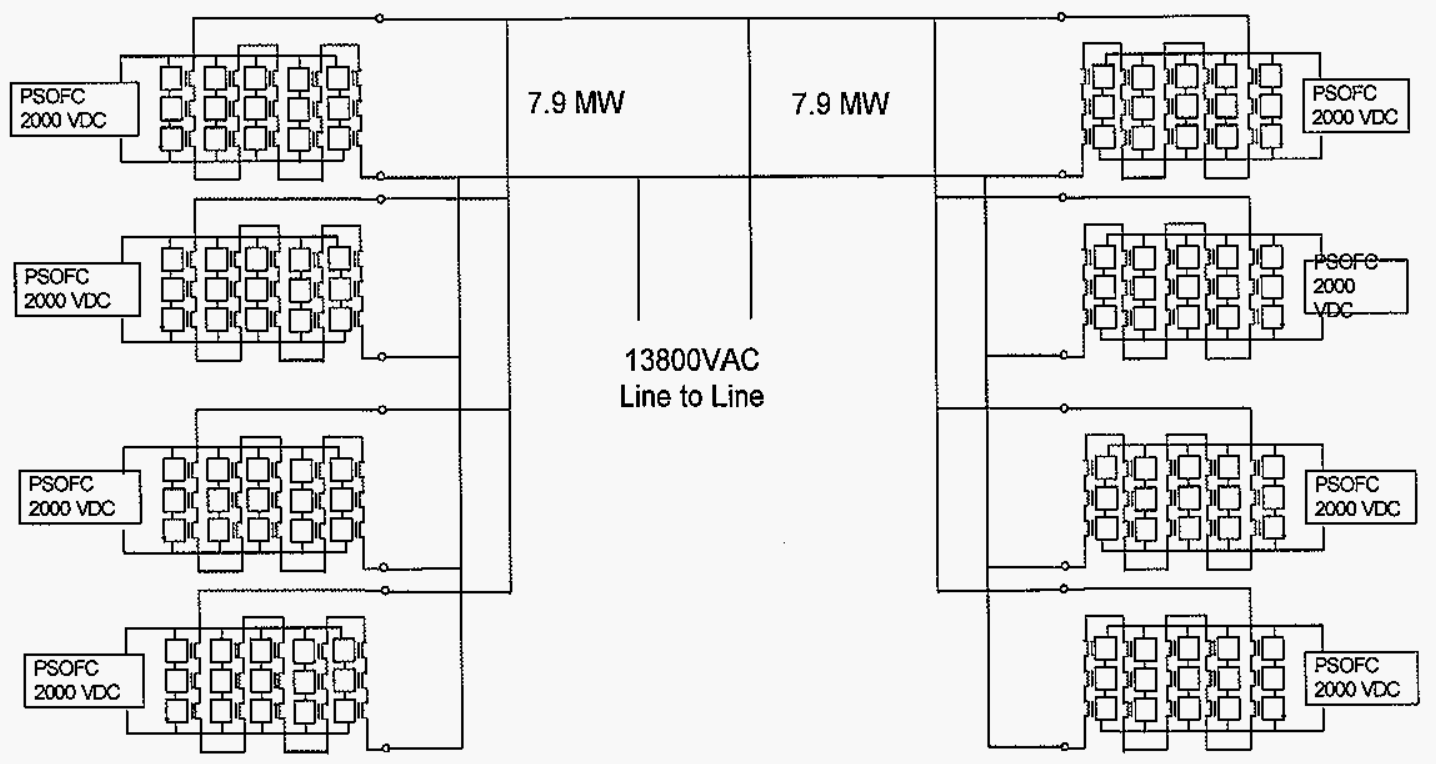

One Line Diagram

Single Phase Shown

Figure 3-48 - One-line diagram for power conditioning system associated with eight PSOFC modules.

Representation Only

Not Meant as Schematically Correct 
High Voltage Transition Section. The connection to the medium or high voltage power grid should be made through a High Voltage Transition Section. This cabinetry will house the connection panels for the PCS output voltages. At this juncture, secondary windings will be connected in parallel or series per system voltage requirements. In addition, high voltage, fused potential transformers (PTs) will be provided to step the high voltage down to control circuit level voltages. Current transformers (CTs) will be provided to monitor line currents.

High voltage $15 \mathrm{kV}$-class disconnect switches will be used to provide interlocked isolation to the Super Modules for routine maintenance. These switches will be fused to protect the system from load fault currents. The switches should have a visible indication of the switch position status. Operator safety interlocks such as lockouts and key interlock provisions should be included. Control circuitry will be used to interlock doors, offer over-current protection and provide personnel safety lock-outs. These switches are commercially available.

\subsubsection{Technical Discussion}

Technical Issues \& Problems. A number of design approaches were considered. The first approach considered was to provide multiple directly paralleled switching devices to provide the necessary primary current to an isolation transformer, which would step the voltage up to the distribution voltage level. This approach was dismissed since paralleling multiple devices would require extensive snubber circuits to counter switching voltage transients. Another issue is thermal management. Water-cooling would be required to provide enough cooling medium to keep the physical size to a minimum. This approach would not be flexible in its adaptability to other specifications. The decision was made to investigate a modular approach. Iterations were run to optimize the modules for maximum efficiency and cost.

Device Selection. The evaluation is based on commercially available IGBTs and the heatsink of choice, which is forced air-cooled. Dual IGBT modules were chosen as the device used in the design. These modules would be used as the switching device for $1 / 2$ of the inverter pole. The dual module will minimize switching transients. The maximum nameplate current rating for these devices is 300 or 400 amperes. Present voltage ratings are 600,1200 and 1700 Volts, collector to emitter (Vces). To maintain safe design 
levels under normal switching events, maximum peak voltage transients must be kept at $<90 \%$ of the Vces rating.

The first calculations were run using 1700 V IGBT modules. Two devices in series would be required to withstand the open circuit voltage requirement. These devices were not chosen because the switching losses at higher frequencies were too great. To lower the switching frequency would increase the cost of the filtering circuits, magnet components and DC bus capacitors.

$600 \mathrm{~V}$ IGBT modules were evaluated. Four devices in series would give a $2400 \mathrm{~V}$ withstand. This would push the design to above the $90 \%$ limit but may still be acceptable. However, the cost differential between the 600 and $1200 \mathrm{~V}$ modules does not offset the increased number of modules required for the same current density.

The 300 A rated devices were evaluated. As shown in Table 3.5, which summarizes the results of the device evaluation, the thermal management looks good but it will take $1 / 5$ as many devices to achieve the same current output.

The device number in Table 3.5 refers to a manufacturer or specific device. The different collector currents $(\mid c)$ reflect the current rating of the device. The Primary Line Current value is the required inverter current supplied to the isolation transformer. The Number of Parallel Inverters refers to the minimum number of inverters determined by the current density limitation of the device. Device 4 would be chosen based on the losses and current rating. 
Table 3.5 - IGBT Module Evaluation

\begin{tabular}{|l|cccc|cc|}
\hline \multicolumn{7}{|c|}{ IGBT Module Evaluation } \\
\hline \multicolumn{7}{|c}{ 1200V } \\
\hline Device & 1 & 2 & 3 & 4 & 5 & $600 \mathrm{~V}$ \\
Namplate Current Rating (Ic) & 300 & 300 & 400 & 400 & 300 & 400 \\
Primary Line Current & 232.7 & 232.7 & 232.7 & 232.7 & 232.7 & 227 \\
Number of Parallel Inverters & 5 & 5 & 4 & 4 & 5 & 4 \\
Vce sat(volts) & 2.7 & 2.1 & 2.4 & 2.15 & 1.6 & 1.5 \\
Turn-On Energy (mWs) & 21 & 19 & 24 & 23 & 7 & 10 \\
Turn-Off Energy (mWs) & 21 & 23 & 29 & 28 & 7 & 19 \\
Total Switching Energy (mWs) & 42 & 42 & 53 & 51 & 14 & 29 \\
Total Switching Loss @fc(W) & 420 & 420 & 530 & 510 & 140 & 290 \\
Conduction Loss/lGBT (W) & 209 & 162.3 & 223.5 & 200 & 124 & 139.5 \\
Diode Conduction Loss (W) & 120 & 120 & 153 & 158 & 87 & 107 \\
Diode RR Loss (W) & 112 & 86 & 115 & 110 & 33 & 25 \\
Total IGBT Loss (W) & 629 & 582.3 & 753.5 & 710 & 264 & 429.5 \\
Total Diode Loss (W) & 232 & 206 & 268 & 268 & 120 & 132 \\
Total Loss per Phase (W) & 861 & 788.3 & 1021.5 & 978 & 384 & 561.5 \\
Total H/S Losses -3 Ph.(W) & 2583 & 2364.9 & 3064.5 & 2934 & 1152 & 1684.5 \\
Delta Tj-c/IGBT (degrees C) & 23.5 & 21.8 & 18.8 & 17.75 & 11.88 & 19.3 \\
Delta Tj-c/Diode (degrees C) & 20.88 & 18.54 & 16.75 & 16.75 & 15 & 9.9 \\
Delta Tc-s/module (degrees C) & 16.35 & 14.97 & 19.41 & 18.6 & 7.29 & 10.66 \\
Tjunction @Ta=40 degrees C(C) & 135.73 & 130.31 & 129.96 & 128.1 & 109.17 & 114.86 \\
& & & & & & \\
\hline
\end{tabular}

The proposed modular/matrix approach is flexible in its application to various distribution voltages and power demands. By using proven designs in a matrix arrangement, reliability and cost effectiveness are maximized for the power density desired.

Inverter Rating. The inverter must be sized according to the power available and the output requirements. Referring to Figure $3-49$, which shows a single phase representation of a 7.9 MW section of the total power system, and assuming the output 


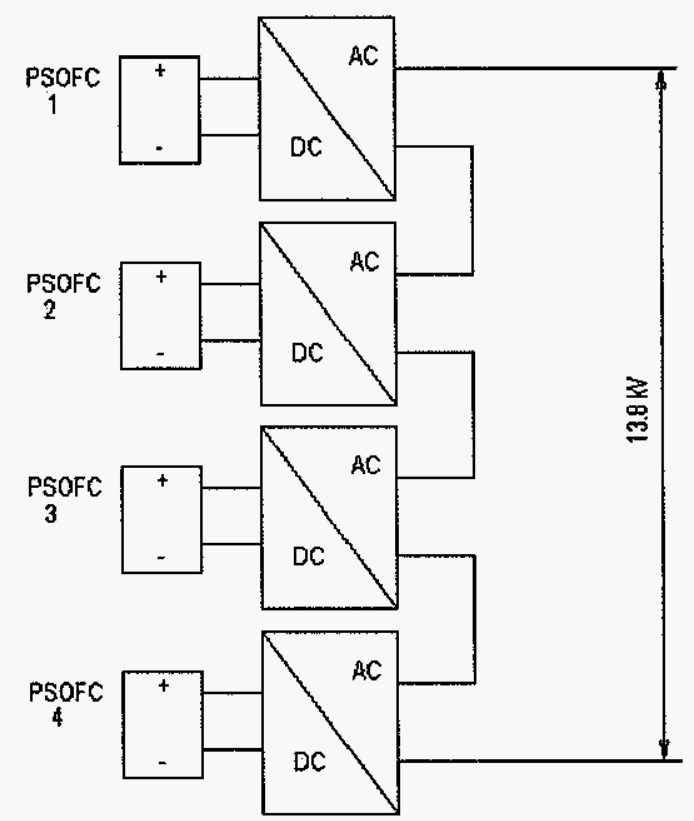

Figure 3-49 - Power conditioning concept for four PSOFC modules.

windings are connected in a wye, then the line to neutral voltage $\left(V_{L-N}\right)$ is

$$
V_{L-N}=\frac{13,800 \mathrm{~V}}{\sqrt{3}}=7967 \text { Volts }
$$

Each of the DC/AC converter sections must support $1 / 4$ of this voltage or $1991 \mathrm{~V}$ at 232.7AAC. Since three inverter sections are connected in a series configuration each section will have available $1 / 3$ of the working voltage of the PSOFC or 467 VDC. Interpretation of the PSOFC characteristic voltage/load curve indicates that adjustments in power component sizing must be made to accommodate a lower DC supply voltage and stray voltage drops must be taken into account. Assuming a worst-case insertion loss of $17 \mathrm{~V}$, and utilizing a PWM voltage waveform, causes a reduction in the effective RMS voltage delivered to the transformer primary. The resultant voltage is $318 \mathrm{~V}$ RMS. The deliverable power from the inverter is $128.2 \mathrm{~kW}$. 
The following illustration demonstrates the design flow and justification.

$$
\begin{aligned}
& P_{\text {available }}=2100 \mathrm{~kW} \\
& V_{\text {bus-min }}=1400 \mathrm{VDC} \\
& V_{\text {bus }}=V_{\text {bus-min }} / \# \text { of series inverters } \\
& V_{\text {drop }} \\
& V_{\text {net }}=V_{\text {bus }}-V_{\text {drop }} \\
& V_{\text {RMS }}=V_{\text {net }} \times 0.707 \\
& I_{\text {inV }}=232.7 \text { A } \text { RMS }
\end{aligned}
$$

lnvkW

Power

$$
\begin{aligned}
& V_{\text {bus }}=\frac{1400}{3}=467 \\
& V_{\text {net }}=467-17=450 \\
& V_{\text {RMS }}=0.707 \times 450=318 V_{\text {RMS }} \\
& \text { InvkW }=V_{\text {RMS }} \times I_{\text {inv }} \times \sqrt{3}=128.2 \mathrm{~kW} \\
& \text { Power }=15 \times 128.2 \mathrm{~kW}=1923 \mathrm{~kW}
\end{aligned}
$$

Available power from PSOFC

Minimum DC operating voltage from PSOFC.

Available bus voltage per series inverter.

Circuit voltage drops $(\approx 17 \mathrm{~V})$

Minimum peak switching voltage after circuit voltage drops.

Effective RMS voltage delivered using PWM control.

Maximum RMS current delivered to the transformer primary.

Maximum power delivered by inverter.

Inverter power times the number of inverters (15) per Super Module.

Snubbers. One of the most common problems encountered in high frequency, highcurrent-density inverter designs is the voltage control during turn-off and turn-on of the switching devices. Trapped energy in the circuit stray inductance manifests itself as damaging overshoot voltages, which can easily result in failed devices. One of the design decisions on how to minimize and possibly eliminate these voltage overshoots is to closely couple the DC bus to the inverter pole. To accomplish this, dual inverter modules are used. In addition, local DC bus capacitors will be used to supply load matched storage elements to each inverter section. Controlling the gate firing pulses may also aid in controlling the overvoltages by softer turn-on or turn-off gating characteristics. Should snubbers be necessary to control overshoots in the voltage, the snubbers will be an energy recovery type, which will put the energy back into the system actively rather than just dissipate the energy as losses. 


\subsubsection{Performance Characteristics}

The efficiency of the power conversion equipment is dependent upon two main components, the power switching devices and the magnets (both isolation transformers and filter inductors). As has been previously discussed, the IGBTs are chosen to optimize minimal losses. The transformers and inductors will be designed with special attention given to not only the fundamental frequency losses but the high frequency losses as well. Winding materials and techniques will be employed to minimize the DC and high frequency $I^{2} R$ losses. Core loss due to eddy currents (fringing) and hysteresis will be minimized by; 1) using proper core materials and 2) designing flux densities consistent with the efficiency goal.

\section{Loss Estimates}

Transformer Loss. Regardless of the transformer configuration (one large transformer driven by multiple inverters or each inverter having a dedicated transformer), the losses would remain a percentage of the overall kVA of the magnetics. The transformers will be designed with maximum efficiency and losses restricted to no more than $2 \%$.

IGBT Loss. IGBT loss is a function of the collector current, switching frequency and turn-on/ turn-off energy. Approximately $2800 \mathrm{~W}$ are dissipated per inverter as per Table 2. This loss would result in a total of $2.3 \%$ IGBT losses for the system.

Additional Losses. Ancillary losses are estimated at $0.5 \%$. These losses include but are not restricted to losses in the DC bus capacitors, control circuitry and wiring.

In conclusion, the total loss estimate is $\approx 5 \%$, corresponding to a PCS efficiency of approximately $95 \%$. It is considered that this value appropriately represents the efficiency with which the PCS converts DC power at the PSOFC module terminals to grid-quality $A C$ power at the grid interface.

\section{Power Factor}

The power factor will be 0.90 or better from 10 to $100 \%$ power. 


\subsubsection{Cost Estimate}

System Costs. The cost estimates for the overall system design are based on the inverter capacity rather than the actual delivered power. Since the inverter is designed to open circuit voltage specifications and delivered current, the inverter load line is defined as 2.96 MVA (2000 VDC, $1480 \mathrm{ADC}$ ). Utilizing limited quantity price breaks for $120 \mathrm{in}$ verters, the cost is estimated at $\$ 0.168 \mathrm{~W}$ or KVA based on PCS capacity. Relating this price to the delivered power is a direct ratio of the design capacity to delivered power. This ratio would put the cost of delivered power at approximately $\$ 0.24 \mathrm{~W}$ delivered power to the grid.

Increased sales volume would have an impact in the material cost of about a maximum of $20-30 \%$ savings. Following typical business profit/cost ratios, this reduction in material cost would impact sales pricing by approximately $10 \%$ since the material cost accounts for about $30-32 \%$ of the sales price. Additional savings may be realized by reduced labor costs as efficiency increases with familiarity based on volume. This reduction would impact labor content, which would generally account for $10-15 \%$ of the sales price. A reasonable reduction in labor costs could account for $10 \%$ reduction in manhours. A $20 \%$ reduction, representing volume effects on materials and labor, was applied in developing an appropriate commercial inverter cost estimate. The resulting inverter cost estimate is $\$ 397,800$ per PSOFC generator module.

Transformer Costs. The magnetic costs are dependent on the design approach taken. The least expensive approach would use a high kVA, utility type transformer configuration. Typical distribution configurations would use $1 \phi$ transformers connected in a three phase arrangement. These transformers would be "off the shelf" items and would reflect a commodity pricing structure. Utility transformers are low cost items with prices in the \$5-6/kVA range. This magnet approach is not practical for an inverter matrix approach because the primary currents would be in the kiloampere range for these power levels. This would require direct paralleling of the IGBTs, and since IGBT ratings are limited, the control configuration becomes extremely difficult to manage. The multiple transformer approach as discussed makes the control more manageable and economic, but the transformer costs increase to about $\$ 22 / \mathrm{kVA}$.

An avenue that could be investigated would involve a consolidation of the magnetics by having one transformer core with multiple isolated primary windings. The cost would be 
impacted by a reduction in overall weight (less core material than the multiple, single transformers), but the labor costs increase because the process is no longer a continuous winding design (stop and start). Each PSOFC module group of four modules could have one transformer with multiple windings rated for 2.1 MVA. This would drive the transformer costs down. The actual savings would have to be determined at time of order placement.

Designs could be based on copper or aluminum windings. The cooling specification could be for convection, forced air-cooling or oil filled. This price will vary as the market varies with copper and aluminum raw material market value. Quantity buys of a similar design could have a significant impact on this figure. The modular approach proposed would facilitate this quantity pricing structure for the transformers.

At $\$ 22 / k V A$, the estimated transformer cost per PSOFC module is $\$ 46,200$.

High Voltage Section. The $15 \mathrm{kV}$-class disconnect switches needed to isolate the PCS from the utility grid are commercially available from a variety of manufacturers. List pricing is around $\$ 5000$. Options will increase this price. The options available include, but are not limited to, motor operated mechanisms, fuse failure indication and customer interface contacts.

The high voltage section should be outsourced and the pricing would reflect prevailing prices.

On the basis that each $10 \mathrm{MWe}$-class power system would require two disconnect switches, and allowing for options, the estimated switch cost is $\$ 5000$ per PSOFC module. The total estimated PCS and disconnect-switch cost is therefore $\$ 449,000$ per PSOFC module, which corresponds to approximately $\$ 215 / \mathrm{DC} \mathrm{kW}$.

\subsubsection{Physical Dimensions}

The inverters will be housed in modified NEMA 12 enclosures as indicated in Figure 3-50. The enclosure dimensions for one Super Module would be approximately $2.3 \mathrm{~m}$ (h), $1 \mathrm{~m}(\mathrm{w})$, and $0.9 \mathrm{~m}(\mathrm{~d})[7.5 \mathrm{ft}(\mathrm{h}), 3.3 \mathrm{ft}(\mathrm{w})$, and $3 \mathrm{ft}(\mathrm{d})]$. 


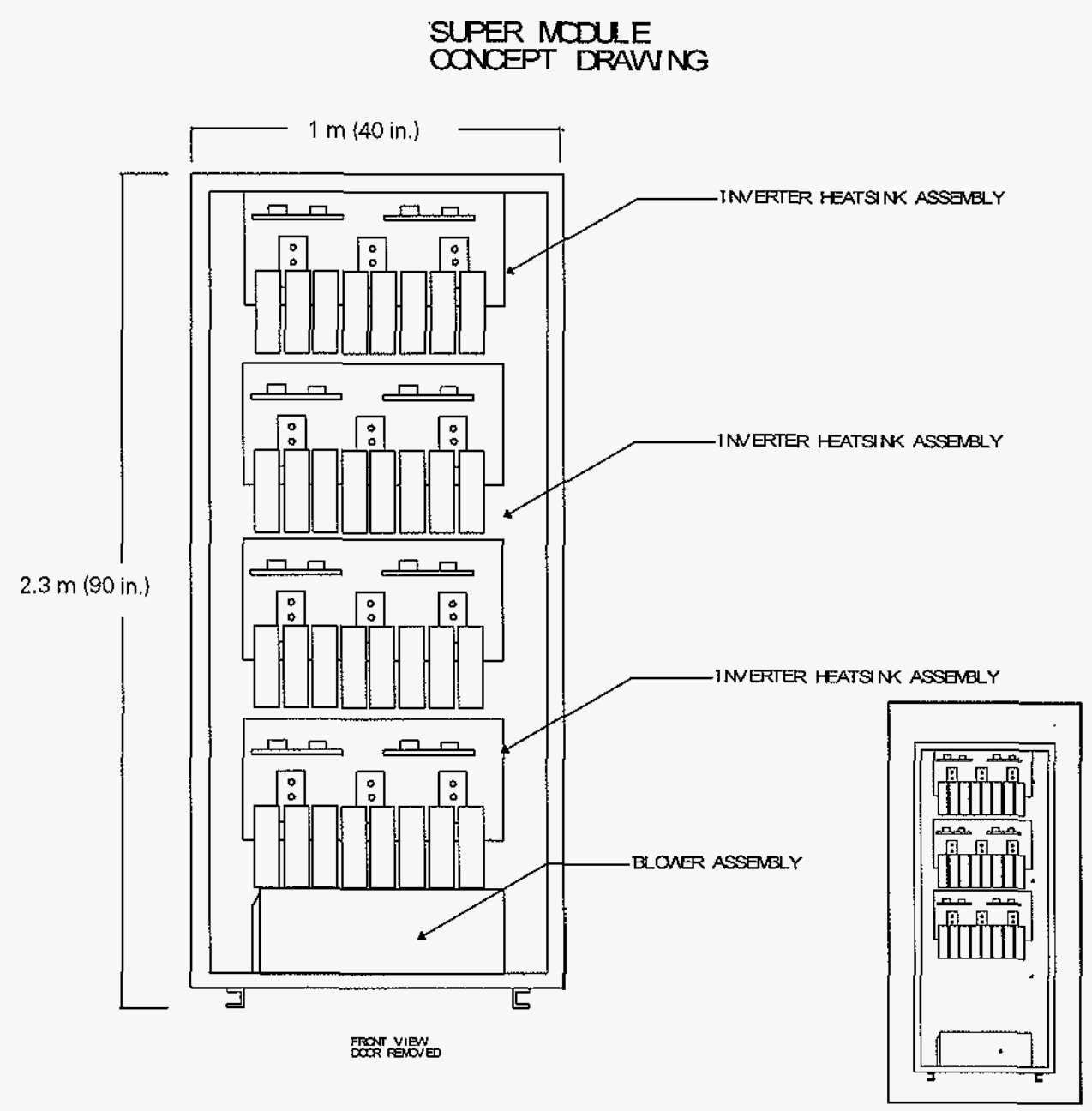

Figure 3-50 - Inverter cabinet concept.

Four cabinets would be required by each PSOFC generator module. Three would house four inverters each, as shown in Figure 3-50, while the fourth cabinet would contain three inverters (inset). The PCS cabinetry arrangement concept for four PSOFC modules (one PSOFC/ATS-GT power block) is depicted in Figure 3-51.

These drawings are for concept depiction only, and they indicate the cabinet volume to house the inverter components. During the detail design, every effort should be made to optimize the physical arrangement of the inverters so that the connection points to the PSOFC provide for the shortest bus distances possible. This would minimize DC losses and lessen material and installation costs. 


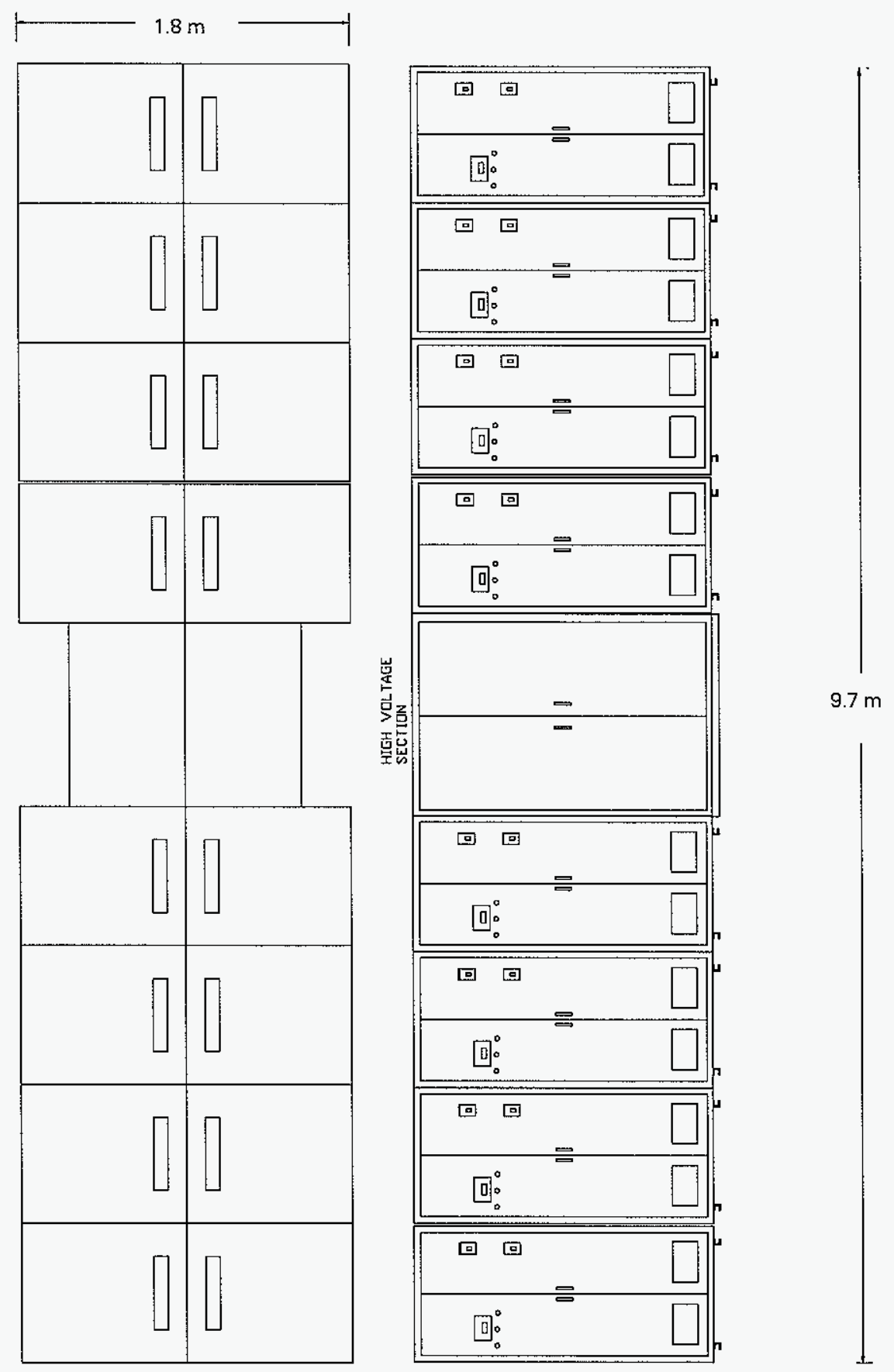

Figure 3-51 - PCS cabinet concept for four PSOFC generator modules. 


\subsubsection{Instrumentation and Controls System}

The PSOFC modules and auxiliary equipment will be equipped with instrumentation and controls that provide for automatic operational control, and with manual capabilities, for plant operation. The instrumentation and controls $(I \& C)$ system will also provide for remote monitoring and operations, data collection, and diagnostics.

\subsubsection{Hardware}

PLC. The heart of the instrumentation and controls system is the programmable logic controller (PLC). The PLC provides for safe, reliable, and steady power system operation over its operating range. The controllers will scan inputs, execute preprogrammed logic, and set the state of outputs based on the control strategy.

Input/Output Modules. The $1 / 0$ modules will link the instrumentation signals to the PLC. Thermocouples, voltage sensors, and current sensors will provide raw analog data through the $1 / O$ modules. The PLC converts the signals to digitized engineering units for display, and it provides for an appropriate output response to various system actuators.

Communication Modules. The communication modules will link the PLC to one or more PSOFC Control/Data computers. In addition, the communication modules will provide the control signals to the PCS for power control.

Electrical Control Hardware. The electrical control hardware is composed of those components that gather the input and output signals and respond to the needs of the main PLC process controller. Power supplies, signal conditioners, relays, current and voltage sensors, etc., comprise the electrical control hardware. These components form the control circuits that implement the commands from the PLC. The electrical control hardware also provides for continuous control of auxiliary devices such as blowers, valves, and the PSOFC generator/gas turbine electrical loading. The components will be packaged for efficient space utilization and convenient maintenance access.

Operator Interface. An operator interface computer will be supplied as part of the $1 \& C$ system, to provide a display of the critical PSOFC generator parameters, and to allow for operator input of control parameter setpoints. The operator interface will consist of a computer, graphics display monitor, large-capacity hard drive, and printer. Provisions for alarm monitoring/logging, operator input for state transition, manipulation of remote 
alarm action and control parameter setpoints will be incorporated in the operator interface.

\subsubsection{Software}

The I\&C system is a PLC based system that stores and uses information about the status of the PSOFC generator modules, the gas turbine systems, and the support systems. Data are read continuously and updated by the control system. Some data are also directed to, or taken from, the operator interface. The system software specifies the response to data, and controls the state of the generator. The system detects alarm conditions, and controls both modulating and discrete devices.

The power system will have a table of pre-defined operating states. For example, PreOp, Purge, Heat, Load, Run, Cool, Stop, and SStop are typical PSOFC system states. The control system software contains the logic that determines the operating state of the PSOFC generators and all valid transition states. The control system will allow the operator to transition from the present state to a valid transition state only.

Discrete control logic will be used to change the states of control solenoid valves, and to provide valve status information to the operator.

Analog control logic will be set to detect out-of-limit alarm signals. Response to an alarm signal will depend on the severity of the alarm. All alarms warn the operator. Others may result in a shutdown of the system.

Operator interface software package will be provided for supervisory control and data acquisition.

\subsubsection{Electrical Distribution System (EDS)}

The PSOFC electrical distribution system (EDS) refers to the distribution of AC power to the instrumentation and control systems, and to any support system loads. A one line diagram of the EDS conceptual design for one PSOFC/ATS-GT power block is shown in Figure 3.52. It does not include the PSOFC generator DC output power, the AC power 


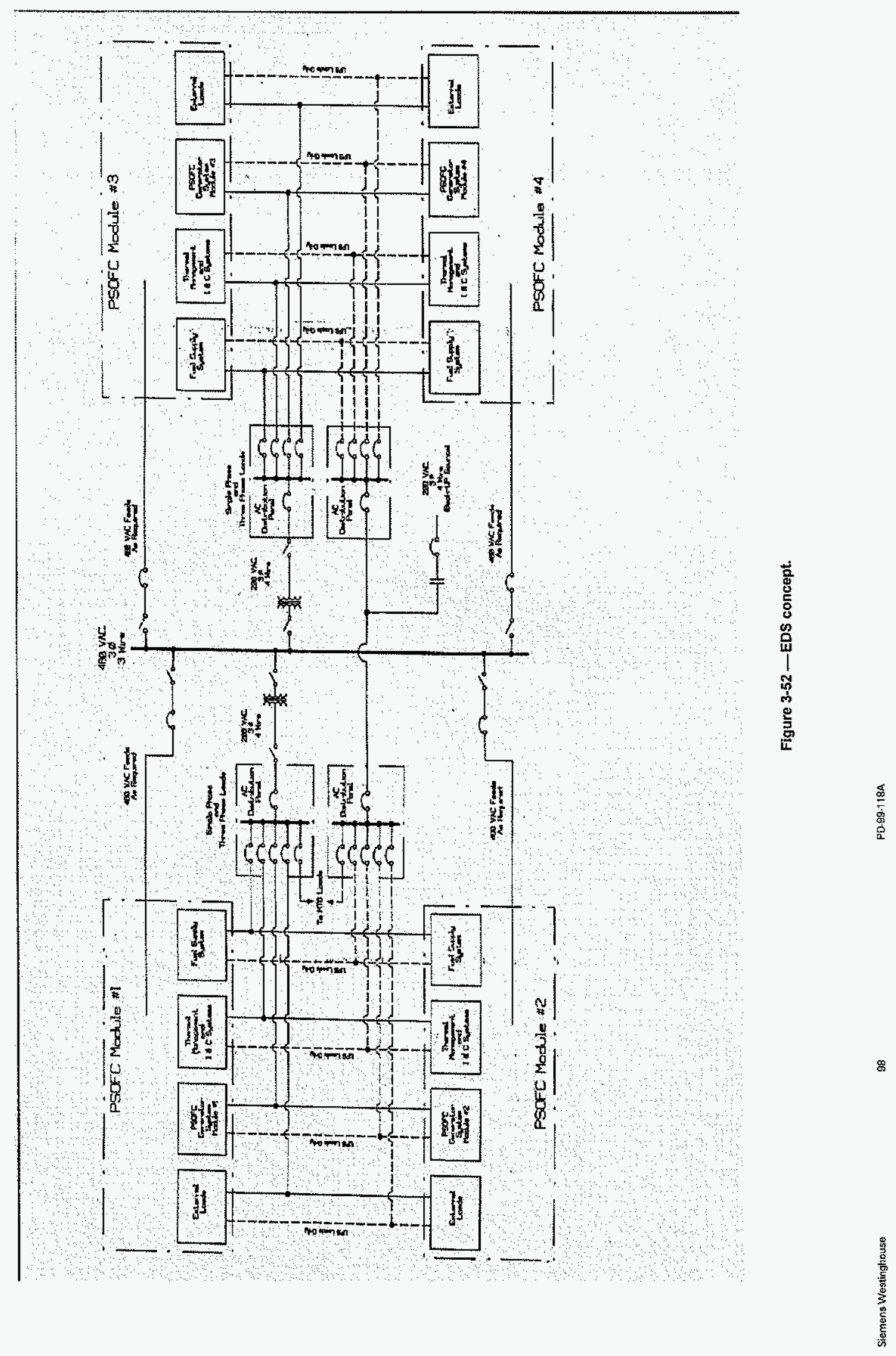


out of the inverter, or the gas turbine $A C$ output power. The requirements of the EDS system are to provide 480 VAC, three phase power, 208 VAC three phase power, and 120 VAC single phase power to the PSOFC generator auxiliary system components. The power source of the EDS main circuits and branch circuits, is a step down transformer that is tied to the primary high voltage AC bus. The transformer lowers the bus voltage from the grid $13.8 \mathrm{kV}$ to $480 \mathrm{VAC}$, three phase, for distribution and use within the $1 \& \mathrm{C}$ systems of the generating plant. A further reduction from $480 \mathrm{VAC}$ is required to feed the 208 VAC, three phase loads, and the 120 VAC, single phase loads.

The 480 VAC bus may be required to supply three phase power for the heavier PSOFC loads, including pumps, compressors, and other internal service loads and house loads. The 480 VAC system feeds will have manual disconnects for maintenance, and circuit breakers for electrical protection in the event of a system fault.

A 208 VAC and 120 VAC distribution panel will be provided for the distribution of power to heaters, steamers, boilers, dc power supplies, solenoid valves, and all other low voltage components required to monitor and control the PSOFC generator system operation. The panel will be supplied with, and located within, the PSOFC system to distribute power to the loads. In addition, 208 VAC, three phase, and 120 VAC, single phase back-up power will be made available for critical PSOFC system loads in the event of a grid outage. Should an outage occur, the non-essential loads will be disconnected from the 480 VAC bus, and only those required loads will be fed from the back-up supply. The back-up supply will continue to power the essential components until grid power is restored, or an orderly shut-down of the PSOFC system occurs.

\subsubsection{Fuel Processing System}

The supply of natural gas is assumed to be within the conventions of the U.S. distribution system. In the U.S., the distribution mains range in size from $0.508 \mathrm{~m}$. (20 in.) to $1.07 \mathrm{~m}$. (42 in.), and contain gas at $13.8 \mathrm{barg}(200 \mathrm{psig})$ to $103.4 \mathrm{barg}$ (1500 psig). Compressor stations are normally located $80 \mathrm{~km}$ (50 miles) to $100 \mathrm{~km}$ (60 miles) apart and occasionally as far as $300 \mathrm{~km}$ (180 miles). Gas flows in the mains at $24 \mathrm{~km} / \mathrm{hr}$ (15 mph or $22 \mathrm{fps}$ ). The natural gas is reduced in pressure at the local natural gas supply utilities. These utilities add an odorant and distribute the gas through lines at about 4.1 barg (60 psig). The pressure at residential customers varies from 17 mbarg to 4 barg $(0.25$ psig 
to $60 \mathrm{psig}$ ). The most commonly used gas piping is rated to operate at 6.9 barg (100 psig). For this study, it was assumed that the supply of natural gas at the plant site is at 1.03 barg (15 psig) and contains a sulfur-based odorant. The gas line size needed for a $20 \mathrm{MW}$ plant is $30.5 \mathrm{~cm}$ (12 in.) at 1.03 barg (15 psig) supply pressure.

On the plant site, the natural gas is filtered in an automatic duplex inlet filter (see Figure 3.10). One side of the filter is on standby while the other side performs the filtering. When the differential pressure across the filter reaches the set pressure corresponding to a dirty filter element which needs to be changed, the automatic duplex filter uses the gas supply pressure for the motive force to actuate the three way valves and divert the flow through the standby side. A dirty filter indication is sent to the control system and filter element changing is scheduled. Filter element changing is performed with the unit on line and fuel flow is not interrupted.

The natural gas enters the inlet of one $100 \%$ capacity natural gas compressor. The compressor discharges to an accumulator which provides a pulsation dampening function as well as a reservoir of natural gas at compressor discharge pressure to ride through supply interruptions when the compressor stops and goes off line when the accumulator high pressure set point is attained. The compressor operates on accumulator pressure control, starting on low pressure and stopping on high pressure. The compressor design flow rate is set slightly higher than the maximum plant fuel consumption rate. During normal plant operation, the compressor will be idle about one fourth of the time.

From the natural gas accumulator, the fuel passes through a gas recuperator. Hot natural gas from the outlet of the desulfurizer system exchanges heat with the cooler natural gas leaving the natural gas accumulator. This preheated natural gas then leaves the gas recuperator at a temperature of $375^{\circ} \mathrm{C}\left(700^{\circ} \mathrm{F}\right)$.

The natural gas desulfurizer includes one hydrodesulfurization catalyst vessel in series with two series-mounted, 100\% capacity, adsorbent (zinc oxide) vessels. At the entrance to the catalyst vessel, a very small quantity of hydrogen, about $1 \%$ (by volume) of the fuel flow, is mixed with the natural gas. The mixture is electrically heated to raise its temperature to near $400^{\circ} \mathrm{C}\left(750^{\circ} \mathrm{F}\right)$. Each adsorbent vessel includes an electrical gas heater under automatic temperature control to ensure that the zinc oxide bed and natural gas are at suitable temperature for effective sulfur adsorption. 
The catalyst is cobalt-molybdenum, which promotes the conversion of complex sulfur compounds to $\mathrm{H}_{2} \mathrm{~S}$. The gas then flows to the adsorbent vessels. Zinc oxide is ineffective for $\mathrm{H}_{2} \mathrm{~S}$ adsorption at ambient temperatures, but it is very effective at temperatures above $277^{\circ} \mathrm{C}\left(530^{\circ} \mathrm{F}\right)$. Preheating the natural gas/hydrogen mixture in the gas recuperator, followed by supplemental electric heating to the optimum operating temperature of $400^{\circ} \mathrm{C}\left(750^{\circ} \mathrm{F}\right)$, permits the use of minimum sized adsorbent beds.

Sulfur removal effectiveness is checked monthly with the drawing of a sample from the line between the adsorbent vessels. When the sample shows detectable sulfur, the valve alignment is set to enable the on-line replacement of the spent upstream adsorbent and its return to service as the downstream adsorbent.

\subsubsection{Gas Supply Systems}

The power system includes both nitrogen and hydrogen generating equipment. The nitrogen is stored on-site in pressurized cylinders until needed. The hydrogen is produced as demanded and not stored, thereby reducing fire protection concerns.

\subsubsection{Nitrogen Supply System}

The inlet to the natural gas compressor accumulator has a connection to a nitrogen purge system (see Figure 3.10). The nitrogen supply system is normally isolated from the natural gas supply and is activated under two conditions:

- Emergency or safety stop (SSTOP)

- Maintenance of natural gas system components

When activated, the nitrogen purge system connection isolation valve and gas vent valve both automatically open. Nitrogen gas from a pressurized tank flows through the accumulator, gas recuperator, desulfurizer vessels and outlet duplex filter to the vent. This dilutes and forces the natural gas out of the system until a nonflammable concentration of gas remains.

SOFC Cover Gas. The SOFC stacks require an inert or reducing environment on the cell fuel side when the stack temperature approaches and exceeds $600^{\circ} \mathrm{C}\left(1100^{\circ} \mathrm{F}\right)$. During 
normal operation, thus environment is provided by the fuel. When fuel is not present, during startup and shutdown operations, nitrogen cover gas provides the required inert atmosphere. A commercially available nitrogen generating system produces this cover gas. This system uses a selective membrane to separate nitrogen from the other constituents of air.

A pre-packaged, skid mounted nitrogen generation system produces nitrogen gas whenever demanded by the low-pressure control in the nitrogen storage accumulator. The system stops when high accumulator pressure is achieved. The nitrogen generating equipment may occasionally operate to refill the accumulator if there are leaks. The nitrogen system is sized to produce in seven days a sufficient quantity of nitrogen to support one plant shut down. The storage accumulator has provisions to be filled with nitrogen from an external source, if necessary.

Nitrogen generation uses commercially available equipment that consumes electricity and compressed air to generate nitrogen gas. The nitrogen is separated from the compressed air through a selective membrane. The nitrogen is $98 \%$ pure. Nitrogen flows under its own pressure from the accumulator without the need for additional pumping. As the nitrogen is generated, hydrogen (about $4 \%$ by volume) is added to scavenge impurity oxygen.

\subsubsection{Hydrogen Supply System}

A pre-packaged, skid-mounted hydrogen generation system produces hydrogen continuously during plant start and normal operation. During normal operation, the hydrogen is mixed with the natural gas to form a gas/hydrogen mixture with approximately $1 \%$ (vol) hydrogen. This mixture is heated and delivered to the cobalt-molybdenum catalyst in the fuel desulfurization system.

The hydrogen generation process uses commercially available equipment that consumes electricity and electrolyzes water to generate the hydrogen gas at the maximum rate required during power system operation. This gas is produced as needed, and is compressed and stored as it flows from the electrolysis chamber. 


\subsubsection{Balance of Plant (BOP) Equipment}

\subsubsection{Startup Boiler}

A natural gas heated boiler is supplied to provide a source of steam for plant start up. This commercially available, prepackaged, skid mounted boiler is a complete selfcontained system with all auxiliary components and instrumentation. Integration with the SOFC power system requires connections with natural gas, demineralized water, and electric power supplies. The steam outlet is piped to the SOFC generator modules, and the boiler blowdown line is piped to a drain.

Boiler operation is manually controlled for the short time that it is needed. The boiler is used only for plant startup, and it is drained and laid up dry for prolonged periods of inactivity during normal power system operations.

\subsubsection{Auxiliary Air Compressor}

The auxiliary air compressor system includes an internal combustion engine driven compressor, inlet air filter, compressed air filter/dryer and air accumulator plus the necessary engine starter, instrumentation and controls. The dual-fuel engine can use either natural gas or propane gas. The primary engine fuel is the normal natural gas supply. In the event of loss of natural gas supply, the engine automatically switches over to propane, obtaining that fuel from a pressurized, on-site, liquid-propane storage vessel.

The compressor operates to fill an air accumulator. The compressor engine starts and stops based upon pressure control signals from the accumulator. The auxiliary air compressor is sized to provide the airflow to cool the cell stacks during a shutdown operation. Stack cooldown to less than $260^{\circ} \mathrm{C}\left(500^{\circ} \mathrm{F}\right)$ occurs in about three hours.

The compressed air accumulator provides a pulsation dampening function at the compressor outlet and a steady flow of auxiliary air when engine operation pauses momentarily during automatic fuel supply changeover.

\subsubsection{Water Treatment and Storage}

Potable water is taken from the site municipal supply, filtered, deionized, and stored. The storage volume is sized to provide the water needed by the hydrogen generating 
system and startup boiler system during a normal plant start. The storage tank level is automatically maintained by a level-sensing supply-water control valve.

The water system includes a pump to transfer deionized water from the storage tank to the hydrogen generating system and startup boiler.

\subsubsection{Process Air Piping}

The design of the process air and gas piping to be installed between the gas turbine and the PSOFC generator modules must satisfy several criteria:

- The piping wall temperature should be less than or equal to $371^{\circ} \mathrm{C}\left(700^{\circ} \mathrm{F}\right)$. This criterion allows the use of standard piping material instead of higher cost alloys rated for high temperatures. All standard piping steels suffer no loss of strength until the working temperature exceeds $400^{\circ} \mathrm{C}\left(750^{\circ} \mathrm{F}\right)$.

- The external insulation jacket surface temperature must be at or less than the OSHA 29 CFR $1910.107(I)(7)$ limit of $65.6^{\circ} \mathrm{C}\left(150^{\circ} \mathrm{F}\right)$. Conventional jacketed, mineral wool is suitable for this application.

- The speed of the air inside the inner insulation is less than $30 \mathrm{~m} / \mathrm{s}(100 \mathrm{ft} / \mathrm{s})$. This air speed does not require an internal protective liner for the insulation and permits the use of less expensive, commonly available insulating materials without concern for erosion of the surface. Vacuum formed alumina-silica fiber insulation was found to have good thermal resistance and appropriate abrasion resistance.

Applying these criteria, the nominal diameter of the piping selected for the SOFC air inlet and exhaust outlet headers is $97 \mathrm{~cm}$ (38 in.), and the diameter of the branch pipes that connect the headers and the SOFC modules is $71 \mathrm{~cm}$ (28 in.). For both pipes, the internal-insulation thickness is $19.4 \mathrm{~cm}$ (7.63 in.), and a thickness of $7.6 \mathrm{~cm}(3 \mathrm{in}$.) was selected for the external insulation.

\subsubsection{Plant Operation}

Plant operations are summarized in the following sections, including plant startup, operation, normal shutdown, and emergency shutdown. 


\subsubsection{Preparations for Normal System Start}

The following services are available:

- Natural gas compressor is operational and gas supply pressure is in range

- Auxiliary air compressor is operational and compressed air accumulator pressure is in range

- Demineralized water storage tank is filled to required level with deionized water

- Nitrogen system accumulator pressure is in range

- Hydrogen system is operational

System Configuration:

- Initial system status - unpressurized at ambient temperature

- Fuel piping - fuel supply control valves for all SOFC modules are closed. Fuel supply control valves for both air heaters are closed. Combustor fuel supply is off. Desulfurizer vent to atmosphere is closed.

- Vessel fuel vent system piping - vessel fuel vent system isolation valves from each SOFC module is closed.

- Auxiliary air compressor piping — Isolation valves to SOFC module air supply headers are closed.

- Cover gas piping - Isolation valves to SOFC module fuel supply headers are closed.

Operator Actions Sequence. Start turbine air compressor motor. When airflow through turbine is established, fire the combustor to bring the turbine to normal speed. Allow the turbine/generator to free wheel as the flow of air passes through the SOFC vessels to the turbine inlet.

Fire the air heater on the SOFC vessel inlet header. Control firing to limit the air heater exit air temperature to $500^{\circ} \mathrm{C}$ above the lowest temperature SOFC vessel stack.

When the highest temperature SOFC stack reaches $500^{\circ} \mathrm{C}$, open the cover gas system supply isolation valves to admit inert gas to the header that feeds the SOFC modules.

Begin adding steam to the SOFC generator modules, via the fuel supply system, when combustion zone temperatures reach $600^{\circ} \mathrm{C}$. 
When the SOFC vessels reach $675^{\circ} \mathrm{C}$ stack temperature, begin to draw current. Start low fuel flow. Slowly increase the power being drawn from the stack. Fuel flow increase will automatically follow current increase.

Isolate cover gas system from the SOFC vessels headers when the current from each stack reaches $300 \mathrm{~A}$. Fuel reformation and recirculation is sufficient to maintain a selfsustaining reducing atmosphere in the fuel region.

Begin to load the turbine generator. Increase the power drawn as the temperature increases in order to maintain airflow (shaft speed) at design value(s).

Turn off air heaters when the current from each stack is approximately $460 \mathrm{~A}$. At this time the recuperated air temperature is self-sustaining.

\subsubsection{Normal Operation}

The plant run state is entered when the stack temperature achieves $850^{\circ} \mathrm{C}$ and the current draw is $300 \mathrm{~A}$ from each stack. During normal operation, the operator has control of:

- Fuel utilization

- Current

- Stack temperature

Setting the control system set points for any two of these parameters determines the third.

The plant is expected to operate unattended for 50 weeks with periodic remote monitoring and control adjustments made via telephone modem access for a remote location. At the end of the scheduled normal time, operators return to the site to supervise a normal shutdown.

While most maintenance will be performed during the annual scheduled plant outage, some activities may need to be performed during normal operation. The replacement of natural gas desulfurizer adsorbent will normally be performed during the annual maintenance period. On-line absorbent changeout is done as discussed earlier. The duplex filters on the inlet and outlet of the desulfurizers will normally last for years before de- 
veloping enough filtrate cake to produce the pressure drop to trigger automatic change over. The duplex filter changes position to pass flow through the standby filter when across the filter media increases to the dirty filter set point. Spent filter elements will be changed as the need arises.

\subsubsection{Normal Shutdown}

Start Cover Gas System. When cover gas system is fully operational, the turbine AC generator is unloaded.

Shutting down the SOFC stacks is accomplished with simultaneous control actions to:

- Stop natural gas flow to the stacks

- Start cover gas system flow to the stacks

- Unload current to $\sim 35 \mathrm{~A}$ per stack and transfer power to stack energy dissipaters

The turbine will continue to rotate and produce compressed air flow, running on the stored heat from the stacks. After system cooling has proceeded and the turbine/ compressor approaches stall, the generator will be used as a motor to drive the compressor.

Stop flow of cover gas system when stack temperatures are less than $500^{\circ} \mathrm{C}$.

Continue the supply of auxiliary air until stack temperatures are less than $100^{\circ} \mathrm{C}$.

Automatic Stop Conditions. The plant will automatically enter STOP when any of the following conditions are sensed:

- Low generator voltage

- Low generator current

- High stack temperature for 10 minutes

- Low UPS battery voltage

The sequence of automatic shutdown actions is the same as if the shutdown were initiated by manual control action. 


\subsubsection{Normal Maintenance}

At the end of a normal run time, the plant is shut down for normal maintenance. The maintenance period is two weeks. During this period the activities include:

- inspection of turbine and generator rotating parts

- lubricating oil changes

- air filter element replacement

- instrumentation and control system calibrations

- repair or replacement of failed or improperly operating components

- fire protection system inspection and testing

\subsubsection{Emergency Operations}

To accommodate the occurrence of abnormal situations, the plant control system is equipped to automatically take control actions. The priorities for automatic emergency control actions are 1) personnel protection and 2) property protection. The extent of emergency conditions that are accommodated are shown in Table 3.6.

It is assumed that no two failures occur simultaneously. 
Table 3.6 - Plant Emergency Situations

\begin{tabular}{|c|c|c|c|c|}
\hline \multirow[b]{2}{*}{ Plant Mode } & \multicolumn{4}{|c|}{ Control Sequence } \\
\hline & Loss of Grid & SOFC Failure & $\begin{array}{c}\text { Turbine or } \\
\text { Generator Failure }\end{array}$ & $\begin{array}{c}\text { Cover Gas } \\
\text { System Failure }\end{array}$ \\
\hline Startup & $\begin{array}{l}\text { Start auxiliary air com- } \\
\text { pressor } \\
\text { Enter aux. air stack cool- } \\
\text { ing sequence } \\
\text { Maintain cover gas flow } \\
\text { until stack temperatures } \\
\text { are less than } 500^{\circ} \mathrm{C}\end{array}$ & $\begin{array}{l}\text { Enter normal } \\
\text { stop sequence }\end{array}$ & $\begin{array}{l}\text { Start auxiliary air } \\
\text { compressor } \\
\text { Enter aux. air stack } \\
\text { cooling sequence } \\
\text { Maintain cover gas } \\
\text { flow until stack tem- } \\
\text { peratures are less } \\
\text { than } 500^{\circ} \mathrm{C}\end{array}$ & $\begin{array}{l}\text { Depressurize } \\
\text { Vent Fuel Side } \\
\text { Start primary air } \\
\text { cooling sequence } \\
\text { Reestablish purge } \\
\text { with nitrogen }\end{array}$ \\
\hline $\begin{array}{l}\text { Normal } \\
\text { Operation }\end{array}$ & $\begin{array}{l}\text { Divert turbine/generator } \\
\text { power to resistance } \\
\text { banks, SOFC to open } \\
\text { circuit. }\end{array}$ & $\begin{array}{l}\text { Enter normal } \\
\text { stop sequence }\end{array}$ & $\begin{array}{l}\text { Start auxiliary air } \\
\text { compressor } \\
\text { Enter aux. air stack } \\
\text { cooling sequence } \\
\text { Start and maintain } \\
\text { cover gas flow until } \\
\text { stack temperatures } \\
\text { are less than } 500^{\circ} \mathrm{C} \\
\end{array}$ & N/A \\
\hline $\begin{array}{l}\text { Normal } \\
\text { Shutdown }\end{array}$ & $\begin{array}{l}\text { Start auxiliary air com- } \\
\text { pressor } \\
\text { Enter aux. air stack cool- } \\
\text { ing sequence } \\
\text { Maintain cover gas flow } \\
\text { until stack temperatures } \\
\text { are less than } 500^{\circ} \mathrm{C}\end{array}$ & $\begin{array}{l}\text { Continue nor- } \\
\text { mal shutdown } \\
\text { sequence }\end{array}$ & $\begin{array}{l}\text { Start auxiliary air } \\
\text { compressor } \\
\text { Enter aux. air stack } \\
\text { cooling sequence } \\
\text { Maintain cover gas } \\
\text { flow until stack tem- } \\
\text { peratures are less } \\
\text { than } 500^{\circ} \mathrm{C}\end{array}$ & $\begin{array}{l}\text { Depressurize } \\
\text { Vent Fuel Side } \\
\text { Start auxiliary air } \\
\text { compressor } \\
\text { Purge with nitro- } \\
\text { gen }\end{array}$ \\
\hline
\end{tabular}




\subsection{Power System Installed Cost and Cost of Electricity Estimates}

Table 3.7 summarizes the development of the power system installed cost, and in Table 3.8 the system COE estimate is developed. Mature-product conditions (circa 2008) are assumed. Input for the COE analysis is identified in Table 3.8 .

Table 3.9 provides the COE estimate for the conventional power generation technology, a $20 \mathrm{MWe}$-class gas turbine/steam turbine combined cycle. At the reference fuel cost, \$3.00/MMBtu, the PSOFC/ATS-GT power system COE estimate is lower than the conventional-technology COE estimate by approximately $6 \%$. Figure 3-53 shows the effect of fuel cost on the COE estimates for the PSOFC/ATS-GT and conventional-technology power systems. Due to its higher operating efficiency, the PSOFC/ATS-GT system will exhibit increasing COE advantage as the fuel cost rises above the $\$ 3$ value.

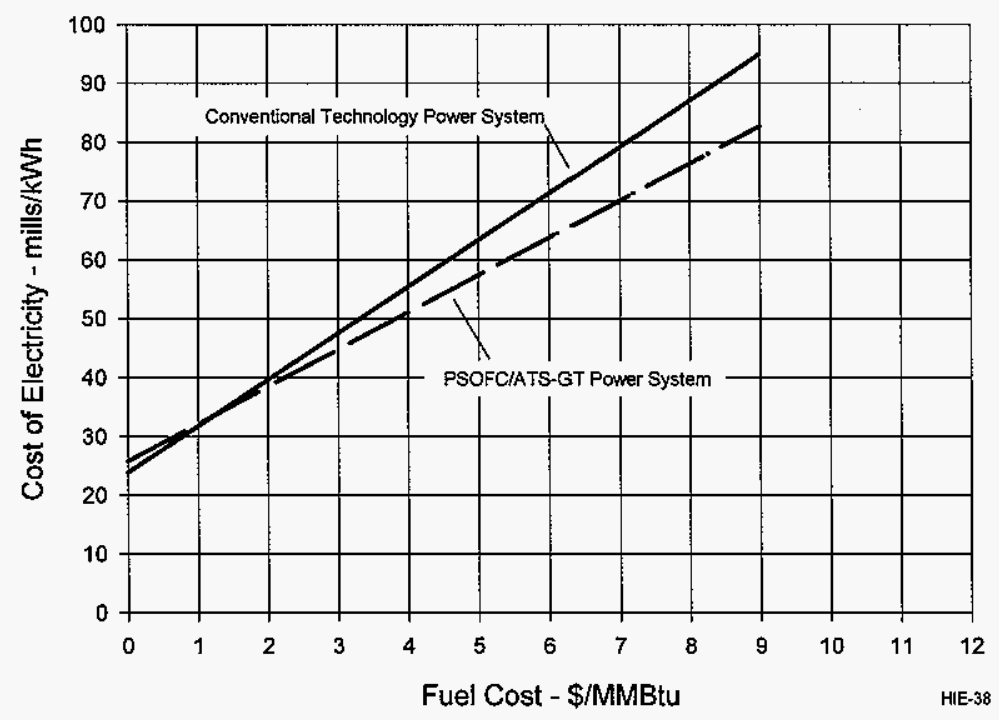

Figure 3-53 - Effect of fuel cost on COE estimates. 
Table 3.7 - Power System Installed-Cost Estimate*

\begin{tabular}{|c|c|c|c|c|c|c|}
\hline \multicolumn{7}{|c|}{ Installed Equipment Costs } \\
\hline & Equipment & Freight & Installation & Totals & & \\
\hline SOFC Generator & $8,183,259$ & 28,000 & 42,101 & $8,253,360$ & & \\
\hline Gas Turbine System & $4,900,000$ & 7,000 & 33,535 & $4,940,535$ & & \\
\hline $\begin{array}{l}\text { SOFC Power Conditioning Sys- } \\
\text { tem }\end{array}$ & $3,592,000$ & 10,500 & 21,666 & $3,624,166$ & & \\
\hline $\begin{array}{l}\text { Instrumentation, Controls, and } \\
\text { Electrical Cabinets }\end{array}$ & 873,542 & 7,000 & 199,520 & $1,080,062$ & & \\
\hline $\begin{array}{l}\text { Switchyard and Electrical Distri- } \\
\text { bution }\end{array}$ & $1,006,600$ & 7,000 & 244,524 & $1,258,124$ & & \\
\hline Fuel Supply System & 213,279 & 1,750 & 10,000 & 225,029 & & \\
\hline Hydrogen Supply System & 114,595 & 1,750 & 10,000 & 126,345 & & \\
\hline Purge Gas Supply System & 116,262 & 1,750 & 10,000 & 128,012 & & \\
\hline Auxiliary Air Supply System & 166,477 & 1,750 & 6,510 & 174,737 & & \\
\hline Startup Boiler System & 85,551 & 1,750 & 11,316 & 98,617 & & \\
\hline Piping and Insulation & $1,045,062$ & 14,000 & 197,690 & $1,256,752$ & & \\
\hline Site Buildings & & & & 36,159 & & \\
\hline Totals & $20,296,627$ & 82,250 & 786,862 & $21,201,898$ & & \\
\hline \multicolumn{7}{|c|}{ Project Cost Summary } \\
\hline Installed Equipment & & & & & & $\begin{array}{r}21,201,89 \\
8 \\
\end{array}$ \\
\hline $\begin{array}{l}\text { Project Management, Engi- } \\
\text { neering, Construction Indi- } \\
\text { rects, and Permitting } \\
\end{array}$ & & & & & & 922,469 \\
\hline Site Preparation & & & & & & 427,238 \\
\hline Grading, utilities installation & & & & & 146,072 & \\
\hline Foundations installation & & & & & 231,435 & \\
\hline Structural steel installation & & & & & 49,731 & \\
\hline $\begin{array}{l}\text { G\&A, R\&D, Sales \& Marketing, } \\
\text { Profit Allowance } \\
\end{array}$ & & & & & & $5,948,708$ \\
\hline Total Plant Cost & & & & & & $\begin{array}{r}28,500,31 \\
3 \\
\end{array}$ \\
\hline Spare Parts Allowance & & & & & & 257,631 \\
\hline Startup & & & & & & 150,000 \\
\hline Land & & & & & & 20,000 \\
\hline Total Capital Requirement & & & & & & $\begin{array}{r}28,927,94 \\
3 \\
\end{array}$ \\
\hline
\end{tabular}

* Site preparation and installation cost estimate provided by ICF Kaiser, Pittsburgh, PA under subcontract. 
Table 3.8 - Power System Cost of Electricity Estimate

\begin{tabular}{|c|c|c|c|}
\hline \multicolumn{2}{|l|}{ COE Calculation Basis } & \multicolumn{2}{|l|}{ Cost Summary } \\
\hline $\begin{array}{l}\text { No. round-the-clock power system } \\
\text { operators }\end{array}$ & 1 & & \\
\hline No. plants on system & 5 & Fixed O\&M, \$/kW-year & \\
\hline Operator labor cost, \$/man-hour & 75 & Plant operation \& control & 5.3 \\
\hline $\begin{array}{l}\text { Housekeeping maintenance, man- } \\
\text { hours/week/system }\end{array}$ & 20 & Housekeeping maintenance & 1.1 \\
\hline Housekeeping labor cost, $\$ /$ man-hour & 25 & $\begin{array}{l}\text { Administration ( } 30 \% \text { of operation } \\
\& \text { maintenance labor) }\end{array}$ & 1.9 \\
\hline System rating, MW net ac & 24.7 & Total Fixed O\&M, \$/kW-year & 8.3 \\
\hline Gas turbine rating, MW ac & 9.6 & Variable O\&M, mills/kWh & \\
\hline $\begin{array}{l}\text { Gas turbine maintenance cost, } \$ / G T \\
\text { kWh }\end{array}$ & 0.00377 & SOFC replacement & 1.4 \\
\hline $\begin{array}{l}\text { SOFC replacement cost, \$/SOFC } \\
\text { generator module }\end{array}$ & 468,920 & Gas turbine maintenance & 1.5 \\
\hline SOFC replacement interval, years & 10 & $\begin{array}{l}\text { Desulfurizer adsorbent/catalyst } \\
\text { replacement }\end{array}$ & 0.1 \\
\hline Power plant capacity factor & 0.92 & Total Variable O\&M, mills/kWh & 3.0 \\
\hline $\begin{array}{l}\text { Desulfurizer adsorbent \& catalyst, } \\
\$ / \text { year }\end{array}$ & 11,385 & & \\
\hline $\begin{array}{l}\text { Interest rate (SOFC replacement cost } \\
\text { calculation), \% }\end{array}$ & 6.0 & Total O\&M COE, mills/kWh & 4.0 \\
\hline $\begin{array}{l}\text { Power system efficiency (net } \\
\text { AC/LHV), \% }\end{array}$ & 59.87 & Capital COE, mills/kWh & 21.8 \\
\hline Capital charge rate, $\% /$ year & 15 & Fuel COE, mills/kWh & 19.0 \\
\hline Power system capital cost, $\$ / \mathrm{kW}$ & 1,172 & Total COE, mills/kWh & 44.8 \\
\hline Fuel Cost, $\$ / M M B t u$ & 3.0 & & \\
\hline Fuel higher heating value, Btu/lb & 21873 & & \\
\hline Fuel lower heating value, Btu/lb & 19711 & & \\
\hline
\end{tabular}


Table 3.9-Conventional-Technology Power System Cost of Electricity Estimate

Information Source: Gas Turbine World 1997 Handbook, p. 24

System Classification: Gas Turbine/Steam Turbine Combined Cycle

Gas Turbine: General Electric LM 1600

Steam Turbine Cycle: Two-pressure, $4.8 \mathrm{MWe}$

Net System Power Output: $17.9 \mathrm{MWe}$

System Efficiency: $47.9 \%$ (net AC/LHV)

Turnkey Price: $\$ 14.9 \mathrm{M}(\$ 830 / \mathrm{kWe})$

\begin{tabular}{|l|c|l|c|}
\multicolumn{1}{|c|}{ Basis } & & \multicolumn{1}{|c|}{ COE Summary } & \\
\hline No. round-the-clock power system operators & 1 & Fixed O\&M, \$/kW-year & \\
\hline No. plants on system & 5 & Plant operation \& control & 7.3 \\
\hline Operator labor cost, \$/man-hour & 75 & Housekeeping maintenance & 1.5 \\
\hline $\begin{array}{l}\text { Housekeeping maintenance, man- } \\
\text { hours/week/system }\end{array}$ & 20 & $\begin{array}{l}\text { Administration (30\% of opera- } \\
\text { tion \& maintenance labor) }\end{array}$ & 2.6 \\
\hline Housekeeping labor cost, \$/man-hour & 25 & Total & 11.4 \\
\hline Power system maintenance, \$/kWh & 0.007 & & \\
\hline Power system capacity factor & 0.92 & Variable O\&M, mills/kWh & 7.0 \\
\hline Power system capacity, net AC kWe & 17900 & & \\
\hline Power system efficiency (net AC/LHV), \% & 47.9 & Total O\&M COE, mills/kWh & 8.4 \\
\hline Capital charge rate, \%/year & 15 & & \\
\hline Power system capital cost, \$/kW & 830 & Capital COE, mills/kWh & 15.4 \\
\hline Fuel cost, \$/MMBtu (HHV) & 3.00 & & \\
\hline Fuel higher heating value, Btu/lb & 21873 & Fuel COE, mills/kWh & 23.7 \\
\hline Fuel lower heating value, Btu/lb & 19711 & Total & 47.6 \\
\hline
\end{tabular}




\subsection{Conceptual Design Trade-Off Studies}

\subsubsection{SOFC Generator Sizing}

\section{Introduction}

An analysis was performed to determine the number of cell substacks that should be included in the SOFC generator, which in turn is to be integrated with the Solar Turbines Mercury ${ }^{\top M} 50$ gas turbine in the PSOFC/ATS-GT hybrid power system. The analysis assumed that the engine would be operated at its design point, as established by the DOE Advanced Turbine Systems (ATS) program under which the Mercury ${ }^{\top M} 50$ gas turbine was developed. The analysis task, then, was to define the SOFC generator that would best utilize the Mercury ${ }^{T M} 50$ in the integration of the PSOFC and ATS-GT technologies.

The criterion used in specifying the SOFC generator was minimum COE. This particular conceptual design project was proposed on the premise that applying the powerintensive gas turbine in a PSOFC/GT hybrid cycle power system would minimize the number of relatively high-cost SOFC stacks required by the power system. Due largely to the need to fire the gas turbine, the system will not achieve the highest electric efficiency, but an attractively-low COE estimate could still result.

\section{Analysis Basis}

- Cycle configuration - Figure 3-54.

- Gas turbine - The gas turbine employed by the power system, as already indicated, is the Solar Turbines Mercury ${ }^{\mathrm{TM}} 50$ engine. The turbine was assumed to be operated at its design point, (combustor firing temperature $=2125^{\circ} \mathrm{F}$, compressor air intake rate $=36.5 \mathrm{lb} / \mathrm{s}$, pressure ratio $\sim 9.5: 1)$. It utilizes advanced gas turbine technology that was developed under the DOE ATS program.

- SOFC generator configuration - the generator is composed of pressurized generator modules. Each module is a horizontal pressure vessel housing twenty 576-cell substacks. (For reference, the EDB/ELSAM $100 \mathrm{~kW}$ SOFC generator includes the equivalent of two such substacks.) As Figure 3-54 indicates, the SOFC exhaust is the oxidant stream for the gas turbine combustor. In selecting the optimum number of cell substacks to be included in the power system, the number was varied systematically, and in each case, the cell current density was selected to establish an SOFC generator combustion zone exhaust temperature of $870^{\circ} \mathrm{C}$.

- The conventional SOFC stack configuration was assumed. 
- Air heater operation - The air heater shown in Figure 3-54 is assumed to operate only during system startup. It is not fired during normal steady-state power operations.

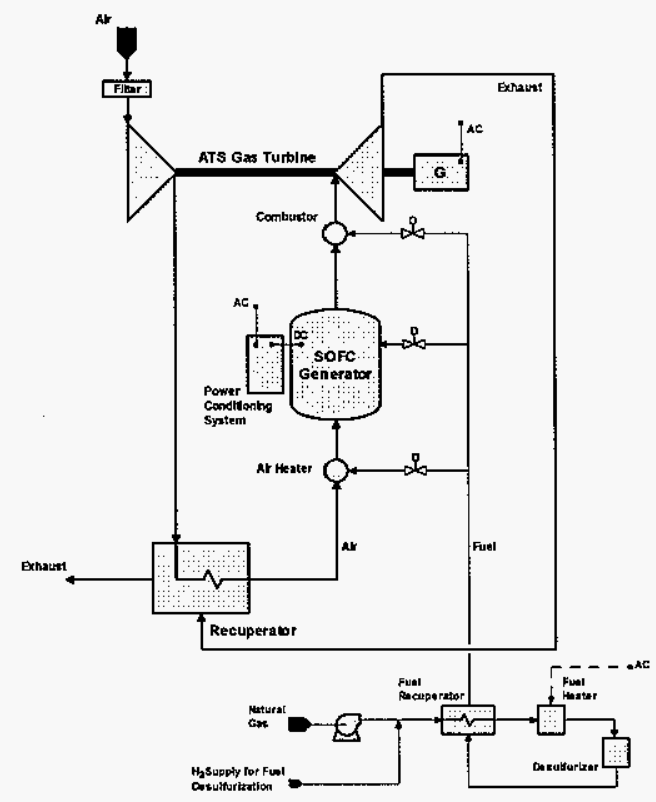

Figure 3-54 - Simplified PSOFC/ATS-GT hybrid power system cycle.

- Cell V-I characteristic - the mature-product characteristic.

- SOFC stoichs model - it was required that the SOFC stoichs specification conform as closely as possible to the stoichs profile determined by thermal-hydraulic analysis for $1020^{\circ} \mathrm{C}$ peak-cell and $870^{\circ} \mathrm{C}$ combustion-zone exhaust temperatures.

- SOFC fuel consumption $-85 \%$

- SOFC cell stack fuel bypass leakage - $1 \%$

- Power lead cooling air flow - 0

- Power lead and stack internals power loss - assumed $1 \%$ of cell power.

- SOFC power conditioning system overall efficiency -94\%, a representative value. (This study was performed before completion of the power conditioning conceptual design, wherein a PCS overall efficiency of approximately $95 \%$ was projected (Section 3.2.3.4). The optimum number of SOFC substacks was not affected.) 


\section{Discussion}

Results of the SOFC generator sizing study are graphed in Figure 3-55. The graph shows system electric efficiency and COE plotted against the system net AC power output. These results apply to a hybrid cycle power system consisting of an SOFC generator, composed of the indicated number of cell substacks, integrated with a single Mercury ${ }^{\top M} 50$ gas turbine. The estimated system efficiency increases with the number of cell stacks because the cell current density is able to move progressively to lower values at which the SOFC operating efficiency is higher. Initially, the system COE decreases in response to the addition of cell stacks, a direct result of the improving efficiency. However, the SOFC cost effect eventually becomes dominant, and the crossover between efficiency dominance and installed-cost dominance establishes the optimum number of SOFC substacks. The estimated minimum COE occurs with 72 substacks. However, 80 substacks were selected for power system design because it causes a very small COE increase relative to the minimum, but an efficiency gain of nearly $6 / 10$ of one percentage point is achieved. It is expected that the 80 substacks would be packaged in four horizontal cylindrical pressure vessels, 20 substacks per vessel.

A power block consisting of an SOFC generator composed of 80 cell substacks, and integrated with the Solar Turbines Mercury ${ }^{\top M} 50$ gas turbine, will generate $12.3 \mathrm{MWe}$ of net AC power at an efficiency of 59.5\% (net AC/LHV). Two blocks are needed for a 20 MWe-class power system. 


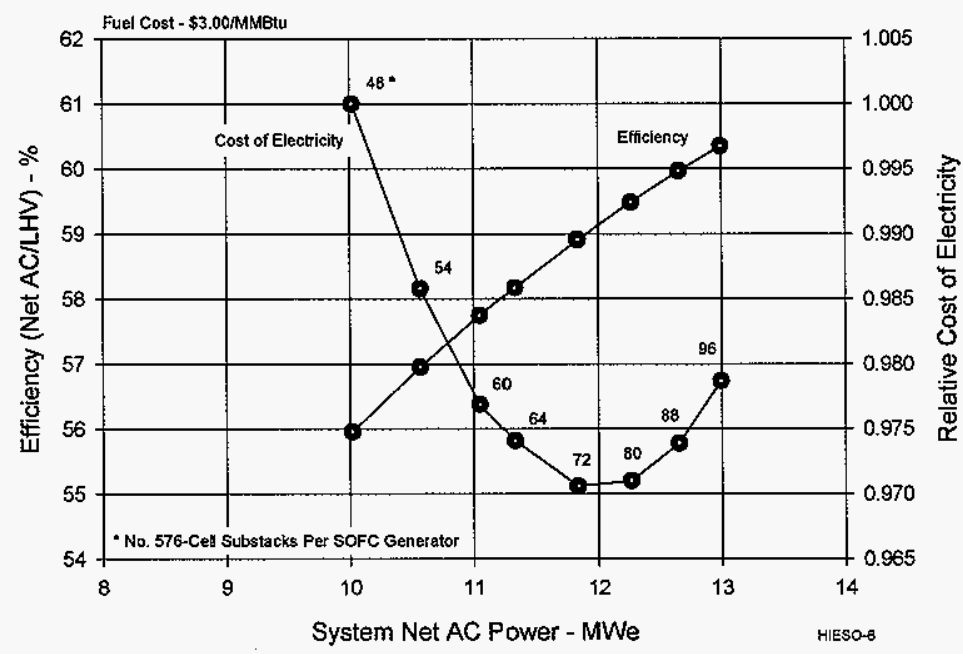

Figure 3-55 - Effect of PSOFC generator sizing on system performance and COE.

While an SOFC generator composed of 80 cell substacks will result in the minimum cost of electricity, it is recognized that the spread between the minimum and maximum COE values in Figure $3-55$ is not large, only $3 \%$. The advantage in designing with 80 cell substacks is that in addition to achieving the minimum COE value, a more attractive power system efficiency is also achieved. In addition, the cells are loaded less heavily at the minimum COE design point. At the 48 substack point, the cell current density is 400 $\mathrm{mA} / \mathrm{cm}^{2}$, while at the 80 substack point, it is less than $300 \mathrm{~mA} / \mathrm{cm}^{2}$.

\section{Conclusion}

The optimum (minimum COE) PSOFC/ATS-GT power system that employs a single, asdesigned Solar Turbines Mercury ${ }^{\top M} 50$ gas turbine will include an SOFC generator that consists of the equivalent of eighty 576-cell substacks. This system will generate 12.3 MWe (net AC) at an efficiency of $59.5 \%$ (net AC/LHV). Multiples of this system, or power block, could be arranged in parallel to achieve a desired total system power output.

\subsubsection{Steam Turbine Bottoming Cycle Option}

The reference PSOFC/ATS-GT power system discussed above is based on a hybridcycle power block in which a PSOFC generator is integrated with a Solar Turbines Mer- 
cury ${ }^{\mathrm{TM}} 50$ gas turbine. The exhaust gas at the recuperator exit, see Figure $3-7$, is still fairly hot, approximately $360^{\circ} \mathrm{C}$, and it could be applied to the generation of steam, which could be used in turn to drive a steam turbine/generator. Thus, as an alternative power system, one based on a PSOFC/ATS-GT/Steam Turbine (ST) cycle has been analyzed. Results are reviewed in this section. Note that in this work, only the effects of adding the steam turbine cycle to the baseline PSOFC/ATS-GT power system have been considered; the optimization of the PSOFC/ATS-GT part of the cycle was not re-visited.

Gas turbine steam injection is another potential use for the steam produced. This option has not been considered since the study approach was to apply the Mercury ${ }^{\mathrm{TM}} 50$ largely as it was developed by Solar Turbines during the DOE ATS program, as opposed to attempting any re-optimization of the engine (pressure ratio and TIT) for steam injection application.

\section{Discussion}

The cycle for the PSOFC/ATS-GT/ST power system is shown in Figure 3-56. The basic PSOFCIATS-GT cycle is unchanged from its configuration in the reference power system discussed earlier in the report, but a heat recovery system generator (HRSG) and steam turbine are added. The HRSG is a once-through unit, consisting of economizer, evaporator, and superheater sections. The evaporator generates steam at 31.0 bara (450 psia) for supply to the turbine with $28^{\circ} \mathrm{C}\left(50^{\circ} \mathrm{F}\right)$ of superheat. The deaerator operates on steam extracted from the steam turbine at 1.5 bara ( 22 psia), 0.14 bara ( 2 psi) above the deaerator pressure. The steam turbine was assumed to be a condensing unit, and the condenser operating pressure was set at 0.04 bara $(0.6 \mathrm{psia})$.

A summary of steam system design-point parameter values is provided in Table 3.10, and the estimated power system performance is summarized in Table 3.11. Note that the system considered was assumed to be composed of a single HRSG and steam turbine that operate on the combined exhaust from two PSOFC/ATS-GT power blocks. As defined above, each power block is composed of four PSOFC generator modules and a Mercury ${ }^{\top M} 50$ gas turbine. Relative to the reference hybrid power system, the addition of the steam turbine cycle increases the system power output by approximately 1.5 $\mathrm{MWe}$, and the system efficiency by nearly 4 percentage points. 


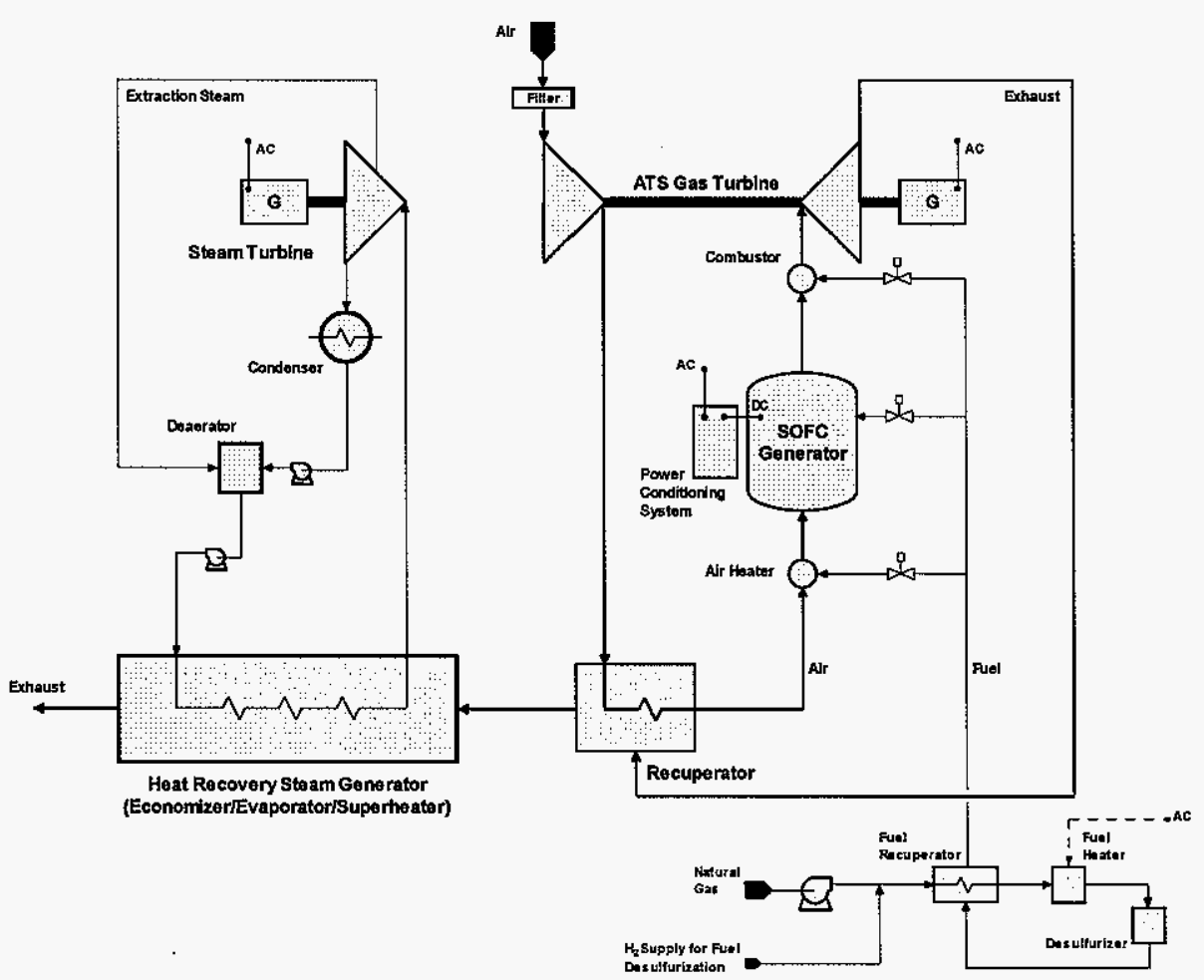

Figure 3-56 - PSOFC/ATS-GT/ST cycle.

Table 3.10

Steam Turbine System Design-Point Parameter Values

\begin{tabular}{|l|c|}
\hline \multicolumn{1}{|c|}{ Parameter } & \\
\hline Exhaust flow rate to HRSG & $33.9 \mathrm{~kg} / \mathrm{s}(74.6 \mathrm{lb} / \mathrm{s})$ \\
\hline Exhaust inlet temperature & $355 \mathrm{C}(670 \mathrm{~F})$ \\
\hline HP evaporator steam pressure & $31.0 \mathrm{bara}(450 \mathrm{psia})$ \\
\hline Superheated steam temperature & $264 \mathrm{C}(506 \mathrm{~F})$ \\
\hline Condenser pressure & $0.04 \mathrm{bara}(0.6 \mathrm{psia})$ \\
\hline Steam generation rate & $7,750 \mathrm{~kg} / \mathrm{h}(17,100 \mathrm{lb} / \mathrm{h})$ \\
\hline Makeup water flow rate & $195 \mathrm{~kg} / \mathrm{h}(430 \mathrm{bb} / \mathrm{h})$ \\
\hline Deaerator pressure & $1.38 \mathrm{bara}(20 \mathrm{psia})$ \\
\hline Steam turbine shaft power & $1.7 \mathrm{MW}$ \\
\hline Steam turbine/generator AC power & $1.6 \mathrm{MWe}$ \\
\hline Additional backpressure on GT exhaust due HRSG addition & $7 \mathrm{mbar}(0.1 \mathrm{psi})$ \\
\hline Evaporator pinch & $11 \mathrm{C}(20 \mathrm{~F})$ \\
\hline Exhaust exit temperature & $213 \mathrm{C}(420 \mathrm{~F})$ \\
\hline
\end{tabular}


Table 3.11

PSOFC/ATS-GT/ST Power System Design-Point Performance Estimates

\begin{tabular}{|l|c|}
\hline \multicolumn{1}{|c|}{ Parameter } & \\
\hline Compressor air intake rate & $33.1 \mathrm{~kg} / \mathrm{s}(72.9 \mathrm{lb} / \mathrm{s})$ \\
\hline Compressor pressure ratio & 9.5 \\
\hline Gas turbine combustor temperature & $1160 \mathrm{C}(2125 \mathrm{~F})$ \\
\hline SOFC gross AC power & $15.9 \mathrm{MWe}$ \\
\hline Gas turbine gross AC power & $9.6 \mathrm{MWe}$ \\
\hline Steam turbine gross AC power & $1.6 \mathrm{MWe}$ \\
\hline Steam turbine cycle efficiency (net steam cycle AC/cycle heat input) & $29.7 \%$ \\
\hline Auxiliary power requirement & $0.8 \mathrm{MWe}$ \\
\hline System net AC power & $26.2 \mathrm{MWe}$ \\
\hline Efficiency (net AC/LHV) & $63.6 \%$ \\
\hline Carbon dioxide emission & $317 \mathrm{~kg} / \mathrm{MWh}$ \\
\hline Nitrogen oxide emission (based on 5 ppmv addition at the gas turbine combustor) & $.038 \mathrm{~kg} / \mathrm{MWh}$ \\
\hline Sulfur dioxide emission & 0 \\
\hline
\end{tabular}

\subsubsection{Power System Cost and Cost-of-Electricity Evaluation}

The power system installed-cost estimate, including the HRSG and steam turbine, is presented in Table 3.12. The equipment and installation costs for the steam turbine cycle equipment were obtained through contact with potential suppliers. Table 3.13 provides the power system COE development. The estimated COE for the system equipped with the steam turbine cycle is 49 mills/kWh, over 4 mills higher than the COE estimate for the baseline PSOFC/ATS-GT power system (see Table 3.8). An important factor in the COE estimate is the steam-system operator basis (number of operators and pay rate). As Table 3.13 indicates, this particular calculation assumed that one roundthe-clock on-site steam system operator would be required, in addition to the power system operator who monitors/controls several power systems from a remote location.

COE vs fuel cost estimates are graphed in Figure 3-57 for the PSOFC/ATS-GT/ST power system, and the estimates for the conventional-technology and PSOFC/ATS-GT power systems are repeated from Figure 3-53. The curves indicate that the PSOFC/ATS-GT/ST power system, with a steam system operator, would have no COE advantage relative to the baseline PSOFC/ATS-GT power system, and advantage relative to the conventionaltechnology system only at moderate to high fuel costs. However, if the system design, by exploiting factors such as the boiler type, size, volume, etc, could do without the steam operator, it would reduce the PSOFC/ATS-GT/ST COE estimates by approximately 4 mills over the entire fuel cost range. This would make it clearly competitive 
with the conventional-technology system, regardless of fuel cost, but there would still be no clear COE advantage relative to the baseline PSOFC/ATS-GT system. This result indicates that the positive COE effect of the additional power output and higher efficiency produced by the addition of the steam turbine cycle is largely canceled by higher installation and $O \& M$ costs.

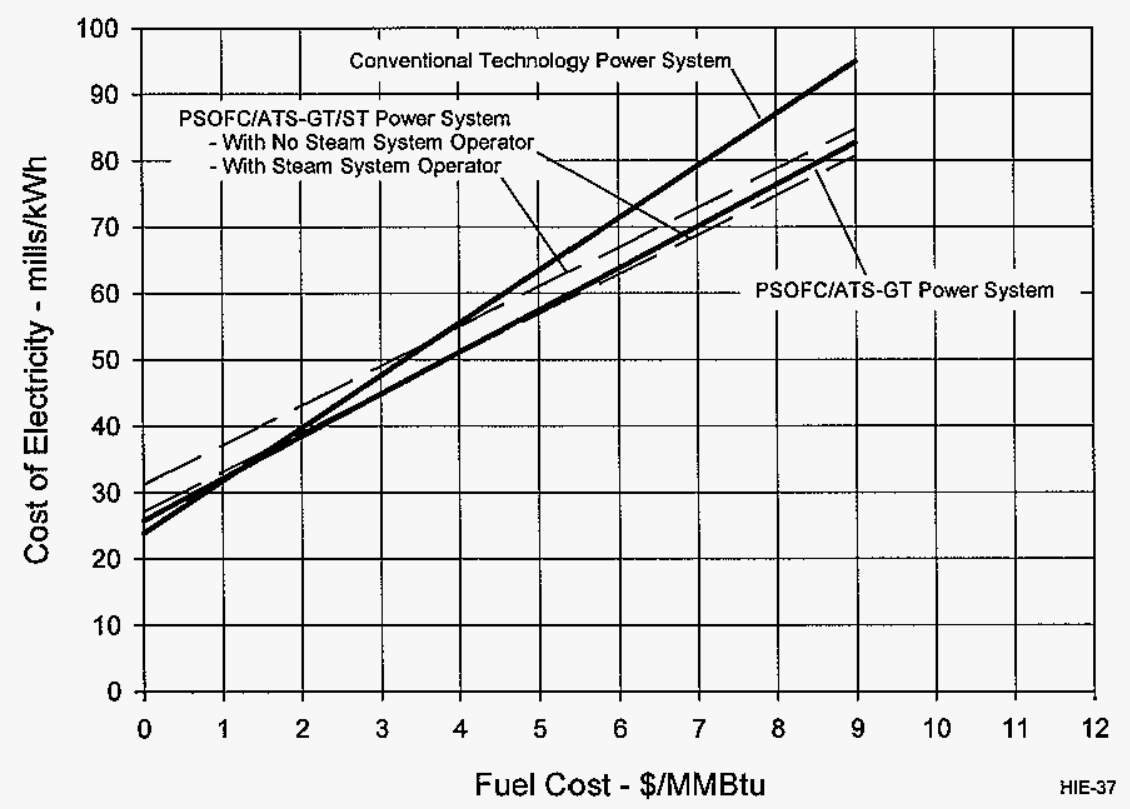

Figure 3-57 - COE estimates for the PSOFC/ATS-GT/ST power system. 
Table 3.12

Power System Installed-Cost Estimate (PSOFC/ATS-GT/ST Power System)

\begin{tabular}{|c|c|c|c|c|c|c|}
\hline Installed Equipment Costs & Equipment & Freight & Installation & Totals & & \\
\hline SOFC Generator & $8,183,259$ & 28,000 & 42,101 & $8,253,360$ & & \\
\hline Gas Turbine System & $4,900,000$ & 7,000 & 33,535 & $4,940,535$ & & \\
\hline SOFC Power Conditioning System & $3,592,000$ & 10,500 & 21,666 & $3,624,166$ & & \\
\hline Instrumentation, Controls, and Electrical Cabinets & 873,542 & 7,000 & 199,520 & $1,080,062$ & & \\
\hline HRSG, Feed \& Condensate System & 276,900 & 7,000 & 138,500 & 422,400 & & \\
\hline Steam Turbine & $1,700,000$ & 3,500 & 138,500 & $1,842,000$ & & \\
\hline Switchyard and Electrical Distribution & $1,006,600$ & 7,000 & 244,524 & $1,258,124$ & & \\
\hline Fuel Supply System & 212,952 & 1,750 & 10,000 & 224,702 & & \\
\hline Hydrogen Supply System & 114,420 & 1,750 & 10,000 & 126,170 & & \\
\hline Purge Gas Supply System & 116,262 & 1,750 & 10,000 & 128,012 & & \\
\hline Auxiliary Air Supply System & 166,477 & 1,750 & 6,510 & 174,737 & & \\
\hline Startup Boiler System & 85,551 & 1,750 & 11,316 & 98,617 & & \\
\hline Piping and Insulation & $1,045,062$ & 14,000 & 197,690 & $1,256,752$ & & \\
\hline Site Buildings & & & & 36,159 & & \\
\hline Totals & $22,273,024$ & 92,750 & $1,063,862$ & $23,465,795$ & & \\
\hline & & & & & & \\
\hline \multicolumn{7}{|l|}{ Project Cost Summary } \\
\hline Installed Equipment & & & & & & $23,465,795$ \\
\hline $\begin{array}{l}\text { Project Management, Engineering, Construc- } \\
\text { tion Indirects, and Permitting }\end{array}$ & & & & & & 922,469 \\
\hline Site Preparation & & & & & & 427,238 \\
\hline Grading, utilities installation & & & & & 146,072 & \\
\hline Foundations installation & & & & & 231,435 & \\
\hline Structural steel installation & & & & & 49,731 & \\
\hline G\&A, R\&D, Sales \& Marketing, Profit Allowance & & & & & & $6,541,627$ \\
\hline Total Plant Cost & & & & & & $31,357,130$ \\
\hline Spare Parts Allowance & & & & & & 455,270 \\
\hline Startup & & & & & & 150,000 \\
\hline Land & & & & & & 20,000 \\
\hline Total Capital Requ & & & & & & $31,982,400$ \\
\hline
\end{tabular}


Table 3.13

Power System Cost of Electricity Estimate

(PSOFC/ATS-GT/ST Power System)

\begin{tabular}{|c|c|c|c|}
\hline COE Calculation Basis & & COE Summary & \\
\hline No. round-the-clock power system operators & 1 & Fixed O\&M, \$/kW-year & \\
\hline No. plants on system & 5 & & \\
\hline $\begin{array}{l}\text { No. round-the-clock steam system operators per } \\
\text { power system }\end{array}$ & 1 & & \\
\hline Operator labor cost, \$/man-hour & 75 & Plant operation \& control & 30.1 \\
\hline $\begin{array}{l}\text { Housekeeping maintenance, man- } \\
\text { hours/week/system }\end{array}$ & 20 & Housekeeping maintenance & 1.0 \\
\hline Housekeeping labor cost, \$/man-hour & 25 & Administration ( $30 \%$ of operation \& maintenance labor) & 9.3 \\
\hline System rating, MW net ac & 26.2 & Total Fixed O\&M, \$/kW-year & 40.5 \\
\hline Gas turbine rating, MW ac & 9.6 & & \\
\hline Steam furbine rating, MW ac & 1.6 & Variable O\&M, mills/kWh & \\
\hline HRSG, steam turbine maintenance cost, $\$ / \mathrm{kWh}$ & 0.0106 & & \\
\hline Gas turbine maintenance cost, $\$ / k W h$ & 0.00377 & SOFC replacement & 1.3 \\
\hline SOFC replacement cost, \$/SOFC generator module & 468,920 & HRSG, steam turbine system maintenance & 0.6 \\
\hline SOFC replacement interval, years & 10 & Gas turbine maintenance & 1.4 \\
\hline Power plant capacity factor & 0.92 & Desulfurizer adsorbent/catalyst replacement & 0.1 \\
\hline Desulfurizer adsorbent \& catalyst, \$/year & 11,367 & Total Variable O\&M, mills/kWh & 3.3 \\
\hline $\begin{array}{l}\text { Interest rate (SOFC replacement cost calculation), } \\
\%\end{array}$ & 6.0 & & \\
\hline Power system efficiency (net AC/LHV), \% & 63,634 & Total O\&M COE, mills/kWh & 8.4 \\
\hline & & Capital COE, mills/kWh & 22.7 \\
\hline Capital charge rate, \%/year & 15 & Fuel COE, mills/kWh & 17.9 \\
\hline Power system capital cost, \$/kW & 1,222 & Total COE, mills/kWh & 49.0 \\
\hline Fuel Cost, \$/MMBtu & 3.0 & & \\
\hline Fuel higher heating value, Btu/lb & 21873 & & \\
\hline Fuel lower heating value, Btu/lb & 19711 & & \\
\hline
\end{tabular}

\subsubsection{Advanced Ammonia-Water Power Cycle for the PSOFC/GT Hybrid System}

The ammonia-water power system concept and the material presented in report Sections 3.4.3.1 to 3.4.3.4 were developed by Energy Concepts Company, Annapolis, MD.

\subsubsection{Introduction}

This section presents the results of an analysis of an ammonia-water absorption power cycle, which is adapted to be powered by the $360^{\circ} \mathrm{C}$ exhaust gas from the $20 \mathrm{MWe}$ class PSOFCIATS-GT power plant. The ammonia-water power cycle is found to provide an additional $1.9 \mathrm{MWe}$ from the waste heat - more than is possible with other wasteheat powered cycles. 
This conceptual analysis consists of a description of the cycle; design heat and mass balance; indication of system size and footprint; and estimation of the installed cost and the operation and maintenance cost. This study is limited to consideration of this cycle exclusively in the stand-alone bottoming cycle role. Note that in this work, only the effects of adding the ammonia-water power cycle to the baseline PSOFC/ATS-GT power system have been considered; the optimization of the PSOFC/ATS-GT part of the cycle was not re-visited.

\subsubsection{Background}

Ammonia-water power cycles have been known for at least fifty years. Vapor phase ammonia is generated from the water absorbent at high pressure, expanded to produce work, and then absorbed at low pressure. The three recognized attributes of the ammonia-water power cycles are: they excel with low-temperature heat $\left(<350^{\circ} \mathrm{C}\right)$; the temperature glide of the vapor-generation process allows a close match to that of the heat source; and the high pressures allow the use of compact and inexpensive equipment. However, heretofore, various deficiencies have prevented their wide application. Prior-art absorption power cycles have been limited in the degree to which they can match heat-source temperature glide, thus limiting their useful work production and ability to provide high energy-conversion efficiency. The simple, traditional cycle provides only about a $20 \%$ advantage over the Rankine cycle. More efficient cycles, with a high level of recuperation of internal heat, can provide up to $70 \%$ improvement over the Rankine cycle, but they are more complex, and many of them involve a problematic total evaporation of the fluid mixture at high temperature. Energy Concepts $\mathrm{Co}$. has been pursuing the development of highly integrated ammonia-water absorption refrigeration cycles [1,2] and power cycles [3] that avoid the technical risk and much of the complexity of the prior cycles. With the newly developed improved power cycle and ongoing component development, large amounts of waste heat in the temperature range of $100^{\circ} \mathrm{C}$ to $350^{\circ} \mathrm{C}$ can be economically converted to useful power, rather than discharged into the environment.

Historically low energy costs have inhibited technology that provides energy-efficiency improvements. There was not enough economic incentive to develop and adopt such technologies. However, the economic and environmental factors are changing; energy costs are increasing and there is rising concern over the $\mathrm{CO}_{2}$ emissions associated with 
inefficient power cycles. The advanced ammonia-water power cycle provides the one missing ingredient for the realization of hybrid fuel-cell power cycles with high energyconversion efficiency.

\subsubsection{Ammonia-Water Power Cycle}

The ammonia-water power cycle is applied as the bottoming cycle on the $20 \mathrm{MWe}$-class PSOFCIATS-GT hybrid system. The exhaust gas exiting the system recuperator is used as the heat source for the ammonia-water power cycle. Temperature and mass flow rates of the exhaust gas are $360^{\circ} \mathrm{C}$ and $121,900 \mathrm{~kg} / \mathrm{hr}$, the combined exhaust from two PSOFC/ATS-GT power blocks. The composition of the exhaust stream is: $\mathrm{N}_{2} 74.6 \%$, $\mathrm{H}_{2} \mathrm{O} 9.6 \%, \mathrm{CO}_{2} 4.7 \%$, and $\mathrm{O}_{2} 11.2 \%$.

Relative to the ammonia-water power cycle, the basic assumptions for the conceptual design are:

1. Turbine and generator efficiencies are $85 \%$ and $95 \%$, respectively.

2. Cooling media is water; either from cooling tower or natural sources.

3. The material of construction for the heat/mass transfer units and piping is carbon steel, and an appropriate corrosion inhibitor is used.

4. Pressure losses in transfer lines and components are not considered for the cycle analysis at this stage.

Power Cycle Description. The power cycle, shown in Figure 3-58, consists of a heatrecovery unit, thermal generator, internal recuperator, ammonia absorber, and turbine plus electric generator. The system requires three solution pumps, one transfer-fluid pump, and a cooling-water pump. Only one solution pump is shown in Figure 3-58, the other two are integrated in the recuperator. For better control and integration of the power cycle, a closed flow loop with water as transfer fluid is used for heat recovery. This approach maintains low pressure drop on the exhaust gas side and thereby minimizes the backpressure for the gas turbine. About $90 \%$ of the heat from the transfer fluid is used for generating vapor in the thermal generator. The counter-current heat and mass transfer processes in the thermal generator facilitate an efficient heat extraction from the transfer fluid. The remaining heat is used in the recuperator, which is an 


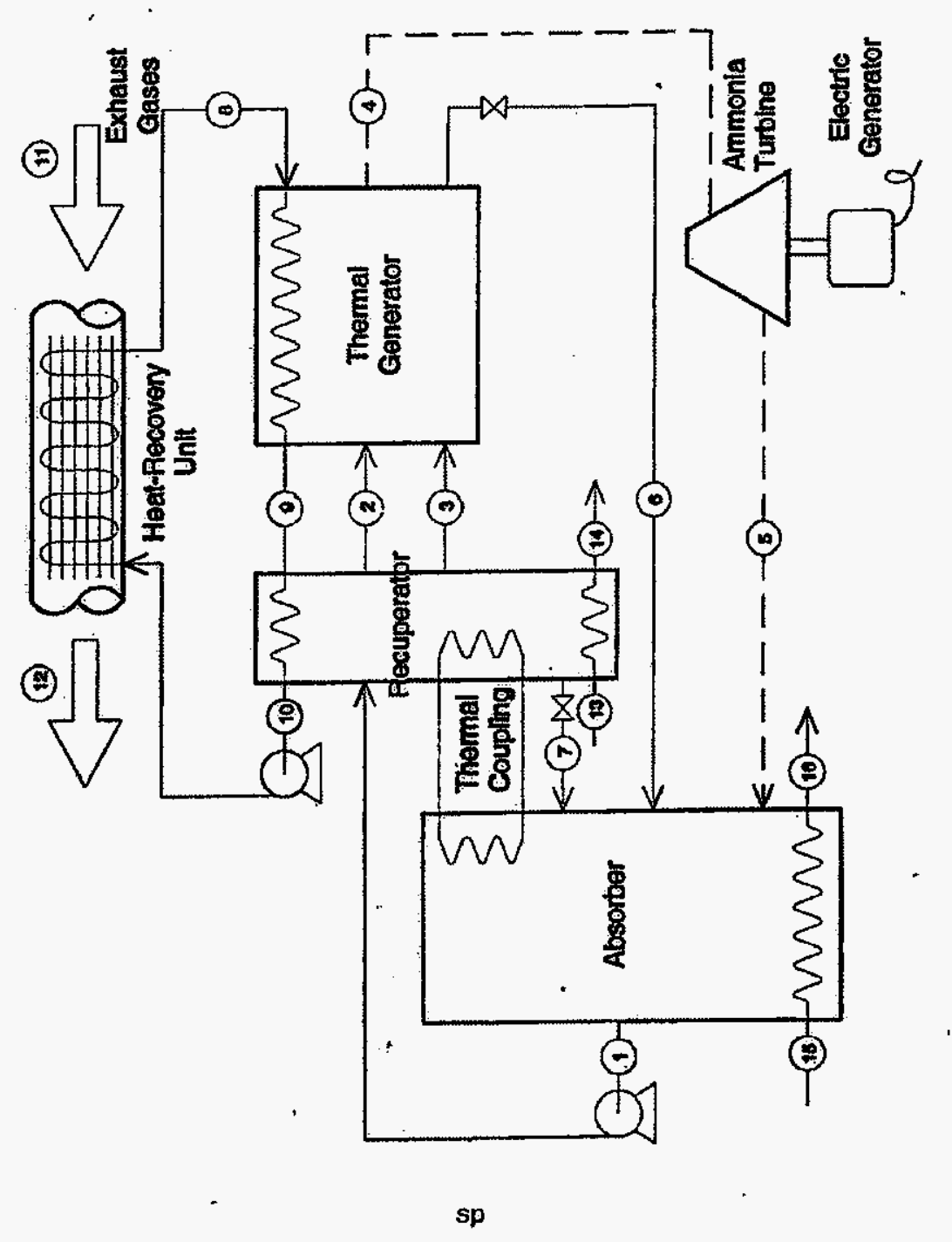

造 
integrated heat and mass transfer unit for recuperating internal and external heats. Ammonia vapor in the generator is internally superheated. The vapor then drives the turbine and the resulting low-pressure ammonia vapor flows to the absorber, where it is absorbed in the strong (high absorbing capacity) solution from the generator. The resulting weak (low absorbing capacity) solution is pumped to the recuperator, where it is divided into three streams for balancing the heat and mass transfer from different sections of the recuperator. As shown in Figure 3-58, one stream from the recuperator returns to the absorber, and also the recuperator and absorber are thermally coupled. Heat integration in the recuperator is a key design feature of the power cycle, because the overall conversion efficiency of the cycle depends on the thermal performance of the recuperator.

Heat flows in the major components are summarized in Table 3.14. The total thermal energy recovered from the exhaust gas stream is $10,305 \mathrm{kWth}$, which is $77.3 \%$ of the residual LHV of the exhaust gas. Of this, about $20 \%$ is converted to electric power. A simple Rankine cycle would convert only $12 \%$ of the heat recovered from the exhaustgas stream. After accounting for pumping losses, the net energy produced by the ammonia-water cycle is $1,907 \mathrm{kWe}$. The recuperator recovers a significant part of the heat of absorption. The remaining heat of absorption is rejected to cooling water at inlet temperature of $21.1^{\circ} \mathrm{C} ; 5,129 \mathrm{~kW}$ th from the absorber and $3,095 \mathrm{~kW}$ th from the recuperator. 
Table 3.14 - Energy Flows in the Ammonia-Water Power Cycle

\begin{tabular}{|l|c|c|}
\hline \multicolumn{1}{|c|}{ Components } & $\begin{array}{c}\text { Heat Rate } \\
\mathbf{k W}\end{array}$ & $\begin{array}{c}\text { Power Generation } \\
\mathbf{k W}\end{array}$ \\
\hline Heat recovery unit & 10,305 & \\
\hline Generator - heat from transfer fluid & 9,224 & \\
\hline Recuperator & & \\
$\quad$ Heat from transfer fluid & 1,081 & \\
$\quad$ Heat rejected to water & 3,095 & \\
\hline Absorber - heat rejected to water & 5,129 & \\
\hline Turbine power & & 2,081 \\
\hline Electric generator power & & 1977 \\
\hline Pumping power & & 70 \\
\hline Net power & & 1,907 \\
\hline
\end{tabular}

Cycle Parameters. A cycle-analysis model was used to determine the optimized design parameters of the cycle. The model calculates the thermodynamic state points of the cycle, the overall heat and mass balance, and heat and mass transfer rates for each component. Table 3.15 presents the thermodynamic properties and mass flow rates at the state points identified in Figure 3-58. The exhaust gas is cooled from $360^{\circ} \mathrm{C}$ to $93.8^{\circ} \mathrm{C}$, by heating the transfer fluid from $76.7^{\circ} \mathrm{C}$ to $243.3^{\circ} \mathrm{C}$. The transfer fluid is maintained at a pressure of 40 bar to prevent boiling. Ammonia vapor is generated at a pressure of 32 bar and superheated to $234.2^{\circ} \mathrm{C}$, with ammonia concentration of $92 \%$ by weight. The outlet conditions from the turbine are: pressure, 2.05 bar; temperature, $50.7^{\circ} \mathrm{C}$; and vapor quality, 0.94 . The integrated system of recuperator and absorber provides this relatively low ammonia-absorption pressure, which is responsible for the high energy-conversion efficiency. Ammonia vapor from the turbine and the strong solution from the thermal generator at $103.9^{\circ} \mathrm{C}$ flow to the absorber. The weak solution at 29.4 ${ }^{\circ} \mathrm{C}$ is pumped to the recuperator. Two solution streams from the recuperator at $93^{\circ} \mathrm{C}$ and concentrations of $26 \%$ and $65 \%$ return to the thermal generator to complete the cycle. 
Table 3.15 - State Points for the Ammonia-Water Power Cycle

\begin{tabular}{|c|c|c|r|r|c|}
\hline $\begin{array}{c}\text { State } \\
\text { Point }\end{array}$ & $\begin{array}{c}\text { Temperature } \\
{ }^{\circ} \mathbf{C}\end{array}$ & Pressure Bar & $\begin{array}{c}\text { Flow Rate } \\
\mathbf{k g} / \mathbf{s}\end{array}$ & $\begin{array}{c}\text { Enthalpy } \\
\mathbf{k J / k g}\end{array}$ & $\begin{array}{c}\text { Concentration } \\
\text { weight fraction }\end{array}$ \\
\hline 1 & 29.4 & 2.05 & 13.3 & 25 & 0.29 \\
\hline 2 & 93.5 & & 6.3 & 312 & 0.26 \\
\hline 3 & 93.9 & & 4.5 & 453 & 0.65 \\
\hline 4 & 234.2 & 32.0 & 4.9 & 2183 & 0.92 \\
\hline 5 & 50.7 & 2.05 & 4.9 & 1683 & 0.92 \\
\hline 6 & 103.9 & 2.05 & 5.9 & 430 & 0.01 \\
\hline 7 & 76.0 & 2.05 & 2.5 & 232 & 0.26 \\
\hline 8 & 243.3 & 40.0 & 14.9 & & \\
\hline 9 & 94.2 & & 14.9 & & \\
\hline 10 & 76.7 & & 14.9 & & \\
\hline 11 & 360.0 & $\sim 1$ & 33.8 & & \\
\hline 12 & 93.8 & $\sim 1$ & 33.8 & & \\
\hline 13 & 21.1 & & 40.6 & & \\
\hline 14 & 39.4 & & 40.6 & & \\
\hline 15 & 21.1 & & 64.7 & & \\
\hline 16 & 40.2 & & 64.7 & & \\
\hline
\end{tabular}

System Dimensions and Interfacing. Components of the ammonia-water power cycle are assembled into three major subsections and installed as skid-mounted units. Their approximate dimensions are as follows. The absorber and associated components are assembled on a horizontal skid with a footprint of $3 \times 10 \mathrm{~m}$, and height of $3.4 \mathrm{~m}$. The generator and recuperator are installed on a vertical skid with a footprint of $3 \times 3 \mathrm{~m}$, and height of $8 \mathrm{~m}$. The ammonia turbine/generator set and the heat-recovery unit are installed in a skid with the same dimensions as the absorber skid, and can be mounted either alongside or on the top of the absorber skid, depending on plot space availability. When adequate supply of cooling water is not available at the site, a fourth skid is required for the cooling system. It is expected that with appropriate equipment rearrangement to facilitate the consolidation of exhaust gas flows from the two PSOFC/ATSGT power blocks (see Figure 3-8), the footprint projected by the $20 \mathrm{MWe-class}$ PSOFC/ATS-GT, including the ammonia-water power cycle equipment, would still be approximately 0.6 acre. 
The major interfacing requirements include electric power line, cooling water, exhaustgas supply line, instrument air, and sensor cables. An onboard-control and dataacquisition system monitors performance and can provide some local control capability. Main control and monitoring of the ammonia-water power cycle is performed from the central control room provided for the PSOFC/ATS-GT hybrid system.

\subsubsection{Economics}

Installed Cost. Table 3.16 presents the estimated installed cost for the ammonia-water power cycle. Two cost estimates are presented - one for near-term fabrication of a single unit, and the other for serial fabrication of 10 to 100 units per year in the year 2010 . In the latter case, many economic benefits are achieved: volume procurement; improving component technology as field experience is gained; standard engineering-design package availability; and serial production and assembly infrastructure - jigs, fixturing, etc. Overall, the cost declines from $\$ 3,880 / \mathrm{kWe}$ for the one-of-a-kind project to $\$ 1,550 / \mathrm{kWe}$ for the serially produced product.

Table 3.16 - Installed Cost for the Ammonia-Water Power Cycle

\begin{tabular}{|c|c|c|c|}
\hline & $\begin{array}{c}\text { Present Cost } \\
\text { (Single Unit) } \\
\mathbf{\$}\end{array}$ & $\begin{array}{c}\text { Mature Technology } \\
\text { Cost (2010) } \\
\mathbf{\$}\end{array}$ & $\begin{array}{c}\text { Cost Reduction } \\
\text { Factors* }\end{array}$ \\
\hline Components & 225,000 & 86,540 & 2.6 \\
\hline Thermal generator & 125,000 & 48,080 & 2.6 \\
\hline Recuperator & 250,000 & 96,150 & 2.6 \\
\hline Absorber & 800,000 & 307,690 & 1.6 \\
\hline Ammonia turbine & 300,000 & 187,500 & 1.6 \\
\hline Heat-recovery unit & 100,000 & 62,500 & 1.6 \\
\hline Pumps plus controllers & 50,000 & 31,250 & \\
\hline Control and sensors & $1,850,000$ & 819,710 & \\
\hline Subtotal & $5,550,000$ & $2,134,610$ & \\
\hline Assembly and Installation & $7,400,000$ & $2,954,320$ & \\
\hline Installed Cost & 3,880 & 1,550 & \\
\hline Cost/kWe & & & \\
\hline
\end{tabular}

* Factor 2.6 for technology development and volume production Factor 1.6 for volume production 
The costs for components unique to the power cycle /thermal generator, recuperator, and absorber) are based upon Energy Concepts experience in fabricating and procuring similar components, albeit sizes at only about $15 \%$ of the scale required here. Standard scale factors are applied to extrapolate to larger sizes. The remaining items are off-theshelf components, and cost estimates are derived from vendor quotes for similar items.

Operation and Maintenance (O\&M) Cost. Since the system uses waste heat, there is no fuel component of the operating cost. The primary cost is the pump power, which has already been factored in to calculation of the net power production. The system is designed to operate unattended, with displays and key controls in the central control room. Hence, no additional operating staff is required for the ammonia-water power cycle, beyond the operator already present in the control room. One person will be required for startups, scheduled shutdowns, and routine maintenance. The routine maintenance labor is estimated at 8 man-hours per week. The overall maintenance requirement is dominated by the ammonia turbine, followed by cooling tower and pumps. The annual total maintenance cost is estimated at $\$ 75,000$, plus an allowance for periodic major overhaul of the ammonia turbine.

\subsubsection{PSOFC/ATS-GT/Ammonia-Water Power System Performance Estimates}

Performance estimates for the PSOFC/ATS-GT/Ammonia-Water power system are summarized in Table 3.17 .

Table 3.17

PSOFC/ATS-GT/Ammonia-Water Power System Design-Point Performance Estimates

\begin{tabular}{|l|c|}
\hline \multicolumn{1}{|c|}{ Parameter } & \\
\hline Compressor pressure ratio & 9.5 \\
\hline Compressor air intake rate & $33.1 \mathrm{~kg} / \mathrm{s}(72.9 \mathrm{lb} / \mathrm{s})$ \\
\hline Gas turbine combustor temperature & $1160 \mathrm{C}(2125 \mathrm{~F})$ \\
\hline SOFC gross AC power & $15.9 \mathrm{MWe}$ \\
\hline Gas turbine gross AC power & $9.6 \mathrm{MWe}$ \\
\hline Ammonia-water power system gross AC power & $1.9 \mathrm{MWe}$ \\
\hline Auxiliary power requirement & $0.8 \mathrm{MWe}$ \\
\hline System net AC power & $26.5 \mathrm{MWe}$ \\
\hline Efficiency (net AC/LHV) & $64.4 \%$ \\
\hline Carbon dioxide emission & $313 \mathrm{~kg} / \mathrm{MWh}$ \\
\hline $\begin{array}{l}\text { Nitrogen oxide emission (based on } 5 \mathrm{ppmv} \text { addi- } \\
\text { tion at the gas turbine combustor) }\end{array}$ & $0.038 \mathrm{~kg} / \mathrm{MWh}$ \\
\hline Sulfur dioxide emission & 0 \\
\hline
\end{tabular}




\subsubsection{Power System Cost and Cost-of-Electricity Evaluation}

An installed-cost estimate for the PSOFC/ATS-GT/Ammonia-Water power system is presented in Table 3.18. It was developed integrating estimates generated by Siemens Westinghouse and Caterpillar/Solar Turbines for the PSOFC/ATS-GT power system with the ammonia-water system costs developed by Energy Concepts Company and discussed above. The development of a COE estimate for the system is presented in Table 3.19. The ammonia-water system $O \& M$ cost was calculated using the $\$ 75,000$ annual maintenance estimated by Energy Concepts plus an assumed annual sinking-fund allowance that would accumulate $\$ 500,000$ in five years for a major overhaul of ammonia-water power system equipment. Viewing the systems as being similar in O\&M complexity, it is noted that the resulting O\&M cost, $\$ 0.0106 / \mathrm{kWh}$, was also applied in evaluating the COE for the PSOFC/ATS-GT/ST power system (see Table 3.13).

COE estimates for the PSOFC/ATS-GT/Ammonia-Water power system, in addition to those for the conventional-technology and the baseline PSOFC/ATS-GT systems are graphed in Figure 3-59. As in the analysis of the PSOFC/ATS-GT/ST power system, the PSOFC/ATS-GT/Ammonia-Water and baseline PSOFC/ATS-GT power systems are found to have similar COE performance projections, with the effect of additional power generation and efficiency produced by installing the ammonia-water power system being largely offset by higher installation and $O \& M$ costs. 
Table 3.18

Power System Installed-Cost Estimate (PSOFC/ATS-GT/Ammonia-Water Power System)

\begin{tabular}{|c|c|c|c|c|c|c|}
\hline \multicolumn{7}{|c|}{ Installed Equipment Costs } \\
\hline & Equipment & Freight & Installation & Totals & & \\
\hline SOFC Generator & $8,183,259$ & 28,000 & 42,101 & $8,253,360$ & & \\
\hline Gas Turbine System & $4,900,000$ & 7,000 & 33,535 & $4,940,535$ & & \\
\hline SOFC Power Conditioning System & $3,592,000$ & 10,500 & 21,666 & $3,624,166$ & & \\
\hline $\begin{array}{l}\text { Instrumentation, Controls, and Elec- } \\
\text { trical Cabinets }\end{array}$ & 873,542 & 7,000 & 199,520 & $1,080,062$ & & \\
\hline Ammonia-Water Power System & $2,956,000$ & 10,500 & 277,000 & $3,243,500$ & & \\
\hline Switchyard and Electrical Distribution & $1,006,600$ & 7,000 & 244,524 & $1,258,124$ & & \\
\hline Fuel Supply System & 212,954 & 1,750 & 10,000 & 224,704 & & \\
\hline Hydrogen Supply System & 114,421 & 1.750 & 10,000 & 126,171 & & \\
\hline Purge Gas Supply System & 116,262 & 1,750 & 10,000 & 128,012 & & \\
\hline Auxiliary Air Supply System & 166,477 & 1,750 & 6,510 & 174,737 & & \\
\hline Startup Boiler System & 85,551 & 1,750 & 11,316 & 98,617 & & \\
\hline Piping and Insulation & $1,045,062$ & 14,000 & 197,690 & $1,256,752$ & & \\
\hline Site Buildings & & & & 36,159 & & \\
\hline Totals & $23,252,127$ & 92,750 & $1,063,862$ & $24,444,898$ & & \\
\hline \multicolumn{7}{|c|}{ Project Cost Summary } \\
\hline Installed Equipment & & & & & & $24,444,898$ \\
\hline $\begin{array}{l}\text { Project Management, Engineering, } \\
\text { Construction Indirects, and Per- } \\
\text { mitting }\end{array}$ & & & & & & 922,469 \\
\hline Site Preparation & & & & & & 427,238 \\
\hline Grading, utilities installation & & & & & 146,072 & \\
\hline Foundations installation & & & & & 231,435 & \\
\hline Structural steel installation & & & & & 49,731 & \\
\hline $\begin{array}{l}\text { G\&A, R\&D, Sales \& Marketing, } \\
\text { Profit Allowance }\end{array}$ & & & & & & $6,835,358$ \\
\hline Total Plant Cost & & & & & & $32,629,963$ \\
\hline Spare Parts Allowance & & & & & & 553,181 \\
\hline Startup & & & & & & 150,000 \\
\hline Land & & & & & & 20,000 \\
\hline Total Capital Requirement & & & & & & $33,353,143$ \\
\hline
\end{tabular}


Table 3.19

Power System Cost-of-Electricity Estimate (PSOFC/ATS-GT/Ammonia-Water Power System)

\begin{tabular}{|l|r|l|r|}
\hline \multicolumn{2}{|c|}{ coE Calculation Basis } & \multicolumn{2}{c|}{ Cost Summary } \\
\hline $\begin{array}{l}\text { No. round-the-clock power system } \\
\text { operators }\end{array}$ & 1 & & \\
\hline No. plants on system & 5 & Fixed O\&M, \$/kW-year & 5.0 \\
\hline Operator labor cost, \$/man-hour & 75 & Plant operation \& control & 1.0 \\
\hline $\begin{array}{l}\text { Housekeeping maintenance, man- } \\
\text { hours/week/system }\end{array}$ & 20 & Housekeeping maintenance & 1.8 \\
\hline Housekeeping labor cost, \$/man-hour & 25 & $\begin{array}{l}\text { Administration (30\% of operation } \\
\text { \& maintenance labor) }\end{array}$ & 7.7 \\
\hline System rating, MW net ac & 26.5 & Total Fixed O\&M, \$/kW-year & \\
\hline Gas turbine rating, MW ac & 9.6 & & 1.3 \\
\hline Ammonia turbine rating, MW ac & 1.9 & Variable O\&M, mills/kWh & 0.8 \\
\hline $\begin{array}{l}\text { Ammonia-water power system main- } \\
\text { tenance cost, \$/kWh }\end{array}$ & 0.0106 & SOFC replacement & 1.4 \\
\hline $\begin{array}{l}\text { Gas turbine maintenance cost, \$/GT } \\
\text { kWh }\end{array}$ & 0.00377 & $\begin{array}{l}\text { Ammonia-water power system } \\
\text { maintenance }\end{array}$ & 0.1 \\
\hline $\begin{array}{l}\text { SOFC replacement cost, \$/SOFC } \\
\text { generator module }\end{array}$ & 468,920 & Gas turbine maintenance & 3.5 \\
\hline SOFC replacement internal, years & 10 & $\begin{array}{l}\text { Desulfurizer adsorbent/catalyst } \\
\text { replacement }\end{array}$ & \\
\hline Power plant capacity factor & 0.92 & Total Variable O\&M, mills/kWh & \\
\hline $\begin{array}{l}\text { Desulfurizer adsorbent \& catalyst, } \\
\$ / \text { year }\end{array}$ & 11,367 & & 23.4 \\
\hline $\begin{array}{l}\text { Interest rate (SOFC replacement cost } \\
\text { calculation), \% }\end{array}$ & 6.0 & Total O\&M COE, mills/kWh & 17.6 \\
\hline $\begin{array}{l}\text { Power system efficiency (net } \\
\text { AC/LHV), \% }\end{array}$ & 64.402 & Capital COE, mills/kWh & 45.6 \\
\hline Capital charge rate, \%/year & 15 & Fuel COE, mills/kWh & Total COE, mills/kWh \\
\hline Power system capital cost, \$/kW & 1,259 & & \\
\hline Fuel Cost, \$/MMBtu & 3.0 & & \\
\hline Fuel higher heating value, Btu/b & 21873 & & \\
\hline Fuel lower heating value, Btu/lb & 19711 & & \\
\hline
\end{tabular}




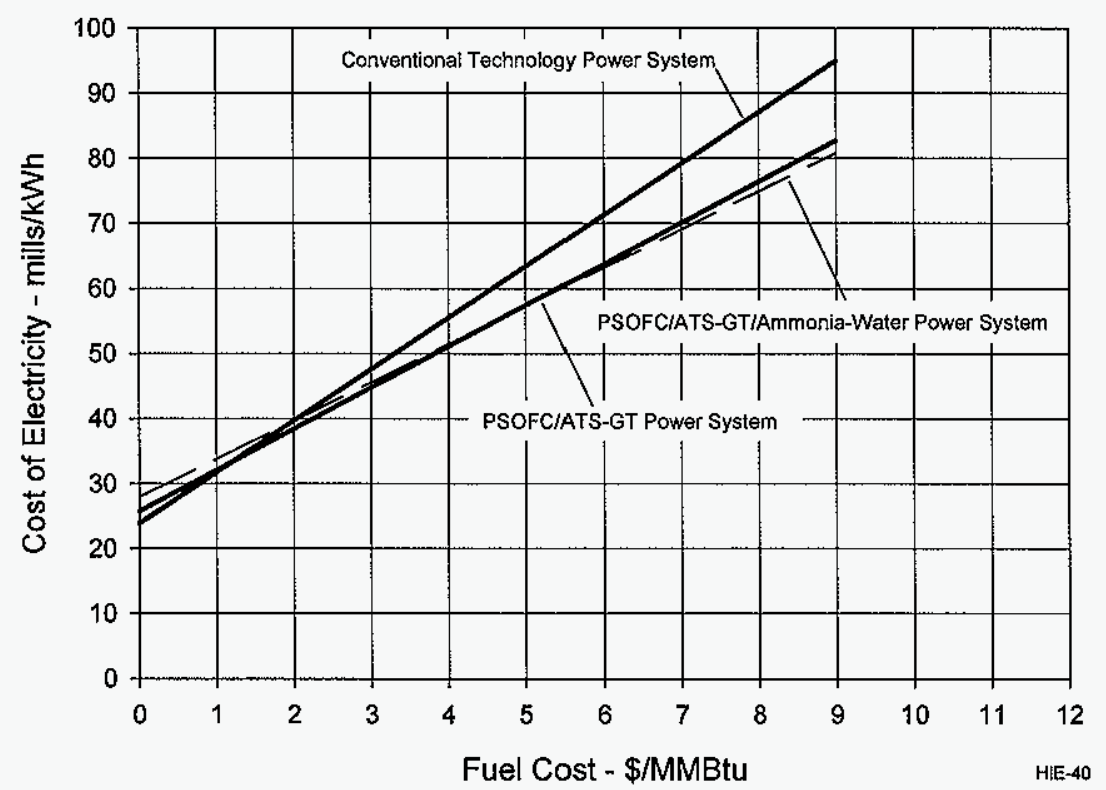

Figure 3-59 - COE estimates for the PSOFC/ATS-GT/ammonia-water power system.

\subsubsection{Effect of Power System Type on Emissions}

Estimates of $\mathrm{CO}_{2}, \mathrm{NOx}$, and SOx emissions for the PSOFC/ATS-GT power systems considered in this study are compared on a relative basis in Figure 3-60 with estimates for the conventional-technology system. For $\mathrm{CO}_{2}$, the PSOFC/ATS-GT systems show advantage due to their higher efficiencies, and it is noted that their COE advantage would increase further in localities in which a carbon tax is levied. Further, it is recalled that earlier discussion indicated that the PSOFC/ATS-GT systems involving the steam turbine and ammonia-water power cycles could have little COE advantage relative to the baseline PSOFC/ATS-GT power system. However, this assessment was based on no consideration of a carbon tax, and considering the tax would increase the economic attractiveness of the bottoming cycles.

The NOx estimates assumed an exhaust NOx concentration of 25 ppmv $\left(15 \% \mathrm{O}_{2}\right)$ for the conventional-technology power system, and $5 \mathrm{ppmv}\left(15 \% \mathrm{O}_{2}\right)$ for the PSOFC/ATSGT power systems. The latter value corresponds to the Mercury 50 development goal for operation on natural gas without the use of post-combustion pollution control devices. 
Similar to the effect of a carbon tax, a tax on NOx emission would improve the COE performance of the PSOFC/ATS-GT power systems relative to the conventional-technology COE, and it would also improve the COE performance of PSOFC/ATS-GT systems with bottoming cycles relative to the performance of the baseline PSOFC/ATS-GT system.

For the SOx comparison, the reference value for the conventional-technology power system was determined assuming a fuel sulfur content of 4 ppmv, per the project design requirements, and the installation of no sulfur-emission control hardware. For the PSOFC/ATS-GT estimates, it was assumed that all system fuel was processed by the fuel desulfurization system, and that the fuel sulfur content, per SOFC requirement, was reduced by the system from 4 ppmv to $0.1 \mathrm{ppmv}$.

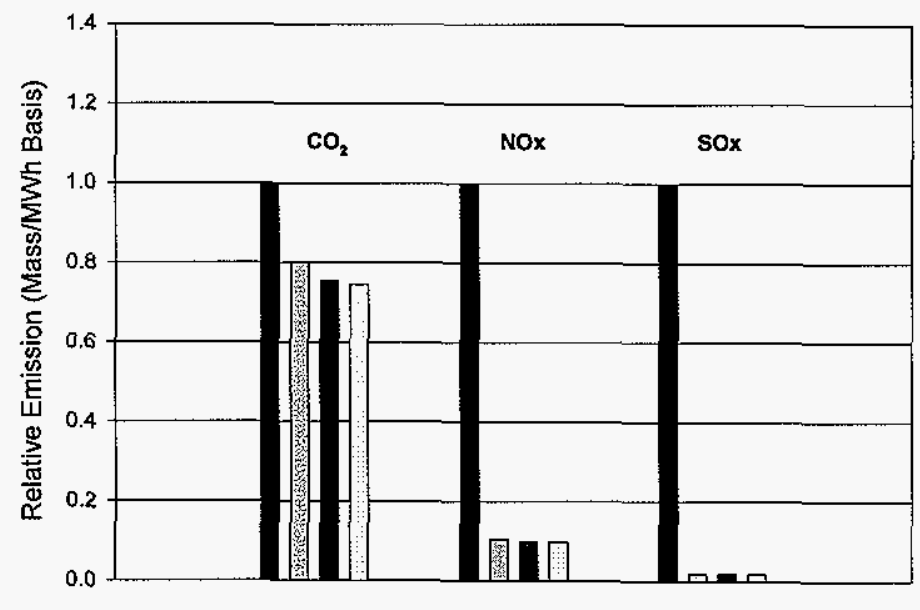

HIE-42

Figure 3-60 - Power system relative emissions estimates. 


\subsubsection{Power System Arrangement Studies}

The power plant arrangement studies investigated the differences resulting from use of SOFC modules that had process air inlet and exhaust nozzles on opposite ends versus the nozzles on the same end. Since the process air piping will be large, heavy, and expensive, arrangements were examined to minimize the quantity of process air piping.

The arrangement that minimizes the process air piping for SOFC modules with nozzles on opposite ends is the reference arrangement that is discussed in Section 3.1.4. Although the amount of piping is greater, it has been selected for ease of installation and continuing inspection and maintenance activities. It occupies a smaller amount of real estate than the plant arrangements that support SOFC modules with inlet and exhaust nozzles on the same end.

Three alternative plant arrangements that use SOFC module pressure vessels with process air connections on the same end were also considered. The alternative 1 system is depicted in Figure 3-61 and Figure 3-62, and alternative 2 is shown in Figure 3-63 and Figure 3-64, and alternative 3 is shown in Figure 3-65 and Figure 3-66.

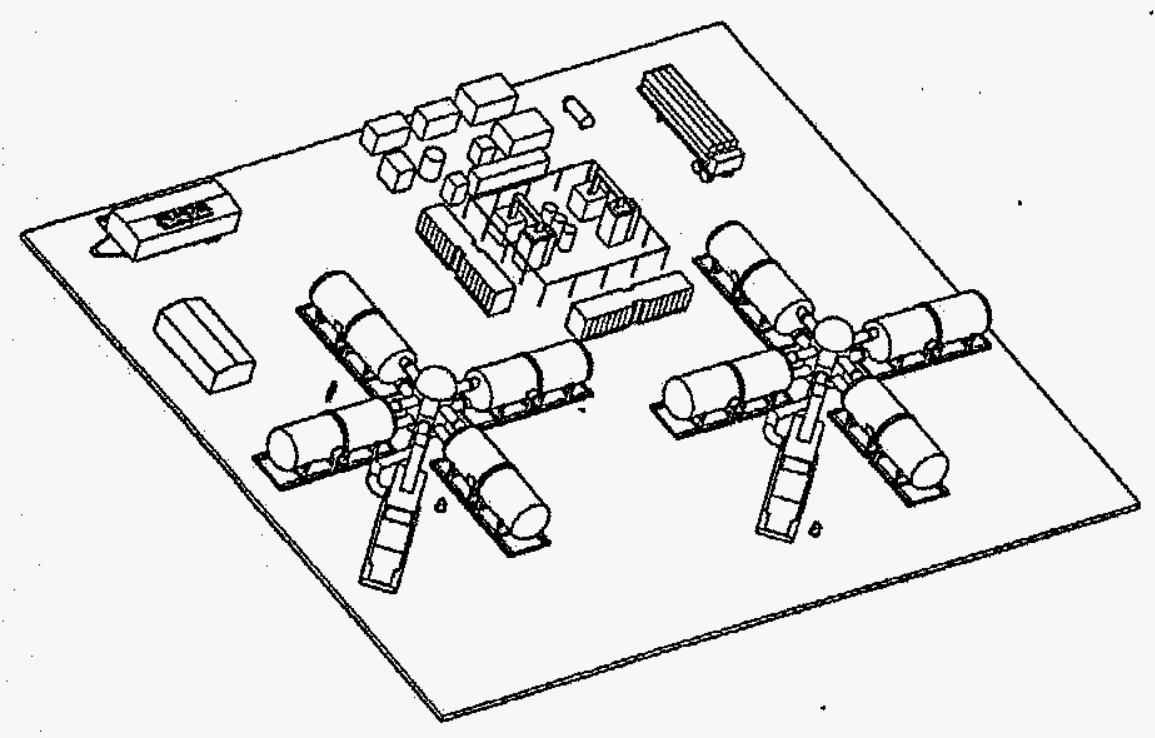

Figure 3-61 - Alternative 1 system arrangement - isometric view. 


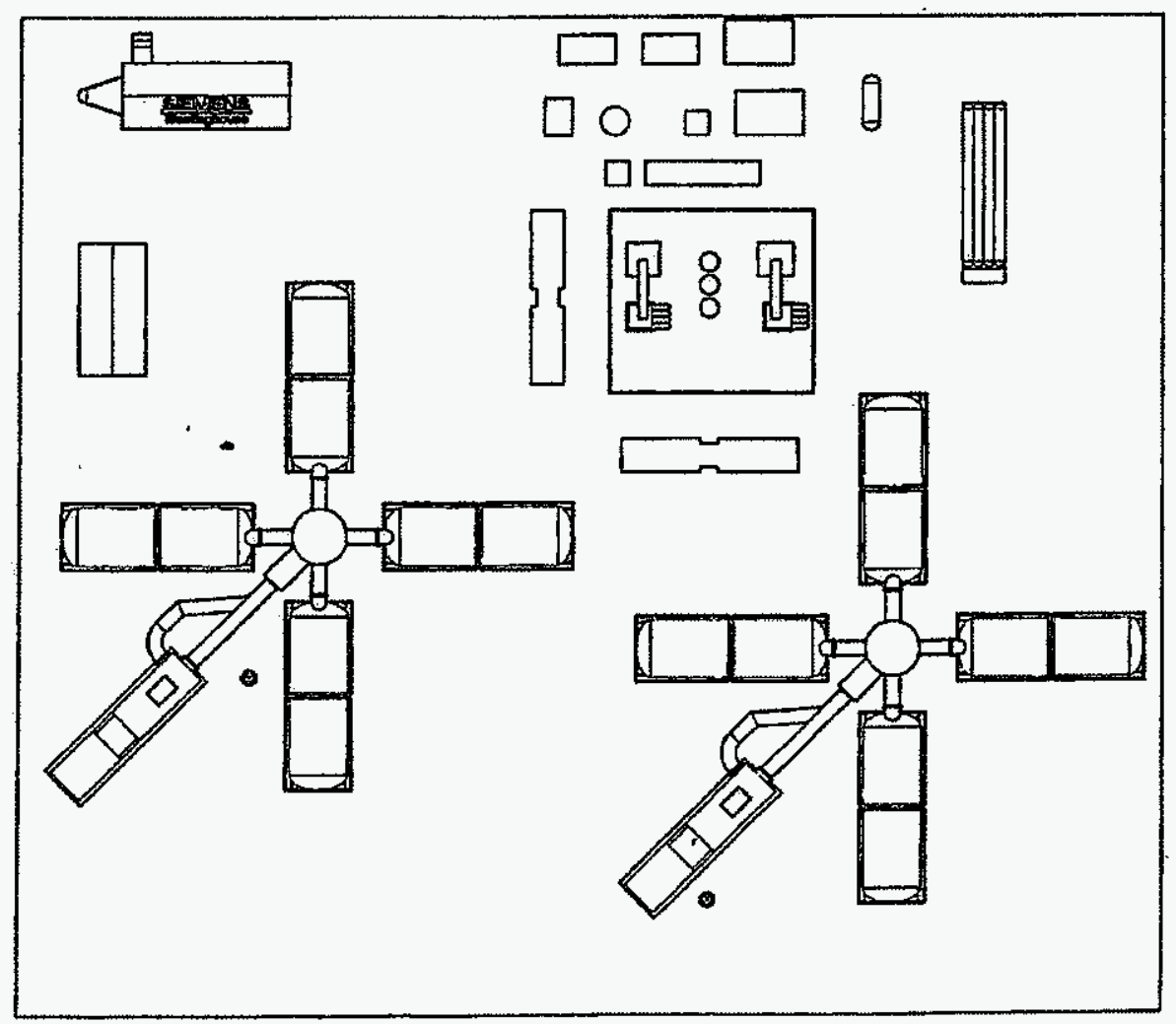

Figure 3-62 - Alternative 1 system arrangement — plan view. 


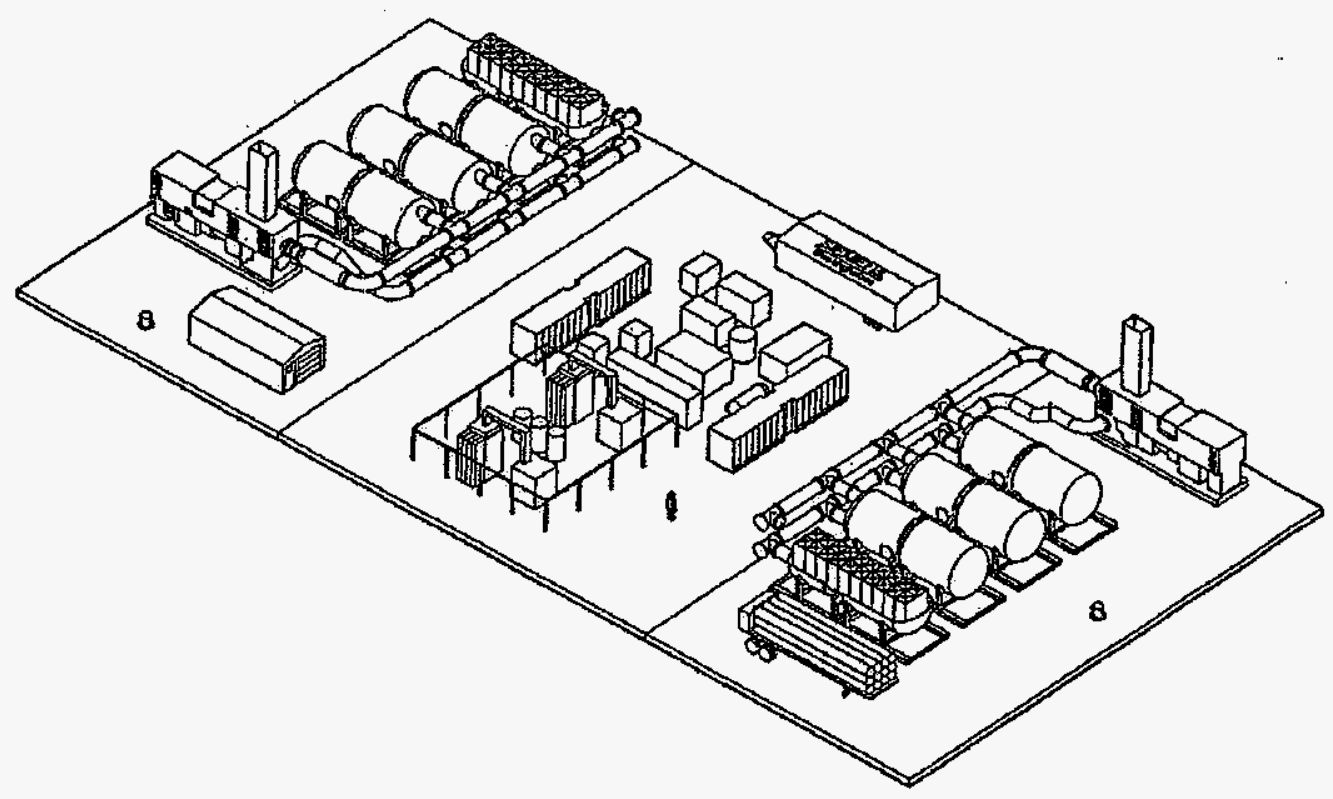

Figure 3-63 - Alternative 2 system arrangement - isometric view. 


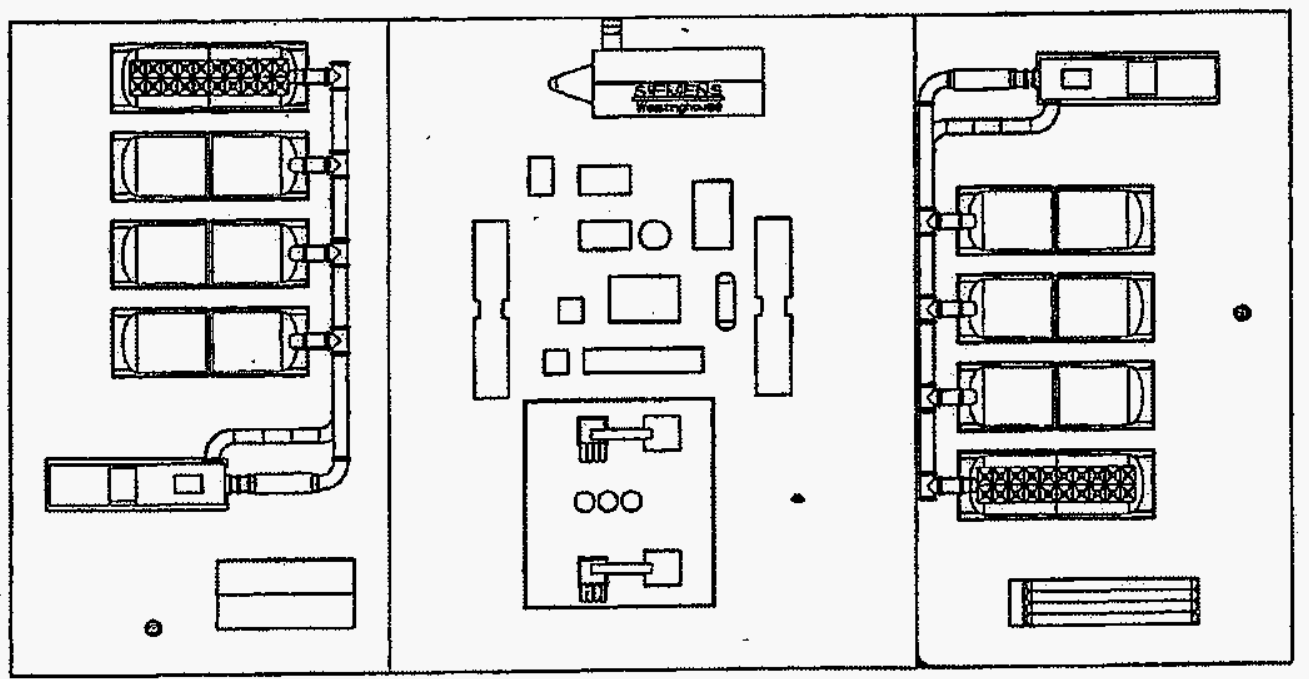

Figure 3-64 - Alternative 2 system arrangement — plan view. 


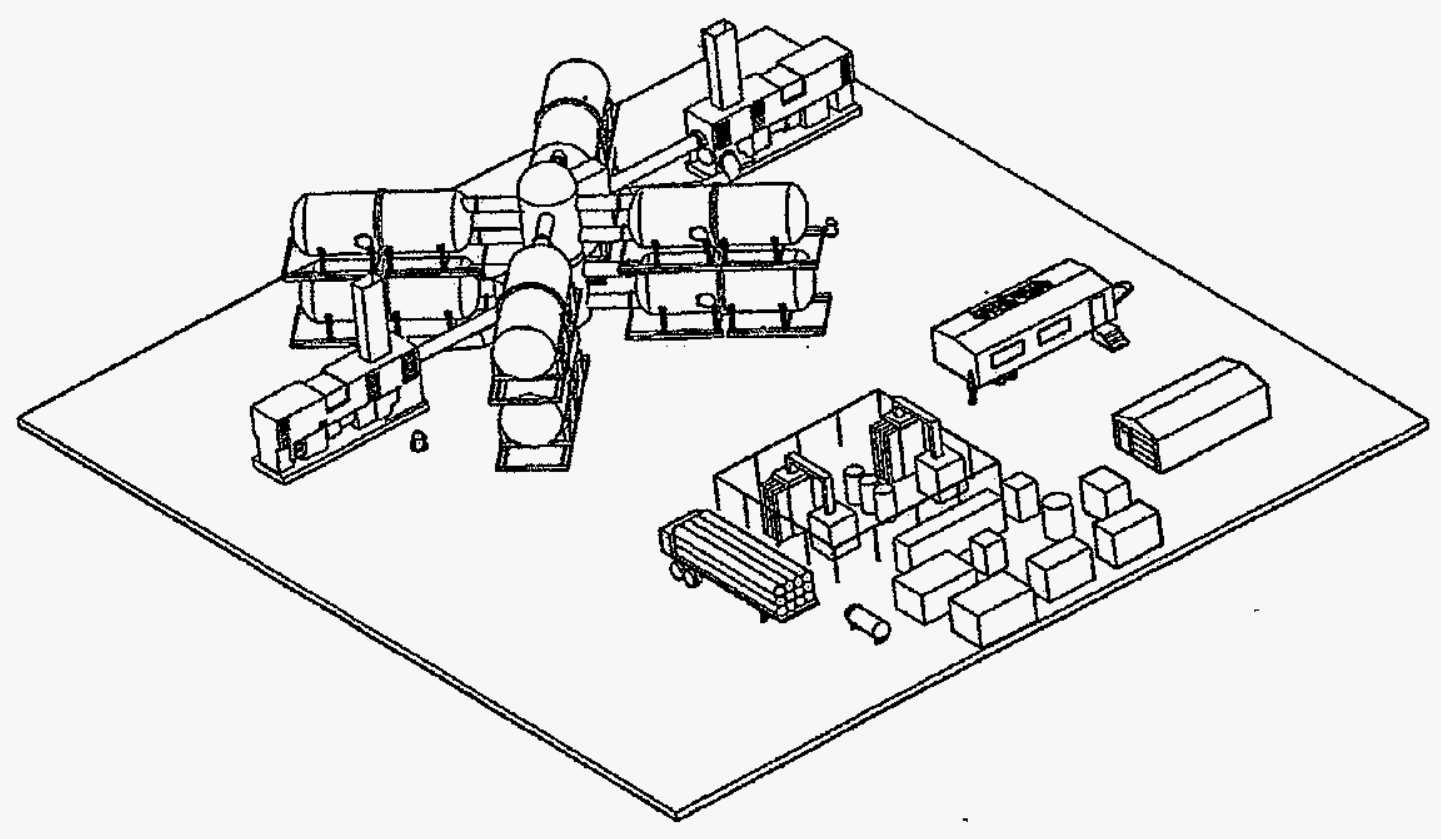

Figure 3-65 - Alternative 3 system arrangement - isometric view. 


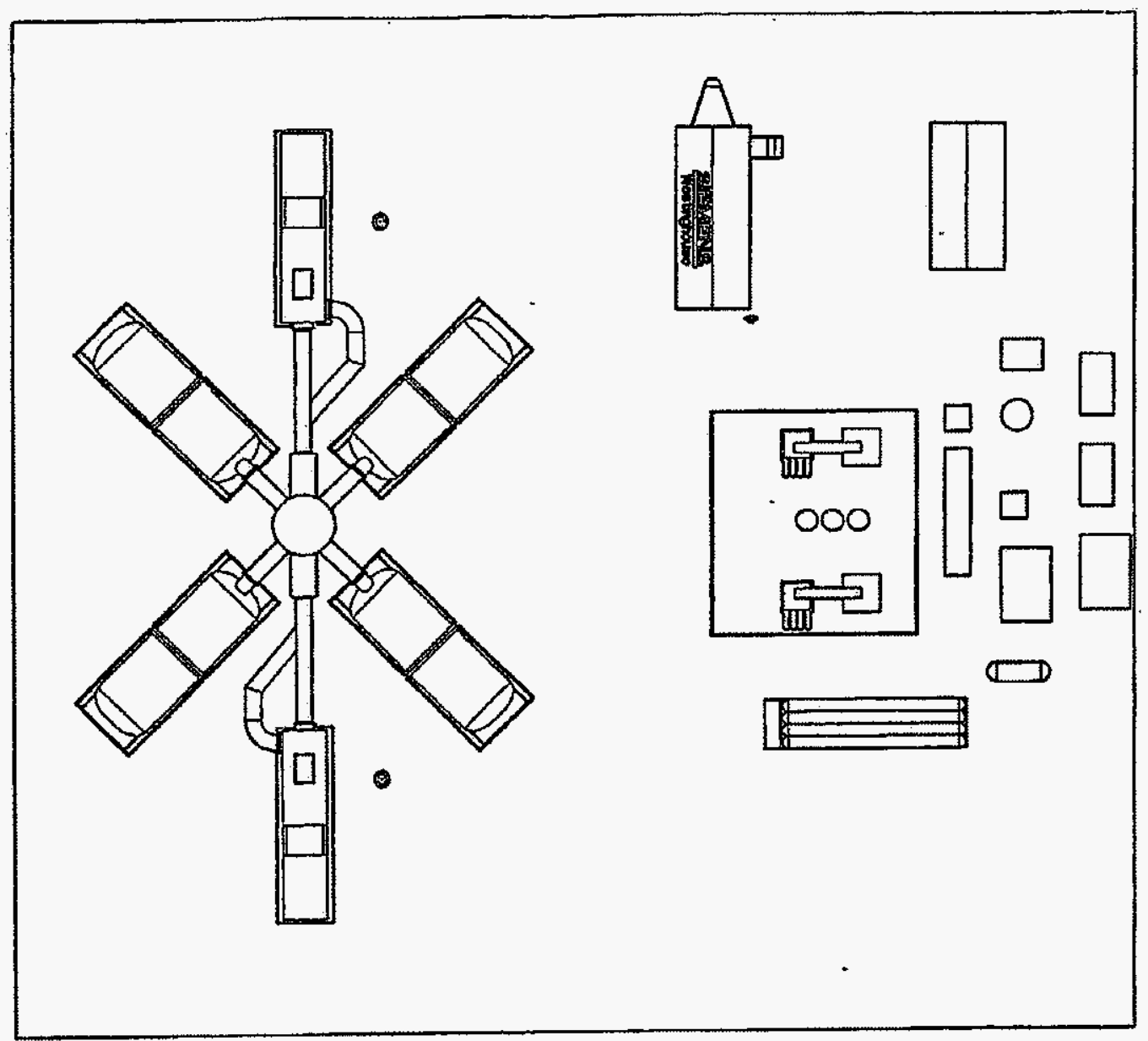

Figure 3-66 - Alternative 3 system arrangement - plan view. 


\subsubsection{Alternative 1 System Arrangement}

This arrangement is shown on a site $63 \mathrm{~m}$ (208 ft) by $56 \mathrm{~m}$ (183 ft), or 0.87 acres. The pressure vessels are set like the spokes of a wheel on radii from a central air distribution plenum, and a vessel design is used in which the process air inlet and outlet nozzles are on the same end of the vessel. The vessel and SOFC stack design are relatively more difficult due to the need to ensure uniform air distribution within the stack. Its advantage is the minimization of the quantity of large bore, internally and externally insulated piping. The cost savings for elimination of the process air piping is partially offset by the cost of the air distribution plena. This arrangement was investigated for its potential to yield lowest cost. It was hoped that the reduction in land area and process piping length would override the disadvantages. This was not the result. The advantage that was hoped to be gained by the alternative 1 configuration in its use of less land area did not materialize.

The primary disadvantages of the arrangement are inefficient routing of high voltage lines, difficult initial installation, and poor access to the SOFC vessels for maintenance.

\subsubsection{Alternative 2 System Arrangement}

This system would be installed on a site $69 \mathrm{~m}(226 \mathrm{ft})$ by $36 \mathrm{~m}(117 \mathrm{ft})$, or 0.61 acres. This site is only slightly larger than the preferred arrangement. The vessels are set in rows receiving and returning process air to air distribution headers at one end of the vessels. The vessel and SOFC stack designs are relatively more difficult due to the need to ensure uniform air distribution within the stack.

The alternative 2 site has vehicle access roadways on both ends of the vessels. Routing of high voltage electric power lines from the SOFC vessels to the switchyard is efficient.

The primary disadvantages of the arrangement are difficult initial installation and poor access to the SOFC vessel halves that have the process air nozzles.

\subsubsection{Alternative 3 System Arrangement}

This arrangement is a permutation of the alternative 1 arrangement with process air nozzles on one end of each vessel. The vessels are set like spokes of a wheel connected to 
a central air distribution plenum vessel. This arrangement occupies less land area than alternative one because the two power blocks are stacked one on top of the other. The plant site is smaller, only about 0.7 acre. Its dimensions are $51 \mathrm{~m}$ (166 ft) by $56 \mathrm{~m}$ (183 $\mathrm{ft}$ ).

The relative advantage to alternative 1 is a smaller amount of real estate. The disadvantages to this arrangement are many. Initial installation will be difficult and routing of electrical power lines will be inefficient. Routine inspection and maintenance will be extremely difficult.

\subsubsection{Desulfurization System Cost Study}

This study compared an ambient temperature activated carbon desulfurization system with a heated catalytic hydrolization and adsorption system. The results of the study shows the heated system to be advantageous as discussed below.

The demonstration SOFC plants have used activated carbon beds contained within carbon steel pressure vessels to desulfurize natural gas. The significant advantage of the activated carbon is that the process works at room temperature. The main disadvantage is that the process is not a strong chemical bonding on the carbon and that the amount of sulfur adsorbed per unit of carbon is relatively low. As a result, the activated carbon quantities are large or the adsorbent must be replaced too frequently.

A study was performed to assess the cost of using alternate sulfur adsorbents. The use of zinc oxide was found to be very attractive. The volumetric consumption of zinc oxide is about two orders of magnitude less than the consumption of activated carbon for the same duty. In order for zinc oxide to be effective, however, the natural gas temperature must be above $277^{\circ} \mathrm{C}\left(530^{\circ} \mathrm{F}\right)$. The optimum desulfurization temperature is at about $400^{\circ} \mathrm{C}\left(750^{\circ} \mathrm{F}\right)$. Operation at elevated pressures also produces a substantial improvement in sulfur removal.

If using activated carbon as an adsorbent, a $20 \mathrm{MW}_{\mathrm{e}}$ plant is projected to consume 173 $\mathrm{m}^{3}\left\langle 6100 \mathrm{ft}^{3}\right\rangle$ of activated carbon per year. The material replacement cost is $\$ 578,000$ at $\$ 2.50$ per pound. Additionally, the disposal cost is $\$ 145,000$ at $\$ 175$ per 55-gallon drum. Thus, the annual cost for activated carbon is $\$ 723,000$. 
This is compared to an estimated annual consumption of only $0.85 \mathrm{~m}^{3}\left(30 \mathrm{ft}^{3}\right)$ of zinc oxide, which operates at $12.4 \mathrm{barg}(180 \mathrm{psig})$ and $400^{\circ} \mathrm{C}\left(750^{\circ} \mathrm{F}\right)$. The replacement cost for this material is $\$ 8100$ at $\$ 270$ per cubic foot. The disposal cost is estimated as $\$ 715$ per year for four 55-gallon drums. The desulfurization process does not rapidly consume the cobalt molybdenum catalyst, and practical equipment can be designed to require replacement every ten years. Assuming ten-year changeout, the annual replacement cost is $\$ 920$ for two $0.57 \mathrm{~m}^{3}\left(20 \mathrm{ft}^{3}\right)$ Co-Mo catalyst beds. The spent cobalt-molybdenum can be sold to a reclaiming company for about $\$ 0.50$ per pound. This gain is offset by the shipping cost with the result being no net gain or loss to dispose of the Co-Mo. The annual cost for desulfurization adsorbent and catalyst cost is $\$ 9735$. Combined with the cost of consuming about $180 \mathrm{~kW}$ for electrolysis of water to produce hydrogen, the total annual desulfurization cost is about $\$ 90,000$, considerably less than the annual activatedcarbon cost. In addition, the first cost of the large vessels for activated carbon would be higher than the combined cost for the much smaller vessels for heated zinc oxide, the $\mathrm{H}_{2}$ generator, the natural gas recuperator and electric gas heater, even with the added complexity of supporting separate adsorbent and catalyst beds. Thus, the study concluded that the preferred fuel desulfurization technique would employ the cobalt molybdenum catalyst/zinc-oxide-adsorbent technique.

\subsubsection{Cover Gas System Cost Study}

This study compared three alternatives for ways to provide a protective nitrogen cover gas for the SOFC stacks. The alternatives were using purchased bottled nitrogen gas; purchased liquefied nitrogen, which would be vaporized and used as needed; or nitrogen gas generated and stored on site. The cost-effective alternative is the generatednitrogen approach.

The demonstration SOFC plants have relied upon supplies of NHMIX (nitrogen/hydrogen mixture) cover gas stored in pressurized bottles. Limited testing of SOFCs has shown that under some conditions it is not necessary to provide a reducing atmosphere on the fuel side of the SOFCs. It is expected that at the time that a $20 \mathrm{MWe}$ plant is supplied, the process may require a cover gas consisting only of nitrogen. This study proceeded on this assumption. 
In the current commodity gas market, $28.3 \mathrm{~m}^{3}\left(1000 \mathrm{ft}^{3}\right)$ of bottled nitrogen costs $\$ 12.03$.

The required quantity of nitrogen which must be stored at the plant are based on the following assumptions:

- The initial stack temperature is $566^{\circ} \mathrm{C}\left(1050^{\circ} \mathrm{F}\right)$. The stack-cooling rate after shutdown is $-3^{\circ} \mathrm{C} /$ minute. Cover gas is needed until the stack temperature is reduced to $260^{\circ} \mathrm{C}\left(500^{\circ} \mathrm{F}\right)$. Thus, the minimum supply of cover gas must be sufficient for 183 minutes.

- The amount of cover gas needed for starting up the plant is the same as that needed for cooling the plant after shut down.

- Seven percent margin is added to the calculated gas quantities for uncertainty and conservatism.

- $242.5 \mathrm{cc} /$ minute of nitrogen is needed for each SOFC. To support the 92,160 SOFCs in the plant, this results in $22 \mathrm{~m}^{3} / \mathrm{min}$ (790 scfm) of nitrogen.

Each plant start up or shut down consumes $4,380 \mathrm{~m}^{3}(155,000 \mathrm{scf})$ of nitrogen. The gas consumption cost is $\$ 1,859$ for nitrogen for a single shut down. For one plant start and stop per year, the direct annual gas usage cost is $\$ 3,718$. In addition to the cost of the gas, the demurrage for a large nitrogen tube trailer is $\$ 950 /$ month. The delivery fee for a trailer is built into the demurrage. Total costs for use of purchased bottled nitrogen gas is $\$ 15,108$ per year.

The costs for using purchased bottled gas are considered constant because the compressed gas industry is mature and gas is supplied as a commodity. Over a twenty year plant life, the total cover gas cost, based upon using bottled gases, is $\$ 302,000$.

The amount of nitrogen merits consideration for buying and storing in the liquid form. The dewar for storing $4,376 \mathrm{~m}^{3}(11,234$ pounds or $154,525 \mathrm{scf})$ of liquid nitrogen must be at least $70.8 \mathrm{~m}^{3}\left(250 \mathrm{ft}^{3}\right)$. Liquid nitrogen costs $\$ 3.40$ per $28.3 \mathrm{~m}^{3}$ (1000 scf). The delivery to fill the dewar will include an excess of $5 \%(225 \mathrm{lbm})$ to allow for vaporization. This cost is $\$ 552$ for $4,594 \mathrm{~m}^{3}$ (162,251 scf) of liquid nitrogen plus a $\$ 125$ delivery fee. Every month the dewar must be topped off with an additional $5 \%$ to maintain the minimum required inventory. This is an additional $\$ 28$ for the nitrogen plus a $\$ 125$ delivery fee. The monthly cost of dewar and instrumentation rental is $\$ 750$. The total cost for 
two fills of purchased liquid nitrogen, monthly replenishment and equipment rental, is $\$ 11,388$ per year. Over a twenty year plant life, the cover gas costs based upon using bottled hydrogen and liquid nitrogen sum to $\$ 228,000$.

As a basis of comparison, the installation of nitrogen generating equipment was assessed and resulted in the preferred (lowest cost) option. A prepackaged nitrogen generator system with accumulator, compressor, vent, pressure relief and pressure control is available for about $\$ 20,500$. The high-pressure gas storage bottles cost about $\$ 60,000$, for a total equipment cost of $\$ 80,500$. The unit has been sized to fill the highpressure storage accumulator in seven days. While operating, the unit will consume electrical power and compressed air. Once the accumulator is filled, the unit will normally be idle. It will start upon low-pressure demand signal from the accumulator and operate until the accumulator is refilled. The functional specifications for the unit are shown in Table 3.20.

Table 3.20 - Nitrogen Generator/Compressor Characteristics

\begin{tabular}{|c|c|}
\hline Nitrogen production rate & $28.3 \mathrm{~m}^{3} / \mathrm{hr}(1000 \mathrm{scf} / \mathrm{hr})$ \\
\hline Nitrogen pressure before compression & 6.9 barg (100 psig) \\
\hline Nitrogen pressure after compression & 165 barg (2400 psig) \\
\hline Nitrogen purity & $>98 \%$ \\
\hline Process used & Selective Membrane \\
\hline Package size & $\begin{array}{l}1.52 \mathrm{~m} \times 1.83 \mathrm{~m} \times 1.93 \mathrm{~m} \\
\left(60^{\prime \prime} \times 72^{\prime \prime} \times 76^{\prime \prime}\right)\end{array}$ \\
\hline Nitrogen separator storage tank & $1.9 \mathrm{~m}^{3}$ (500 gallons), ASME tank \\
\hline Nitrogen compressor accumulator & $\begin{array}{l}\text { Twelve }-2.19 \mathrm{~m}^{3}\left(77.5 \mathrm{ft}^{3}\right) \text { ASME / CGA bot- } \\
\text { tles }\end{array}$ \\
\hline Electrical power requirements & $\begin{array}{l}110 \mathrm{vac} / 60 \mathrm{~Hz} / 1 \text { phase for separator } \\
440 \mathrm{vac} / 60 \mathrm{~Hz} / 3 \text { phase, } 5 \mathrm{~kW} \text { for compressor }\end{array}$ \\
\hline Compressed air supply required & $1.9 \mathrm{~m}^{3} / \mathrm{min}(66 \mathrm{scfm}) @ 175 \mathrm{psig}$ \\
\hline
\end{tabular}

Table 3.21 summarizes the costs for the various options investigated for supply of a nitrogen system. 
Table 3.21 - Costs for Options Investi gated for Supply of Nitrogen System

\begin{tabular}{|l|l|l|l|}
\hline & \multicolumn{1}{|c|}{$\begin{array}{c}\text { Bottled } \\
\text { Nitrogen }\end{array}$} & \multicolumn{1}{|c|}{$\begin{array}{c}\text { Liquid } \\
\text { Nitrogen }\end{array}$} & $\begin{array}{c}\text { Nitrogen } \\
\text { Generating System }\end{array}$ \\
\hline & $\begin{array}{l}\$ 3,718 \text { Annual Gas } \\
\text { Cost (Delivery In- } \\
\text { cluded) }\end{array}$ & $\begin{array}{l}\$ 2,388 \text { Annual Gas Cost \& } \\
\text { Delivery Fees }\end{array}$ & $\begin{array}{l}\$ 20,500 \text { Initial } N_{2} \\
\text { Equipment Cost } \\
\text { (one time cost) }\end{array}$ \\
\hline & $\begin{array}{l}\$ 11,400 \text { Annual Bottle } \\
\text { Trailer Demurrage }\end{array}$ & $\begin{array}{l}\$ 9000 \text { Storage Dewar \& In- } \\
\text { strumentation Annual Rental }\end{array}$ & $\begin{array}{l}\$ 60,000 \text { Bottle Trailer } \\
\text { (one time cost) }\end{array}$ \\
\hline Annual Cost & $\$ 15,108$ & $\$ 11,388$ & $\$ 4025$ pro-rated \\
\hline 20 Year Cost & $\$ 302,000$. & $\$ 228,000$ & $\$ 80,500$ \\
\hline
\end{tabular}

\subsubsection{Hydrogen Gas Generation Cost Study}

Hydrogen is needed by the fuel desulfurization process and to scavenge oxygen impurity from the nitrogen generated on-site. There are several suppliers of commercially available hydrogen generating equipment both in the USA and Canada. A prepackaged hydrogen generator/compressor system with accumulator and pressure control is currently available for $\$ 245,000$, but can be purchased in quantity (>100 unit per year) for $\$ 61,250$ to $\$ 122,500$ (Supplier's estimates). The functional specifications for the unit are shown in Table 3.22.

Table 3.22 - Hydrogen Generator Characteristics

\begin{tabular}{|l|l|}
\hline Hydrogen production rate & $0.57 \mathrm{~m}^{3} / \mathrm{min}(20 \mathrm{scfm})$ \\
\hline Hydrogen pressure & $12.4 \mathrm{barg}(180 \mathrm{psig})$ \\
\hline Process used & Electrolysis \\
\hline Package size & $1.82 \mathrm{~m} \times 5.49 \mathrm{~m} \times 3.05 \mathrm{~m}$ high \\
& $(6 \mathrm{ft} \times 18 \mathrm{ft} \times 10 \mathrm{ft}) \mathrm{high}$ \\
\hline Package weight & $7484 \mathrm{~kg}(16,500 \mathrm{pounds})$ \\
\hline Hydrogen accumulator size & $119 \mathrm{sm}^{3}(4200 \mathrm{scf}) @$ \\
& $12.4 \mathrm{barg}(180 \mathrm{psig})$ or $8.98 \mathrm{~m}^{3}\left(317 \mathrm{ft}^{3}\right)$ \\
\hline Power & $180 \mathrm{~kW}$ \\
\hline Water consumption & 35 liters $/ \mathrm{hr}(9.24 \mathrm{gph})$ \\
\hline
\end{tabular}

\subsubsection{Process Piping Cost Study}

The first task in the process piping cost study was to determine the required flow area. When the airflow was assumed to be about $61 \mathrm{~m} / \mathrm{sec}$ (200 fps or $\sim 10 \%$ of sonic speed) an internal protective liner was necessary to prevent erosion of the insulation. At air temperatures in the range of $815^{\circ} \mathrm{C}$ to $870^{\circ} \mathrm{C}\left(1500\right.$ to $\left.1600^{\circ} \mathrm{F}\right)$ metallic liners are unsuitable for except for short lengths due to their high thermal expansion. Ceramic liners 
were found which have excellent erosion resistance but are unsuitable for other reasons. The ceramic liner materials are necessarily dense with high thermal conductivity and are fabricated by casting. The casting process requires a thickness of one inch. This dense ceramic adds $5 \mathrm{~cm}$ (two inches) to the piping inner diameter, provides no thermal insulation benefit, adds weight and is a very costly process.

When the inner flow area was selected to keep the gas speed to less than $30 \mathrm{~m} / \mathrm{sec}$ (100 fps), conventional vacuum-formed alumina-silica insulation can be used. This does require that the piping be larger, but the complexity of fabricating insulated piping results in lower total cost.

The estimated costs of internally and externally insulated piping for the $20 \mathrm{MW}_{\mathrm{e}}$ plant are shown in Table 3.23 .

Table 3.23 - High Temperature Piping(1) Costs

\begin{tabular}{|c|c|c|c|}
\hline Application & $\begin{array}{l}\text { Open Flow Area } \\
\text { ID, inches }\end{array}$ & $\begin{array}{c}\text { Pipe Size } \\
\left(0.375^{\prime \prime} \text { wall }\right)\end{array}$ & $\begin{array}{l}\text { Cost per lin- } \\
\text { ear foot }^{(2)}\end{array}$ \\
\hline Header & 22 & 38 & $\$ 1104$ \\
\hline Branch & 12 & 28 & $\$ 785$ \\
\hline
\end{tabular}

Notes:

1. 3 " exterior insulation

2. Cost for piping and insulation only, no fittings, flanges or bolting materials

\subsection{References}

1. Erickson, D.C., Papar, R., Anand, G., and Tang, J., Refinery Waste Heat Powered Absorption Refrigeration - Cycle Specification and Design, Proceedings of ASME, AES-Vol. 38, pp. 391-402, 1998.

2. Erickson, D.C., and Anand, G., Absorption-Augmented Engine Refrigeration, ASHRAE Transactions, Vol. 105, 1999.

3. Erickson, D.C., and Anand, G., Absorption Power Cycle with Two Pumped Absorbers, Patent Pending. 


\section{CONCLUSIONS}

- A low-cost, highly-efficient (60\%) 20 MWe-class PSOFC/ATS-GT hybrid power system concept has been devised that employs the 4.5 MWe Solar Turbines Mercury ${ }^{\mathrm{TM}}$ 50 gas turbine that was developed under the DOE ATS program. The projected hybrid cycle power system COE is $44.8 \mathrm{mills} / \mathrm{kWh}$, which is $6 \%$ less than the estimated COE for a conventional $20 \mathrm{MW}$-class gas turbine combined cycle power system. These estimates apply to a fuel cost of $\$ 3 / \mathrm{MMBtu}$. Due to its higher operating efficiency, the PSOFC/ATS-GT power system would have increased COE advantage at higher fuel costs.

- The PSOFC/ATS-GT power system efficiency estimate is $59.9 \%$ (net AC/LHV), twelve points higher than that achieved by the conventional-technology gas turbine combined cycle power system. This estimate is based upon mature-product cell V-I characteristics that are expected to be available in the 2005 to 2010 time period, and upon current Mercury ${ }^{\mathrm{TM}} 50$ performance.

- An SOFC PCS concept was developed that has an estimated DC-to-grid AC conversion efficiency of $95 \%$ and an installed cost of approximately $\$ 220 / \mathrm{DC} \mathrm{kWe}$.

- By equipping the PSOFCIATS-GT power system with a bottoming cycle (steam turbine or ammonia-water), the overall system power output and efficiency will increase. However, due to the accompanying increases in system installed and O\&M costs, the gains in power output and efficiency do not necessarily translate to significant $\mathrm{COE}$ reductions. It is likely that the economic attractiveness of adding a bottoming cycle to the baseline PSOFC/ATS-GT power system would increase if taxes on power system emissions were levied.

- The staged-cell SOFC stack design does not offer the large SOFC efficiency gain (over the standard cocurrent axial flow stack design) that was projected originally. Cell cooling in the fuel-entry cell rows reduces the average cell voltage while there is little increase in average fuel utilization at the last cell row at meaningful current densities because of the hazard of anode oxidation. 


\section{Recommendations:}

- Development of the PSOFC/ATS-GT power system concept should continue to refine the conceptual design and performance estimates, establish the method of operating (startup, power operation, shutdown) the PSOFC/ATS-GT power system, identify and resolve SOFC and Mercury ${ }^{\mathrm{TM}} 50$ integration issues, and develop a plan to demonstrate the power system concept.

- The PCS efficiency has a significant effect on the overall power system efficiency. For example, a gain in PCS efficiency of one percent translates to a system efficiency gain that approaches $6 / 10$ of one percentage point. Additional conceptual work should be done to determine if PCS efficiency gains above the $95 \%$ value developed and applied in this study could be achieved cost-effectively.

- SOFC development should be pursued to improve fuel cell power density and efficiency. As with the SOFC PCS, improvements in cell efficiency would be effective in increasing the efficiency of SOFC/GT power systems. 


\section{APPENDIX A}

\section{The Effect of Staging on Efficiency of Isothermal SOFC Stacks}


The purpose of this section is to describe the effect of staging the fuel stream on the efficiency of fuel cells. Staging of the fuel flow path is described as having the fuel pass a number of separate or segmented electrical circuits on its way through the fuel cell array. The current density is not uniform within any cell or stage that has a large difference in fuel concentration between the inlet and outlet locations. The terminal voltage across a stage is uniform, but the internal Nernst potential varies due to the change in reactant concentrations. With staging, one can either divide the cell structure into many regions or the fuel supply for many cells can pass sequentially through or past the cells. With staging the current density distribution becomes more uniform because the Nernst potential varies by a smaller amount within each stage. More uniform current density lowers the Joule losses and polarization losses. The voltage gain in the fuel rich stages is greater than the loss in the fuel poor stages.

It will be shown that the improvement in efficiency is small at economically viable operating current density conditions, namely at current densities near the maximum power point. The maximum power point occurs at the current density that maximizes the power output per unit area of the cell.

\section{ISOTHERMAL ANALYSIS}

The analysis is simplified by assuming that leakage of $\mathrm{O}_{2}$ is negligible, that the cells are isothermal, and that the cathode gas is supplied at high stoich conditions. These conditions are favorable to the benefits of staging. For example, non-isothermal conditions within a stage create restraints on the flow and geometrical arrangements necessary to achieve uniform fuel consumption within the stages.

Consider that the fuel is being consumed by an electrochemical conversion as it flows along a path through a number of stages. The properties used in the analysis are applicable to solid oxide fuel cells but the generalized analysis is independent of the specific cell geometry. If the total in-stack fuel consumption along the path is $F_{c}$, the consumption in each of the $n$ stages will be $F_{d} / n$ and the consumption at the end of stage $i$ is $z_{i}=$ $(i / n) F_{c}$. The local fuel consumption within a stage is denoted by $z$. The change in consumption, $d z$, that occurs in elemental area, $d A$, is related to the local current density, $\mathrm{j}$, by 


$$
d z=F_{c}\left(j d A / I_{o}\right)=\left(F_{c} / j_{a v}\right) j d A / A_{o}=\left(F_{c} / j_{\text {av }}\right) j d x
$$

or

$$
\mathrm{d} x / \mathrm{dz}=\mathrm{j}_{\mathrm{av}} /\left(\mathrm{j} \mathrm{F}_{\mathrm{c}}\right)
$$

where $\mathrm{dA} / \mathrm{A}$ has been replaced by $\mathrm{dx}$.

If one also assumes that the electrical potential produced by $\mathrm{CO}$ is equal to that produced by $\mathrm{H}_{2}$, the fuel mole fraction (the sum of $\mathrm{H}_{2}$ and $\mathrm{CO}$ mole fractions) is uniquely determined by the fuel consumption and the inlet composition. Thus with uniform cathode concentration or cathode composition also a function of consumption, the Nernst potential can be stated to be a function of the fuel consumption, $E_{n}=E_{n}(z)$.

The local current density at a location where the fuel consumption is $z$ is given by

$$
j=\left(E_{n}(z)-v_{i}\right) / R_{c}
$$

Substituting this into equation (1) gives

$$
d x / d z=\left(j_{a v} R_{c} / F_{c}\right) /\left(E_{n}(z)-v_{i}\right)
$$

After integration over the stage, the equation defining the cell voltage in each stage becomes

$$
\int_{z_{i-1}}^{z_{i}} \frac{R_{c} d z}{\left(E_{n}(z)-v_{i}\right)}=\frac{F_{c} \Delta x}{j_{a v}}
$$

For $n$ equal area stages, $\Delta x=1 / n$ for each stage. The solution for the $v_{i}$ of each stage is found by iteration using numerical integration of equation (4). If the resulting value of $\Delta x$ is too small/large for an assumed $v_{i}$, the value of $v_{i}$ in the next iteration must be increased/decreased subject to the limit that $0<v_{i} \leq E_{n}\left(z_{i}\right)$. The cell resistance, $R_{c}$, was calculated as the sum of the internal resistance, the diffusion polarization resistance for each electrode, and the activation polarization resistance. The polarization resistances were obtained by dividing the anode or cathode polarization by the local current density. After one obtains the $v_{i}$, it is easy to plot the current density versus the non-dimension area using the values from the final iteration. The value of dimensionless area, $x$, corresponding to a given value of $z$ in stage $i$ is given by 


$$
x=(i-1) \Delta x+\frac{j_{a v}}{F_{c}} \int_{z_{i-1}}^{z} \frac{R_{c} d z}{\left(E_{n}(z)-v_{i}\right)}
$$

The current density at this $x$ location is given by equation (2).

\section{RELATIONS FOR MOLE FRACTIONS, DIFFUSION POLARIZATION, AND NERNST POTENTIAL}

The mole fraction of fuel in the anode gas stream at fuel consumption $z$ is

$$
y_{F}(z)=y_{F o}(1-z)
$$

The mole fraction of oxygen in the cathode gas stream at fuel consumption $z$ is

$$
y_{O}(z)=\frac{(1-z / s)}{\left(1 / y_{O O}-z / s\right)}
$$

where $y_{O O}$ is the mole fraction of oxygen at inlet to the stack. The partial pressure of oxygen in the anode gas stream is found using an effective equilibrium constant for the methane derived fuel mixture,

$$
p_{O A}(z)=\left\{\frac{\left(1-y_{F}(z)-y_{N}\right) K}{y_{F}(z)}\right\}^{2}
$$

The Nernst potential based on the concentration in the gas streams is

$$
E_{n}(z)=\frac{R T}{4 F} \ln \left(\frac{p y_{O}(z)}{p_{O A}(z)}\right)
$$

The anode diffusion polarization is

$$
\eta_{A}=\frac{R T}{4 F} \ln \left(\frac{p_{O A}(z)}{p_{O A E}(z)}\right)
$$

where

$$
\begin{aligned}
& p_{O A E}(z)=K^{2}\left(\frac{1-y_{N}-y_{F A E}(z)}{y_{F A E}(z)}\right)^{2} \\
& y_{F A E}(z)=y_{F}(z)-j(z) / S_{3}
\end{aligned}
$$




$$
p_{O A}(z)=K^{2}\left(\frac{\left(1-y_{N}-y_{F}(z)\right.}{y_{F}(z)}\right)^{2}
$$

The cathode diffusion polarization is

$$
\eta_{C}=-\frac{R T}{4 F} \ln \left(1-j(z) / S_{1} y_{O}(z)\right)
$$

\section{ISOTHERMAL ANALYSIS RESULTS}

The example is based on representative properties of a solid oxide fuel cell at $1000^{\circ} \mathrm{C}$. The fuel composition is: $96 \%$ methane, $2 \%$ nitrogen and $2 \% \mathrm{CO}_{2}$. The fuel composition at the first stage inlet is based on internal reformation with a recirculation ratio that gives an oxygen to carbon ratio, OCR, equal to 2.1. Results are obtained at two system fuel consumption levels, $85 \%$ and $95 \%$. The corresponding in-stack fuel consumption values, $F_{c}$, are 0.6839 and 0.8946 . The combined fuel mole fraction of the inlet fuel is $y_{F_{0}}=$ 0.6326 for both fuel consumption levels.

The reference current density was selected to be the value that gives the maximum power density for a single stage cell configuration. A plot of terminal voltage and power density as a function of current density is shown in Figure A.1 for $F_{c}=0.85$. The values of current density at the maximum power point are $j_{\max P}=0.522$ and $0.498 \mathrm{~A} / \mathrm{cm}^{2}$, for the 0.85 and 0.95 fuel consumption values, respectively.

Figure A. 2 compares the current density and voltage distributions for single stage and four stage configurations at maximum power density for $85 \%$ system fuel consumption. For the four stage configuration, the total area is divided into four equal parts. The upper two curves, the Nernst potentials, are almost indistinguishable. The middle set of curves show the uniform voltage of the single stage and the four individual voltages of the four stage configuration. The bottom set of curves compare the current density distributions. Note that the maximum to minimum change in current density is reduced for the four-stage case. Since the average stage voltage is higher than the single stage voltage at the same current density and fuel consumption, the ratio of voltage in the same as the ratio of average power densities of the staged versus single stage cells. The average power density for this current density is increased by $0.58 \%$ above the value for a single stage cell for the limiting case of 16 stages. 
Figures A.3 and A.4 show the same comparison at reduced current densities, $j_{\max } / 5$ and $\mathrm{j}_{\max } / 20$, respectively. The staged power density only increases significantly at the lower current densities. Note that current density scales were changed in these figures to separate the two sets of curves.

Figures A.5, A.6, and A.7 provide similar comparison for $95 \%$ system fuel consumption. Table A.1 compares improvements in power density at 16 stages to that at a single stage. This table illustrates that the power density can be increased by significant amounts at a specified current density only for power densities that are well below the maximum power point. Thus the benefit of increased efficiency due to staging is only available at low power densities. Since staging is only beneficial at low power per cell, many more cells are required to compensate for the low power operation. Figure A.8 shows the relative number of cells required for a fixed plant output as a function of the current density.

The analysis was also applied to a generic planar cell configuration with a significantly lower total effective resistance. The total resistance including concentration polarization losses was held constant at $0.20 \mathrm{ohm}-\mathrm{cm}^{2}$. The maximum power density for this single stage planar cell occurs at a current density of $2.10 \mathrm{~A} / \mathrm{cm}^{2}$ for $F_{c}=85 \%$ and at 2.05 $\mathrm{A} / \mathrm{cm}^{2}$ for $F_{\mathrm{c}}=95 \%$.

The increase in power output for Siemens Westinghouse cylindrical cells is compared to that of planar cells in Figure A.9. The curves show the increase in power output as a result of staging. The increase is shown as a percentage of the power output of the corresponding single stage cell. The current density has been made dimensionless on the respective current density at the maximum power point for the single stage cell condition. It is seen that the use of normalized current density results in an excellent correlation of the improvement in efficiency due to staging. The slight difference in the curves for the two geometries is due to the change in diffusion polarization resistance with current density in the cylindrical cell model. Otherwise the gains appear to be a function of normalized current and utilization.

Although the curve shows significant increase in output for $F_{c}=0.95$, the partial pressure of $\mathrm{O}_{2}$ at the anode/electrolyte interface exceeds the limit which is two orders of magnitude less than the equilibrium partial pressure of $\mathrm{O}_{2}$ for the $\mathrm{Ni} / \mathrm{NiO} / \mathrm{O}_{2}$ reaction. Oxidation of the anode is considered likely under these conditions. The diffusion con- 
ductance of Siemens Westinghouse Power Corporation cells was used to evaluate the partial pressure of fuel at the electrolyte interface. For recirculated fuel, the fuel utilization limit is $\mathrm{FU}=91 \%$ when the partial pressure of $\mathrm{O}_{2}$ is maintained below the limit given above.

The effect of once through fuel flow on the increase in output due to staging was also considered. With the same fuel supply, external reformation at oxygen to carbon ratio of 2.1 gives a fuel inlet mole fraction of 0.780 . The in-stack fuel utilization value equals the system fuel utilization. Results for the planar cell with constant resistance are shown in Figure A.10 for $85 \%$ and $95 \%$ system fuel utilization. As expected, the gain due to staging increases significantly if one can push the operation to higher fuel utilization for once through fuel flow (external fuel reformation). Limiting the partial pressure of $\mathrm{O}_{2}$ to two orders of magnitude below the equilibrium value restricts fuel utilization to $\mathrm{FU}=89 \%$.

\section{SUMMARY OF ISOTHERMAL ANALYSIS}

The results demonstrate that the effect of fuel staging on fuel cell power output is very small for current densities near the maximum power point. This is shown to be valid also for other geometries that have considerably lower resistance than the cylindrical cell. With fuel recirculation, the output at the maximum power point increases by 0.58 and $1.15 \%$ at 85 and $95 \%$ fuel utilization, respectively. The improvement due to fuel staging increases as current density is reduced or as fuel utilization is increased. Oxidation of the fuel electrode is likely with recirculated fuel for utilization above $91 \%$.

The improvement due to staging is greater for systems with once through fuel flow as compared to those with recirculated fuel. However, oxidation of the anode is likely for once through flow when fuel utilization exceeds $89 \%$. Although fuel staging could increase output at low current densities by more than $10 \%$ at $95 \%$ utilization, the low power density would result in a large increase in system cost. 


\section{Nomenclature for Appendix A}

\begin{tabular}{|c|c|}
\hline$A_{0}$ & Total cell area, $\left[\mathrm{cm}^{2}\right]$ \\
\hline$E_{n}$ & Nernst potential, [V] \\
\hline$F_{c}$ & In-stack fuel consumption, [-] \\
\hline$F_{\text {cs }}$ & Overall system fuel consumption, [-] \\
\hline lo & Total cell current generated by $n$ stages $=j_{a v} A_{\circ}$. \\
\hline i & Stage index, [-] \\
\hline j & Local current density, $\left[\mathrm{A} / \mathrm{cm}^{2}\right]$ \\
\hline $\mathrm{j}_{\mathrm{av}}$ & Average current density for the stage, $\left[\mathrm{A} / \mathrm{cm}^{2}\right]$ \\
\hline $\mathrm{I}_{\operatorname{maxP}}$ & $\begin{array}{l}\text { Current density that gives maximum average power density for a single stage } \\
\text { Cell, }\left[\mathrm{A} / \mathrm{cm}^{2}\right]\end{array}$ \\
\hline K & Effective equilibrium constant for the methane derived fuel mixture, [-] \\
\hline$n$ & Number of stages, $[-]$ \\
\hline $\mathrm{p}$ & Pressure of the fuel cell gases, [Atm] \\
\hline $\mathrm{Pd}$ & Average power density, $\left[\mathrm{W} / \mathrm{cm}^{2}\right]$ \\
\hline $\mathrm{p}_{\mathrm{OA}}(z)$ & Local partial pressure of oxygen in the anode gas stream, [Atm] \\
\hline $\mathrm{P}_{\mathrm{OAE}}(\mathrm{z})$ & Local partial pressure of oxygen at the anode electrolyte, [Atm] \\
\hline$R_{c}$ & Cell resistance index, $\left[0 h m-\mathrm{cm}^{2}\right]$ \\
\hline $\mathrm{S}_{1}$ & Diffusion conductance of the air electrode at one Atm, $\left[\mathrm{A} / \mathrm{cm}^{2}-\mathrm{Atm}\right]$ \\
\hline $\mathrm{S}_{3}$ & Diffusion conductance of the fuel electrode at one Atm, [Atm $/ \mathrm{cm}^{2}-$ Atm] \\
\hline$v_{i}$ & Terminal voltage of stage i, [V] \\
\hline$x$ & Non-dimensional cell area, $=$ A/Ao, $[-]$ \\
\hline$\Delta \mathrm{x}$ & Non-dimensional area per stage, [-] \\
\hline$y_{F}(z)$ & Mole fraction of fuel in the anode gas at fuel consumption $z,[-]$ \\
\hline $\mathrm{Y}_{\mathrm{FAE}}(\mathrm{z})$ & Mole fraction of fuel at the anode electrolyte at fuel consumption $z,[-]$ \\
\hline$y_{F o}$ & Fuel mole fraction in anode gas at inlet to the stack, $[-]$ \\
\hline $\mathrm{y}_{\mathrm{N}}$ & Mole fraction of nitrogen in the fuel at inlet to the stack, $[-]$ \\
\hline yolz & Mole fraction of oxygen in the cathode gas stream at fuel consumption z, [-] \\
\hline Yoo & Mole fraction of oxygen in the cathode gas at inlet to the stack, $[-]$ \\
\hline$z$ & Local in-stack fuel consumption, [-] \\
\hline$z_{i}$ & In-stack fuel consumption at exit of stage i, [-] \\
\hline$\eta_{A}$ & Anode diffusion polarization, [V] \\
\hline$\eta_{c}$ & Cathode diffusion polarization, [V] \\
\hline
\end{tabular}




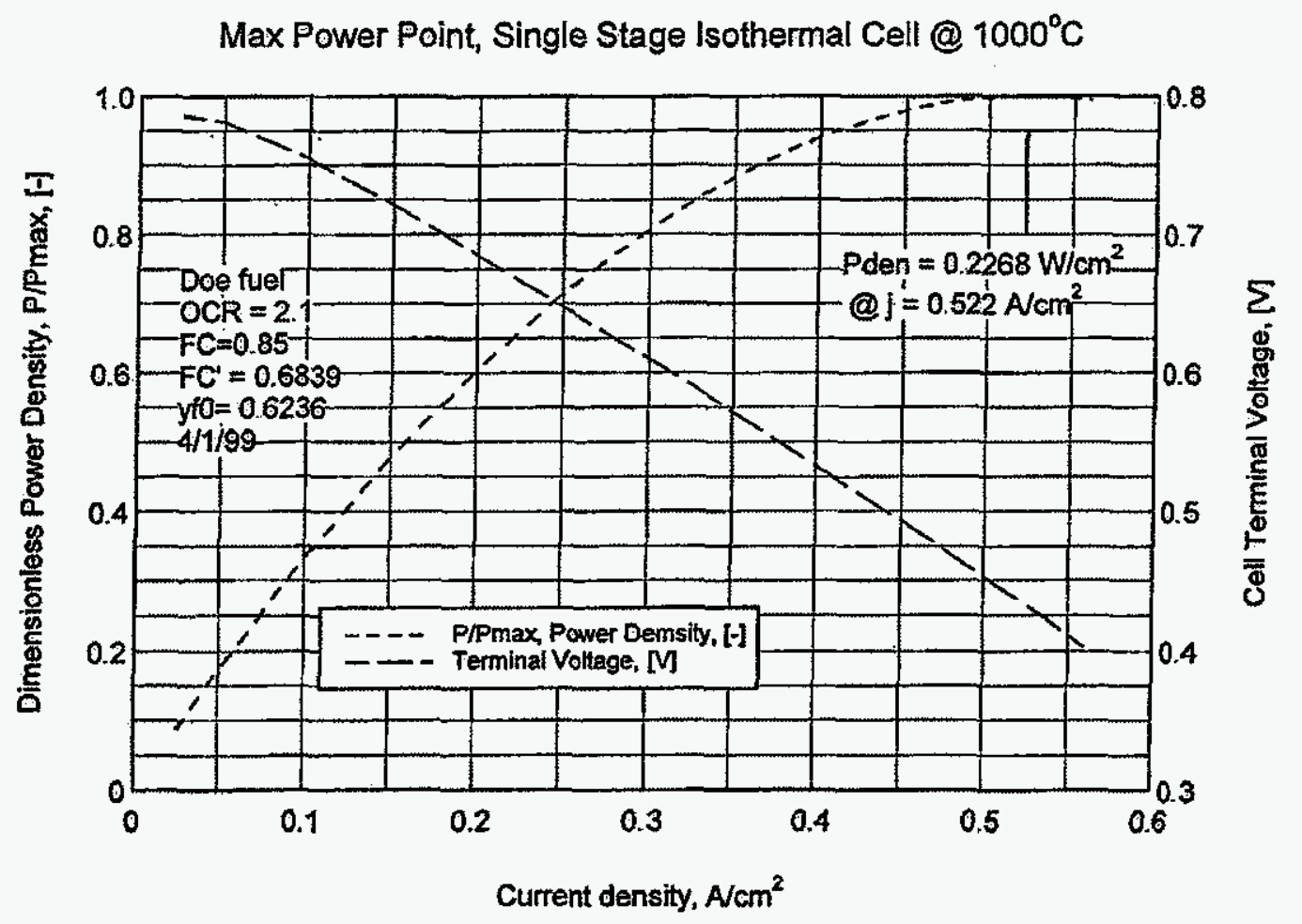

Figure A.1 - Power density and terminal voltage for a single stage cell. 


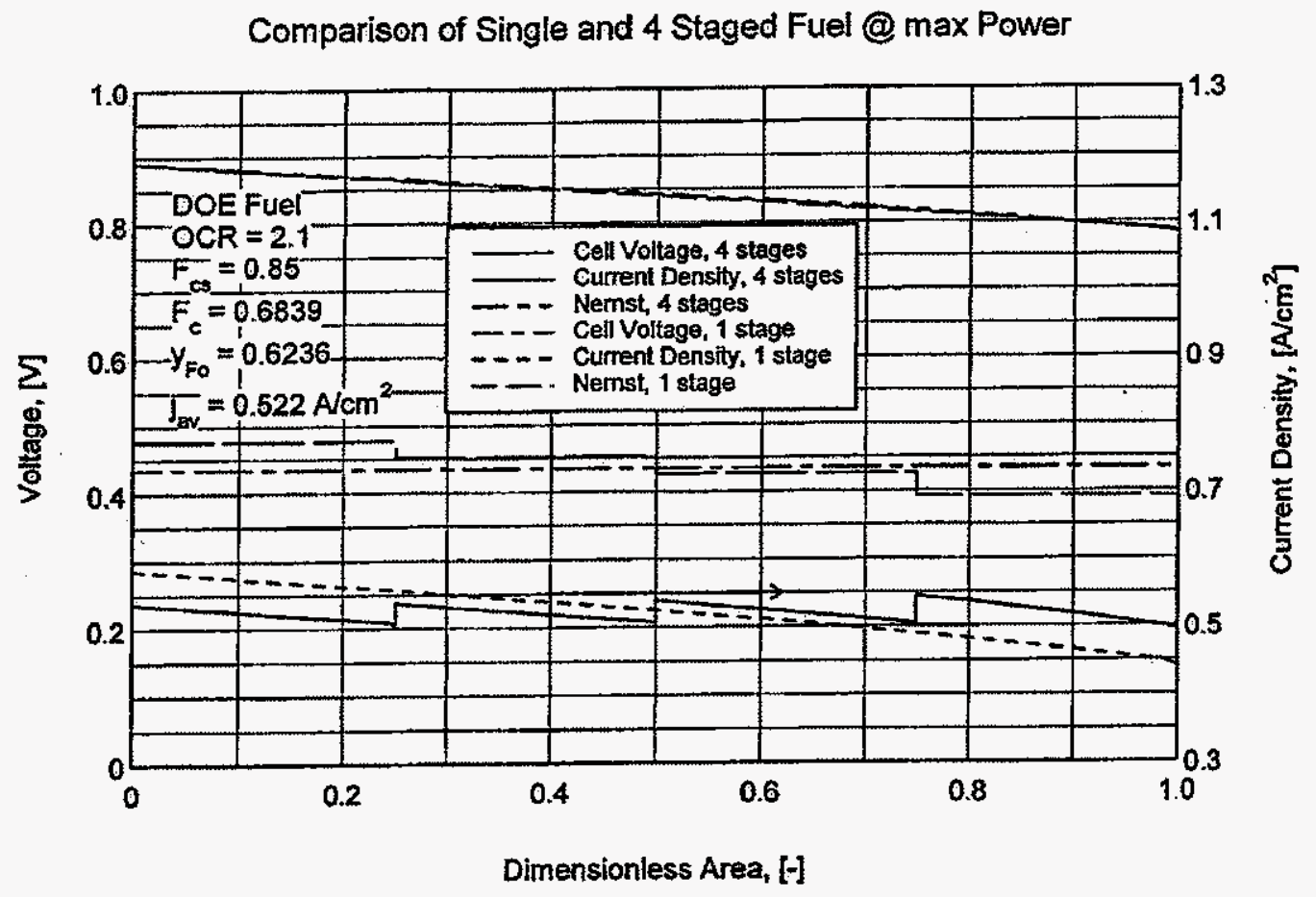

Figure A.2 - Emf and current density distributions in a 4 staged fuel cell. 


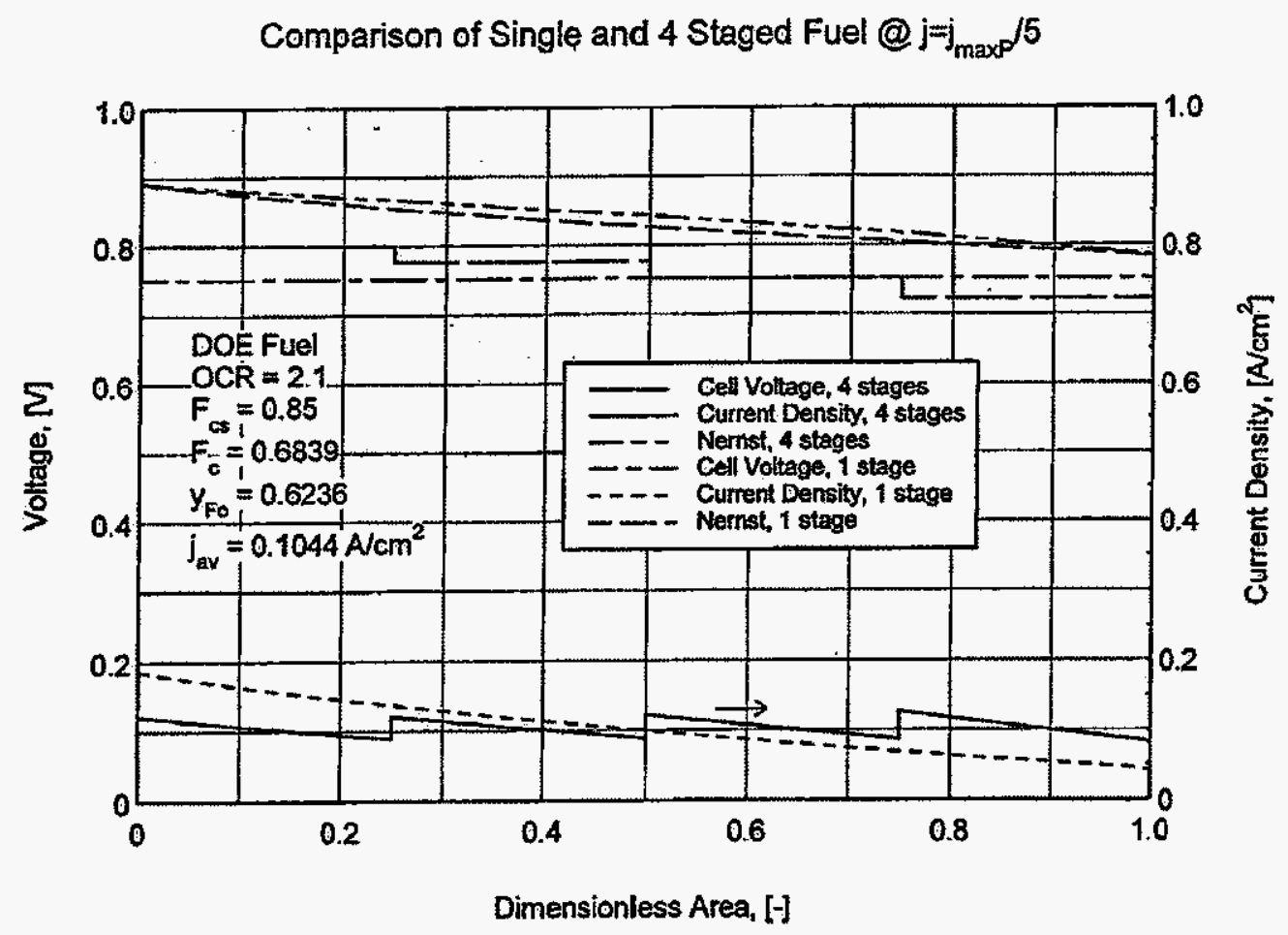

Figure A.3 - Emf and current density for single and 4 staged cell. 


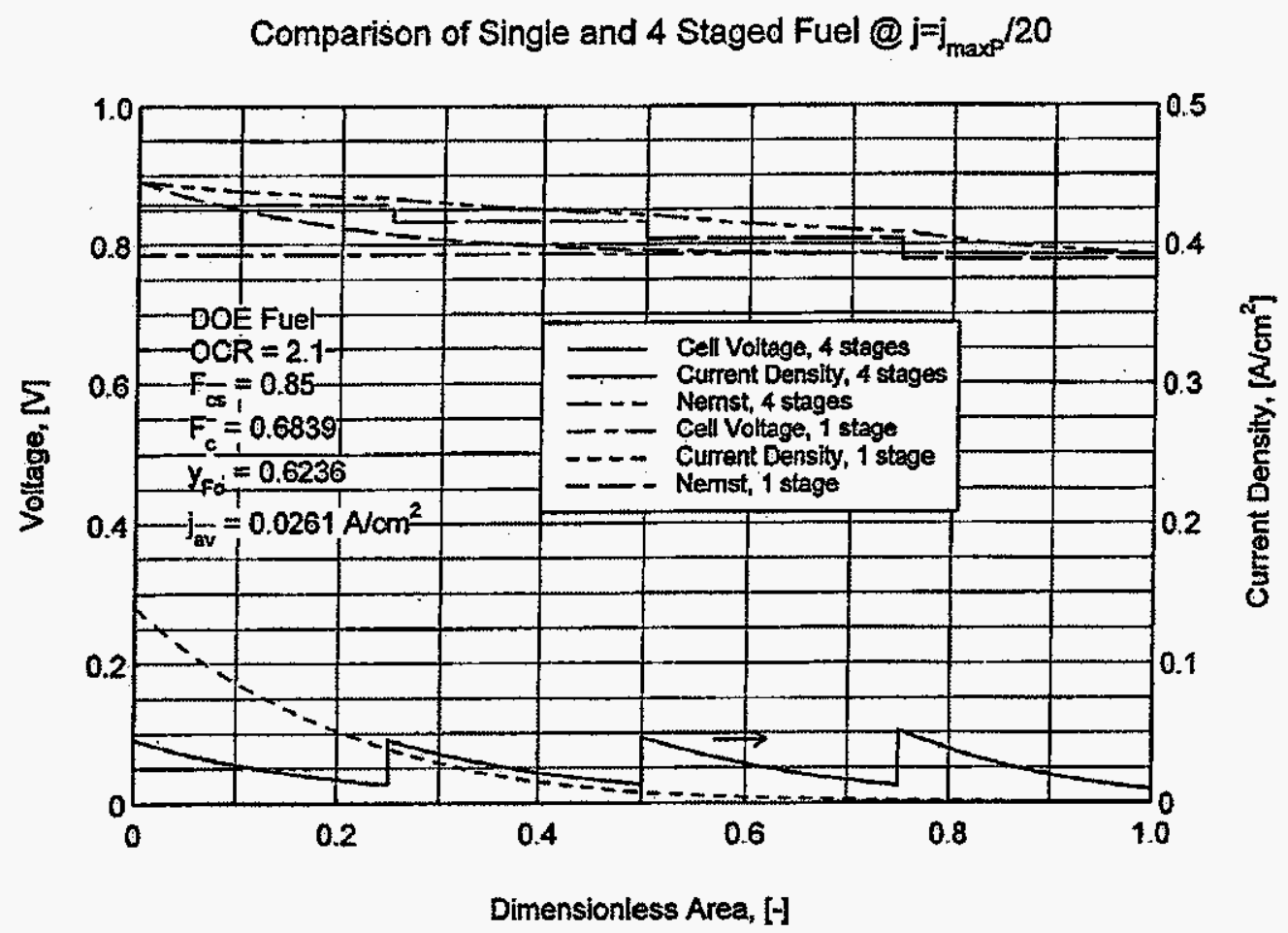

Figure A.4 - Emf and current density for single and 4 staged cell. 
Comparison of Single and 4 Staged Fuel @ max Power

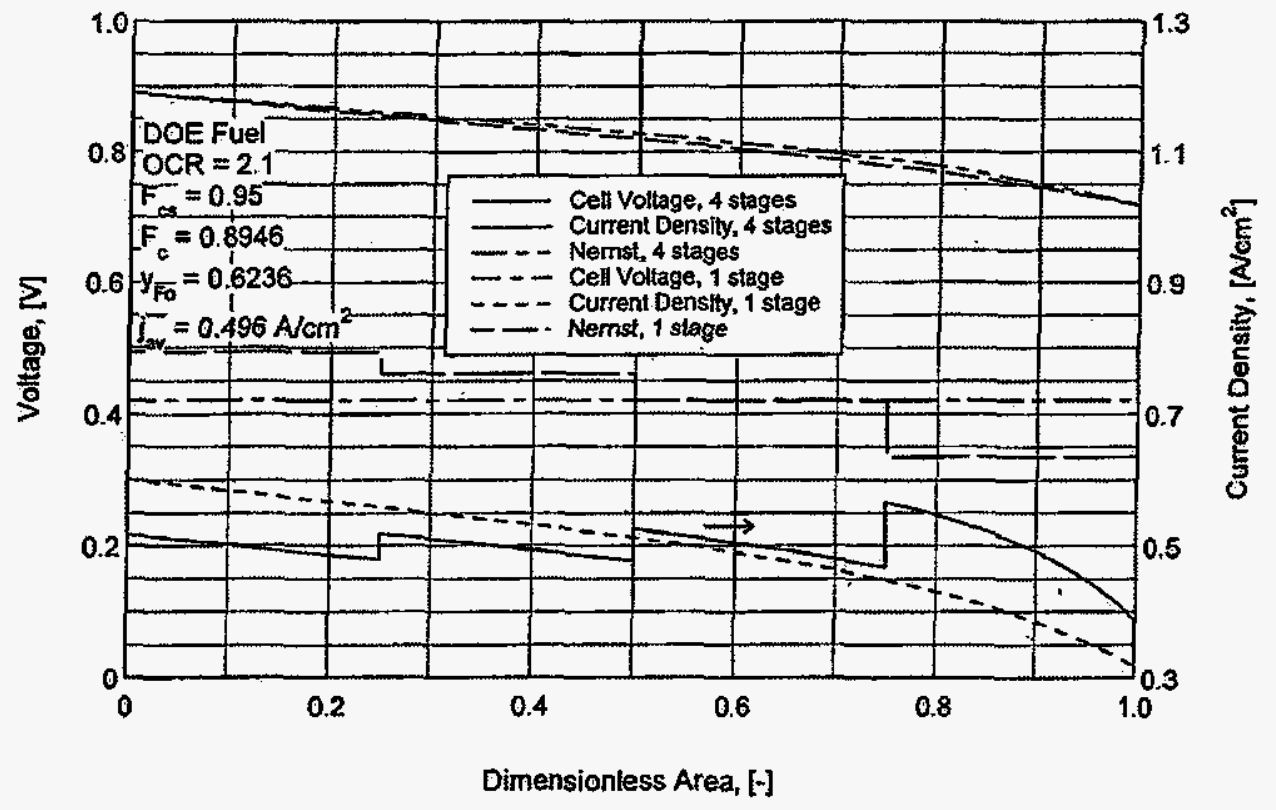

Figure A.5 - Emf and current density for single and 4 staged cell. 


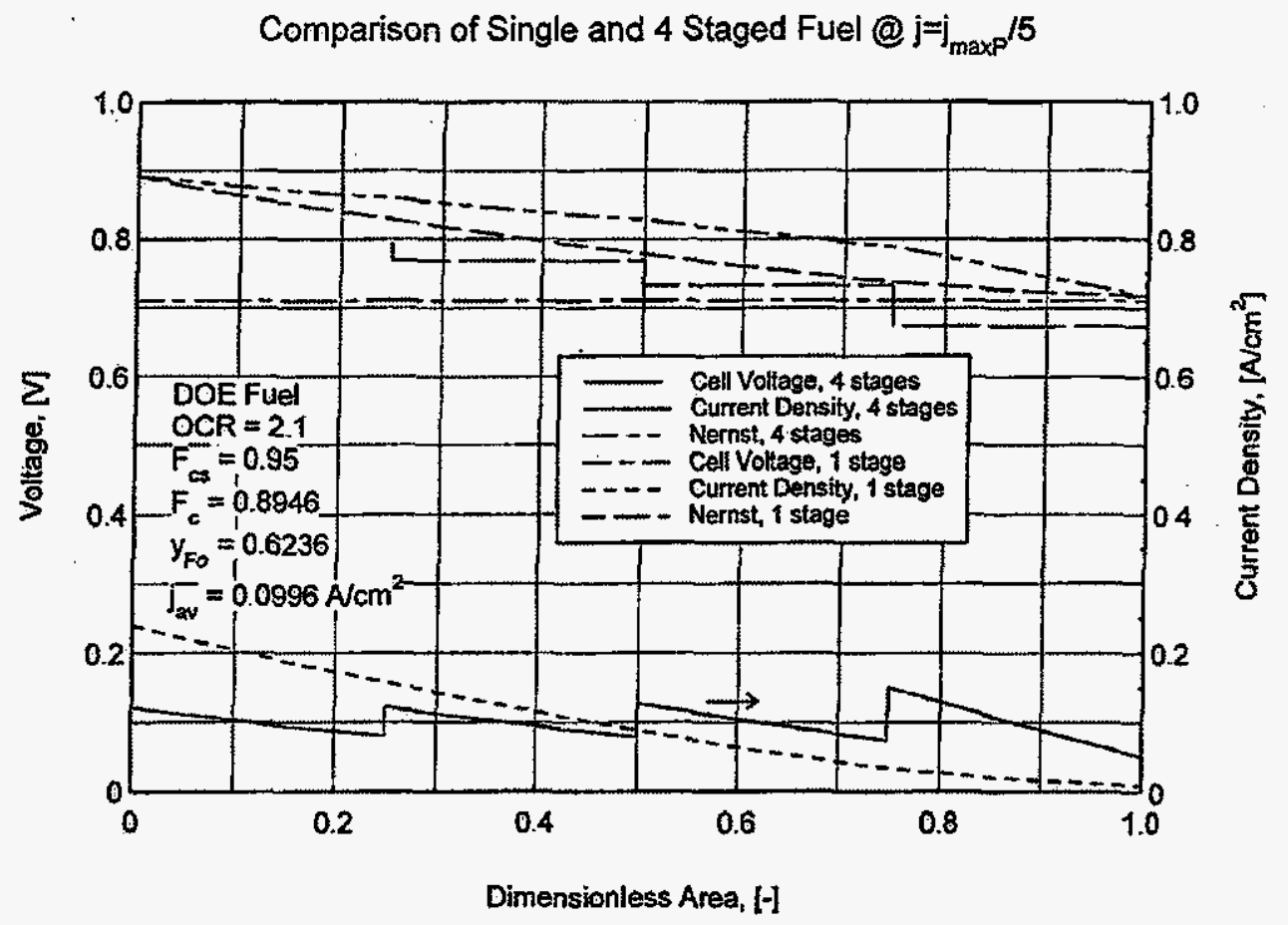

Figure A.6 - Emf and current density for single and 4 staged cell. 


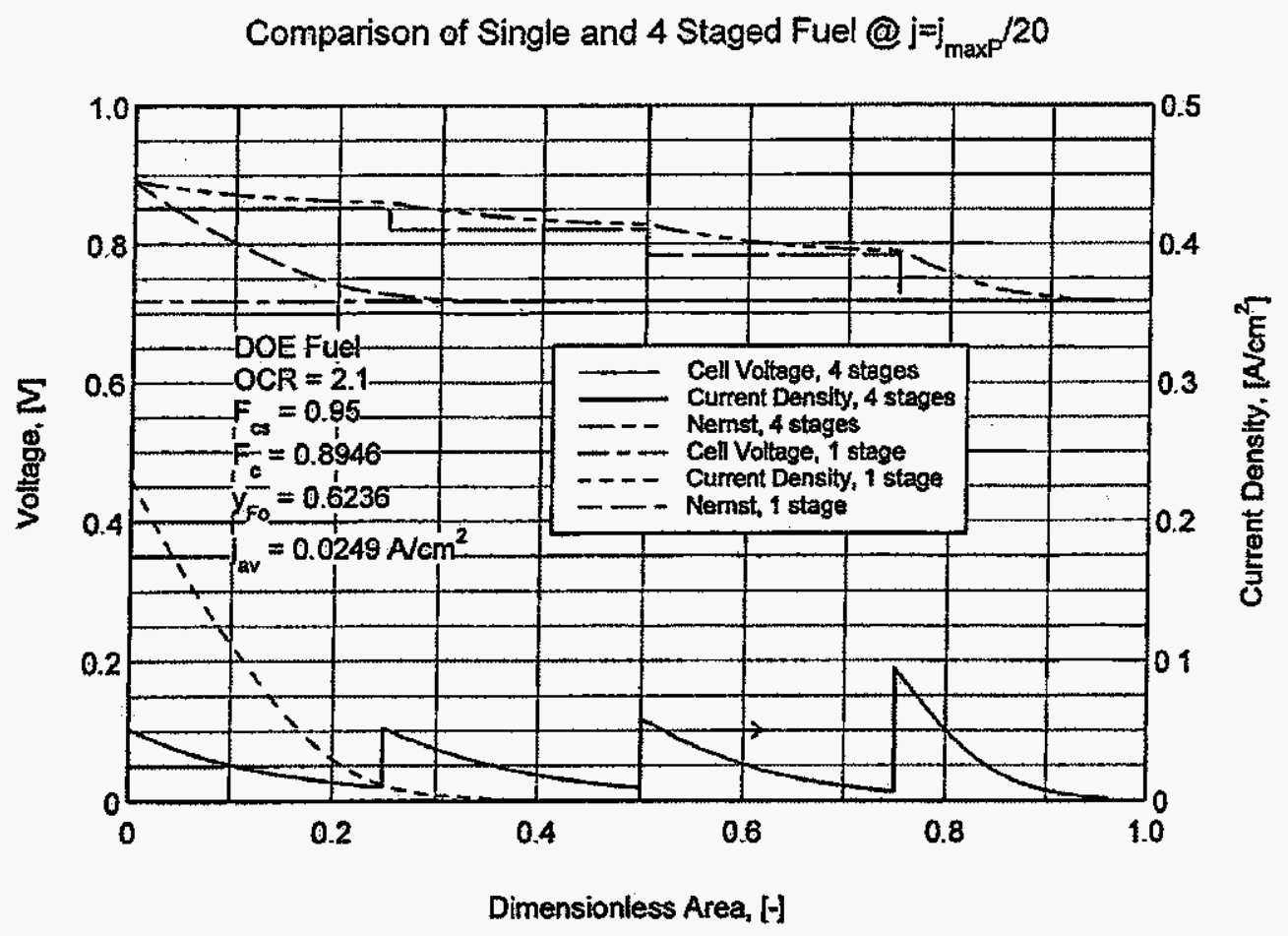

Figure A.7 - Emf and current density for single and 4 staged cell. 
Table A.1

Effect of Staging on Average Voltage or Power Density

\begin{tabular}{|c|c|c|c|}
\hline $\begin{array}{c}j_{\text {av, }} \\
{\left[\mathrm{A} / \mathrm{cm}^{2}\right]}\end{array}$ & $\begin{array}{c}F_{\mathrm{cs},} \\
{[-]}\end{array}$ & $\begin{array}{c}\mathrm{P}_{\mathrm{d}} \text { for } 1 \text { stage, } \\
{\left[\mathrm{W} / \mathrm{cm}^{2}\right]}\end{array}$ & $\begin{array}{c}\Delta \mathrm{P}_{\mathrm{d}} / \mathrm{P}_{\mathrm{d}} \text { for } 16 \text { stages, } \\
{[\%]}\end{array}$ \\
\hline 0.5220 & 0.85 & 0.2268 & 0.58 \\
\hline 0.1044 & 0.85 & 0.0785 & 1.53 \\
\hline 0.0261 & 0.85 & 0.0205 & 4.58 \\
\hline 0.4980 & 0.95 & 0.2099 & 1.15 \\
\hline 0.0996 & 0.95 & 0.0707 & 5.06 \\
\hline 0.0249 & 0.95 & 0.01786 & 11.87 \\
\hline
\end{tabular}


Relative Number of Cells Required for Fixed Output

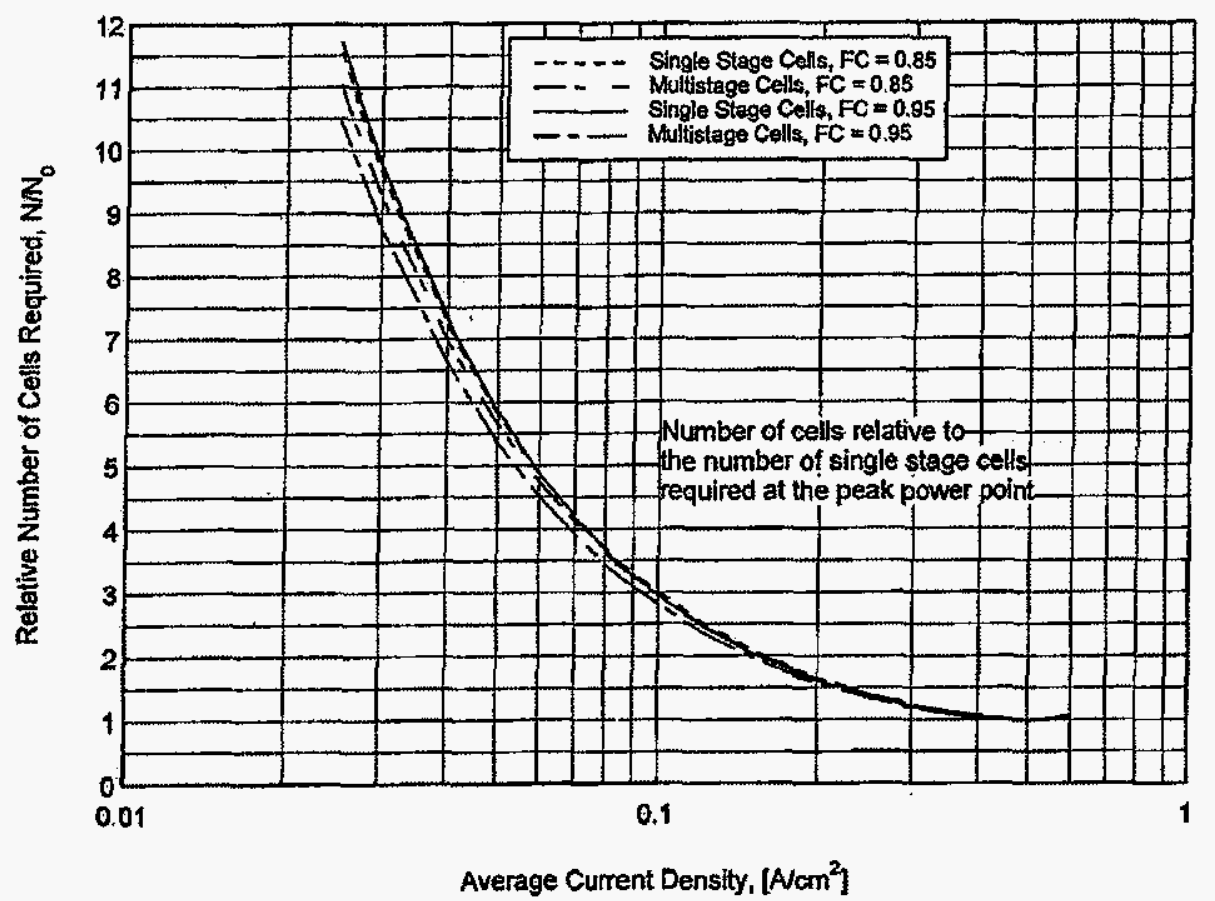

Average Current Density, $\left[\mathrm{Acm}^{2}\right]$

Figure A.8 - Relative number of cells required for fixed power output as a function of current density. 
Comparison of Increase in Power Output Due to Staging.

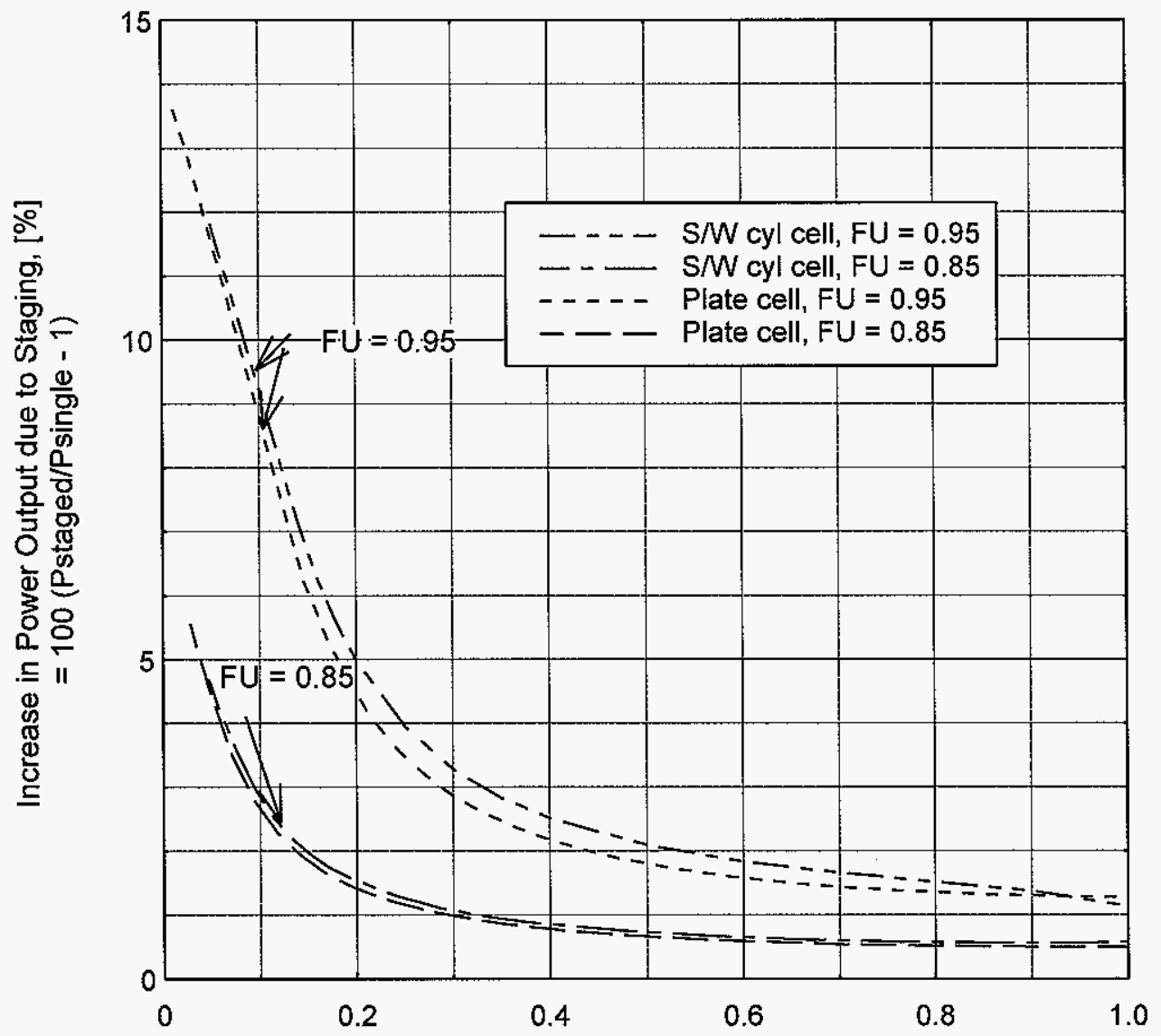

Normalized Current Density $=\mathrm{J} /(\mathrm{J}$ at max Power Density $),[-]$

Figure A.9 - Increase in the power output due to staging for planar and cylindrical cells vs. dimensionless current density. 
Once Through Flow Compared with Recirculation Fuel Flow, Staged Planar Cells

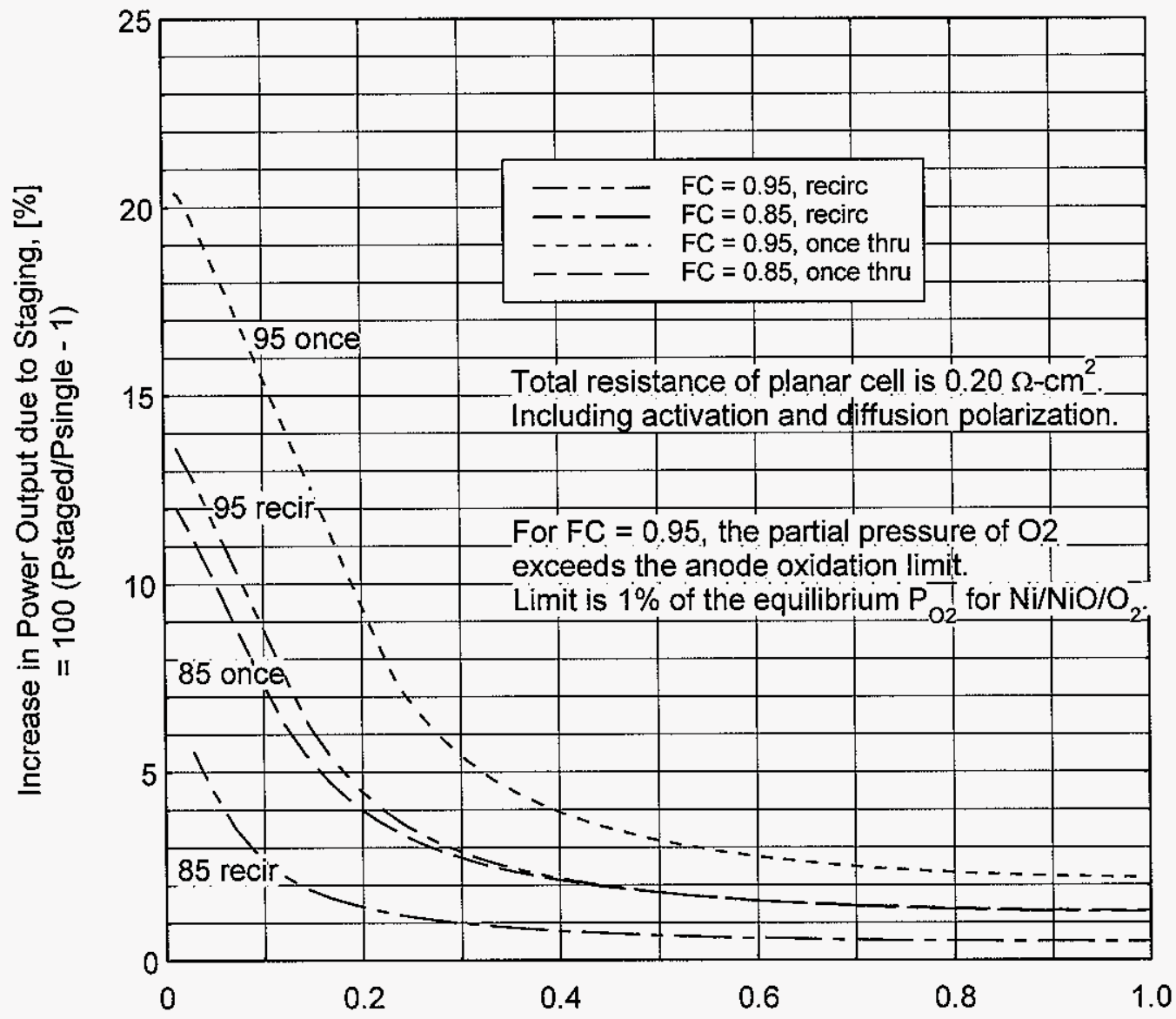

Reduced Current Density, $=\mathrm{J} /(\mathrm{J}$ at max Power Density), [-]

Figure A.10 - Comparison of effect of once through and recirculation fuel flow on the benefits of cell staging. 